\title{
Christian Education in the 21st Century: Renewing a Transformational Vision
}

Gabriel J. Pethtel

Cedarville University

Follow this and additional works at: http://digitalcommons.cedarville.edu/education theses

Part of the Education Commons

\section{Recommended Citation}

Pethtel, Gabriel J., "Christian Education in the 21st Century: Renewing a Transformational Vision" (2011). Master of Education

Research Theses. 38.

http://digitalcommons.cedarville.edu/education_theses/38 


\section{CHRISTIAN EDUCATION IN THE $21^{\text {ST }}$ CENTURY: RENEWING A \\ TRANSFORMATIONAL VISION}
A thesis project submitted in partial fulfillment of the requirements for the degree of Master of Education

By

Gabriel J. Pethtel

B.S. Secondary Education, Ball State University, 1997

2011

Cedarville University 


\section{CEDARVILLE UNIVERSITY}

\section{SCHOOL OF GRADUATE STUDIES}

August 8, 2011

I HEREBY RECOMMEND THAT THE THESIS PREPARED UNDER MY SUPERVISION BY Andrea James Webb ENTITLED Career College Students' Perceptions of Portfolios and Their Influence in the Hiring Process BE ACCEPTED IN PARTIAL FULFILLMENT OF THE REQUTREMENTS FOR THE DEGREE OF Master of Education.

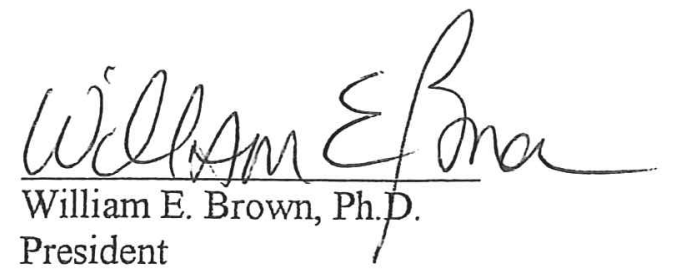

President

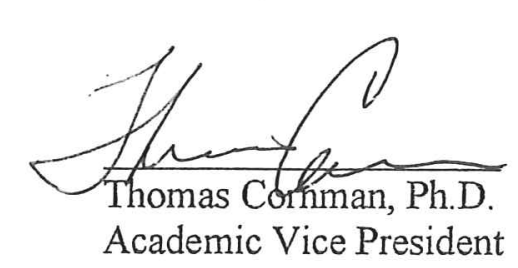

$\frac{\text { MersD. MeClan }}{\text { Mark D. McClain. Ph.D. }}$

Associate Academic Vice President

College of Professions
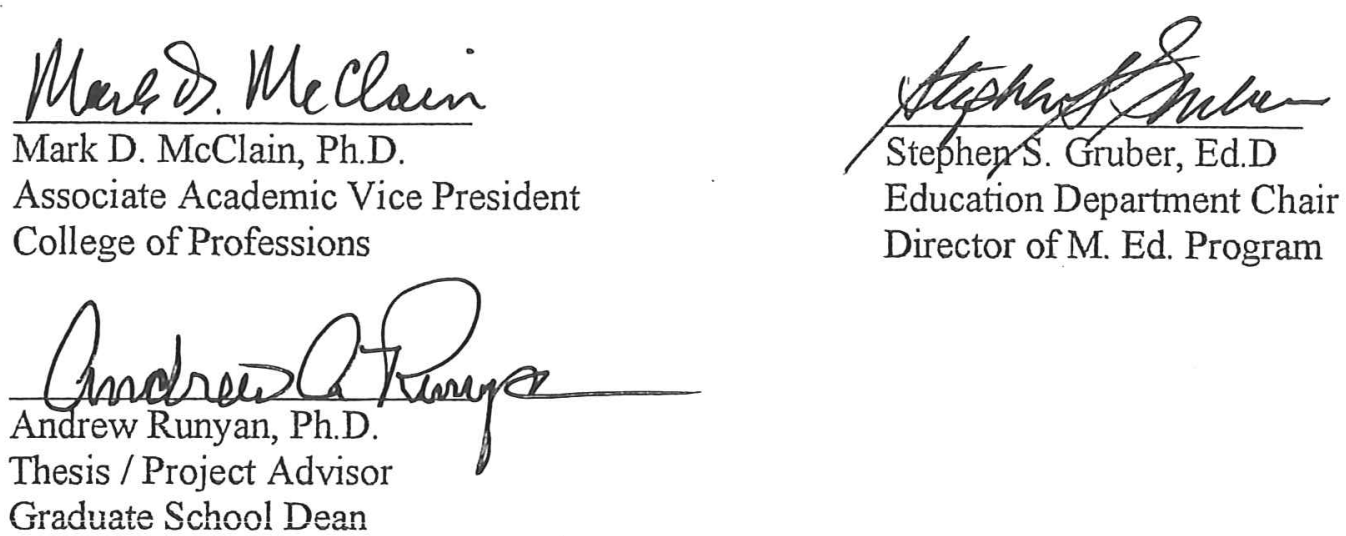


\section{Dedication}

Gabriel J. Pethtel would like to thank those who contributed to the numerous costs, various tasks, and countless hours that went into creating this Master's thesis on Christian education in the $21^{\text {st }}$ century.

Thanks to Dayton Christian Schools and Lititz Christian School for providing funding and opportunity to pursue graduate education leading to this thesis research.

Thanks to Jenna Meyers, at Millersville University for detailed assistance with transcription and proofreading of the various drafts of this paper.

Thanks to Dr. Tim Heaton for providing friendship and academic mentorship throughout the last two years. Your willingness to push me to "become believable" has made a lasting impression on my desire to pursue continued education and learning as a Christian school administrator.

Thanks to my grandmother, Lura Pethtel, for providing encouragement and insights to write this research.

Thanks to my mother and father, Scott and Cindy Pethtel for encouraging me to go after my dreams.

Thanks to my loving wife, Dana Pethtel, and my children, Logan, Caleb, and Emma for keeping the home fires burning while I was away researching and writing. I love you all very much! 


\begin{abstract}
Pethtel, Gabriel J. M.Ed., Education Department, Cedarville University, 2011. Christian Education in the $21^{\text {st }}$ Century: Renewing a Transformational Vision
\end{abstract}

The findings of this research include educational concepts synthesized from interviews with several contemporary Christian school leaders including, D. Bruce Lockerbie, Jeff Woodcock, Janet Lowrie Nason, Barret Mossbacker, Bob Gresh, Rick Bernhardt, Randy Ross, Chirs Cleveland, Dr. Jane Duffey, Dr. John Foreman, and Dr. Marck Eckel. The voices of these educators are combined with literary points made by foundational Christian school leaders in years past, such as Frank E. Gaebelein, Roy W. Lowrie, Roussas J. Rushdoony, Cornelius Van Til, and Gene Garrick, to renew a transformational vision for Christian education in the $21^{\text {st }}$ century. Research findings promote a call to create true community between teachers, administrators and students in the modern Christian school. The promotion of a more relational approach to learning and discipleship is emphasized. An appeal for critical thinking is tied to the idea that modern Christian educators must embrace the age of information technology available to their students. A qualitative data analysis was performed on the transcription of the interviews conducted to bring out several of the similarities in response by those Christian educators interviewed. The research conducted was done in partial fulfillment of a Masters level degree program. 


\section{TABLE OF CONTENTS}

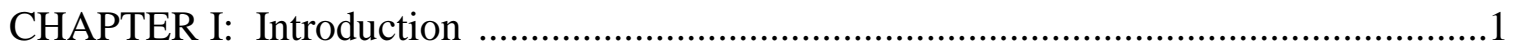

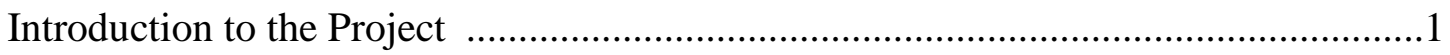

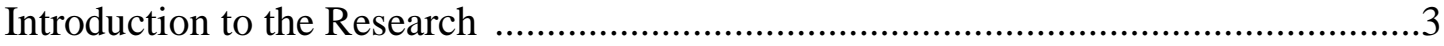

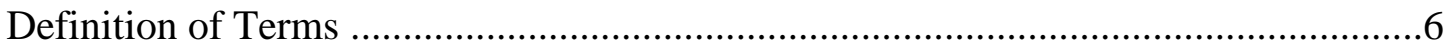

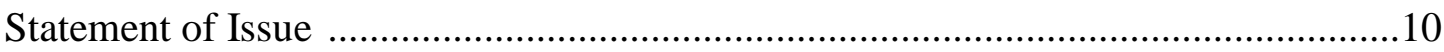

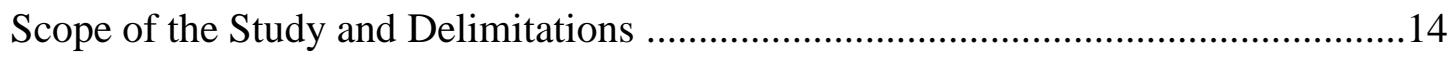

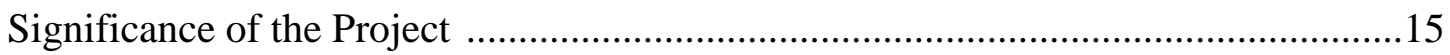

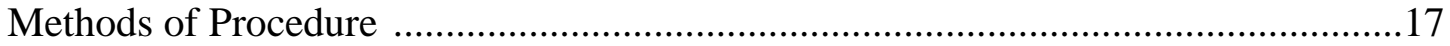

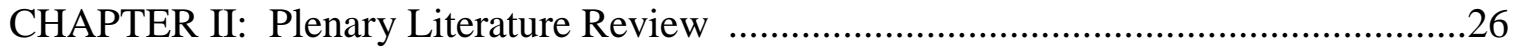

Overview of Christian Education in the $21^{\text {st }}$ Century …...........................................26

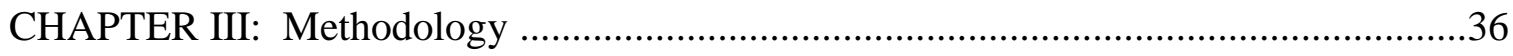

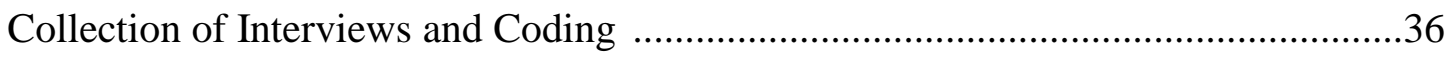

CHAPTER IV: Discussion and Implications ...........................................................51

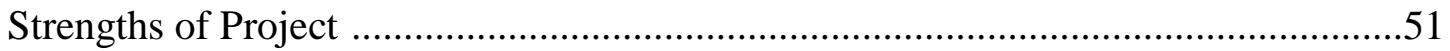

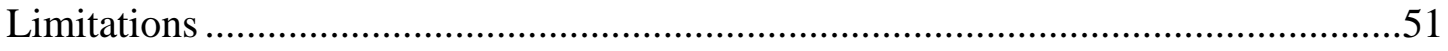

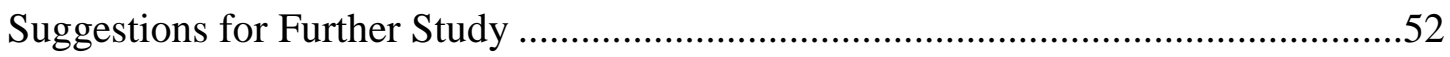

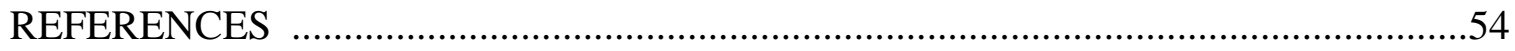

APPENDIX

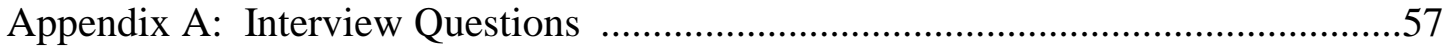

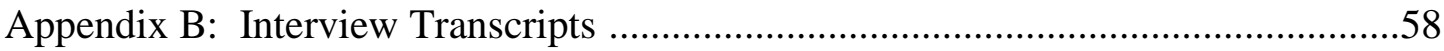




\section{Chapter 1}

Introduction

\section{Introduction to the Project}

Renewing the call for Christian education in the $21^{\text {st }}$ century must be done in a manner that not only respects historic foundations of this enterprise, but also recognizes the unique needs of the $21^{\text {st }}$ century student. The modern research that has been conducted to enhance educational approaches to better reach students with relevant learning and skills has brought about a change in the theory of educational practices. The truly Christian educator must understand and implement all best practices discovered through research and also believe that modern educational research does not change the foundational biblical principles which must always serve as the bedrock of all learning and truth. In many regards, truly Christian teaching and learning places a lofty demand on teacher and student alike. The Christian teacher must not only prepare the standard lesson plan in their subject area, but must also possess and refine a biblical understanding of each lesson they prepare so as to create a biblical framework for all that goes on in the Christian school. Christian philosophy asserts that since God created all things and they all now exist by his power and for his pleasure (Revelation 4:11), there is a unity which gives meaning to all the diverse and seemingly contradictory parts of life (Lowrie, Garrick 1984, 13). Some have referred to this unity as correlation, some refer to it as integration, and some refer to the unity between faith and learning as a matter of creating biblical frameworks for learning. Closer examinations of these terms and a desire to understand the philosophy by which they are being used may simply lead one to understand each as useful and almost 
interchangeable depending on the desired aim of the person using the term. Essentially, each term, correlation, integration, and framework, provides an excellent conceptual guide for the necessary core of Christian education. Christian education is primarily the belief that all learning and truth is ultimately from God and must be understood through a close understanding of the Bible.

Interviews with eleven experienced professionals in Christian education provided their responses to questions that will tell us about how they have developed or hope to develop the mission and vision for Christian education in the $21^{\text {st }}$ century in their school or professional area of influence in the Christian education community. The purpose of this research project is to provide the responses of these individuals and then compare their thoughts with several historical as well as more recent works highlighting the foundations of Christian education. The goal has two parts. The first part is to remind Christian educators in the $21^{\text {st }}$ century about the clear and unchanging biblical mission and vision for Christian education that has been given down though the ages as related through Deuteronomy chapter 6, "Hear, O Israel: The LORD our God, the LORD is one. Love the LORD your God with all your heart and with all your soul and with all your strength. These commandments that I give you today are to be on your hearts. Impress them on your children. Talk about them when you sit at home and when you walk along the road, when you lie down and when you get up. Tie them as symbols on your hands and bind them on your foreheads. Write them on the doorframes of your houses and on your gates.” The second part is to present relevant input from contemporary Christian educators as well as provide insights from the past and present that fit the real needs of modern students. It is also a hopeful calling for others to join in this vision for Christian education in the $21^{\text {st }}$ century and bring renewal to the transformational vision for Christian education already presented by several 
founding fathers of $20^{\text {th }}$ century Christian education. It is a biblical and philosophical vision for education which seems to have been in short supply in the last decade.

\section{Introduction to the Research}

Firstly, in order for Christian education to thrive in the $21^{\text {st }}$ century, a greater amount of emphasis must be placed on understanding the foundations on which Christian education was built and then a renewed mission and vision must be communicated to all stakeholders including the school board, donors, administrators, parents, students, and teachers. To formulate a more complete Christian educational philosophy for the modern era, not only were current Christian education professionals interviewed, but also many past visionaries such as Roy W. Lowrie, Jr., Frank E. Gaebelein, Albert E. Greene, H. Gene Garrick, Claude E. Schindler, Cornelius Van Til, Norman De Jong, Carl F.H. Henry, and Rousas J. Rushdoony, were considered through literature they had written earlier promoting a biblical vision for Christian education in the $20^{\text {th }}$ century. Together with the transcript responses of the eleven subjects interviewed for this project, a great amount of evidence exists that the transformational vision for Christian education in the $21^{\text {st }}$ century is alive but must continue to be renewed so that it may continue for generations to come. It should continue to be the place of the Christian school parent, teacher, and administrator to promote a form of schooling that focuses on the revealed truth of God in Christ. Carl F.H. Henry stated, "The drift of $20^{\text {th }}$ century learning can be succinctly summarized in one statement: Instead of recognizing Yahweh as the source and stipulator of truth and the good, contemporary thought reduces all reality to impersonal processes and events, and insists that man himself creatively imposes upon the cosmos and upon history the only values they will ever bear" (1984, 
84). Therefore, a renewed call to think Christianly about education is necessary here at the start of a new century. A framework for Christian schooling must be introduced and promoted so that existing Christian schools may thrive and a new Christian school might develop to reach more children with a unique mission and vision.

Secondly, the Bible, history, theology, philosophy, and the needs of modern students and families must be considered when developing the mission and vision of the Christian school. Areas such as the integration of technology have become highly important and must continue to be applied effectively in developing the skills of the modern student. Also, the integration of the Bible into all subject areas must be as effective as ever to promote in each student a complete understanding of the patterns of God's truth and encourage a heart commitment to these truths. Dr. Frank E. Gaebelein reiterated the ancient words of St. Augustine in stating, "All truth is God's truth”. Norman De Jong stated in his Philosophy of Christian Education: A Christian Approach, "In order to carry out this educational mandate in the most efficient and effective manner, parents have cooperatively joined to form school societies and establish schools. Once these societies are formed, the "formal" educational program becomes a cooperative effort and ceases to be an individual matter" $(1977,19)$.

Over the past few decades, secular approaches to education have been slowly assimilated into the Christian school mentality, and much of the original understanding of Christian education has been lost. The biblical vision for education stands in direct conflict with the principles of an educational system that promotes the modern vision of man as the center of all purposes for education. Humanist Manifesto I written in 1933 promoted its eighth aim to be that, "Religious humanism considers the complete realization of human personality to be the end of 
man's life and seeks its development and fulfillment in the here and now”. Since John Dewey, considered a father of $20^{\text {th }}$ century educational theory, signed this manifesto, we can safely say that the mission and vision coming from his prevalent educational theories does not line up with the theory or practice of Christian education. It is the Deweyian progressive vision for education that has come to dominate the philosophy and practice of education in the $21^{\text {st }}$ century. While there are obvious benefits to the use of techniques such as project based learning and group instruction, it must be strongly noted Dewey himself approached education from a strictly nonbiblical stand point. While the impact of progressive theory may have brought about an important concept in the understanding of human learning through doing rather than conceptualizing, the impact of seeing students as capable of learning on their own through such progressive techniques has had far reaching effects. Positive effects stem from group learning to project based learning techniques that have truly prepared students for the modern world in which they must live and work. Negative effects, from a biblical perspective, include the removal of the teacher from a position of authority in the classroom and the belief that the student holds the key to learning and progress with little emphasis on classroom or student discipline.

The philosophies of education implemented in a Christian school must consistently be examined before, during and after implementation. There is no part of school life and practice which is not affected by its philosophy of education (Garrick, 1984, p. 11). Here in the $21^{\text {st }}$ century, allies of Christian schooling have choices to make. They can continue to go on building without ever stopping to be reminded of the costs warned of by great leaders who have gone before; they can fail to cast a mission and vision that compels others to join with them in the effort to provide excellent and relevant Christian schooling; or they can pay attention to the well reasoned 
literature of the past and present and educate children from the vantage point that God is the creator and sustainer of life here and life hereafter.

\section{Definition of Terms}

Modernism - More specifically, the term describes the modernist movement, its set of cultural tendencies and array of associated cultural movements, originally arising from wide-scale and far-reaching changes to Western society in the late 19th and early 20th centuries. Modernism was a revolt against the conservative values of realism in the belief that the entirety of the earth and man could be fully understood through logic. It was a desire to understand the world through reason. The underlying assumption of early modernists was that the world is a reasonable place and that the reality that exists can not only be understood by the human mind, but that there is a system of fixed laws which undergird both reality and human thought at its best. Arguably the most paradigmatic motive of modernism is the rejection of tradition and its reprise, incorporation, rewriting, recapitulation, revision and parody in new forms. Modernism rejected the existence of a compassionate, all-powerful Creator God. Modernism desired to provide human beings with certain truth, truth that was beyond doubt, human understanding that mirrored reality as it existed. Such knowledge was believed to be objective and neutral, as was the scientific method itself. However, reason and science did not lead to utopia. The despair that was left led to postmodernism (Knight, 1998, 82-83).

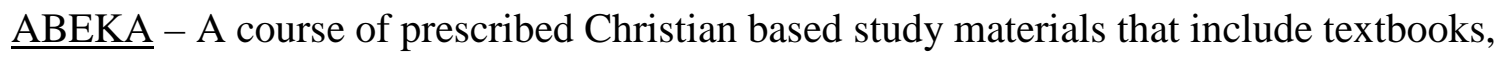
curriculum, lessons pans, tests, quizzes, suggested projects and online or DVD/CD Rom learning 
materials. ABEKA is an educational outreach of Pensacola Christian College. (http://www.abekaacademy.org/)

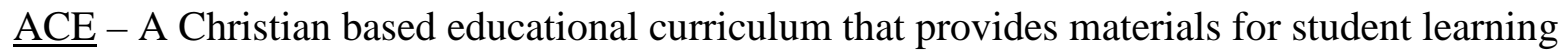
which allow the student to move through "Paces" to acquire mastery knowledge of each component learned in the curriculum. This curriculum is designed to be accomplished by the student with little to no adult guidance. (http://www.aceministries.com/)

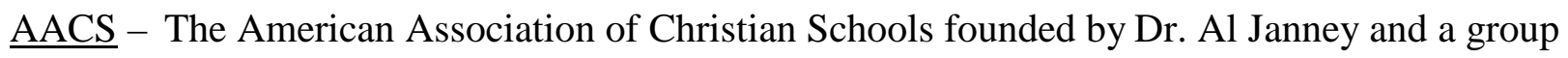
of his peers in August, 1972, in Miami, Florida, to form a non-profit corporation. Dr. Janney then served from 1972 until 1992 as the Association's first president. At the first recorded AACS board meeting, held in Dallas, Texas, on November 30, 1972, Dr. Janney set forth the question: "Where is the separatist organization, on a national level, that will champion our cause?" Thus was the need for AACS clearly voiced and firmly established. AACS became a national outgrowth of its predecessor, the Florida Association of Christian Schools (FACS), which had been founded in 1967 to help its member schools in Florida. Having experienced the hurdles and opposition being thrown up against the fledgling but mushrooming Christian school movement in the United States, Dr. Janney began traveling to other states in an effort to help them organize Christian school associations. AACS sought to provide leadership to the newly-formed state associations by providing legislative protection and high-quality educational programs and services (http://www.aacs.org/history/).

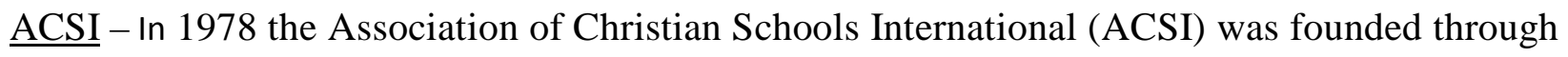
a merger of three associations: The National Christian School Education Association; The Ohio Association of Christian Schools; and the Western Association of Christian Schools. 
Soon after the new association formed, several other Christian school associations joined ACSI: The Southeast Association of Christian Schools; the Association of Teachers of Christian Schools (Midwest); the Great Plains Association of Christian Schools; and the Texas Association of Christian Schools. ACSI was first headquartered in La Habra, California, the former office of the California Association of Christian Schools. As the organization grew, larger office and warehouse facilities were needed. Thus, ACSI moved to its new international headquarters in Colorado Springs, Colorado, in 1994. Today, in addition to their headquarters facility, ACSI has 26 regional offices worldwide. Currently ACSI serves over 5,900 member schools in approximately 106 countries with an enrollment of more than 1.4 million students. Programs and services are designed to assist Christian schools at every grade level including early education and higher education. ACSI is a 501(c) (3) nonprofit organization governed by a 36-member Executive Board elected by member schools.

(http://www.acsi.org/tabid/535/itemid/76/default.aspx)

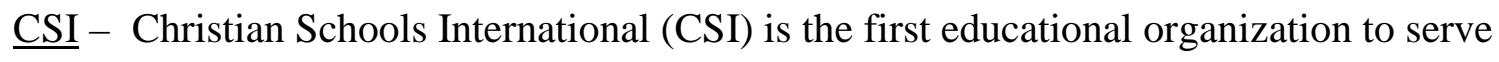
Christian schools. Founded in 1920, they have more than eight decades of experience serving Christian schools throughout North America and the world. Their view of the world is firmly rooted in the Reformed tradition of Christian theology. This world-engaging ethos permeates their philosophy of Christian education and shapes everything they do as Christians and as educators. Christian Schools International is committed to the idea of Christian education. We provide the support for thousands of Christian school teachers and administrators the world over. (http://www.csionline.org/about/) 
Fundamentalism - A movement among protestant Christians in the $20^{\text {th }}$ century that stressed the importance of a literal interpretation of the Bible as essential to the Christian life. (http://www.merriam-webster.com/dictionary/fundamentalism)

Worldview - The meaning of the term worldview (also world-view, world view, and German Weltanschauung) seems self-evident: an intellectual perspective on the world or universe. Indeed, the 1989 edition of the Oxford English Dictionary defines world-view as a "... contemplation of the world, [a] view of life ..." The OED defines Weltanschauung (literally, a perception of the world) as "... [a] particular philosophy of life; a concept of the world held by an individual or a group ..." In Types and Problems of Philosophy, Hunter Mead defines Weltanschauung as [a]n all-inclusive world-view or outlook. A somewhat poetic term to indicate either an articulated system of philosophy or a more or less unconscious attitude toward life and the world ... In his article on the philosopher Wilhelm Dilthy in The Encyclopedia of Philosophy, H.P. Rickman writes [t]here is in mankind a persistent tendency to achieve a comprehensive interpretation, a Weltanschauung, or philosophy, in which a picture of reality is combined with a sense of its meaning and value and with principles of action. (http://web.engr.oregonstate.edu/ funkk/Personal/worldview.html) 
Statement of Issue

Christian school administrators know that one of the best ways to ensure consistency is to promote biblical understanding of the nature of human beings and its implications for education. Dr. Gene Garrick, former headmaster of Norfolk Christian Schools in Virginia and a founding member of the ACSI board, would annually conclude his review of biblical understanding of the nature of human beings and its implications for education by referring to a quotation by Joseph Wood Krutch (Garrick 1991, 23): "Education is that which experience has shown will lead (the student) to a true understanding of his own nature, his own needs and his own wants. We could say the ideal of education is not conformity, not acculturation, but the full development of human nature's potentialities. All students have gifts. Some are promoted as more important than others depending upon the culture one lives within. The specific bent of the student and the teacher varies based upon the God given gifts that are inherent to the individual. Therefore, the aim of any education, be it secular or religious in nature, should be to bring about a more complete development of the gifts of each student”.

In order to accomplish this type of focus, the needs of the $21^{\text {st }}$ century student must be considered. No teacher can afford to deny the needs of the student in this age. Due to the recent rash of Christian school closings in the early part of the $21^{\text {st }}$ century, it may be said that it is even more imperative that Christian educators pay attention to the needs of the modern student as they prepare lessons and consider larger goals in the Christian school. As Christian educators know, the balance between caring for the specific learning needs of the modern student and promoting the reasons behind the operation of the Christian school is nuanced. You have the powerful vision of Cornelius Van Til in his Essays on Christian Education (1974, 27-28) that if you say 
you are involved in the struggle between Christ and Satan in the area of family and in the church, but not in the school, you are deceiving yourself. You cannot expect to train intelligent, wellinformed soldiers of the cross of Christ unless Christ is held up before them as Lord of culture as well as Lord of religion.

It will not be simple to construct a renewed call to the foundations of Christian education for the $21^{\text {st }}$ century. We live in a highly nuanced society that is far different from that of the founders of Christian education in the United States. Modern students have grown up with the internet as a source of information. Technology has developed as has the need to understand and acculturate new forms of ethical and moral understanding to the children who use these technologies. In addition, the seeming dissolution of the nuclear family has posed a threat to the very foundation of modern society as an increasing number of children are raised without the security and stability of a dual parent home. These few factors alone can create a difficult picture, but the addition of a highly competitive global economy presents a level of anxiety not previously experienced by students in the United States.

Developing an alternative Christian consciousness among teachers and students in today's secularized society is not the work of one meeting, one memo, or one moment. Our thinking is thoroughly adulterated by Enlightenment concepts. It is as polluted as the most victimized parts of our physical environment. Genuine Christian thinking, the foundation of a Christian mind, is unintelligible to those who control the public media. Christian living, the practical outworking of the Christian mind, is more a wistful goal than a practiced reality among the Lord's people (Greene vii). A significant amount of planning, preparation, and hard work 
combined with a serious commitment to prayer will be required to bring the renewed call to $21^{\text {st }}$ century Christian education to life.

A significant issue brought about by technology is that of critical thinking. We live in an era where hand held media devices such as smart phones and iPads are the constant companions of nearly every student. As Dr. Barret Mosbacker stated in his interview for this project, "Students have literally in their pocket access to a universal world of information. They can access information within minutes, so I think the classroom needs to focus a bit less on providing information and a whole lot more on how to access, analyze, and assess that information, and a whole lot more on the issue of critical thinking” (B. Mosbacker, personal communication, March 31, 2011). The implications of community based learning, technology, and the call to think critically are so evident within the collected interviews for this thesis that an entire research project could be prepared on this unique collection of information alone. Christian schools must continually focus on the issue of critical thinking. Since students and teachers can spend much less time accessing information than in years past, there can be more emphasis placed on the application of that information to areas of significance.

Another significant issue is that of relationship. Students in the $21^{\text {st }}$ century seem to need a great deal of security in the notion that they are relationally well connected to those instructing them. The comments of numerous Christian educators interviewed for this research included key words such as collaboration, small groups, community, global village, and interpersonal relationship skills. These words show the direction of serious thought given by these subjects as it relates to the perceived need for greater relationship between teachers and students in the modern school. Dr. Jane Duffey of Norfolk Christian schools stated, "We are part of a 
community, and so we must understand what community life means and of course, that has changed so much in this $21^{\text {st }}$ century because we now speak of the Global Village and as Christians we talk about being ambassadors to the world” (J. Duffey, personal communication, April 6, 2011).

Dr. Janet Lowrie Nason discussed the broken nature of many modern homes in her interview for this project. She stated, “Students believe in relationships and it's so important to have relational teachers in the classroom that validate individuals and are concerned about individual students. This generation is relational in a way that has never been before, so traditional methodologies of education are not cutting it” (J. Lowrie Nason, personal interview, March 31, 2011). Nason as well as Dr. Barret Mosbacker, Head of Briarwood Christian Schools, and Jeff Woodcock, Head of Oaks Christian school all agreed that relationships were of utmost importance to this generation of students and went on to discuss the implications that this also has on the integration of learning strategies as well as technology integration in the $21^{\text {st }}$ century Christian school.

As the scope of our perspective on life and learning has changed from the $20^{\text {th }}$ to the $21^{\text {st }}$ century, so we must seek to renew our curricular vision to fit the demands of this century in Christian education. Rather than relying simply on the foundations of the historical Christian school movement, the modern Christian educational movement must acknowledge not only the existence of altered methods of information acquisition but also rapidly changing family structures and advanced systems of information delivery. These realities demand educational acknowledgment and credence in the Christian school curricula and more directly in the day to day teaching strategies used in each classroom. The modern Christian school must readily assess 
this confluence of events in the modern lives of the students and begin to synthesize a plan of curricular, co-curricular, and classroom action. The $21^{\text {st }}$ century Christian school must be a place where all of the necessary components of modern life are woven together with the unique calling of the foundational Christian school movement to create a renewed vision for Christian education in the $21^{\text {st }}$ century.

Scope and Study of Delimitations

This study was conducted as a qualitative data analysis (Caelli, Ray \& Mill, 2003). Eleven Christian education professionals were interviewed using a series of 14 questions developed with a perceived ability to bring about in depth responses to a few foundational needs of Christian education in the $21^{\text {st }}$ Century. This method allowed for a more eclectic approach to data collection and analysis. The participants in the study ranged in age, professional experience, and location of their professional position. All participants had a demonstrated commitment to Christian schooling based on their current position of leadership or number of years served in Christian schooling. Interview sessions were conducted with each participant in the form of digitally recorded phone or face-to-face interviews. One subject chose to type his response to the questions and email them when completed. Once interviews of approximately 45 to 60 minutes in length were taken with all but the one participant who chose to type his response, the recorded sessions were transcribed. Upon transcription, interviews were coded using a process of qualitative data analysis (QDA) known as Noticing, Collecting, and Thinking about interesting things (Seidel, 1998). 
This project focused only on pointing out the commonalities in the responses of the 11 subjects interviewed using the research question template provided in Appendix A. This project did not include further interviews with a broader range of Christian educational professionals at this time. The project also did not include a second series of interviews to follow up with subjects to further enhance understanding of their initial response to the research questions.

For further development, a broader range of experienced Christian educational professionals could be interviewed to provide a more complete source of insight. In addition, specific questions already asked could be expanded upon to allow the subjects to further expound their views on particular matters such as the use of technology in the $21^{\text {st }}$ century Christian school, the need for increased community, or hiring the right teacher for the $21^{\text {st }}$ century Christian school.

Significance of the Project

The roots of the $20^{\text {th }}$ century Christian education movement in the United States were strong enough to weather the onslaught of a progressive movement that dominated the late $19^{\text {th }}$ and the entire $20^{\text {th }}$ century. We are now eleven years into the $21^{\text {st }}$ century, and some of the life of the Christian education movement in the United States seems to be withering away. With the closing of numerous Christian schools around the nation in this century, one must take account of the state of Christian education and assess its seeming sickly state. Dr. Milt Uecker, Dean of Graduate Studies at Columbia International University stated in an essay entitled The 
Significance of Education, “The decisions made by today’s Christian school leaders are shaping the future character of the Christian school and therefore the continued significance of a Christian school education. These leaders must constantly assess the degree to which a biblical philosophy actually characterizes a school's programs. It will require vigilance to make sure that God's place has not been compromised by the gradual infiltration of lesser gods and worldly ends. In carrying out these tasks, first things will remain first: "But seek first his kingdom and his righteousness, and all these things will be given to you as well” (Matthew 6:33, NIV).

A brief review of the history of the early colonial period in America reveals that many colleges and schools were founded on specifically Christian principles and had strong Christian roots and a foundation similar to that talked about by Dr. Uecker, but over time, the impetus to continue this mission and vision was lost. Consider that Harvard, Yale, Princeton, Dartmouth, and several other primary educational institutions in America were founded with Christian ideals for education but lost their roots within one or a few generations of their founding. This loss of mission and vision for Christian education is a matter of several factors. One factor may include the loss of leaders, including administrators, teachers, and board members, who actually support the mission and vision of a truly biblical framework for learning within the Christian school. Other factors may include an increased focus placed on modern methods of education that are not carefully fitted within the Biblical framework of the original vision. A contradiction then supplants, and eventually overrides the original calling of the Christian school. Whatever the case, the premise of this project is to renew the transformational calling for the ministry of Christian education in the $21^{\text {st }}$ century. Through examination of the responses of the Christian education leaders interviewed and a literary review of what current and former Christian leaders 
wrote, this project is a calling that engages matters perceived to impact the necessary development of the $21^{\text {st }}$ century Christian school.

\section{Methods of Procedure}

An original survey of 14 questions about the needs of Christian schooling in the $21^{\text {st }}$ century has been designed and administered (see Appendix B for complete proof). The study focused on the attitudes and beliefs of administrators from around the country that show the call to renewal within the Christian school movement that will redefine the mission and vision. The survey was delivered in phone conversations with ten different administrators from various regions throughout the country and the written response of one subject. The survey was individually administered and contained only open ended questions to allow participants to answer freely.

The leaders chosen for this study were selected because of their distinguished service to the cause of Christian education, and/or their current involvement in the day to day operations of a Christian school. Several factors were taken into consideration when choosing participants for this study. Regional location was one factor for the choice as well as longevity of commitment to the Christian schooling. Another was the length of time in the Christian school movement. The name and title of each administrator participating is listed below along with a brief biography. 


\section{Bruce Lockerbie}

After 35 years of teaching and administering at The Stony Brook School, D. Bruce Lockerbie now leads a team of consultants called PAIDEIA, Inc. [“pie-day-ah”], working with schools, colleges, universities, and seminaries, as well as churches, helping agencies, and other institutions. His work with college-preparatory students included teaching English and Bible, while serving as chairman of the English and Fine Arts departments, then as Dean of Faculty. Upon retiring from The Stony Brook School, he held the appointment of Thomas F. Staley Foundation Scholar-in-Residence. Lockerbie is author, co-author, or editor of forty books whose topics range broadly including aesthetics, biography, literary and social criticism, history, education, family living, popular theology, as well as textbooks. Recent titles are A Passion for Learning: A History of Christian Thought on Education, From Candy Sales to Committed Donors, Dismissing God: Modern Writers Struggle against Religion, The Timeless Moment: Creativity and the Christian Faith, Thinking-and-Acting Like a Christian, and A Christian Paideia: The Habitual Vision of Greatness. In addition to essays and reviews, Lockerbie contributes to research projects and encyclopedias, such as "Protestant Education" for Encyclopedia of Educational Research and “Christian Education” for the Twentieth Century Encyclopedia of Religious Knowledge, among others. Lockerbie is editor of periodicals called The PAIDEIA Letter and The PAIDEIA Report. A frequent lecturer at schools, colleges, universities, and seminaries, Lockerbie has also held endowed lectureships at the Chautauqua Institution. As a consultant, Lockerbie has worked across the USA and Canada, as well as in Jamaica, Barbados, St. Kitts and Nevis, Dominican Republic, Cayman Islands, Ecuador, Great Britain, France, Switzerland, Germany, Greece, Israel, Kenya, Ethiopia, India, Bangladesh, Thailand, Malaysia, Hong Kong, Taiwan, Japan, Russia, and Uzbekistan. 


\section{Dr. Janet Lowrie Nason}

Dr. Nason is the Asia Director for ACSI, and she works primarily with national schools in Asia, specifically the Filipino Christian School, which currently retains about three hundred and twenty students, the Indonesian Christian School, which currently retains about two hundred and twenty students, and she also operates an office in South Korea but has not started ACSI membership among national schools in that region as of now. Dr. Nason runs programming to develop national leaders for various certification programs. She has the fiduciary responsibility of encouraging financial sustainability for Christian schooling within these regions. She has been the director of three accredited master's programs at the Philadelphia College of the Bible Graduate School leading to an M.S. degree in education, in educational leadership and administration, and in education with an international minor. Dr. Nason is the daughter of the late Dr. Roy W. Lowrie, Jr. who is a founding ACSI Board member and former Headmaster of Delaware County Christian School as well as the author of numerous books on Christian education.

\section{Dr. Barrett Mosbacker}

Dr. Barrett Mosbacker is the Superintendent of Briarwood Christian School in Birmingham, Alabama. BCS enrolls over 1,900 students on two campuses in grades K4-12 with an operating budget of over $\$ 9$ million and nearly 200 employees. As Superintendent, Dr. Mosbacker is responsible for all K4-12 school operations, curriculum and instructional 
development, personnel recruitment, supervision/evaluation and training, long-range and strategic planning, School Board development, school finance, athletics, technology development, admissions, marketing, and facilities. Dr. Mosbacker's doctorate is in educational leadership. He has substantial experience in strategic planning, technology integration, school business management, and leadership development. Prior to his work as a Superintendent, Dr. Mosbacker worked for several U.S. corporations and as a management consultant with the Legal Services Corporation, Washington DC.

\section{Dr. Jane Duffey}

Dr. Duffey has served as the Head of School at Norfolk Christian Schools since 2008 and previously served as the school's Academic Dean and Middle School Principal. She earned a Ph. D. in Educational Leadership from The College of William and Mary, and holds an M.A.Ed. in Special Education from San Diego State University. As Head of School for Norfolk Christian Schools, Duffey oversees all campuses, principals and directors as well as the Office of Curriculum \& Instruction. She works extensively in the areas of long range planning, finance, professional development, community relations and many other roles.

\section{Dr. John Foreman}

Dr. Foreman holds a B.A. in History Education from Cedarville University, an M.A. in Christian School Administration from Grace Theological Seminary, and a Ph.D. in Curriculum Development \& Instructional Leadership from The University of New Mexico / Trinity 
Theological Seminary. For several years, Foreman worked in the Midwest to build his career, and then moved to New Mexico for 15 years serving as both a missionary educator on the Navajo Indian Reservation and later in southern New Mexico at a larger K-12 school. By 2007 he moved back to his home state of Ohio.

As superintendent of Worthington Christian Schools, Foreman oversees all campuses, principals and directors as well as the Office of Curriculum \& Instruction. John works extensively in the areas of long range planning, finance, professional development, community relations, and many other roles.

Worthington Christian is unique among ACSI schools in the Midwest as one of its foundational administrators, Taylor Smith, who is now Vice President of ACSI.

\section{Dr. Randy Ross}

Dr. Randy Ross is in his twelfth year as the Regional Director for the Ohio River Valley Region of ACSI. He has served 44 years in education with experience at the elementary, secondary, undergraduate and graduate levels. He has been a teacher, coach, and counselor, Vice Principal, Principal and Superintendent and has been very active in accreditation, working as a visiting committee member and chairman for the Western Association of Schools and Colleges and ACSI. Dr. Ross has been a regular seminar leader both nationally and internationally. He is currently serving as the Regional Director of the Ohio 
River Valley Region of the Association of Christian Schools International including the states of Ohio, Kentucky, and West Virginia.

\section{Bob Gresh}

GreshBøb holds a B.A. in Public Administration and Political Science from Cedarville University. GreshBob's personal experience with the lack of desire on the part of the school board, administration, or teachers to help move those in need toward restoration led to his passion to develop his "40 Points of Grace” and eventually serve as the founder and Head of School of Grace Prep High School in State College, Pennsylvania. He is also the President of Pure Freedom, a nonprofit ministry focused on purity of heart and life through the Gospel of Jesus Christ. Grace Prep is a Christian school with an interesting philosophy including higher than average pay for its teachers and administrators and an expectation that all teachers and administrators should work together throughout the summer, on salary, in order to prepare for the upcoming school year.

\section{Chris Cleveland}

Cleveland served as high school principal of Providence Christian School in Lilburn, Georgia and as middle school then high school principal of Wesleyan School in Norcross, Georgia before moving into the position of Assistant Headmaster for External Affairs at Wesleyan School. During his time at Wesleyan School, several key administrative initiatives 
have been made including the establishment of an internship program for recent college graduates to explore the reality of Christian school teaching. Cleveland has also led numerous short-term mission trips with high school students around the globe. Cleveland holds a B.A. in History from Auburn University and M.Ed. in Administration and Supervision from The University of Tennessee-Chattanooga. He has served as both a Middle School and High School Principal in various Christian schools.

\section{Dr. Mark Eckel}

Dr. Mark Eckel is Dean of the School of Undergraduate Studies and Professor of Old Testament at Crossroads Bible College in Indianapolis, Indiana. He oversees the traditional education program at the college and also administrates the online and accelerated studies. His focus is on faculty as well as curriculum visionary producing and prompting new programs for the future. He blogs at www.warpanwoof.org on topics concerning biblical worldview. Dr. Eckel is the former Director of the Mahseh Consultation Center and was an Associate Professor of Education at Moody Bible Institute in Chicago, Illinois. He holds a Ph. D. from Southern Baptist Theological Seminary, a Masters in Theology from Grace Theological Seminary, and a B.R.E from Baptist Bible College. Books published by Dr. Eckel include: Rewired: A Worldview Curriculum for Teens. Consultant with Chuck Colson. 2006. The Whole Truth: Classroom Strategies for Biblical Integration. Xulon Press, 2003. Timeless Truth: An Apologetic for the Reliability, Authenticity, and Authority of Scripture. Purposeful Design: 
Colorado Springs, CO, 2001. Let God Be God: A Study of the Nature and Attributes of God. Revised. Purposeful Design: Colorado Springs, CO, 1997, 2003.

\section{Rick Bernhardt}

Bernhardt is the Senior Administrator of Lititz Christian School in Lititz, Pennsylvania. Lititz Christian is a ministry of Grace Church. He oversees an on site child care center as well as pre-kindergarten through grade twelve school. Bernhardt has worked in education for over fifteen years in public schooling as a fourth grade teacher and system wide director of technology advancement for the Warwick School District and in private Christian schooling as a teacher and later Senior Administrator of Lititz Christian School. He earned a B.A. in Elementary Education and a M.Ed. in School Administration from Millersville University of Pennsylvania.

\section{Jeff Woodcock}

Woodcock is the founding Headmaster of Oaks Christian School in Westlake Village, California which also hosts an online virtual school at http://online.oakschristian.org. He holds a B.A. from Cedarville University, an M. Ed. from SUNY Fredonia, and has done doctoral studies at UCLA. Oaks Christian's publicity includes interesting highlights and has centered on children from well-known families enrolled at the school. For instance, ESPN highlighted the 
fact that the sons of Wayne Gretsky, Joe Montana, and Will Smith attend Oaks and play football there. Though the Hollywood hype has drawn public attention and afforded the school some interesting opportunities, Woodcock remains focused on his goals: educational excellence and helping students experience the love of Jesus Christ through the school's teachers and programs. In fact, a number of parents and students have turned to faith in Christ as a result of their experiences at Oaks. Woodcock primarily attributes this to the willingness of the teachers to invest in the lives of their students simply by relating to them and showing them God's love. Oaks Christian School is a college-preparatory Christian school located in Westlake Village, California. The school was founded in 2000 and has over 1,300 on-campus students in grades 612. Oaks Christian Online School provides a rigorous and challenging college- preparatory education for high school students in a Christian environment that builds on the best practices of the main campus. This online Christian learning opportunity is now available globally. 


\section{Chapter Two}

Plenary Literature Review

Overview of Christian Education in the $21^{\text {st }}$ Century: Renewing A Transformational Vision

"I simply believe it’s time for a prophetic and radical reassessment of Christian schooling's operating premises in the twenty-first century. To transform literally means to change an object in composition and structure so that it is no longer recognizable for what it was, only for what it has become” (Lockerbie, 2005, 168).

It is time for Christian schools in the United States to once again pray fervently and work intentionally to fulfill the specific mission and vision to which they are called. Consistent decline in enrollment has forced the closure of numerous schools in the past decade leading to a compelling point in the history of the Christian school movement in the United States. The Association of Christian Schools International (ACSI), which has more than 38,000 member schools worldwide, normally averages 150 school closures each year. It had more than 200 schools close in 2009 (Lopez, 2009).

Christian education helps parents and students to fulfill many requirements within the Biblical mandates for the home and the church. Christian schooling is a unique calling among other forms of Christian education. A Christian school is not a church (De Jong, 1977, 19). Christian schooling is designed to educate students during each day of a given school year within an academic context that fully recognizes Jesus Christ as Lord over all and acknowledges the Bible as the infallible, authoritative, God inspired, objective truth. Likewise, Christian schooling 
has the distinct mission to present all truth as God's truth as stated by Augustine and represented in the $20^{\text {th }}$ century by Dr. Frank E. Gaebelein. Truth presented in the area of mathematics, science, history, English, physical education, athletics, fine arts, student discipline, or Bible class all must be taught within the framework of God's truth for the school to be considered Christian in mission and vision. While many fine Christian schools can state that they have integrated all of the above components into their curriculum for many years, there is a sense that the needs of $21^{\text {st }}$ century Christian school students and families have changed dramatically. Arnold and Hall (2009), state that those still advocating $20^{\text {th }}$ century forms of Christian education with the schooling model look for answers from a model that speaks less and less to today's culture. In order to approach renewing the transformational vision of Christian schooling in the $21^{\text {st }}$ century, several key factors must be addressed.

Christian schooling must be set apart from non-Christian schooling. Student needs must be met and not ignored in any manner that allows the mission of the school to override humanity. Lockerbie shared his vision for Christian school mission in stating, "We need to present an environment that is marked by realism and grace. Realism, recognizing that every one of them (students) is like every one of us (teachers); persons in need of transformation by the atoning work of Jesus Christ” (D.B. Lockerbie, personal interview, March 29, 2011). Technology must be properly integrated into the curriculum. Professionally qualified, spiritually mature, and relationally oriented teachers must be hired and trained. Parents must be sincerely partnered with and taught about the distinctiveness of Christian schooling. The Christian school must seek to transform individual hearts as well as cultural norms through the ministry of current students, teachers, administrators and alumni who represent the mission and vision of the Christian school. 
The transformation of Christian schooling to meet the needs of students and parents in the $21^{\text {st }}$ century is a topic that must be continually researched and developed in the coming years. With the help of recently published articles, the use of books that discuss the distinctiveness of Christian schooling in the $20^{\text {th }}$ century, and personal interviews with current Christian school leaders, it will be possible to clearly articulate a mission and vision for $21^{\text {st }}$ century Christian schooling.

As with any business venture, the good schools of the Christian school movement must make plans to move from existing as merely good Christian schools to transforming themselves into great Christian schools thereby strengthening not only the capital "C" on the Christian in their title, but also innovating the capital "S" on the school in their title. Here in the $21^{\text {st }}$ century, Christian schools must hold onto the traditions of the past and be renewed to set a new course of student centered, relationally vibrant educational methodology for the present and future while carrying on the transformational vision. The direction of this research is to identify common elements of mission and vision calling for renewing this transformation through the voices of eleven Christian school leaders from around the United States interviewed using a series of fourteen pre-drafted questions. Christian school professionals including D. Bruce Lockerbie of Paideia, Inc., Dr. Janet Lowrie Nason of ACSI, Jeff Woodcock of Oaks Christian in Westlake Village, California, Dr. Barret Mosbacker of Briarwood Christian School in Birmingham, Alabama, Dr. John Foreman of Worthington Christian School in Columbus, Ohio, Dr. Randy Ross, Director of the Ohio River Valley Region of ACSI, Rick Bernhardt, Senior Administrator of Lititz Christian School in Lititz, Pennsylvania, Bob Gresh, Founding Headmaster of Grace Prep Academy in State College, Pennsylvania, Dr. Jane Duffey, Head of Schools for Norfolk Christian Schools in Norfolk, Virginia, Chris Cleveland, Assistant Headmaster for External 
Affairs at Wesleyan School in Norcross, Georgia, and Dr. Mark Eckel, Dean of Undergraduate Studies and Professor of Old Testament at Crossroads Bible College in Indianapolis, Indiana, have provided their thoughts to this research to bring about a call to necessary transformation in word, thought, and action for all Christian school professionals to consider. Others such as Albert E. Greene, Donovan Graham, David Dockery, and the late Dr. Frank E. Gaebelein, founding Headmaster of The Stony Brook School in Long Island, New York, is often referred to for their visionary writings that provided fuel for the call to the educational transformation called for in this research.

As stated previously, developing an alternative Christian consciousness among teachers and students in today's secularized society is not the work of one meeting, one memo, or one moment (Greene, 1998, vii). There is a difference between a Christian who teaches and a teacher who teaches Christianly. As Rousas J. Rushdoony stated in The Philosophy of the Christian Curriculum, "Biblical religion is a total faith, and our God a total and sovereign Lord, we must claim every area of life and thought for Christ, and the area of education is a central one, and next to the family, most basic to the life of man” (Rusdoony, 1981, 95). The teacher who teaches Christianly will associate all that is done in academics, fine arts, athletics, spiritual life, and discipline, with the words of God in the Holy Bible. The teacher who thinks Christianly will, by their very life, provide the opportunity for their students to become like them. It must be the mission of every Christian school board member and administrator to continue to hire and retain top notch professionals who think Christianly in all categories to fill the ranks of their particular Christian school. Through the living witness of dedicated teachers who think Christianly, the means of obtaining true Christian schooling will never change, but the methods by which it is delivered must continue to adapt for the age in which the students live. The need 
to adjust methods for teaching students in the $21^{\text {st }}$ century is the crux of this research study. The study that follows will become a scholarly manuscript considering a brief history of Christian schooling, and methods for student centered teaching that has a perceived ability create significant transformation within Christian schools in the $21^{\text {st }}$ century.

Schools have been foundational institutions in America since the very first Puritan settlers landed on the shores of New England. In the colonial period, education was used to maintain the authority of the government and religion. People were taught to read and write so they could obey the laws of God and the State (Spring, 2008, 11). Puritan thinking about the nature of schooling centered on presenting the well-ordered religious society that would win God's approval and be used as a model by the rest of the world (Spring, 2008, 13). Schools in the New England colonies were eventually transformed from instruments of religion to servants of the State (Caldwell, 1996). The history of Christian education in colonial America is the history of the development of general education (Eavey, 1964, 189). Since most early settlers were Protestants, such a large section of them believed that the Gospel of Christ was the only method of salvation that they saw education and faith as essentially united. This was certainly true of the Puritans who were Calvinistic dissenters from the Church of England. However, the Christian element of education in the colonies soon gave way to the onslaught of human reason against the truth of God. The rise of early scientific realism headed up the seventeenth century Enlightenment with its revolt against almost everything including Christianity. After 1650 the advance of science with its emphasis on human reason was rapid. By the middle of the seventeenth century, the spirit of inquiry had extended and is traceable in the presuppositions and habits of thought traceable to Descartes and Kant (Eavey, 1964, 204). This alternative focus 
gave way to the increase of a secular view of the mission and vision of education and led schools of all levels, from the grammar schools which the youngest children attended to the colleges of the colonial period, away from the focus of training up a generation of literate men equipped for the ministry of the church. An early Harvard College brochure, published in 1643, proposed the mission of this particular College's existence: "To advance Learning and perpetuate it to Posterity; dreading to leave an illiterate Ministery to the Churche” (Wright, 2002). This aim for the schools of the New England colonies survived for many years as the prevailing mission and vision for education. While some of the more sexist and socio-economically elitist tendencies of the early colonial schools were happily diminished through the course of the prevailing secularization of schooling, the singularity in purpose of training up a biblically literate collection of students fit to serve the church and the world was diminished with the onset of the modernist view of life and learning. In short, the modernist view of life and learning divided the sacred and the secular into two distinct and utterly unrelated sections of learning. In the early part of the twentieth century, the prominent aspects of Enlightenment thinking could be seen to have triumphed in primary and secondary education. This trend began at the collegiate level first, but the center of focus for this thesis will rest on those things concerned with primary and secondary schooling. Modernist thinking shifted schooling from biblical understanding to success in life, particularly economic success. As Americans thought less and less about the life to come, they thought more and more about earthly success (Greene, 1995, vii). This great focus on earthly success set the trajectory for schools to move away from being Christ centered institutions of learning, where all things were considered through the lens of God's inerrant word, to centers for the promotion and advancement of mankind. The Enlightenment eroded the foundational aims of schools throughout the American colonies and even to this date has a major 
impact on thought and life. Leaders of the Enlightenment era promoted five forms of modern thought separately and collectively to emphasize the human and deemphasize the acknowledgement of God. These five forms of thought include individualism, intellectualism, modernism, scientism, and dualism. This type of thought brought about the ideas of the separation of church and state as well as the secularizing of education by taking it away from the church (Eavey, 1964, 205). As Edgar Alan Poe wrote in The Fall of the House of Usher, "A barely perceptible fissure that widens from a crack into a fault in the foundation”. This crack widened into a fault in the foundation and perpetuated a chasm between the biblical view of education and the modernist view of education. From the middle 1800's to the early part of the $20^{\text {th }}$ century there were signs of the direction that modern thinking was taking education in America. As further anti-Christian moves were made to separate all teaching of God or the Bible from general schools, the entire foundation of schooling in the United States became secular. As Dr. A.A. Hodge of Princeton Theological Seminary noted in a lecture in 1887 that a comprehensive and centralized system of national education, separated from religion, will prove the most appalling enginery for the propagation of anti-Christian and atheistic unbelief, and of anti-social nihilistic ethics, individual, social and political, which this sin-rent world has ever seen (Hodge, 1887, p. 283).

To stem the rising tide of anti-biblical educational systems, Mennonite congregations began a movement of schools that spread across the nation from as early as 1701 until 1959 where 160 Christian day schools were reported. Along with this many other Protestant denominations began to develop Christian day schools in the early $20^{\text {th }}$ century. Lutheran and Catholic schools also began to appear at the same time. It was not until after WWI that a new 
breed of Christian schools were envisioned to bring about the type of mission and vision that would encourage students to think biblically in all categories of education. This visionary movement in Christian schooling seems to have coincided with the rise of the Fundamentalist movement. A visionary example of this new mission for Christian schooling was begun in the fall of 1922 in Long Island, New York. The Stony Brook Association had buildings housing summer Bible conferences that they believed could be used well throughout the year to begin a Christian school. At merely 23 years of age, a bright and eager educator was hired to help this new Christian school experiment begin at The Stony Brook School in the fall of 1922. Mr. Frank E. Gaebelein began his work at Stony Brook with nine men and women appointed to teach a total of 27 boys (Lockerbie, 2005). Throughout the remainder of the twentieth century, Christian schools were conceived all around the country as scores of visionary Christian leaders headed the call to raise up a new generation of students with a specifically biblical worldview. Stories of the faithfulness of God's people to answer his call to create schools to educate and empower a new generation of students are numerous. Carper and Laymen reported in 1995 that from the 1950s to the mid-1960s, when Lutheran, Calvinist, Episcopal, and Seventh-day Adventist schools dominated this segment of private education, fundamentalist and evangelical Protestants and their churches, few of which are members of "mainline" denominations, established alternatives to public education that are often referred to as independent Christian day schools. As many as 150 Christian day schools were founded between the 1920 s and the 1960s. Some noteworthy Christian schools founded in this time frame that still exist as strong Christian schools today include The Stony Brook School, Long Island, New York, Delaware County Christian School, New Town Square, Pennsylvania, Norfolk Christian Schools, Norfolk, Virginia, and Dayton Christian Schools, in Dayton, Ohio. It was not until the 1960s, however, 
that disenchantment with the ongoing secularization of state schools, a resurgent evangelical faith, and, in some cases, fears related to desegregation sparked the rapid increase in the number of Christian day schools. All of these schools profess centrality of Jesus Christ and the Bible in their educational endeavors and attempt to inculcate a Christian worldview, but are quite diverse in facilities, size, and ethos. The National Center for Education Statistics reports that approximately 10,000 Christian day schools were founded between the 1960s and 1990s, most of which were racially integrated by the end of the century. Furthermore, in the 1980s and 1990s a small but growing number of these schools were established by and for African Americans. By 2000 enrollment in Christian day schools, most of which are affiliated with either ACSI or the more conservative American Association of Christian Schools (AACS), exceeded 1 million.

As with many movements, there are positive and negative aspects of the history of the Christian school movement. The positive aspect of this movement was the visionary call to separate from the modernist vision of a society that would eventually ban the reading of the Bible and prayer in all public schools. One negative aspect of this movement was the historical coincidence the Christian school explosion from the 1950s to the 1960s had with the desegregation of public schools. Whether the intentions were thus associated with desegregation or not, the demographic facts for many Christian schools seem to be that they took on a mostly white student and parent body and were socio-economically upper class to upper middle class citizens in terms of wealth. In the haste to move from the public schools to a model of Christian schooling, many Christian schools may not have truly considered the unique mission and vision they were being called to, but rather took on the form of the public school with a veneer of Christian thought and practice. Despite the flaws, Christian schooling survived and even thrived 
in the later part of the $20^{\text {th }}$ century, but today the movement has lost momentum in the United States. Dr. Janet Lowrie Nason, ASCI Asia Director stated in her interview for this project that "December (2010) was a tipping point in terms of membership of individual students that for the first time the number of international students in ACSI schools is now larger for those outside North America than inside.” This is a wonderful factor for Christian schools outside the United States, but inside the country, a radical reassessment is needed in Christian schooling to determine the purposes for this decline in student attendance.

The particular nature of this research does not provide adequate space to outline the whole history of Christian schooling in the United States. The central focus of this research is the call to invest in the intentional transformation of the $21^{\text {st }}$ century Christian school. What Christian education needs is a biblical framework for transformational education in the $21^{\text {st }}$ century. Curriculums such as ABEKA and ACE have not provided the type of Christian schooling that will sustain long term academic and spiritual growth. To this end, eleven highly qualified Christian school leaders from various regions of the United States have been interviewed. These subjects represent various levels of leadership from principals, to heads of school, to CEO's of consulting firms. Each Christian school leader interviewed was asked to answer a series of questions about Christian schooling for the $21^{\text {st }}$ century. 


\section{Chapter Three}

Methodology

Collection of Interviews and Coding

Interviews were conducted vis-à-vis digitally recording in person and/or phone interviews with each of the eleven participants. Once these interviews were complete, they were transcribed, and a qualitative data analysis method of noticing, collecting, and thinking about things (Seidel, 1998) was conducted until a significant amount of saturation occurred. It is doubtful that full saturation has occurred in the span of research for this particular thesis as the data in the transcriptions is extremely rich when compared to the scope of a thesis project of this size (Appendix B). Of those threads that were noticed in the qualitative data analysis that was conducted for this research, a list of coded terms can be provided. These coded theories are a result of the interpretation of the data gathered from the interviews.

According to a comparison of the responses given by participants interviewed, Christian schools need to move forward in the $21^{\text {st }}$ century, as Dr. Randy Ross stated, with the "foot of faith and the foot of responsibility in the vein of Psalm 37:3 which states "Trust in the Lord with the foot of faith and do good with the foot of responsibility”. Christian school workers need to develop a concise mission and vision for their particular calling to Christian schooling. Using the data from the interviews collected in the appendix B of this thesis, there is ample opportunity for further study and reflection on the direction of Christian schooling in the $21^{\text {st }}$ century. 
Of the participants interviewed, all eleven answered the first question regarding what they believe to be the key elements that set Christian schooling apart from secular public schooling by stating in some form that a specifically Christian mission and faculty is of the highest significance. D. Bruce Lockerbie reminisced about the words of his mentor Frank E. Gaebelein when he stated that the sine qua non of Christian schooling is no Christian school without Christian teachers. Jeff Woodcock of Oaks Christian School stated, “I think it's important that we have a unified faith in Christ, and that certainly sets you apart from public schools. It's the one unifying factor that brings the staff together for a common vision and that's a spiritual vision in addition to the other vision that schools support”. Dr. Janet Lowrie Nason commented that the key element that sets Christian schools apart is the unique philosophy that faith in Jesus Christ impacts the whole school. Dr. Barret Mosbacker and Dr. John Foreman stated that the commitment to a Christian world view was paramount. Dr. Jane Duffey stated that Christian schools cannot lose sight of their mission to reflect God on earth. Other participants interviewed mentioned the need for Christian maturity and the significance of the calling that must be present for mature adults to be placed in the service of Christian school teaching. It is apparent that the faith represented by the teacher is paramount to the success of the mission of the Christian school to fulfill its particular mission and vision in the $21^{\text {st }}$ century. Along with this calling to the centrality of Christian teachers fulfilling the mission and vision of the school, there are stories of distant and also more recent history that display the certain loss of Christian mission and vision in schools when non-Christian faculty or administration are brought in to the Christian school community. One recent example of the apostasy of the Christian school was noted in the research interviews as shared knowledge and experience between D. Bruce Lockerbie and the writer of this article. It is therefore, the necessary duty of all leaders involved 
with the Christian school to protect and uphold that most prominent evidence for the continuation of the mission and vision of the school, the integrity of the faith of its Christian faculty members.

Of course, the calling to bring about the integrity of committed, Christian faith among the faculty must be sincerely cared for by the administration and governing board of the Christian school. The faith of these teachers seems to be continually grown and nurtured by the ongoing process of discipleship and prayer for and with the Christian teacher as emphasized by Roy Lowrie in a volume of collected personal journal writings entitled, Inside the Christian School, when he commented that, "It is certain that the work of the flesh will never solve the problem. What is needed is what James wrote when he said, The effectual, fervent prayer of a righteous man availeth much” (Lowrie, 1980, 46). If this aspect of discipleship and prayer is left out of the equation of leadership, the Christian school may soon fail to have truly Christian teachers. If nothing else, it will certainly have rejected its responsibility to develop Christian teachers who integrate the Bible naturally and willingly into every lesson they teach. As we learn in Proverbs 29:18, "Where there is no vision, the people perish".

With nearly all interviewed identifying this as a key element, the vision to provide students the ability to construct meaning rather than present only facts in a lecture format was highly common. Sources from the National Training Laboratories in Bethel, Maine developed a learning pyramid that bears out this academic reality by showing that students learn nearly 90 percent more by teaching others and participating in other student-centered learning activities than they do by listening to a lecture. Rather than simply restating learned facts, students must be called to think Christianly in all categories. Becoming critical thinkers, of course, implies 
assessing the views of others and one's own views according to acceptable standards of appraisal (Norris, 1985). According to interview participants such as Dr. Barrett Mosbacker of Briarwood Christian, one distinctive of $21^{\text {st }}$ century Christian school students is the ability to have information at their fingertips via the internet.

The need for healthy relationships between students, teachers and administrators at all levels of Christian schooling was heavily mentioned by all interviewed for this research. Often mentioned was also the matter of the broken family structures of the $21^{\text {st }}$ century home and the desire for transparency in relationships. Of course, closely attached to this call for relationship is the need for the teacher of the $21^{\text {st }}$ century to be well matured and prepared for the tricky balance between relating well to students and maintaining a position of God ordained authority. It should be noted that this need for strong student relationship is so high among those interviewed that nearly all mentioned its necessity for the modern Christian school teacher at some point in their interview. In working toward this goal of meeting student needs through relationship, Bob Gresh, founder and CEO of Grace Prep Academy in State College, Pennsylvania mentioned one method that his school has developed. Gresh believes the time outside of class is so important that on Thursdays, Grace Prep bases its entire schedule on discipleship groups. They call them "D Groups". Every teacher at the school has five students in their "D Group”. They have to be able to fit in their car, if they have a mini-van, they can have six students. They have a chapel on Thursday and an hour long lunch when they take those students out very week. The students pay for their own lunch, but the faculty members take them out, and they just talk about chapel as well as other items of conversation that may come about. Grace Prep’s discipleship model even extends to the point where if a parent or student has a real problem, the "D Group" leader is responsible to work with the family first because the teacher knows that student better than 
anyone else in the school and the student has a personal connection to that teacher. This revolutionary model is something that could seriously fill the relational void between teachers and students in so many Christian schools and could build mentoring capital into the lives of students from broken or dysfunctional homes.

As teachers and administrators relate to students in the $21^{\text {st }}$ century, there must be a stronger leaning into elements of grace and realism in the interactions, rule books, and handling of discipline in the Christian school. Lockerbie noted in his interview one of the things that is rarely spoken of in Christian schooling, the need to create an institutional environment. This means person after person after person sharing the same intentions and same goals. We need to present an environment that is marked by realism and grace. Realism is recognizing that every one of the students is like every one of us, persons in need of transformation by the atoning work of Jesus Christ. We are all the same in nature. Second, we need to exercise grace in recognizing that we are working with the unformed, unshaped, immature, pre-adolescent and young adult and they're going to make mistakes; they're going to blunder; they're going to fail; they're going to disappoint just as, if the truth were told, some of us will also. It often seems that the Christian school is the first to walk away from the familiar passages of the scriptures when there is a rule violated in the handbooks and grace might be implemented to cover over this sin. Rather than providing a measure of mercy for the student and family mixed with a term of accountability, the Christian school tends to provide straight discipline with an eye toward expedience of ousting the undesirable actions rather than transforming attitudes. This may be in part because an already overtaxed administration at many small, Christian schools does not have the time to spend in follow up with a struggling student, or it could be due to the notion that we are not willing to 
practice the mercy that we teach in Ephesians 2:8. "For it is by grace you have been saved through faith. It is the gift of God so that no man may boast”.

Gresh goes on to expand his case for the importance of creating excellent discipleship environments for students in the $21^{\text {st }}$ century Christian school by talking about a scenario which research shows is increasingly common today. The United States has the highest rate of teen pregnancy in the fully industrialized world. While the rates have been declining in the last 15 years, it remains a source of concern that $34 \%$ of teenage girls in the U.S. are becoming pregnant at least once before the age of 20. The teen pregnancy in the U.S. rate is ten times that of Japan, four times those of France and Germany, and nearly twice that of Great Britain (Justice \& Democracy forum on Leading Social Indicators. William S. Boyd School of Law). "I mean, a male student's having sex with his girlfriend, but he can't tell you because you'll kick him out of school. What does that say about our relationships? Now, that makes you think differently. You know, do you just let the kid go on sinning? No, because if he's repented then it's something different, but what are you saying if you don't respond to this boy in love and instead kick him out of the school? I mean, if you sin you're going to be cast out of the community”. This sort of casting out of the community is just the thing that many Christian school students fear if they ever bring any sort of trouble they are experiencing or have caused into the administrative offices at the school. Relationships must be built on mutually beneficial trust in the Christian school of the $21^{\text {st }}$ century. They cannot be built on the notion that "anything goes", but we must demonstrate that relationships, discipleship, and forgiveness and grace in Christ are real and not only talked about pieces of the Gospel. This sort of transformational vision seems to coincide well with the instruction in Hebrews (11:6), "Anyone who comes to God must believe that He 
exists, and that he rewards those who earnestly seek Him.” Unfortunately, we often portray a less transformational message in Christian schools that would scare away even the most pious students from telling us about their troubles and allowing us to pray for them in their time of need.

Of all the interviews, there are two that rise to the top in their passion for grace and realism in modern Christian schooling. The most poignant thoughts were from the veteran voice of D. Bruce Lockerbie, and the more contemporary voice of Bob Gresh. Gresh started his school as a radically gracious approach to Christian education in the $21^{\text {st }}$ century. A close reading of the appendix of this thesis, specifically the interview with Gresh, will provide you with an example of the lack of grace inherent in some Christian schools and even Christian churches. Even though their Christian school backgrounds are somewhat different, with Grace Prep being mostly middle class to lower middle class students and Stony Brook being mostly upper class students, both men stated, in their own terms, that the modern Christian school needed to give greater emphasis to the grace of Christ and less emphasis to pietistic language. It is possible that the faith by which some Christian schools have believed has become greater than the faith which all Christian schools must believe. The common faith in Jesus Christ as revealed in the Bible is the faith which sets prisoners free from captivity by helping them to understand that they are sinners in need of salvation and allowing them to make a conscious choice to relinquish that sin based on the opportunity afforded them by grace. Of course, the grace of God in Christ and the grace of their teacher or administrator to provide discipline is a beginning of renewed discipleship.

The need for creative teaching that involves community based learning and collaboration was mentioned regularly by all subjects interviewed. The community based ideals mentioned 
included various suggestions and methods that could be applied to Christian schools in general. Headmaster of Oaks Christian, Jeff Woodcock, mentioned the online learning community that Oaks Christian is developing to serve a wider set of Christian school students and parents with their unique version of Christian school curriculum in a virtualized environment. Likewise, Dr. Barrett Mosbacker from Briarwood Christian Academy in Birmingham, Alabama noted that the whole nature of being able to collaborate online and in other forms, not only with one's peers within a classroom or a campus itself but across international borders, is of great value. Briarwood has Chinese-Mandarin programs; their students have video conferences with Chinese students in China. One of their Bible classes is connecting with a class in Beirut, Lebanon. Learning to use modern tools such as the internet, not just to communicate but to actually engage in collaborative projects, is essential. Most major corporations in the world have work forces that are widely dispersed across international borders and thus use extensive online collaboration, so Dr. Mosbacker points that out as an essential skill. With the rise of collaborative forms of technology such as smart phones and texting and social media networks such as Face book, movement toward a more collaborative learning environment is not just an option for Christian schools today, it is an obligation. It is not supposed by many subjects interviewed that Christian schools must have the latest technology to establish appropriate collaborative learning environments, but they all agree that students must be allowed to construct meaning in group settings rather than to simply reiterate facts that were previously lectured upon or given to them in handouts or textbooks. Those desiring to teach students biblical discernment of social media sources such as Face book need to emphasize biblical virtues of character. Mr. Rick Bernhardt, the Senior Administrator of Lititz Christian School in Lititz, Pennsylvania commented that he believes the number of Face book friendships that exist among Christian school students today 
belies the reality that students are looking for genuine relationships and authenticity. They are not finding that authenticity, so they continue to look for authenticity by "friending” more and more people on Face book. Bernhardt goes on to state that the opportunity for Christian school students to become grounded in Christian thinking is essential, but they often do not understand their need for this grounding. The direction of this research would suggest that serious consideration be given to providing a biblical rationale for students to better understand and utilize their social media outlets.

While Christian schools must work to help students correlate biblical education with the use of their personal media outlets, it is also suggested that Christian schools modernize their curriculum to allow for applications that students will more than likely encounter in the $21^{\text {st }}$ century. Applications include course work done completely online or in a virtualized online setting. Dr. Janet Lowrie Nason stated that distance learning is a major issue today. She believes that every high school student should have to take a distance education course in order to learn how to communicate with a teacher and fellow students in this format. Teaching students in Christian schools how to operate in this manner as soon as possible is helpful and practical in such a technology driven society.

Another element of similar response by the various administrators interviewed was that mission and vision impacts all that is done within the modern Christian school. It was the work of Peter Drucker, instilling a sense of mission in American industry in the 1940s and 1950s, that brought mission to the forefront of school thought. The beginnings of this emphasis were mentioned in Lockerbie’s interview. Lockerbie stated that for the modern Christian school, "mission is our temporal academic purpose. Vision is our eternal spiritual purpose" (D.B. 
Lockerbie, personal interview, March 29, 2011). Our daily operation of the mission of Christian schooling must be of integrity and consistency and should lead to the hoped for vision of our graduates going on to serve God and their fellow man in a manner of fulfilling the first and second great commandments noted by Christ in the gospels. Both the mission and the vision must be defined by each particular school, and vision is something that must be planned and tangibly played out through the work that a school produces, "a coherent and well thought through mission statement”, as stated by Jeff Woodcock of Oaks Christian. In his interview Woodcock noted that Oaks Christian is very mission driven. Everything they have created revolves around the mission statement. The Oaks Christian mission is, "To dedicate ourselves to Christ in the pursuit of academic excellence, artistic expression, and athletic distinction, while growing in knowledge and wisdom through God's abundant grace." They have three pillars revolving around being dedicated to Christ in three piers: academic excellence, artistic expression, and athletic distinction. And so, all these things become important elements of who they are. They also have a very specific vision statement at Oaks which reads, "Minds for leadership, hearts for service" (Oaks Christian Handbook, 2011).

In addition to the mission and vision of Christian education, there is an obvious distinctive similarity in response to the question as to what sets Christian schooling apart from secular schooling in the $21^{\text {st }}$ century. That similarity comes through the distinct Christian philosophy and world view of Christian education. This philosophy was mentioned by several of the educators interviewed. Nason says it very comprehensively when she states, "we have a faith in Jesus Christ, and that impacts the total Christian school, so that impacts what we believe about eternity, what we believe about the nature of children, the values that we have in hiring and 
identifying teachers that will carry out that philosophy in the classroom and impacts discipline, administration, board, everything. Therefore, the very nature of all that we do, or attempt to do, within the body of Christian education should fall under this point of view" (J. Lowrie Nason, personal interview, March 31, 2011). Even more emphatically, Mark Eckel of Crossroads Bible College in Indianapolis, Indiana states, “I honestly don't think that we are and I don't think that we ever will be distinctive from pagan schooling until, and unless, we are actually going back to a true faith-learning paradigm where we think the foundation of all subjects from a Christian point of view, a biblical point of view and we see the permeation of that from every single thing that we do" (M. Eckel, personal interview, April 6, 2011). The “everything” within Eckel’s statement is a radical departure from the sort of lukewarm approach that many Christian schools take to educating their children in the truth. When a $21^{\text {st }}$ century Christian school does not see, as Gaebelein stated, "the unity of all truth under God", then the various parts of learning in the areas of academics, the arts, athletics, and even spiritual life, are left to the interpretation of each person who may come along to take up the teaching of these individual parts. It is essential that the world view of each student be developed fully in wholeness and integrity so that worldly education might not be the task to overcome in the minds and lives of the students we are called to teach. A worldview founded upon an integration of Christian faith and life is the goal of real Christian schooling.

In order to tackle the monumental task of renewing the transformational vision of Christian education in the 21st century, there is a long corrective process that must be put in place and worked without stop in individual Christian schools as well as amongst accrediting Christian school bodies such as ACSI, Christian Schools International (CSI), and AACS. As 
Albert E. Greene notes in his book Reclaiming The Future of Christian Education: A

Transforming Vision, "Correcting this situation will be a long process. It will require patience and persistence in generous quantities. We must not be discouraged at the formidable size of the task, nor must we attempt to short-circuit the working of the Holy Spirit by pressing too hard for immediate results". One of the defining similarities in response among all of those interviewed within this research is the necessity of relationship in reaching today's Christian students. Randy Ross, ACSI Regional Director for the Ohio River Valley stated, “a primary need in today's culture is for relationships, meaningful relationships, relationships with confident, mutual trust. If you go to Scripture, you know, whether it's Old Testament or New Testament, the two primary commandments are: Love the Lord your God, and love your neighbor as yourself. (These) are about relationships” (R. Ross, personal interview, April 11, 2011). So, we see that relationships play a major role in the needs of the $21^{\text {st }}$ century Christian school student. An even more complete view of this matter was presented in an interview with Bernhardt who stated, "Students have learned to not respect authority because of a position that they are in. They want real relationships, and we see that through social networking. The reason that they are having these shallow relationships that we're talking about right now is not because they want 250 friends with shallow relationships; I believe they're looking for a deeper relationship, and so they just keep going from person to person. So, they want genuine relationships, authenticity” (R. Bernhardt, personal interview, April 8, 2011). As teachers and administrators in Christian schools realize this need, something must be done to respond and create ways for students and teachers to truly engage in relationships that set a tone for transparency and grace rather than positional trust, which is currently not being granted readily by students in the $21^{\text {st }}$ century. Dr. Jane Duffey, from Norfolk Christian shared that some of the younger teachers at Norfolk 
Christian are coming in and blogging in their classes as a way to engage modern students relationally through the use of technology. Since $21^{\text {st }}$ century Christian school students are used to blogging or reading blogs, they may greatly respond to this update in relationship and response to the teacher through the mode of internet use.

In the area of instruction, the second question regarding differences that these educators saw between students of past generations and the current $21^{\text {st }}$ century student included a fair variety of responses, but three major issues rose to the top of the conversations when compared side by side. The common issues stated included the need for teachers to provide critical thinking skills to students rather than merely stating facts for memorization and recitation. Research by philosophers of education provides research based support for the similar notions of my interviewees (McPeck, 1981; Siegel, 1980, 1984). Mosbacker noted in his interview that, "students have literally in their pocket access to a universal world of information. I carry an iPad, reloaded, I have a whole Stone Age worth of books there, I have whole library full of other books, I have research articles, I can access the internet, et cetera, et cetera and that is true of our students as well. They are able to access basic information within minutes. So, I think that one of the distinctive is the ability to have information which means that the classroom needs to focus a bit less on providing information and a whole lot more on how to access, analyze, assess that information and a whole lot more on the issue of critical thinking. You don't have to spend much time accessing information; you spend more time working with that information.” The need to think critically is often mentioned as a low point of modern education, but it is actually well researched and proven through critical thinking tests such as the Cornell Critical Thinking Tests, Levels X and Z (Ennis and Millman, 1985). Additionally, leaders such as Lowrie Nason, ACSI Asia Director noted from her work with Christian schooling around the globe, that 21st century 
students are connected to information, "in a way that we have never thought of, and they're connected and are able to get information at their fingertips. So, traditional models of learning the capitals of states is kind of ridiculous because your telephone can tell you what the capital of the state is and so, if their phones are connected to the internet, they have access to instant information and facts. Memorizing and knowing all those facts are not really important (in the $21^{\text {st }}$ century).” In conjunction with this call to promote critical thinking among Christian school students, there is also an insight among those leaders interviewed that points directly toward the increasing need for a collaborative learning environment.

Duffey clearly identified some of the changing tide of Christian schooling in the 21st century when she stated, "We are part of a community and so we have to understand what community life means, and of course, that has changed so much in this 21st century because they (our students) speak at the global village. As Christians we talk about being ambassadors to the world. They (our students) truly are getting that idea of being ambassadors to the world. They are probably getting the true sense of the meaning better than students did fifty years ago or twenty years ago even. So, I think that education in the 21st century, the Christian education of the 21st century has evolved greatly from what Christian education started out as in the emerging years in the 60's. I think the scope of it has really enlarged quite a bit.” This global scope of the community responsibilities that our students have upon the shoulders of their generation is certainly something that is a Brave New World of sorts, desiring "Community, Identity, Stability” (Huxley, 1932). The need for these three important desires for human life to be fulfilled seems to be growing in intensity according to those interviewed, and the need for the Christian school to fill in where society is generally leaving off is evident. Consider this statement made by Chris Cleveland, Assistant Headmaster for External Affairs at Wesleyan 
School in Norcross, Georgia. "This generation needs safety, security, stability, and peace. I actually think that all of the chaos of this world gives us, as Christian educators, a fantastic opportunity. What a great contrast we have to offer compared to the world. In the face of instability, chaos, constant change and a breakneck pace, we can demonstrate to students the peace, calm, safety, stability, and consistency of Jesus Christ. God never changes. Nothing ever surprises him. His peace is the peace that transcends all understanding. As the world gets worse, God looks better and better, and that is a story we need to tell our students.” Confirming this statement by Cleveland were others who mentioned the broken homes that were becoming even more prevalent among families in Christian schools.

When asked to identify two to three necessary changes that teachers must make to reach students in the $21^{\text {st }}$ century, there were four similar responses given among the subjects interview. These four basic responses were coded as passion and creativity in the classroom, interpersonal relationships, and technology integration. 


\section{Chapter Four}

\section{Discussion and Implications}

\section{Strengths of the Project}

The most important strength of this project is the raw research gained through interviews, and referenced sources in the paper provide a framework for better further research. Providing a solid understanding of some of the historical background of Christian education as well as providing a set of data through one on one interviews that directs attention to the needs of the $21^{\text {st }}$ century Christian school is important as well. The success of the project can be judged in a two-fold manner at present. The first indicator of success came in the form of the personal learning of the researcher in the area of history, philosophy, and practice within the field of Christian education. Even within the Christian college or university, the specifics of Christian education are covered lightly or not at all so as to set the Christian educator up with a wholly secular view of education that is integrated with faith sparingly. The second indicator of success came through the ready ability of the researcher to share concepts from the reading of books and articles highlighted in the literature review with other faculty members.

\section{Limitations}

Transforming Christian education in the $21^{\text {st }}$ century is a vast project. The interviews that were taken and listed in the appendix as well as the literature that was reviewed are much more 
than could be elucidated in this particular research manuscript. The body of interviews should be used to extract more common threads of research for the development of other branches of research in Christian education. While this research manuscript presents a call to transform Christian education in the $21^{\text {st }}$ century, there is a matter of perceived disagreement in the Christian school movement that the researcher has not been considerate of until a recent interview with Jack Layman from Columbia International University. This disagreement has to do with the very foundational approaches to Christian schooling including the nature of truth, the integration of the Bible into the school life, and the nature of the Christian school curriculum.

Another limitation lies in the lack of research on the foundations of the Christian school movement in recent years regarding the school's effectiveness and mission. In order to help the researcher better understand certain philosophical aspects of the foundations of Christian education, Layman shared his class notes which could be used in future studies conducted based upon this research.

\section{Suggestions for Further Study}

The leaders interviewed were not asked for a recitation of the common points of Christianity that must be adhered to for faculty membership in their Christian school, so we will have to assume basic theological tenants in this particular instance. Perhaps this topic may be developed in future research studies. Additionally, Christian educational history could be written in an updated format to include many of the $20^{\text {th }}$ century icons of Christian education that were 
mentioned in this paper including the views of Frank E. Gaebelein, Roy Lowrie Jr., Gene Garrick, and several others.

Further study may be done to review the distinctive nature of virtualized and online Christian school learning through schools such as Oaks Christian. Likewise more study could be done through the addition of Layman's personal notes for Christian educational foundations and philosophy from Columbia International University. 


\section{REFERENCES}

Caelli, K., Ray, L., \& Mill, J. (2003). “Clear as mud”: Toward greater clarity in generic qualitative research. International Journal of Qualitative Methods, 2(2). Article 1.

Carper, James C., and Layman, Jack. 1997. "Black Flight Academies: The New Christian Day Schools." Educational Forum 61 (2):114-121.

Carper, James C., and Layman, Jack. 1995. "Independent Christian Day Schools: Past, Present, and Prognosis." Journal of Research on Christian Education 4 (1):7-19.

De Jong, Norman. (1977). Philosophy of Education: A Christian Approach, Nutley, New Jersey. Presbyterian and Reformed Publishing Co. 19

Dockery, David S. (2008). Renewing Minds: Serving Church and Society through Christian Higher Education. Nashville, Tennessee. B\&H Academic.

Eavey, C. B. (1964). History of Christian Education, Chicago: IL. Moody Press. 189

Gaebelein, Frank E. (1995). Christian Education In A Democracy Colorado Springs: CO. Association of Christian Schools International.

Gaebelein, Frank E. (1968). The Pattern of God's Truth: The Integration of Faith and Learning, Oxford University Press, Inc.

Graham, Donovan L. (2003). Teaching Redemptively: Bringing Grace and Truth Into Your Classroom, Colorado Springs: CO. Purposeful Design Publications, A Division of ACSI.

Greene, Albert E. (1998). Reclaiming the Future of Christian Education: A Transforming Vision. Colorado Springs: CA. Association of Christian Schools International. vii

Humanist Manifesto I (1933)

Henry, Carl F. H. (1984). The Christian Mindset In A Secular Society: Promoting Evangelical Renewal \& National Righteousness, Portland, Oregon. Multnomah Press. 84

Huxley, Aldous (1932). Brave New World. Chatto and Windus, London.

Johnson, B \& Christensen, L. (2008). Educational research: Quantitative, qualitative, and mixed approaches. Thousand Oaks, CA: Sage Publications. 410-419. 
Knight, George R. (1998). Issues \& Alternatives In Educational Philosophy, Berrien Springs, Michigan. Andrews University Press. 82-83

Lockerbie, D. Bruce. (2005). A Christian Paideia: The Habitual Vision of Greatness Colorado Springs: CO. Purposeful Design Publications, A Division of ACSI. 168, 212

Lowrie, Roy W. Jr. (1984). Administration of the Christian School, Whittier, CA. The Association of Christian Schools International. 11-13

Lowrie, Roy W. Jr. (1980). Inside The Christian School: From the Headmaster's Diary, Whittier, CA. The Association of Christian School International. 46.

Lowrie, Roy W. Jr., (1982). To Christian School Parents, Whittier, CA. The Association of Christian Schools International.

Norris, Steven P. (2003). EBSCO Publishing

Rushdoony, Rousas J. (1981). The Philosophy of the Christian Curriculum, Vallecito, California. Ross House Books.

Seidel, John V. (1998). “Qualitative Data Analysis”. The Ethnograph v. 5

Shalin, Dimitri. (2004). Teen Sexuality and Pregnancy in Nevada. Justice \& Democracy forum On the Leading Social Indicators. 1.

Spring, Joel. (2005). The American School: From the Puritans to No Child Left Behind Boston: MA. McGraw-Hill Higher Education. 11-13

The Holy Bible. NIV, Zondervan, Grand Rapids, Michigan, 1984

Uecker, Miton V. (2010). The Significance of Education, ACSI

Van Til, Cornelius. (1974). Essays on Christian Education, Presbyterian and Reformed Publishing Co. 27-28

http://web.engr.oregonstate.edu/ funkk/Personal/worldview.html 


\section{APPENDIX}

Appendix A: Self-Created Project Script \& Questions

Appendix B: Transcripts of Interviews with selected Christian educators 


\section{APPENDIX A}

\section{“Christian Education for the $21^{\text {st }}$ Century” Project: Script \& Questions}

I am interested in gaining your thoughts on the development of improved learning environments for the $21^{\text {st }}$ century Christian school, and how you have developed or hope to develop your goals in Christian schooling. I'm also interested in hearing about the core values and beliefs that embody your work as a Christian educator, administrator, and/or researcher/consultant.

The focus of my project is to develop a coherent set of qualitative insights that point to trends in Christian schools that have sensitivity to the methods and mediums that are making, or have perceived ability to make, the greatest influence on students in $21^{\text {st }}$ century Christian schools. I would like to identify trends that signal a movement toward transformational Christian schooling for the $21^{\text {st }}$ century.

Interview Questions

1. What are the key elements that you believe should set Christian schooling apart from secular schooling in the $21^{\text {st }}$ century?

2. What specific needs of students in this generation stand out to you as unique or different from past generations?

3. Identify two to three necessary changes that teachers must make to reach students in the $21^{\text {st }}$ century?

4. What technological needs do you see as essential to be taught and used in the $21^{\text {st }}$ century Christian school?

5. What key issues do you think most divide students and their teachers in the $21^{\text {st }}$ century?

6. Have you made any suggestions to teachers as to how they might change their teaching to reach today's students?

7. What specific steps do you feel must be taken quickly to bring about the sort of learning environment you see as most beneficial for $21^{\text {st }}$ century students?

8. If you are involved in a hiring process, what qualities or characteristics would you look for in applicants that would provide students the kind of education we've been talking about?

9. Please tell me about a time that you felt most positive about your work and that your goals values in Christian education were being met.

10. Without worrying about being modest, please tell me what it was about you - your qualities, capacities, decisions you made or actions your took - that contributed to the situation.

11. What specific situations or events have shaped the way you view education, the way you relate with students, parents, colleagues and others?

12. How can your methods for adapting to the needs of $21^{\text {st }}$ century be brought to the minds and methodologies of our current Christian school teachers?

13. What role do you see parents playing the $21^{\text {st }}$ century Christian school?

14. Are there any thoughts on the need to transform education in the $21^{\text {st }}$ century Christian school that I have not asked but you would like to share with me now? 


\section{APPENDIX B}

Title: Face to Face interview with Rick Bernhardt

Date/Time Recorded: 4/8/2011 10:57:58 AM

Record time: 1:09:35

GP: Okay, so I'm here today with Mr. Rick Bernhardt, and he is with Lititz Christian School. Rick, can you tell me a little bit about your position here with Lititz Christian, your title, and maybe some of your job responsibility?

RB: Um, I am the Senior Administrator of Lititz Christian School which is a ministry of Grace Church. The purpose of me being here from the church's perspective would be to bring unity to the entire ministry, between the ministries because there are three significant ministries which would be the church, a childcare center, and the school, bringing oversight to the school and the center and having them work together with the church so that all of, all three entities would be more successful in achieving our ultimate goal which is building the Kingdom for God.

GP: Very good, thank you. Well, we talked a little bit before I turned the recorder on of what my thesis was about so you got a little background here, I'm gonna launch into the questions and just feel free to give a response in any way your mind and heart lead. Question number one: What are the key elements that you believe should set Christian schooling apart from secular schooling here in the 21st century?

RB: The number one thing that sticks out in my mind would be the faculty. [Voices in the background] You're gonna hear people in the background, you're gonna have to... [Laughs]

GP: [Laughs] that's okay, we've got a child crying out in the background.

RB: [Chuckles] But the faculty is the first thing that stands out in my mind because no matter what your mission is, no matter how excellent your curriculum is, no matter your goals, or the state that you live in where the state, you're aligning your goals with the state, and for that matter, having the word of God in our possession which influences what we teach, even if you have all of those pieces. If you don't have a sound faculty, you're at a loss, it's not gonna work. And so, the team, the chemistry of the team, is crucial. And then I think that, in answering that question, I mentioned the other pieces that are also very important which would be the fact that we have a strong statement of faith as an entire ministry but as a school as well, a strong curriculum; those would be, those would be essentials. I would say the other piece of the puzzle in a Christian school, probably in all schooling, but in a Christian school because of the demographics of the families that come and their desire to be a part of the school, a community that includes our families I just think is another strong piece. And as I'm saying all of this two things are 
gonna happen, one I'm gonna be encouraged by things as I think about it, and then I'm gonna think of all of the holes we have that we need to fill. [Chuckles]

GP: That's great. It's good to have honesty as we go through these. If I could maybe build off of one of the things that you mentioned, the first, and it sounds to me like the foremost in your mind, when you say faculty do you also mean that there should be a strong faith element, a Christian faith element among the faculty, kind of a "if we don't have this then we can't have Christian school perspective"? Meaning they should all have obvious Christian faith and a walk that's real.

RB: Yeah, I think it's a little, because, because obviously some individuals come to know the Lord much later in life, there is the possibility that you end up bringing staff on who maybe are not mature Christians.

GP: Mm hmm.

RB: It doesn't mean that you don't bring them on but there should be something in place to mentor those younger teachers, rather their young in age or young in their maturity level in Christ. The...the student body especially at the secondary level, the student body is close enough in age, some of those older students, that if you, you know, think of some of our specific teachers that just graduated from college and then step right into a teaching position, they are close enough in age that we have to be strong, not just in their maturity level in general but their Christian maturity, it needs to be there and if it's not there has to be mentorship and so, I just, yeah, and part of that is because so much of the teaching that is going to happen doesn't really have a whole lot to do with a curriculum.

GP: Mm hmm.

RB: It's relational, and so, yeah, that's just, that's strong. I think in the past one of, you know, big questions when we would hire people here is well, "What church do you go to? And what service do you do at your church? What is your ministry at your church?" I mean it was everything short of saying, "Well, can you bring us a bulletin from the church you went to on Sunday?"

\section{GP: [Chuckles]}

RB: "'Cause we need to be sure that you're in church." I, I am finding it's much, much deeper than that.

GP: Cool.

RB: Anyway, I could embellish on that.

GP: I would just encourage you as we go into it, I know some of these questions are tough but there's definitely common thread in what you just said about faculty and I think of, like, my first interview with D. Bruce Lockerbie, he mentioned his old mentor, Frank Gaebeline, saying in his very intelligent way, "the sine qui non" which is Latin for "the without which nothing" of Christian school is, "No Christian school without Christian faculty." 
RB: Mm. Mm hmm.

GP: So, just be encouraged, the threads are there and you know it's cool how God brings all of the thoughts together.

RB: $\mathrm{Hm}$, it must be obvious.

GP: Yeah, what specific needs of students in this generation stand out to you as unique or even different from past generations you've worked with in, in schooling, specifically Christian schooling, but I think we could say, really, any type of student, Christian or non?

RB: Uh, say the very first part again.

GP: What specific needs of students in this generation stand out to you as unique or even different from past generations?

RB: $\mathrm{Mm}$. Mm hmm. The word that came to mind when you started the sentence, the question, the first time and then when I had you repeat it, the same word came to mind and that is, authenticity. [Long pause] Whether in a Christian school or public just the generation of students that we have, I don't think we give them enough credit when it comes to being able to discern authenticity. We are very careful when children watch TV at an early age because we want to be careful that they know the difference between what is real and what is not real and there's a lot of developmental studies on cartoons and what should happen in cartoons at an early age. I think that our students can spot a genuine heart and can spot an authentic Christian and just authentic teaching in general. So, my point is, as I recently spoke to the staff about positional authority, we don't live in a society in general, that respects positional authority. I know the question is about students but students are basically becoming whatever society is forming, and they learn that from adults and authority figures. They have learned to not respect authority because of a position that they are in. They want real relationships, and we see that through social networking. The reason that they are having these shallow relationships that we're talking about right now is not because they want 250 friends with shallow relationships. I believe they're looking for a deeper relationship, and so they just keep going from person to person. So, they want genuine relationships, authenticity, and, yeah, and I think those are things that I think they want, now I think there's also a list of things that I think that they don't realize that they actually need and that would be what we're offering here at a very young age which is they need to be grounded. We need to be providing them with the thinking and teach them how to think and how to think from a biblical perspective which is a challenge because if you're not a Christian and you're trying to teach a Christian from a biblical perspective that's challenging but it can be done. And so by the time they make a commitment to Christ, they've learned it.

RB: And so, a second grader is not a mathematician but it doesn't mean we don't teach them two plus two like you start engraining them with the information. So, I'm kind of going off here...

GP: No that's very good, that's very good. 
RB: in different directions.

GP: Again, a common thread to encourage you to keep us going along would be that other people have said this as I've interviewed, to think biblically, think Christianly and you know to share with you maybe a little bit more for the sake of this recording and just our encouragement as educators here at Lititz Christian that would be, you know, I myself was taught Christianly in Sunday School from the time I was maybe eight years old, nine years old, and then didn't come to a real faith until 19, so it was great because by the time I "caught it" so to speak in my heart, I had all the head knowledge.

RB: $\mathrm{Mm} \mathrm{hmm.}$

GP: My wife on the other hand wasn't able to know how to think Christianly, grew up in a, you know, let's say for the sake of a better word, pagan home if you will and um, and then became a Christian and had to read, you know, feverishly read the bible to come to a knowledge of that Christian thought. So, but of course the Holy Spirit helps too but I think we have great responsibility here...

RB: $\mathrm{Mm} \mathrm{hmm.}$

GP: ... to uh, do what you're saying, so, thanks. Question three: identify two or three necessary changes that teachers must make to reach students in the 21st century.

RB: [Long pause] Students in general or, or at a Christian school?

GP: At a Christian school.

RB: Oh, okay. [Long pause] The first thing, you're saying changes that they have to make, right?

GP: Mm hmm.

RB: Okay, I'm gonna answer it. I don't know if it'll answer it exactly how you're asking that question.

'Cause a change would mean that they're not doing this and I wanna hope that they are and that would be. Yesterday, Jeremiah Kleylein spoke, are we allowed to say names on this?

GP: That's gonna be fine.

RB: Jeremiah spoke in chapel, and I'm just gonna be really blunt and say Jeremiah used the phrase, "Holy crap" okay? I cringed. Have I said, "Holy crap"? Yup. Have I personally said worse than that? Mm hmm, I have. But I, I know when to say what I'm gonna say hopefully. I use my filter. And I think it comes with maturity of knowing when to say things, however, even though that made me cringe, [pause] Jeremiah, speaks the language of our community and again, I am not affirming that we should use poor language, if children use poor language. I'm not saying that we should do what children do to have them understand, but my point is he is in touch with today's students culturally, and he could use words and he could use examples that if we as educators are not in tuned to we are losing opportunity to build those relationships with them. Now, I'm gonna clarify this too and you may need this or you may not. I don't think that every staff member is called to have the same relationship with the students. It's 
different, and when a student is needing a very authoritative figure who's going to be no nonsense, and students know when they need that, then maybe they're going to go to Faculty Member A, and that's their personality and they shouldn't change that and they're going to reach Group X. But, there's going to be a large population who need teachers to understand their culture and that includes their lingo that includes what they watch on TV that includes some of the abbreviations they use in texting. Like those are the students, I mean, those are the faculty members that for most of them are gonna be able to connect. So, to answer that question, the teachers need to stay informed of what's relevant and what matters to the students. When our Japanese exchange students come, we try to learn about their culture and how their parents treat them and how they're expected to behave in school so that we can connect with them better so that we understand better. So, the older teachers who have been doing it for quite some time, they put themselves in their comfortable little world of, "Here are my students, I'm gonna collect their papers and gonna grade it tonight" and they're not, not in tune to the whole student. An example would be, we have home games here. We have home soccer games that start at 4:00, there's not a good enough reason for our faculty to not attend, at the very least, one game a season. Why would they do that? Well, not because it would be expected but because Jimmy's playing in the game, and if I want to connect with him tomorrow, I need to know about Jimmy's world.

GP: Mm hmm.

RB: So, yeah. I guess, we could use the word change there and say about our own personal faculty, change how you think about, no let me re-say that, just keep, they need to keep changing. They have to change with the culture and with the times and be relevant and understand today's students.

GP: Is there another word that you'd prefer over "change"?

RB: I think the word is change, and the word is in this particular example that I'm giving you is always change. Change, change, change, change, change. There has to be change. If there's not change, there's a problem. Change. And, if you're not change, change just to change.

GP: [Chuckles] Change!

RB: You know if there's not a reason to change. You know, the whole thing of like, if it's not broke then don't... what is it...fix it?

GP: Don't fix it.

RB: Okay. If it's not broke, maybe we should consider breaking it. [Chuckles]

GP: [Chuckles] because maybe it's been sitting in the living room too long.

RB: Because, exactly. Break it so we can do something else. So, yeah, so I don't know if I ending up answering your question.

GP: That's good. Yeah, you know it makes me think of the Apostle Paul and his talking to the Greeks and basically saying, "This statue to the unknown God, let me tell you who that God is." You know, he spoke 
in their language. He had to have studied their culture, he had to have been there a little while probably knew their customs. I think the same thing for our kids. We need to know what they're doing, what they're thinking, what their mediums are.

RB: Mm hmm. Yeah.

GP: Yeah. And be able to, at least generally understand, how the other half, if you want, of their thinking world is involved with texting or media or you know, music or what not. Not that we can't speak against it as we did for the sake of this recording...

RB: Oh absolutely.

GP: Speaking against misuse of social media.

RB: Inappropriate.

GP: Inappropriate use of Facebook. So, yeah. It was a great example.

RB: And Gabe, I wanna, I just wanna, when I was saying the word "change" over and over again, and I know that you and I both know this but for the sake of the recording, and the one thing that doesn't change is the truth.

GP: Do you believe the ways we bring it out might change.

RB: Absolutely.

GP: But the basic message.

RB: The way we did it in 1978 is not the way we do it now.

GP: Alright, question four. What technological needs do you see as most essential to be taught and used in the 21st century Christian school?

RB: [Long pause] I am... weeding through my desires...

GP: Mm hmm.

RB: ....and, and what I should be answering...

GP: Mm hmm.

RB: ...which are two different things. But at the end of the day, [long pause] we can't answer that question and we can't even teach through technology or using technology... I'm gonna talk a little bit and then, then you'll end up getting a statement out of me.

GP: Good. 
RB: 'Cause I know you're anxious to write too. You can't look at today and you can't look at even next year and I know many times people put together like a five year plan which is actually much too long. [Chuckles] It has to be shorter than that when you're putting together a technology plan for a school. I think you have to look even beyond that and think, "Where do these students need to be when they finish secondary school and enter the next higher level of school?" If we don't look that far ahead, then we will always be outdated. We will be outdated before we even upgrade things. Okay, I'm going into specifics now, however, we don't know where our fifth grader is going to be, what's going to be required.

GP: Okay.

RB: We're not gonna know because it's so far ahead.

GP: Mm hmm.

RB: I mean we're talking eight years.

GP: And technology might totally evolve.

RB: Right, by then the chip will be, you know, in my forehead.

GP: Oh no. [Chuckles]

RB: [Chuckles] Gabe. But...

GP: End of the world.

RB: But my point is, so the goal is to always have them ready for when they leave here and they move on.

GP: Yeah.

RB: But that's so far ahead that all we can really do is work within a smaller time frame and goals. And so because we have phenomenal companies who are, or are laying things out in front of us all the time, this is the newest thing, this is what you need, this is what you need, this is what you need. I don't always believe that. I don't believe that everything that's laid out is what we need. You and I have the same type of smart phone, we don't share it but we have the same phone.

GP: Mm hmm.

RB: We don't need all of the things that this does. [Chuckles]

GP: [Chuckles] 
RB: And you can't argue with that. We don't need it, and I think that there is a lot out there that we think that we need. The smart board is such a good example of that technology. I know I'm getting too specific, I'll go quickly here.

GP: No, it's okay.

RB: But, you know, like, that comes out and so for six years this is the hot thing. Okay, and so everybody needs smart board. Okay? Smart boards are phasing out now. So...

GP: Mm hmm.

RB: ...my point is that, it's all, it's a utility, it's like the electric, you use it and when you're done using it you turn the light off and you never get that electric back, you never get the cost back. You used the electric, it served its purpose, you turn the light off, done. And that's how technology is to me. You make a purchase, you purchase tools and technology that help you reach your learning goal. It's just a tool. I'm saying utility and that's not the exact word but utility works. It is expenditure, it is, and it's disposable, if you will.

GP: Mm hmm.

RB: [Chuckles] it's just something that you use and it helps you get to where you gotta go, and when you're done with that you get rid of that tool, and you get another tool that helps you get to the next level. So all that to say that is the role of technology, in my mind, for educators, for learners. The way that technology works and the way that our children's minds work are unbelievable compared to the way our minds worked when we were in fifth grade or seventh grade. It's just a whole different time.

GP: Mm hmm.

RB: In twenty years, if the rapture doesn't come, cause I hear it's coming.

GP: [Chuckles]

RB: It will be totally different again.

GP: Yeah.

RB: But if you and I wouldn't have played Atari, if we wouldn't have had the Atari age, then we wouldn't have had the Nintendo age, and we wouldn't have had the Wii right now. We wouldn't be to the most updated... but when we played Atari, we had no idea that one day we would be there.

GP: Mm hmm.

RB: But, so the same thing with computers and technology in general whether it's a camera, a projector, whether it's a telephone, an iPad, because they're all technology and they all are tools. We forget we forget that. We forget that a recording device that we're using today is a piece of technology that schools often forget and we think- computer, smart board- that's our technology. Well, no, it's much 
bigger than that- but they're all tools to get to where we want to go. I just think of my daughter taking, pictures, she loves photography. The goal isn't to work a camera, the goal is to get a beautiful picture and the more she knows about the camera and how to use it, the better her chance of getting the photograph.

GP: Mm hmm.

RB: So. It's just a tool, and I don't even remember the question anymore because I've been talking so long.

GP: No, it's good. So, yeah, again, a lot of common threads using the tools appropriately, maybe could we say then, boiling it down to teaching students how to use the tools in order to be able to better communicate through technology, really, what they desire to communicate?

RB: Mm hmm. Sure.

GP: Again, bringing up conversations with other people, one interviewee and I talked about how we both took typing in high school and that served us into the computer age and I took typing on an IBM...

RB: How about it?

GP: ...you know, electric typewriter that was in 1991 or ' 92 , then boom the next year college hit and I was amazed at the fact that I could email my old classmate, now an alum from my high school, while he was at Purdue and I was at Ball State which were hours apart.

RB: $\mathrm{Mm} \mathrm{hmm.}$

GP: It was a big deal then.

RB: And now we're skyping.

GP: Do you think that there are key issues that divide students and teachers in the 21st century? I know we talked a little bit about that, but maybe we could go specifically...

RB: It's probably the cultural issues. [Long pause] Yeah and I don't always think, Gabe, that it's the teachers fault, let me just back up and say that, um...

GP: Mm hmm.

RB: I just heard a radio station yesterday, they did an advertisement about, "Summer's coming," and, "Summer's coming," and they have a whole bunch of kids in the background say, "Yay!" Um, "You're gonna be going to the pool!" And the kids all say, "Yay!" And, "You're gonna go on vacation!" And the group says, "Yay!" And, "You're gonna have cookouts!" And the kids say, "Yay!" And I don't even remember what the commercial was for but the very last thing is "And then it'll be time to go back to school." And then the kids all say, "Boo!" 
RB: And I, I just heard it yesterday I think or the day before yesterday. I thought, wow, thanks. Thank you society.

GP: Mm hmm.

RB: TV, media, they set up a no win situation between authority and children and then to be specific for us it would be between students and teachers. At home its between child and parent but our culture, our society, just sets up such a negative, like they've helped put those walls up and so for the teacher, they don't, I mean, they haven't even opened their mouth, they haven't even met a child, a student. They walk in the first day and there's already, "Teacher's bad, gives me work, boo. I'm not swimming." Like, [sigh of disgust] so my, my point is we have to work hard to undo that. At the end of the day, the shame of it is that it's the parents fault. It's our fault. I'll put myself in that category because we allow whatever we allow to be heard on our radios, and on our TVs and in our movies and in the conversations of our children at a young age. We allow it. So no longer can we trust the Disney channel...

GP: Hmm.

RB: ....because the Disney channel is going to teach your sixth grader that he or she should probably exchange a kiss with another sixth grader in front of their locker before homeroom in the morning because that's acceptable. So, we trust Disney to have a program for our children they watch it, and then that just cultivates their mind, that's how they think. So then they come to school and we say to the sixth grader who likes the other sixth grader, "You can't hold hands." So we're the bad guys. And really we're just, we're, you know, abiding by what we believe is God led and what is right and we're at a loss. So, we have to work very hard to become relational, to earn their respect, so that we can spend some chips and have them listen to us, trust us more than they do society. And I think that's why you end up seeing a turnaround by that twelfth grade year. In twelfth grade they start to mature enough, they're getting ready to step out there in the world, and they start to understand, "You know what, all these people who have been trying to tell me and guide me, they've been right." And we see that all the time.

RB: I'm gonna say that's the big one to me.

GP: So, do you see possibly then some kind of need for Christian schools in the 21st century to make a greater effort to uh, appeal to parents on the notes that you've been talking about.

RB: That's exactly what I was just gonna say.

GP: That's good.

RB: It's, just sure the parents know what you're saying from the school.

GP: Yeah.

RB: Like make sure that the parents know that you may be saying something that contradicts with what's going on at home. For example, we have parents who smoke, and their children come to school 
here. For a teacher to say up front "Your parent shouldn't smoke, that's bad." Or for us to not even say they're bad but, "People who smoke are bad." That's what Christians have taught their children. No, you know what let me speak Christians in our area, where I grew up. Okay? In this society here, in this community here, "People who smoke are bad." No parent has probably ever said those words but that's what they are teaching. So do you say that in a classroom? Do you say...do you imply that even? Well, if you're going to, you may want to communicate to the families, "Hey, we're talking about smoking. The effects of smoking. Maybe at your house, you have a smoker, we just want to keep that communication open." Because if we're criticizing what's going on at home, even though we can say, "Well the word says this." You just broke; you've just burned a bridge.

GP: Yeah.

RB: Does that make sense?

GP: Yeah, yeah. It's, you know, Paul's admonition. "For grace we have been saved by faith and not of ourselves so no one may boast..."

RB: Exactly.

GP: Maybe I'll integrate the word, "...so no teacher should boast."

RB: Exactly.

GP: So yeah, kids need to see that more and more. Disclaimers, you know?

RB: Absolutely. Absolutely.

GP: That may be a great, totally other thesis to go on one day for the Christian school. What specific steps do you feel then must be taken most quickly to bring about the sort of learning environment you've talked about in the 21st century Christian school? I mean if you were to instruct another head of school, like, "Hey here's my advice. Here are the three things that I think you could take really quickly into effect to bring about this type of learning environment you've been discussing for a while now."

RB: [Long pause] Well, two are coming to mind quickly. The first one has several bullets underneath just the first one. I'll just say that and give you one. For example, and I know I'm gonna be repeating myself a little bit, faculty is crucial. Be sure that you're hiring the right person. Yeah. So, that's a bullet under faculty. You know there's faculty and then okay, what about faculty? Well, when you hire new faculty, it's hard to get rid of them.

GP: Hmm.

RB: That sounds really unprofessional, sorry that I just said it like that, but you're in a bad spot. So, anyway, faculty first. Assuming that it's a Christian school, did we say that? 
GP: Definitely.

RB: The second one again has to do with faculty, so I'm kind of giving you, and it would be the developing of the faculty. Keeping the faculty current. Keeping them aware of the new trends of education, what to filter out.

GP: Mm hmm.

RB: Again staff development just has so much to do with them, and we talked about the culture, the knowing the students, the relationship. Again, it all ties to faculty, I can't help it. [Chuckles]

GP: Mm hmm.

RB: It does, just kind of all goes back to faculty. The second one would be, and I referenced this as well, would be to build a strong community base with the parents. Knowing the community that you live in and knowing the types of families is critical. And you know that from being in several different states. You can have the same goals in the end, but the way you get there is gonna be different in each place. We're in Lancaster County and its quirky and so the things that you try are maybe not gonna work someplace else. So... faculty, community of-of parents, would be the top two things. And then the third one, I'm gonna go ahead and this is really where I think this one even falls in this, not everyone would agree, would be leadership. And even though its third on this list, I still consider it to be imperative. You can have strong leadership, again that's probably why I put it third. You can have strong leadership but if the faculty's not right, what are you gonna do? That's who's affecting the students face to face every day. You can have an outstanding faculty who's doing their job and have leadership that's not. That can work. There may be a cap. It may only get to a certain point but if I had to choose one or the other, I want the faculty to be outstanding. And I'm saying that from experience of the last year personally. I've just gotta be sure that no matter what's happening administratively, every single day the bus is pulling up and the kids are getting out and they're going into their classrooms. We have to be sure that they're strong. Again, in the end it's gonna catch up with them. If leaderships not strong in the end that will catch up with them, but that's first and foremost to me would be faculty and then the parent community and then strong leadership. I think you asked for three things.

GP: Yup, that's good. All of those are excellent. So, you certainly have keyed in on faculty being imperative to growth in Christian schooling. If you're involved in the hiring process, what qualities or characteristics do you look for in applicants to provide students the type of education, Christian education that you've been talking about?

RB: [Long pause I'Il keep this one short.

GP: That's good.

RB: Basically saying, I'll just give you three. One is a no-brainer but they obviously have to have a relationship with Christ, one. Two they have to be qualified, and what I mean by qualified is not just that they have the degree. 
GP: Mm hmm.

RB: And then the third one would be, would be the chemistry for faculty, if we're just talking about faculty, right? We're just talking about faculty? The third one would be their desire to not necessarily teach a curriculum but to be an educator and a life builder. And their desire would be to empower these kids. Yeah, that's, those are the three. They have to be qualified, they obviously have to be a believer, but those two aren't enough. They have to have a passion to empower these students and be willing to build relationships with them. That's critical. Oh, that's critical. But, you have to have all three of them. You can't have just two of those. You can't just be a believer who wants to build relationships; we have an individual who wants that. We have an individual who wants a job here because they meet the qualifications because they're a Christian and they love the students, they do. I think they genuinely love the students but academically they're not there. So, I'm not hiring them.

GP: Yeah.

RB: Now something, yeah, I mean, the list could go on. Because there is chemistry, 'cause you could have someone that meets all of those but doesn't get along with peers and their colleagues.

GP: Mm hmm.

RB: Well, then what do you do with them?

GP: Yup.

RB: So, and I'm only saying this for the tapes sake, for the recording's sake, I just wanted to go back to clarify something and that is that we have some exceptions to something that I said to you earlier, and I wanted to say it then and I didn't when I was talking about Jeremiah and culture and that teachers need to know the culture and the lingo. I was saying to you that there are sometimes exceptions. For example, on our staff, we have a math teacher who would find it very difficult to hang with the lingo and he's just maybe a little eccentric, and yet he is doing his job, he is delivering what he should be delivering, and he is respected. He is in a position where if he tried to be something different then that it wouldn't work.

GP: Yeah.

RB: And so I just wanted to clarify for your sake too just so you know, I don't think everyone needs to fit into a particular mold to be effective and I think I said that when I said that I think we're not all called to be the same thing to every child.

GP: Yeah, you mentioned authenticity as a key word I actually wrote down and genuine. Can you tell me about a time or maybe it's a collection of times that felt most positive about your work as a Christian educator and that you knew your goals and your values were just being met? Uh, hitting a home run so to speak.

RB: [Long pause] Well, I can give you a really fresh one. 
GP: Good.

RB: [Long pause] In all, in all the questions that you've asked so far there is a word that I didn't say and it's because it doesn't hold the same weight as everything else. It's something that comes in later when everything else is in place this comes along side to make, to make things happen and the word is "a system". Okay? I think a system is crucial to an organization, any organization, and here we need lots of systems. So, it's important but as you can see, a good system with the wrong faculty doesn't work. A good system with the wrong leadership, doesn't work. A good system with teachers who are culturally diverse or culturally, you know, aware of their students and have good relationships, it just doesn't work. So, my point and prefacing it with that is, watching, listening to our athletic director, our fine arts director, and our spiritual life director, listening to the three of them at the recent meeting we had with our new exchange students, watching them get up one by one, seeing our secondary principal welcome introduce, like do an outstanding job, looking around the room from, you know I'm gonna be like, give you specifics okay? This is crazy. From home-made muffins in the back to balloons to families who would've never even attempted to have exchange students come to live with them, to Mr. Sugisawa from Japan who is trusting us with this relationship. Just looking at that whole experience, looking at these new children coming in, sitting there, I just don't think I could've been any prouder, and not in a sinful way, but just proud of who we are, proud of a team that worked together to bring this together and I just showed up.

GP: Mm hmm.

RB: And so this is very personal because three years ago that situation never happened. We never even had one of those days. Secondary principal comes, we do some brain storming, and we work together. He and I put it together for the first year, second year, I just show up. I don't say that cause I'm lazy and I don't wanna work but it was just such a good example of how the system works. We work as a team. It can work. We work as a team. We brainstorm. We bring in families, volunteers, there's that community piece. To see these directors get up and speak and hear them and think, "OK this one was green when he came in and look how he's developed." So, yeah many goals, many goals were met just looking at that, that event. Just looking at that one event, many goals were met.

GP: Mm hmm.

RB: From community, I just said it all, from community to seeing that the staff member was mentored by our secondary principal to be able to come to that level of speaking to them, to enhance this relationship that is very evangelical with Japan and then to have [Chuckles] our National Honor Society represented and to see what they're doing in this collection of supporting fun- it just was, it was the epitome of how just me sitting back watching going, "This is it. This is it. This is how it goes."

GP: Mm hmm.

RB: That was cool for me. 
GP: Mm hmm.

RB: Very cool, very cool.

GP: Yeah, and to comment for the notes sake here, being the secondary principal involved with that, you know, it's uh, similar for me. So, second year there I was too, even maybe being a little closer to the action then you get to be in your role [Clears throat] and honestly it was quite easy this year to see that come about. I think empowerment. I think, discipleship even those we lead so, again maybe even for the notes sake here, for my sake, potentially a thread for a doctoral thesis: Empowerment in the Christian School. Discipleship, you know. The ease and the grace of discipleship. We'll see if those are the words we use later on but thanks for sharing that.

RB: And that's, that's what it really is. And you know as you continue to lead and again, cause we're recording this, that... you and I should be happy to leave this place every day and not receive one kudo about what we did today, but if someone else gets all the glory but we really know that we're the ones that were behind then you know what great. Great. Our sinful nature is not designed for that and we have pride. Okay, go ahead.

GP: Are there specific people or events that have shaped the way you view Christian education and relate to students and faculty?

RB: Wow.

GP: I mean a couple that maybe just stand out.

RB: Mm hmm. Yeah. [Chuckles] Here's the surprising thing that I'm gonna say. I'll give two answers. The first one is, yes there is an individual but the individual doesn't teach in a Christian school, they teach in public education.

GP: Cool.

RB: Go figure. How can that be?

GP: [Chuckles] Mm hmm.

RB: [Chuckles] you're testimony is your testimony. Relationships are relationships. And I know from all of my answers if you were to give this to somebody else and say, "What's important to this guy?" And they read all the answers, they would say, "Okay, obviously relationship is what's important."

GP: Mm hmm.

RB: It doesn't matter if you're in Christian education or public or wherever you are, its relationships. That's it. At the end of the day, that's what it is. And we tried to make the word, we try to make God's command, or Christ's command on us so complex of like what the Christian life is to be. It's not that, it's not that complex. We're just supposed to love them. That's what we're supposed to do. We're supposed 
to love them. So my point is the person who has shaped that, I would say one of the people, and she doesn't realize how much she did. Actually you got to meet her, was the technology coordinator for the Warwick School District and that's Doreen Packer. You remember her by chance?

GP: OH yeah.

RB: Mm hmm. Yeah. I just described all of them. Okay, so there's a Christian working in the public world who helped to form that. Schools like Oaks Christian and Valley Christian, reading, I believe its uh, Cliff Doherty's book about Valley Christian... those schools, not even hardly knowing very much about them but what I know of them, they have been formative, they have, they have said to me, "You do not need to be so standard." Being able to look back twenty years ago and see where Valley Christian was in dire straits and then to see where they are, that's, that's encouragement to me.

GP: Briefly, what role do you see parents playing in the 21st century Christian school? Maybe better put, maybe what role do you think they should be playing in the 21st century Christian school?

RB: What role should they play? [Long pause] Well, that's the hardest question that you asked me for me right now anyway. What role should they play? Part of me wants to answer this question like this. Has it been for other people too?

GP: It's been tough, a couple people passed on it at first.

RB: My quick response is it should be the same role that they were supposed to play from the beginning of education.

RB: [Chuckles] Yeah, from Deuteronomy. Yeah, they're role has not changed. They are the primary responsible people for their children and their education. So, it's their responsibility which is why they want the Senate Bill I to pass that they can decide where the money's going. Okay, but, their role is to support, assuming that, assuming that administration and faculty and curriculum is all truth and there's no discrepancy that matters they should play the role of being, its actually more than a partner. We call it a partnership, it's a little bit more than a partnership like in the end, and I don't think the Lord... I think, I think so I don't wanna say that this is truth, but I think that at the end of the day if the Lord is standing, if they're standing in front of God and God says, "Ok, we're gonna go over this checklist of things that you were supposed to do while you were caring for my child. Okay. Education?" I think he grades them harder then he grades us, the educators, if he's using the same rubric. He would grade them harder.

GP: Mm hmm.

RB: We're still graded and we are still responsible for what we say and we do in the mission of the school and et cetera. But it's not that Disney philosophy that I say which is, "It may not be my fault but at the end of the day, it's my responsibility." So, if we screw up, sorry, I didn't say "Holy crap." I just said, "Screw up." If we, you know, don't do our job as a school and the parents have entrusted us to do it, I think that they're held accountable. Like I said I have no, I have no uh facts or anything, I just think that 
at the end of the day, they are responsible until those children become adults, they're responsible. So, what's their role? Their role didn't change. They are primarily responsible for the education of their children and who they allow their children to be educated by. So that's assuming that, that's assuming that everything in the relationship with a school or institution is all good. So, if we got into specifics their role would be the list of the things that a parent should be doing and that would be being engaged in your child's education by being supportive, but i don't think you want that detail, I think we're at a broader answer for this.

GP: Yeah, not today. Yeah but that's good.

RB: Like, they should be doing their vocabulary with them. [Chuckle] No, I'm just kidding.

GP: Yeah.

RB: So.

GP: Cool. Alright, well, quite a few questions you've answered very, very well and completely. Thanks for doing that and I just wanna maybe ask one more question as we wrap up. Are there any things, thoughts that you need to share with me that regard 21st century Christian schooling, maybe something that you're really passionate about that we've not talked about or a book that you've read recently that maybe you would turn me toward? You know, maybe just one or two things there.

RB: Well, I'll be I'll be honest. I'll be honest and tell you what I'm working through in my mind right now. And that is, that is God giving the vision [pause] I'm sorry that I'm kind of staggering here. [Long pause] When God gives vision doesn't he also give provision? And so, well one of the books that I'm reading is called "The Sower" and this book is about providing resources, primarily from a monetary perspective and of course I would bring money into this conversation because that's probably what, you know, fills my days, right now. But this book is about should God's people be the ones to provide the resources for, for Christian schools as opposed to going out to the public in general. And so some of the things that I'm reading I think I'm agreeing with, some of them are new thoughts so I'm not really sure if I agree yet.

GP: Mm hmm.

RB: [Long pause] So, it kind of tells you where my heart and thoughts are right now which are like, "God, do you, are you telling, are you telling me there's, are you telling me you want a school and if you are but you're not providing resources, is it an error on our part, on my part? Is the vision really from you? How do you decipher that? So anyway, I'm sharing kind of professional and personal, personally kind of like where I'm wrestling a little bit.

GP: Mm hmm.

RB: Yeah, that's where I am with that right now. [Long pause] Yeah. And the other thing would be, I shared a little earlier, just about the book by Cliff Doherty which is the story of Valley Christian and just what, the encouragement that that has been. It's called "A Quest for Excellence" and I, I just really 
appreciated that. I'm not being real clear here and giving you an answer, Gabe, probably because I'm processing and thinking a lot about, yeah I don't know that I even have some conclusions to some of the things that I'm talking about. So anyways, so I'm sorry, that's probably, that's probably my, my, you probably needed that answer and I'm not giving you a good answer there and I apologize.

GP: No, no that's good. I'm just kind of fishing for opportunities to add to my reading list.

RB: Yeah probably, they're very simple books. And again, because it's us and it's okay to be on the tape, you knowing where our ministry is, where Grace ministries is and the fragile state that it's in, that, that probably affects that answer the most. All of the other questions that you've asked, I'm sure something that may have affected maybe some answer to a degree but those were really about education whether we were connected to a church or not, this last one, there's, it's impacting me and my thoughts and my vision and so enough that I think that's why it's maybe even a little muddy.

GP: Very good. Well thanks for your time and it's been a pleasure to interview you. And, when we get this transcript together, I'll send you a copy so you can see some of the things that we put in and make sure I won't misquote you on anything. But thanks for your time today. I appreciate the opportunity.

RB: My pleasure. 
Questions provided in written response by Chris Cleveland.

$4 / 8 / 2011$

\section{Interview Questions}

1. What are the key elements that you believe should set Christian schooling apart from secular schooling in the $21^{\text {st }}$ century?

A. First, a Christian school should be fully committed to doing everything at the highest possible level, because if you are going to represent yourself as an ambassador for Christ, you had better do it well. I also prefer the term Christ-centered school as opposed to Christian school. Institutions cannot be Christian, only people can. What sets a Christ-centered school apart from a secular school is not the mission, not Bible credits, and not chapel. What should set it apart is the spiritual maturity of he faculty / staff / administration / board of trustees and their individual and collective desire to live out their faith in all situations.

2. What specific needs of students in this generation stand out to you as unique or different from past generations?

A. This generation has grown up with a great deal of instability, constant change, uncertainty, and an unyielding pace of life. This generation has grown up with the threat of terrorism. The economy has been unstable. They have seen their parents or their friends' parents lose their job and/or their home. The advancement of technology and the way technology has accelerated change and the pace of life is staggering and unsettling. This generation needs safety, security, stability, and peace. I actually think that all of the chaos of this world gives us, as Christian educators, a fantastic opportunity. What a great contrast we have to offer compared to the world. In the face of instability, chaos, constant change and a breakneck pace, we can demonstrate to students the peace, calm, safety, stability, and consistency of Jesus Christ. God never changes. Nothing ever surprises Him. His peace is the peace that transcends all understanding. As the world gets worse, God looks better and better, and that is a story we need to tell our students.

3. Identify two to three necessary changes that teachers must make to reach students in the $21^{\text {st }}$ century?

A. I actually believe that what teachers need to reach students today is the same things they needed 50 years ago. Teachers need to love what they teach, and more importantly, who they teach. A teacher loves their subject and loves their students then two critical things will happen. First, they will approach their work with tremendous passion. Second, teachers who love who they teach wan to invest time in the lives of their students. In a world that consistently sends the message to young people that nobody really has time for them, a teacher who is willing to lead a missions trip, go see a concert, show up at a game, meet a student before or after school communicates to that student that he/she is willing to give up their most precious resource: their time. It's not complicated, and I truly don't believe it changes over time. Love what you teach, love who you teach, have passion, and give of your time. 
4. What technological needs do you see as essential to be taught and used in the $21^{\text {st }}$ century Christian school?

A. The ethics of the internet. We need o be careful to not stick our head into the sand when it comes to the internet. It's not going away, and we need to teach students how to use it properly, and to develop an understanding of the unique ethical challenges that the pervasive nature of technology, specifically the internet, bring to the $21^{\text {st }}$ century Character, integrity, honor, and honesty are in short supply and high demand. If we can't instill that in our students as Christcentered schools, then who will?

5. What key issues do you think most divide students and their teachers in the $21^{\text {st }}$ century?

A. Again, I think what divides students and teaches today is what has always divided them...an unwillingness on the part of many teachers to be intentional in building relationships with students... a lack of willingness to try new ideas and being inflexible in the way they provide the education in their classroom...sending the message to students that you are only willing to educate them on your terms. Teaching is a relational skill!

6. Have you made any suggestions to teachers as to how they might change their teaching to reach today's students?

A. I haven't. I have always tried to address this issue in the hiring process. I think that either you can make the connection with students, or you can't. I can help someone learn more about their content area. I can send someone back to school to earn an advanced degree. I can help someone learn classroom management tactics. But, I can't teach someone to be passionate about what they teach and who they teach: you either have it or you don't.

7. What specific steps do you feel must be taken quickly to bring about the sort of learning environment you see as most beneficial for $21^{\text {st }}$ century students?

A. As an administrator, you have to find the balance between giving people time to improve on their areas of weakness and not waiting too long before you make a change. It is difficult. But hiring / dismissing is the single most impactful thing you can do to create the learning environment you want. When you get the right person, you need to do everything you can to support him / her. When you are convinced you don't have the right fit, you must act decisively.

8. If you are involved in a hiring process, what qualities or characteristics would you look for in applicants that would provide students the kind of education we've been talking about?

A. I think I have already addressed this one, but I am looking for people who are passionate about their faith in Jesus Christ, passionate about the subject they teach, and passionate about the agelevel with whom they work. Professionalism, punctuality, and a presence are also important, but of you don't have those first three, I'm not going to hire you.

9. Please tell me about a time that you felt most positive about your work and that your goals values in Christian education were being met.

A. As a young principal, I had a veteran teacher on my faculty who was mailing it in, and had been doing so for several years. This teacher had been teaching longer(39 years) than I had been alive. In fact, this teacher had taught me when I was in high school. She had been a great teacher 
earlier in her career, but she was sending the message that she was done and just biding her time to retirement. She was not updating lesson plans or tests, she was mean to the kids, and she acted as if she was untouchable. I made the decision to not renew her contract. It was incredibly difficult, but I knew I was doing the right thing for the students, who were no longer getting the type of education they deserved.

10. Without worrying about being modest, please tell me what it was about you - your qualities, capacities, decisions you made or actions your took - that contributed to the situation.

A. I pushed the discussion to not re-new her with my head of school. She wanted to come back for her $40^{\text {th }}$ year, but I just firmly believed that waiting even one more year was not fair to those students who would have her in class. Did she deserve another year or did her students deserve a better teacher? I wanted our students to have a classroom experience that was positive, and it was not happening.

11. What specific situations or events have changed the way you view education, the way you relate with students, parents, colleagues and others?

A. I have been blessed to sit under some great leaders who have influenced me significantly, but, having my children of my own has been a great motivator to view the decisions I make through the lens of an administrator and a parent. When it comes to the classroom experience of a child or a discipline decision, when I ask myself, "what would I do if my child were in that class or in that situation?” That brings a whole new level of thinking to any situation.

12. How can your methods for adapting to the needs of $21^{\text {st }}$ century be brought to the minds and methodologies of our current Christian school teachers?

A. I think we need to get much more serious about providing high quality professional development for Christian teachers. Unfortunately, I often find myself disappointed in the quality of Christian education conferences I attend. The secular conferences I attend are of a significantly higher quality. We need some strong national voices to speak on the importance, value, and need for Christ-centered schools of the highest quality.

13. What role do you see parents playing the $21^{\text {st }}$ century Christian school?

A. A critical one. Christ-centered education works best when it is a partnership between the home and the school. All too often, parents are relying on the school to have the hard conversations with their children. We make too many assumptions that parents know how to parent. I find that often times, they don't. Christ-centered schools need to invest time, money, and effort in ramping up their parent-education opportunities in the area of basic parenting skills. The investment would be well worth it.

14. Are there any thoughts on the need to transform education in the $21^{\text {st }}$ century Christian school that I have not asked but you would like to share with me now?

A. Yes. I am in my $19^{\text {th }}$ year in education; 18 of which have been spent in Christ-centered schools. I attended a Christ-centered school from Kindergarten $-12^{\text {th }}$ grade. I believe in and am committed 
to Christian education. However, I am disappointed in the number of Christ-centered schools that seem to use Christianity as an excuse to be mediocre in almost every other way. The word tells us that to believe in Jesus Christ, you have to check your brain at the door. We must create Christcentered schools that are unapologetically committed to Jesus Christ, but who are equally committed to an academic program that is of the absolute highest quality. I believe that Christcentered and academically rigorous are not mutually exclusive. In fact, I believe the two can actually enhance each other. The world has a lot of problems, and to solve those problems, we need a lot of smart people. But we also need smart people of the highest character in order to lead effectively. As Christ-centered schools and educators, we have a great opportunity to produce a generation of bright, passionate, Godly young leaders who can fill the void. But what we cannot do is reinforce the incorrect belief that to be a Christ-centered school is to be a school that takes a back seat academically. 
Title: Phone Interview with Dr. Jane Duffey

Date/Time Recorded: 4/6/2011 4:05:31 PM

Record time: 0:39:26

GP: Alright I'm talking with Doctor Jane Duffey from Norfolk Christian School and, Jane can you just tell me a little bit about your position at the school, what your title is?

JD: Right, I am officially the head of school at Norfolk Christian which means that most, well all of the administrative team is responsible to report to me and I am likewise report to our board of directors, and so yes, I am at the top of the chain of command for the school.

GP: I wanted to let you know before we launch into any kind of questions, what I'm interested in gaining are your thoughts on the development of improved learning environments for the 21st century Christian school and maybe as well how you've developed or hope to develop your goals in Christian schooling. The focus of my project is to develop a coherent set of qualitative insights that point to trends in Christian schools that have sensitivity to methods and matters of making or maybe having perceived ability to make a great influence on 21st century Christian schools. So first question, what are the key elements that you believe should set Christian schooling apart from secular schooling here in the 21st century?

JD: Wow, well of course even if it is 21st century we still can't lose the mission of Christian schooling, the fact that we are here to reflect God on earth. Well, as Christians we are here to get that message across to the children that they are born in the image of God and that becomes their job is to become like him on earth. And what does that mean to him, and to the children? So we're there to see that they understand that message. And then also, we talked about this today, you know, what is their mission? What, personally, how are they called? You know, what are they called to be here on earth? And we're here to help them understand and to discover what that is and to help them become that and that certainly is, is no small matter. We are, you know, part of a community and so we have to understand what community life means and of course, that has changed so much in this 21st century because you know, they speak at the Global Village and as Christians we talk about being ambassadors to the world. They truly are getting that idea of ambassadors to the world you know, probably the true sense of the meaning then they did fifty years ago or twenty years ago even. So I think that education in the 21st century, the Christian education of the 21st century has evolved greatly from what Christian education started out as in the, in the emerging years in the 60s. I think the scope of it has really enlarged quite a bit.

GP: Are there some...

JD: Key elements? 
GP: Yeah, maybe some key things that along with what you're talking about that really do set it apart from the secular school in your mind?

JD: Well obviously our whole framework for teaching and learning is still, it's still the Scriptures and its Biblical thinking. So, that alone sets us apart. You know we talk about the difference between, you know, secular humanism and a Christian worldview. That hasn't changed at all. Now the settings are changing, the settings, the world settings are certainly changing but that Biblical framework is not changing at all. That is the dividing point between a secular education and a Christian education. Yeah, there's still a division of thought of what Christian education, who Christian education is for. I've seen a lot being written about that. Is it just for kids whose parents are Christian or is it for, is it inviting in a larger audience? And then the teachers are still the ones responsible for delivering the learning experience within that Christian framework. You know, I think there's talk in that area but still it's the framework of delivering the education that to me, hasn't changed. Our methods change, the content areas are changing, you know, what we're teaching them is changing because the world is changing. GP: Mm hmm.

JD: But still, that Biblical framework isn't changing.

GP: Good, good. Well just to encourage you have some very salient similar points to other people that I mentioned that have answered that question, of course everybody has...

JD: I hope so.

GP: .... slightly different take on it but a lot, many of you are saying similar things just about the Biblical framework and that, so be encouraged there.

JD: $\mathrm{Mm} \mathrm{hmm.}$

GP: What specific needs of students in this generation stand out to you maybe as many unique or different from past generations you've taught?

JD: Mm hmm. Wow, the most thing that we of course notice a lot is the family structure that certainly has been changing: the single parent families, the disconnected families, you know the ones whose church community isn't quite as tight as it used to be, the two parent working or one parent at home working, the family structure has been redefined...

GP: Mm hmm.

JD: ...and so that's a huge challenge to us at school. How community itself is defined has changed a lot. Norfolk Christian for instance, used to be a fairly well defined community out of one church, and now we represent over 100 different churches and you know, that has really enlarged our view a lot and then it called us to respond in, in a different kind of way. So social, church structures, all of that has changed in the last few years or probably it's taken longer than that, it's my own view [Chuckles] has been enlarging. That has challenged us to respond accordingly. The needs of the kids, maybe it has a lot to do 
with the family structure and breaking down too, the needs of the kids have been changing, there seems to be a lot more broken, dysfunctional types of families, and then the kids are presenting, a lot of them are presenting emotional problems to us, sometimes greater learning problems because it's tied into those emotional disruptions in their lives. You know, that's, that's been problematic and challenging for the school as well. Other things that are changing are just the volume of information that kids are able to learn now, so we can't teach it all but how do we approach learning? You know, we've come, I think, you know, you talk a lot about facilitators of learning. We have to do more then, we have to teach more methods, more strategies to the kids, how to access knowledge because we can't teach all that knowledge to them any longer because the amount of it has expanded so much. And then you've got the whole world of technology. You know, there are more subjects that the kids are learning now just because there is so much more out there. Technology has really changed the face of learning.

GP: Mm hmm.

JD: ...both in methodology and in content. So, those are, I think those are all some significant changes in the education world.

GP: Speaking of technology, what technological needs do you see as most essential to be taught and used here in the 21st century Christian school? Are there two or three again that really just stand out uh, a direction of need?

JD: Well, I mean kids have to learn how to research obviously, they have to learn how to, for this quality research, what is good versus, I mean they're all kind of learning how to navigate the internet [Chuckles] in many special ways so they have to learn quality research. They're not going to really have to go to libraries, I don't think they even go to libraries much anymore, you know, a lot of it is navigating the internet and accessing materials that, that's one really important way but the other is also how to use technology wisely, to use it in God-honoring ways. There are all kinds of issues out there; you know how to be a discerning learner. That part, I think, has to be taught very intentionally to the kids. You know, "Parents make sure you put some kind of safety net on your computers." Now the kids have to learn how to use technology wisely and in ways that really honor God and I'm not so sure that we're doing that. I think it has be woven in all types of instruction but also taught specifically.

GP: That's a great challenge.

JD: Yeah, that is all a part of it.

GP: What key issues do you think most divide students and their teachers in the 21st century, if anything?

JD: Divide?

GP: Mm hmm.

JD: Hmm. [Thoughtful sigh] Wow. Now, you're talking, hmm, like social issues? 
GP: Maybe things that divide students and teachers to the point where it makes learning more difficult.

JD: Well some of it still has to do with generational issues, you know some, some of the older generations have a hard time teaching the younger ones because of, I don't want to say a post-modern type of thinking, but that whole relationship building. However, you know good teachers kind of got that all the way along, throughout the ages, but I think it's even more important now and kind of intentional. Some of these things can be taught: how to build a relationship with younger people and if it can even be instructional strategies you know constructing small groups in your classroom and you know, the cooperative learning, you know, that kind of thing cause all that is trying to kind of break down your classroom into do-able units and get them to relate to one another as well as you relate to them. That's, I think part of it, some of the dividing issues. I think it really has to do with relativism, you know, that sometimes our kids even though they wouldn't see themselves as thinking relatively. But some of these are good things to discuss for the teachers to discuss with the kids and it's not presenting everything as black and white to them. They're gonna have to learn that there are some indisputables in biblical thinking however we get at that is. It's really important to get the kids to see it that way. I mean, they can have great discussions about some of the social issues that are clear to us as Christians, you know, when you get to talking about abortion, and when you get to talking about homosexual marriage and that type of thing, but you've got to be able to talk about it first with the kids and not automatically just cut them off and say, "Oh, it's all bad, all wrong." You know, so I see it's so much more important these days to kind of create some buy in with some students because they are gonna question everything that you do.

GP: Have you made any suggestions to teachers recently as to how they might adapt and make changes to reach these more maybe modern students if you wanna put it that way?

JD: Yeah, I don't actually have to do that because there are teachers that are doing that already. Some of our younger teachers are coming in and they are doing that in their classrooms and they're being good teachers and so they're kind of persuasive as they share some of the things they're doing. I've got a Bible teacher who is doing some blogging in her class with the kids and allowing them to talk about some of those topics, and she gave them ground rules, you know, because this is open to view, parents can see it, I can see it, all types of people can see it. It's not password controlled necessarily so they know the ground rules. And they have been discussing some of these issues in very honest ways, but they're allowed to do that. So other teachers are seeing the results of that and they're looking at some of the kids discussions and saying, "Wow, these kids are really giving some thoughtful answers. You know, maybe they're not exactly where I am in my thinking but they're being, you know, relatively mature in their thinking." And so that's been, that has impressed the other teachers. So sometimes it's just a matter of other people coming and you can, you can point the teachers, you know, you can say, "Hey look what Elle's doing, it's really cool. You know you gotta see this." So in a way that, you know it's not top down, it's like, "Notice what somebody else is doing and..." And they're curious enough, some of them, to want to do that too. We certainly do professional development in some of those areas of showing the teachers how you can work with these kids. We've done the bible studies too and talking about the kids of this generation and doing the soul searching videos and talking about that. I think 
there's ways you can do that without just doing the top down, "You have to do this because you've got some of the older teachers." They're going to be very, very resistant to doing that.

GP: Mm hmm. Well you mentioned some strategies there in just bringing about the type of learning environment even among the teachers that you see as beneficial, are there specific steps, maybe two or three that come to mind that you feel could be taken quickly in any Christian school to bring about a more beneficial 21st century model?

JD: They've been talking about doing differentiation now for a good ten years coming out of the schools of education and yet we keep finding every year as we teach it, it still is like an "Aha" moment for a lot of teachers so, it never fails to amaze me how you can keep teaching some of the things you assume people ought to be knowing already and they're receiving it and then implementing that. I mean that, that's just an example of something that we've done over the last couple of years. Lots of the technology tools are easy to teach and get the teachers to implement. I think they're so intrigued as long as you give them support, you know, the material support to be able to do that, you know, you gotta give them the material-, the technology capabilities. That then is something that we've been able to do too. I understand you're gonna have some technology resistant people but for the most part that's been successful.

GP: Good. As far as um, you mentioned, your wording of a "Biblical framework", I talked a little earlier today to someone else and they're wording was "Biblical integration" and both of you are obviously passionate about that but from your point of view, how do you, what are the steps that you've taken or want to take to bring that to light in, at Norfolk Christian?

JD: Yeah, well, ACSI has done some of that for us but...

GP: Mm hmm.

JD: [Laughs] ... you know, it's just in the fact like, "everybody you've got to have your ACSI certification, and oh by the way you've got to do this course, you have the philosophy of Christian education." But, and actually that has been pretty helpful because everyone kind of goes on that journey alone...

GP: Mm hmm.

JD: ...A lot of our teachers do come out of a Christian college so some of them kind of come to us with that, then we've got the ones who have grown up in Christian schooling too and that's very helpful. They kind of get it from the time they've been in utero. You still have to do the talking about it and the reinforcing it, so we've done that in a variety of ways. One of the schools just read, "Teaching Redemptively" as a, as a school and they worked through that in their morning devotions. It took them about six months to do that.

GP: Mm hmm. 
JD: That's been great because they, you know, just do a little piece at a time and talk about how they implement that. It's just kind of a continuing conversation book. I mean there's so many different models. Of course, it's also required in lesson planning and in curriculum outlines and all of that sort of thing. So it is woven in all we do, but I don't honestly like the term "Biblical Integration", but I really do like the term "Biblical framework". "Integration" almost sounds sometimes like an add on, you know, it's not that you're choosing a Bible verse for that unit. So like, "That really sounds good." or "I've gotta find something that supports this." To me it's, you know, the eternal question, not the essential question, but what is the eternal question that's attached to what I'm teaching. Now what's the reason I'm teaching this from a Biblical standpoint.

GP: Very good. As you're involved in hiring processes, what qualities or characteristics do you look for in applicants to provide students the kind of education you've been talking about?

JD: Well right now I want them to be very mature.

GP: [Chuckles]

JD: I'm just in middle of doing lots of interviews. Well, I mean you're looking ideally. Of course you want that mastery of instructional techniques. You want them to come with all the tools. You know if you get them fresh out of college it feels like you're putting so much time and energy into them; although they've got all, just have the latest ideas. So, I just love that they've got experience and they really do have a tool box that's already kind of filled, that they know what works and what doesn't work but the other thing really is too that they understand the whole Christian education piece that they really get that. In both categories you've got some people that just are born that way just kind of God's gifted them incredibly, but I don't ever diminish the role of the school of education. You know, um the best thing often times in private schools you've got people that come with incredible content knowledge. You know they don't have to hire you necessarily with a teaching background or a school of education type background, but you know I find both things are important. So I'm really gonna give you three things: the content is delivery and it is then all wrapped up in being a mature Christian and understanding the importance of the calling. So, I mean that's like Super Man or Super Woman, that's what you're looking for. A Christian Superman.

GP: That's what we're looking for, right? [Chuckles]

JD: Yeah. That's what we're looking for. You have the ideals, so there you are.

GP: That's cool. Can you tell me about a time or maybe it's a collection of times where you felt very positive about your work and goals as well as your values as a Christian educator where you just knew that it was all coming together, you know, it seemed like you were hitting the ball out of the park so to speak when it came to those again, the goals and the values that you have as a Christian educator?

JD: Oh wow, hmm, that, that's a little hard because a lot of it has to tie off, a lot to your personality so if you're a perfectionist those moments come far and few between [Laughs]. 
GP: Mm hmm.

JD: Yeah, that's a tough one. I feel really good, you know, the last couple years after I handed diplomas to the high school seniors. [Laughs] You know its like; actually sometimes it's just so "Whew, glad you know he just walked across the stage. [Laughs]

GP: He made it.

JD: "And you know he didn't mess up the last six weeks but..." You know there is, obviously, a real sense of satisfaction when that happens or when someone is receiving some kind of a reward for a job well done and you know that you had a part in that. It's been nice for me to be in a place for twenty years so that I can, when I have kids come back and they say "Thank you" or "You know you were an important teacher in my life." Obviously we don't do it for somebody coming back and giving us praise. You know, we just can't do it for that because [Chuckles while speaking] we wouldn't get enough of that to sustain us. But it is nice when that happens. And you know l've had a few kids who have come back and told me that, and I have to admit that the natural man in me likes to hear that and it means something but more often than that, you know, God does in my quiet times to encourage me and say, you know, "Well done, well done. I'm glad you hung in there and did that." Specific times oh wow, I'm not good at specifics I'm more of a generalist. I mean I can point to graduation time and those, those high moments in the school's life when I know that it's been well done and we celebrate. Celebrations are very, very important.

GP: Good. Yeah, and again, you know, it's interesting to me already to see very common threads with you and others that I've talked to along these same lines that say, you know, stick with it and further down the road that you're going to have those opportunities to hear well done.

JD: Yeah, there are far more plotting on times that plot on, plot on, plot on...really, putting your hand to the plow and not looking back. There are far more times like that, you know, we don't really live on the mountaintop all that long and often so. The air is way too thin up there.

GP: [Laughs] what specific situations or events, Jane, may have molded or most shaped the way that you view education and the way you relate to students, colleagues, even parents?

JD: Oh yeah, I mean, there certainly are some very important people in your life that bring you to where you are that teaching, you know, one generation teaching another is really, really important. And we often look back and we probably see teachers in our lives that had, had huge amount of meaning. I mean I can still remember my third grade teacher and I, I never, well, they called themselves Christian but some of it, the ones I experienced, that they really weren't. But she really knew what differentiated instruction was like and it, it really stuck with me. You know, creating those learning experiences with kids, not necessarily putting kids in little rows and teaching, you know, lecturing them type thing. Even in third grade I can look back to that and still can remember that [Laughs]. You know there, I did have a bible teacher when I was in high school who I can still see her just talking about, you know getting into the word of God, and her face would glow. And, I can look back at her and thinking wow the word of 
God must be something really cool that I would like to get into that and have my face glow. You know that type of thing.

GP: [Chuckles]

JD: And then yeah I think one of the most important persons in my professional life was the middle school principal at Norfolk Christian who founded the middle school there. Her name was Cindy Meganson, and she was an incredible individual. She was the one who brought me to teach at Norfolk Christian. I think a woman who knew children better than anybody married that I knew, never had children of her own, but she understood the adolescent mind so much better than anybody that I knew. So, God clearly gifted her and you know showed me that was something I could aspire to be and to do. So yeah, there are some of those people that have those incredible moments in importance to you.

GP: What role do you see parents playing in the 21st century Christian school?

JD: Oh. [Deep exhale] I wish it were the same role they were playing in the 20th century Christian school, but I guess I'm gonna have to be more realistic than that. We still have, you know, a smaller and smaller body of moms. I think moms are one of the things that have made Christian schools work because we'd like a partnership of parents but ultimately that partnership tends to be more of the moms but they're still there, they're still important. It's just a shrinking body, and we really value our parents being in our school and not delegating everything to us because that would be exhausting, we couldn't give our kids the great experiences that they have if we didn't have that, the active parent partnership. It changed because I think that as schools have been more consumer oriented, the parents have treated us more like businesses, and you know there's not that same trust and the same relationship that there used to be in school, so we have to educate them more if they give us the time to do that. So that's been challenge trying to figure out how to orient parents toward understanding what Christian education is all about. There's a few that get it but again, it's just like shrinking body of mom's there's a shrinking body of parents that seem to understand what it's all about.

GP: So what role do you see them playing then with Christian schools?

JD: Well, certainly I hope they keep paying the money. [Laughs]

GP: Mm hmm.

JD: But it's, you know, I don't know if they're becoming more customers to us than they are partners. I think to me the jury is still out on that. It certainly is more challenging for us though, they're not just lining up and understanding what it's all about and, we're, we're just gonna have to convince them more and more of, about the mission, selling the mission of the school.

GP: Mm hmm. Is there a specific point that you can think of to go back to where that started to happen? The change? The shift from understanding, as you put it, to kind of needing to be convinced? Or have we just stopped doing such a great job of convincing? 
JD: No, I mean this might start to, you know, sound like I'm getting a little spiritual but I'm, I'm almost convinced that there is something altogether with what's happening in the Northern Hemisphere if you will where Christian education kind of began, but I mean there was sort of a second coming in the Christian education which was the 50s, 60s, and you know the huge growth of the small church schools that a lot of them have died off now but there, and um, because that same growth is now coming in the southern hemisphere. I think if you talk to ASCI people, they'll tell you that a lot of the schools are closing in North America they're growing like crazy in Africa and South America, you know in, in other places and that, that's where their growth is coming from. So, yeah, there's been a change and I, I, I'm, I've been very curious as to exactly what it is. And the quality schools seem to be surviving but the schools that weren't so great quality, they're not.

GP: Mm hmm.

JD: So there's good and something not so good about that at the same time.

GP: Mm hmm.

JD: And I, I'm curious; I don't really know exactly what it is. I don't know if there's a move of the Spirit that has just kind of died out and, you know, when people don't have that fervor any longer they're not so willing to sink their money in what you're doing and maybe again, they're not receiving the quality so they're so willing to sink their money in that either. I mean, we were so, when my husband and I started our kids in Christian schooling we were so dedicated to the cause of Christian schooling and I still am, but of course I can still look around. We put them in some very questionable schools. They got a lot out of those schools I have to admit but, their quality was very questionable.

GP: Mm hmm.

JD: So, yeah, I don't know. I'd be curious as to what other people think about that.

GP: Yeah, that's an interesting point. When I was talking to Dr. Janet Lowry Nason, the Asia Director for ACSI, she specifically pointed out that this was the first year that it had been quantified that there are more Christian school students in other parts of the world than America. And that's never been the case. So, it's always been that students in America were always as a body bigger than any other collective that you could put together in the world of Christian school student populations.

JD: Mm. But there are so many more students in other parts of the world, and if you get some Christian schools going in those countries that you know it's just phenomenal.

GP: Yeah, so it shows you maybe they're growing in number and then also yeah, she mentioned the same countries you did plus South Korea, and I think the largest Christian school in the world right now is in South Korea.

JD: Oh, I can believe that. 
GP: So yeah. It's interesting just to get a little bit of a history from you there. Okay, well we've talked about quite a few things. Are there any maybe transforming points, things that you feel like just really stand out to you in terms of Christian education in this modern era that I've not asked that you, you know, just feel that you could share with me now or uh, books that you've read that you could point to that really stand out as a great opportunity to learn more about what could be and might be in Christian schooling?

JD: Hmm. Well the one I just mentioned to you, I think is an important book. I don't think it's all that, that new, the "Teaching Redemptively". That's been a great book and, you know, I think getting our, our faculty to think in terms of what, what their purpose is, you know, the rest are maybe not quite in the modern era that I can, you know, think back to but you know, it is interesting, it is evolving even though as I said, it's a framework for what we do and should not change in Christian school. I think it's so important that we respond to what the world needs now and also look forward to thinking what the world's gonna need in the future. For too long, and maybe it's why some of the Christian schools have died out is that they were stuck in the old model and so you can't deliver an adequate education if you aren't changing with the changing world. I think there's a lot of literature out there now about 21st century learners and you know, what our kids need in the future even looking at core curriculum and things like that and I think we've got to be able to do that as Christians. I get real tired of the Christian community being behind the secular world in the school for education and responding instead of leading the way. And, you know, at one time I think we led the way but it doesn't seem that we're doing that any longer so we've got to be thinking pro-actively and figuring it out how, how we're gonna get that. I think the thing that really challenges us is the technology piece because it's very expensive and we've got to think about that, how we can do that. We've got these huge schools, school districts, public school districts, who are getting fabulous grants from you know your big computer companies and we don't seem to qualify for a whole lot of that money because of our restrictive policies and so, we have to figure that out, how God can bless us in that way because, you know, it really is an important key to the future. So those are our challenges and that's the types of things that $i$ think about.

GP: Good, very good. So, it's interesting to hear everybody talk about technology and how they see it used. You know there have been a variety of perspectives that I've interviewed so far.

JD: Well, I think the people who say that we're not gonna use it, and I know there's some schools that do that, there's some classical schools that are doing that, I think that is so foolish. They're burying their heads in the sand.

GP: Hmm.

JD: And I just, well, I'm so adamant that you've got to learn how to use those tools for good, and you just have to be wise about it.

GP: Mm hmm. Yeah and I would say that I'm very much agreed with you that, you know, the information's coming a mile a minute at all of us, and there's no way that we can continue to, students could continue to be taught even like I was. I graduated in 1993 from high school and um, you know I 
don't think there's any way that a student could be taught the same way I was and be able to really adapt and generate, you know, I don't know, coherent thoughts bringing together all this information if they weren't taught differently.

JD: Yeah.

GP: Somewhat differently than I, you know, because we could contain it all in a text book and um, you know, we really didn't have the internet to hit if we had further questions...

JD: Yeah.

GP: ...we had to come to the teacher. So, yeah interesting perspectives, that's for sure. Okay, well I'm gonna go ahead and turn off the tape recorder, I appreciate your time and giving me your answers to those. I know some of them were tough questions, kind of put you on the spot, I apologize for that, but you gave great answers so I really thank you for that. 
Title: Phone interview with Dr. Mark Eckel

Date/Time Recorded: 4/6/2011 10:35:05 AM

Record time: 0:49:00

GP: Okay so I'm here today with Doctor Mark Eckel, and he is with Crossroads Bible College. Dr. Eckle, can you tell me a little bit about just your title and what it is that you do and are interested in there at Crossroads?

ME: Sure, my title is Dean of Undergraduate Studies which means that I oversee the traditional side of what we do, we also have online and accelerated studies. My focus is on faculty as well as curriculum visionary producing and prompting new programs for the future as well as teaching myself. I teach Old Testament here as well.

GP: Great, thank you. What I'm interested in today is one: getting to know you and two: taking a look at gaining your thoughts on the development of improved learning environments for the 21st century Christian school.

ME: Mm hmm.

GP: ... and maybe how you've developed or hope to develop your goals in Christian schooling. I'm also interested in hearing about the core values and beliefs that embody your particular work as a Christian educator, administrator and the focus, just so you know, of my project really is to develop a coherent set of qualitative insights that point to trends in modern Christian schooling especially those that have sensitivity to methods that are making, or have a perceived ability to make great influence on students in the 21st century.

ME: Okay.

GP: So with that said, I'm gonna launch into question one: What are the key elements that you believe should set Christian schooling apart from secular schooling here in the 21st century?

ME: Well first of all, I would say that this is in essence the idea behind the word "holy" in scripture in the Old Testament. The word is "cavode" which means heaviness and it was actually the word that was used to evaluate who was rich and who wasn't. And so, the idea of somebody who was "cavode" was heavy or weighty or someone who was set apart by how much they had or who they were by how much they had. And when we think about holiness we often think wrongly about it I think, we have this tendency to suggest that to be some kind of mortal purity which it's not intended to be in the first testament. The idea behind holiness is to distinctiveness and to be set apart and frankly, you know since this is an interview and you've asked me to be honest and truthful and direct and forthright...

GP: Mm hmm. 
ME: ...let me be just that. Probably the biggest problem that we face in Christian school education today is that we are not distinctive. We are trying to beat the public school at their own game, we try to suggest that our test scores are better than their test scores and by so doing; we have a quantitative analysis then that suggests somehow that we are better. We talk about values which is a very weak word. We should instead, I think, talk about virtues: that is the interiority of the person, the true character, the spirit of the individual driven by the Holy Spirit who lives within us. We have a tendency to think that somehow we need to do education, like education is being done, instead of establishing an educational premise and philosophy based upon theological, Biblical truths that should drive then every single course that we do. So, if I saw going to, you know that's a very long answer to your very short question, but my suggestion in summary to the question is, I honestly don't think that we are and I don't think that we ever will be distinctive from pagan schooling until, and unless, we are actually going back to a true faith learning paradigm where we think the foundation of all subjects from a Christian point of view, a Biblical point of view and we see the permeation of that from every single thing that we do.

GP: That's great. Can I ask you a question building off what you said there?

ME: Sure.

GP: You mentioned going back and for me, it's uh, challenging thought to go back but I wonder if you would promote any idea of transformation rather than reformation, does that make sense?

ME: Could you expand on that a bit?

GP: Yeah, I wonder if, if you think that in operating in the way that you're talking about, creating a vision that's distinct and separate if maybe the call is more to transform and move forward, you know, in this whole Christian schooling movement or is there a time where you could put your finger on it and say, "we need to look at this part of history and kind of take a lesson from it?"

ME: Let me see if I can summarize this and by maybe tell a story to summarize it.

GP: That'd be great.

ME: In the early 18th century, the Irish were taken over by the English and because the English wanted to eliminate and eradicate Irish culture, history, language, uh, they eliminated Irish educators because they didn't want them to be inculcating the Irish youth with their background, with their cultural distinctiveness. And so what the Irish did was to actually create something called hedge masters, and the hedge masters were people that literally lived in hedgerows and caves and back water places where English army was not going and people in surrounding villages and towns knew about this and took their children to the hedge masters to be taught in faraway, un-toured kinds of places. I mention this because we have this tendency to think in Christian school education that we need all of these things because our culture says that we need all of these things. When we talk about true transformation versus let's say for instance the word you used earlier as reformation, when we talk about true transformation we have to think in terms of the essence, the core of who we are. And if the essence and core of who we 
are is so thoroughly distinctive as I suggested in my last answer, that things should be totally different then perhaps they should be and I would offer as an example of this the modern, in the last quarter century, the modern ACCS movement. The Christian School Association that goes back to a classical emphasis. And what Doug Wilson and others like him have done is basically say, "Look, we don't really care what the pagan public schools do and what they teach and so on and frankly we see a brain drain going on in evangelical Christian schools and so what we see as a very important issue is actually practicing the Trivium Method. And of course that's what been adopted and adapted so many different places and ways. This, I think, to me, is truly distinctive. It goes back to the essence of and the core of who we ought to be and what our major concerns ought to be in education and whether you agree with the classical movement or not, that really doesn't matter. What does matter, in answer to the question, is that they truly did transform education. They went at education in a totally different way that our present culture in the end of the 20th and beginning of the 21st century has done and that is to simply adapt and adopt what our culture has done. So I would offer that as an example, not necessarily because I whole-heartedly agree with that perspective or point of view but to suggest that this is truly transformative education and here's a good example of it because they saw the, the undervalue in Christian schools and they saw, well the abdication of a Biblical mindset in pagan environments. So that was what they were left with to create their own.

GP: Very good. Thank you. Great story. Do you see specific needs of students in this generation, maybe students you work with, that stand out as unique or different from past generations?

ME: [Deep breath] People like to make a lot out of things such as cultural or ethnic or national or linguistic or add a word to the phrase here, difference that we seem to have. There is a great deal of emphasis on psychological differences and learning differences and all of these kinds of things. What I emphasize to my students consistently and what I try to engage people in conversation in, with my colleagues, is this: that when we talk about these kinds of ideas, what we're really talking about are human issues. We're not talking about cultural issues, languages issues, ethnic issues; we're talking about human problems. So I think that when, when we begin to address issues that we see in front of us as human problems, as personal problems, rather then you know here's another area of life that we must now address because it has become an issue in our culture, I think we have lost once again the game. We've given away the game. See, we already have the game. The game is that we have been created in the image of God and we have from Genesis chapter one, essentially the engine that should drive every single conversation when it comes to learning or every single conversation as it comes to interacting with individuals. And then of course we also have the engine, the dual engine of Genesis three, which is that we are inherently corrupt human beings.

GP: Mm hmm.

ME: And the problems that we face generally, and our students face, generally are a combination interwoven of the dignity and depravity of human beings. So when we approach the issues that we face, the problems that we face as educators and so on, I'm not so sure that we ever begin by talking about it this 
way. We begin by saying, "Well, you know, we have to have a purity retreat because our students are having sex outside of school."

GP: [Chuckles]

ME: Or we, we have to address the issue of drugs and have a meeting about drugs. Or we have to have an anti-smoking problem. Or, or, or... And in essence we become Gnostics. We have subscribed to the basic philosophy that what really matters here is that we distinguish between our spirit and our person and our body and we are now going to focus on the external means by which we are going to transform our students. And instead of actually addressing them as human beings as persons, we begin to address issues or problems and in so doing then we have abdicated our Biblical responsibility of addressing problems and issues and situations and persons, as persons, and as a Christian person. And more than that, a Biblical framework of why understanding why we do what we do and who we are. I'll give you just one example; I've given you many examples so far but, just one more example as it relates to faculty and administration. One of the phrases that I absolutely abhor is the phrase, "Human Resources" or the "HR Department".

GP: Hmm.

ME: I abhor it because I'm not a resource to be used and then tossed when I'm no longer needed. I'm a person, a human being, and even in the ways in which the nomenclatures that we use to frame our thinking about our departments or about the uh responsibilities that people have to certain things, we have a tendency to mock or modify what we see around us in the pagan culture and adapt, adopt it to our own purposes without thinking Biblically about it. So there's just one example, I've given many about students and how we tend to address those issues, or uh, those individuals but now just to suggest something about administrative processes in the Christian school. And I realize, as this is being recorded and I'm giving you these very long winded answers that this might be much more than you wanted but I think it's important to continue to say, to go back, to say, we need to have a Biblical framework and if we don't have that then the very first question you asked me has absolutely no bearing on anything and that is, how are we going to be distinctive?

GP: Mm hmm. Very good. Thank you. Are there any technological needs that you see as essential to be taught to our students here in the 21st century? There are many things I know that we're teaching but what do you see as most essential for them as students and moving into life?

ME: As by technology you mean...?

GP: Really the broad sweep. Everything from computers to programs to, you know newer devices that are available. Obviously even cell phones, for instance, are becoming multi-faceted...

ME: Mm hmm. 
GP: ...you know in their, in their capabilities. Are there any, you know is it a, is it a program approach? It is an approach to maybe being able to use them or capable to use these technologies in a way that's most beneficial? So, how do you see that playing out for us as teachers?

ME: Sure. Well, I'm gonna start sounding like a broken record here really quickly...

GP: That's okay.

ME: ...in answers to all of your really good questions. I am I am of the belief that my computer, like my cell phone is simply a tool. I don't believe that I need a computer class nor do I believe that my students need computer classes outside of perhaps, if they've never engaged a computer or anything like that that's now necessary for us to use as tools just as much as paper and pencil has been used in the 20th century for instance. I'm not so sure that teaching a class on what Jacques O'Lool called technique in the French way of speaking; I don't think that that's necessary. I think that what we have allowed to happen in so called technological arenas is that we have allowed technology to drive education instead of allowing education to use technology as a simple tool and we say, "yes you need to double space this and have one inch margins all the way around and print it out and give it to me and yes you can type this on your computer and word process it and so on." But what we have ended up doing is we have said, "Well because technology is so impressive and overpowering and...And...And...We have essentially bowed to the totem of the idol of technology saying that this is the end all and be all of all things. Now, that's going to sound very ludite-ish as people might hear this but that's not my point. My point is that we have once again put the cart before horse, and frankly, we don't even have a horse anymore. We simply have a cart sitting in the middle of this place going, "well, you know we have all these wonderful technological tools but we have no ethos, we have no..."

GP: Hmm.

ME: "...no essence of, from where we think about these things. And from a Christian point of view we have not thought thoroughly about how, how do we frame a technological discussion? How, do we, let's, let's just say, give an example of this: Do we hire a person who is technologically adroit for instance because they're technologically adroit, or do we hire a person because they are a Biblical thinker and they're going to be teaching Biblically and they're going to be thinking Biblically and they're going to help my students to do this. And then, because they are in this arena, because they are experts in this arena then they will also coach them and guide them and direct them in these other areas. And I would say the same thing by the way for math, science, history, literature, and football.

GP: Hmm.

ME: Nothing is different in any of these discussions. The ultimate issue comes back to: Do we want to be Biblical about these issues and give Biblical answers to these kinds of questions or are we going to allow the culture to dictate to us, as Christian schools, what's most important and what our students should know or learn? So, going all the way back, after listening to my preachment here, going all the way back to the original question, which you asked: Do I think that there are certain things that students need to 
learn? Frankly, I think they already know them for the most part now I operate in a school where I, I have very poor students in the sense of economic poverty. So that they need other helps and other directions, but frankly even in this case, they know so much more about things technologically than I do. What they don't have and what our Christian schools don't have, I would argue, is that they do not have at their bottom line are Biblical thinkers in all of their areas of study: history, science, social studies, whatever else, as I've just indicated. We don't hire people for those things. We hire them for their expertise first or their technique first and then we think, well, they their devotions and go to church and so they must be a Christian school teacher.

GP: Very good. Do you think there are any key issues that are dividing students and their teachers in the present age? Things that just come up in your observation as a teacher or as you look at other people's classes?

ME: I taught in Christian high schools, junior high schools for 16 years and then I went to Moody Bible Institute to teach for 6 years and was in their Admin Program there and then I came back to Indiana to actually begin to teach in Christian schools again because I'm such a practitioner and I, I love education. I love students and I love the classroom. And what I discovered was that when I came back into the high school classroom after being gone for six years that the thing that most stood out to me was the issue of respect and in all of my years of instruction I always gave out you know a class rules, kind of a class philosophy, class doctrine kind of page that both students and parents had to sign and then return to me. And the essence of it was you know, this is who I am, this is how I teach, and this is how we're going to go about looking at scripture, and so on. But what I discovered was that I had to identify respect as a new issue that I had never had to identify in the past even after only being gone for six years. And so, that came up immediately and forcefully in the first few months of my teaching with high school students again that they did not understand what it meant to give respect. So let me again, as I've done with all of these other answers, give you the Biblical base, the Biblical base is that you don't, I don't earn your respect, you give respect and the reason is because according to places like 1 Thessalonians 5:11 and 12 and Hebrews 13:17, God has placed authorities in our lives that we automatically acknowledge as people to who we must give their due and that is respect. And so I don't earn anything from you, you simply give it to me because I am in this position of authority that God has foreordained that I should be here for. What we, I think, generally as a culture have seen is this lack of respect generally in culture which has been perceptive over many years, decades I suspect which is nothing unusual in human history by the way. Ever since Genesis 4 with Cain and Abel but what I'm suggesting here is that if you're going to ask me now what have I seen? That's probably the bigger issue that I've had to address in these years coming back.

GP: Very good. Yup. I understand. Positional authority seems to have struggled even in the Christian school as a matter of respect. You've made many suggestions about how you see Christian schooling developing into a transformative philosophy and vision, what are two or three key steps that you believe must be taken immediately to bring about the kind of transformation and environment which you've mentioned so far? 
ME: The very first thing, the biggest problem that we face in Christian schools, I'm, I'm gonna give you a three-fold issue here, I think the biggest problem we face in Christian schools first of all is our boards, the boards of the Christian schools. The boards of our Christian schools tend to be run by businessmen, by business principals instead of an understanding of what it means truly to think biblically and then to teach biblically and then to run school biblically. I'm not averse to having business people on Christian school boards but what I'm saying is that when business practices consume the biblical educational process and the philosophical premises then we have really found ourselves in really deep water. I actually wrote an article about this when I was back teaching in Moody in '02, it was published in Christian Scholars review, I think I just put it up on my website, it's called "Selling the School" the essence of all of my concerns are laid out there so that you can go back and see some of those things. But I would say that that's pretty much where I began. Let me just give you a brief story about this. When I was teaching in Michigan, I'Il never forget this as long as I live, I was in this huge meeting, it was all teachers, all parents, all staff, everybody was there and the board was there and the board chairman got up and he said, he looked at, at the teachers and he said, "This Christian school is a ministry and this is the reason why we cannot give you a salary increase this year." And then he turned in the very next sentence, I kid you not, turned to the parents and says, "But we run this place as a business and therefore we are going to be raising tuition." You know you might as well have just taken me up front, slapped me across the face, kicked me, you know, beat me because that's in essence what had happened. The board had basically said, "You know this is how much you're worth, which isn't very much, and oh, by the way we really think this is a business but we think that you ought to be our slave teachers over here and work for a pittance."

GP: [Chuckles softly]

ME: That's in essence what happens on boards when there is no empathy and by empathy I think it's thoroughly important that you have Christian school educators on boards, not necessarily that they are teaching at the school where the board is giving oversight but you have to have people who have been there and done that instead of folks that are turning out widgets and turning off their production lines, assembly lines at the end of the day. That's not how education happens. The second issue that needs to happen immediately in Christian schools if there's going to be any transformation is that we have to have administration who understands what their key role is. And the key role of all administrators is to be a shepherd. To be a shepherd means that you do two things that you provide for your sheep and that you protect your sheep so that there is nothing that you wouldn't do for your teachers and that there is nothing that you wouldn't give if it's within your scope and framework of giving that to them. The issue of shepherding them also includes, within that framework, this faith learning integration thing and what, what we end up having with many administrators in Christian schools is a non-understanding of what it means to think Christianly and then apply that in an educational framework so that they do not lead their people, they do not provide and protect them within the framework of faith learning integration. This actually was what my dissertation showed and it was one of those wow moments you always hope for when you're, you know, writing a dissertation and it actually happened in mine where when I asked the question: Did going to a Christian university or a pagan university matter in terms of how you teach 
in the Christian school classroom now? That had very little difference, what had larger difference was whether or not my administrator practiced this and saw it as important and taught it and emphasized it and coached it and prompted it every single day. Those teachers who have sought every single day in their administrators uh, uh, this was on the frontal lobe of their mind that, you know that actually, the transformative emphasis of Christian schooling actually was taking place there. The third area that needs immediate help and this goes back again to my dissertation about, but I'll broaden it for this discussion, is, we desperately need Christian higher education to have, within their framework or scope, if you, in their Ed departments, if you wanna have a public school track, great but you need to have a Christian school track so that you say to your Christian school teachers, "Look if you want to proceed down this line of thinking and reasoning and so on, you need to think Christianly about this. You're not gonna be able to practice these things in a public school." And so what we end up doing, and and many different Ed programs in the country in fine Christian schools, is that we say, "you know what, we're gonna train you for public, we're gonna have a certification process where we're really concerned about accreditation. Oh by the way yeah this, you'll know in Christian schools too." And what we don't end up doing is we don't end up teaching math, science, history, language arts, fine arts, everything from a Christian point of view. We end up going to the all of the latest research which now runs all education research, that's a whole separate discussion, but we, we have, we allow research now to become the driving force in our thought processes about education. What's the newest? What's the best, best practices? All of those kind of things instead of going back to invest ourselves in a scriptural study of what does it mean to think and to teach as a Christian? And until and unless Christian universities do this then they will continue to turn out people who are fine wonderful Christian people who may have a tremendous impact relationally in the public school system but have been poorly if at all trained to think and teach as Christians in a Christian school.

GP: Excellent. Thank you. As you're involved in hiring processes, let's say you were involved in a hiring process for a Christian secondary school what qualities or characteristics would you look for in applicants to provide students with the kind of education you've been talking about?

ME: [Laughs] well, um, let me; let me read some of those to you because I actually wrote something entitled, "Finding Faculty". Let me just read you what I've written in the past about this. And I'll just out, [phone rings making voice hard to hear] send this to you if you're so inclined, but l'll just read it for the sake of the interview, I'll just read it off right now.

GP: Okay.

ME: But I'll be happy to send it to you. These would be three interview essays, notice what I said, essays. Describe your personal understanding of faith and learning. Write out a paragraph example of how you might practice faith learning integration in a specific lesson plan for your discipline or grade level. In 50 words or less, explain the distinctiveness of Christian education. Read the school mission statement; explain how you would practice discipleship in your area of responsibility for your grade level. We work with various levels of student ability on campus, how does a Christian world view affect our involvement with "learning differences" in any category? We function out of partnership with parents, give specific 
examples answering how and when you would communicate with parents include in your answer an interaction over discipline. Explain a biblical view of discipline. Explain a biblical view of grading and assessment. Write a written reflection addressing your possible contribution to the school's identity and mission. And then during the interview process, I would ask questions like: Respond to the following statement, a biblical view of education could be explained as content centered, teacher directed, and student discovered. Or how is the statement: Jesus is Lord of all things, practically applied in your classroom? Or how do you show passion for your subject and compassion for your students? Or if the school mission includes the task of so called academic excellence, how will you master your content area to the glory of God? I could go on and on here but there are three pages of these things... [Laughs]

GP: [Laughs]

ME: ...I don't know if you wanna tape up your tape recording with all of this.

GP: No, that's great. That is great. Is that on your blog?

ME: Uh, no it's actually not. This is something that I wrote boy I don't know five, six years ago I think but I'd be happy to send it to you.

GP: That'd be great, yeah. That's excellent. If you could, tell me about a time or maybe a collection of times that you felt most positive about your work with your goals and philosophy, I said values but I'll go to your word of virtues in Christian education when they were just being met, you felt like you were hitting a homerun so to speak?

ME: Sure. It kind of, we're dealing with human beings again. Most of what we know about humans from a biblical vantage point much less a creation vantage point, that is, by that I mean common grace, just look around us kind of thing. This is the way our world operates and works because God made it this way. Probably the thing that first comes to my mind when you say that is that this isn't, this isn't something that I always automatically see in class. In fact, very infrequently does this happen so, from time to time it does, but I'd rather address your good question from the backside and that is, I honestly think that you need to stay in education, in Christian school education for five, ten, twenty, twenty-five years so that you can have students come back to you on Facebook, text message, drop by, cell phone call, send you a note, whatever it is to say things like, "You know, you ruined watching movies for me, forever."

GP: Hmm.

ME: And by that, they meant things like, I taught them how to actually watch film, how to practice a critical understanding of film watching, and so on and so forth. Those kinds of responses from students are the things that are most gratifying, I think, in a Christian educators' framework to have students come back to you years after they have been in your classes and say that, "I still use, every single day, what you taught me." And it's not as if they remember every single answer to every single quiz or they could pass any test you gave them in the past, that's not the issue. The issue is is always one of what are 
the salient concerns that you constantly had for them? And what did you constantly bring to the table that was, that were repeated over and over again as God does in his word so that it made such a marked impression on them that they left knowing that this was, these were the most important issues in all of life. So, I would say, in answer to your question that the home run is not had until after you've so called retired from the game that is until your students are gone. I honestly don't think that, that is, as I said there are exceptions to this but normally speaking we do not see the benefits of what we do in the interiority of the person until years later.

GP: Very good. Actually just to let you know many of the people I've interviewed had very similar notion on that so I'm seeing a common thread there in your answers.

ME: Good.

GP: Coming back, staying with it, you know, sticking the course.

ME: Yeah, you have to because that's, you know, that's the whole essence of education, you know, at its core is relationship and the essence of relationship is time. See you have to spend time with people and the best time, and this is the reason why I'm not a pastor, no, no side swipe at pastors here but uh, the reason why I think the Christian educator has so much more impact is because 45 minutes every day, five days a week, 180 days out of the year I go to all your games, I listen to you sing in the choir, you know on and on we go, and it's time that I spent with you.

GP: Very good. Are there specific events, people or situations that have shaped the way that you view Frances Schaeffer education especially Christian education and uh, in term then relate that to people like me, or students or parents?

ME: Sure, sure. Well, as I've suggested all along, this goes with a story, alright?

GP: Mm hmm.

ME: When I was 16 , I didn't go to Christian schools, I went to public schools. When I was 16 I was the kind of guy who was always preaching, you know, I played football, I played lacrosse. I was somebody, you know, even in a school of 200 students that was involved in things that $i$ loved to do in athletics and so on but I was always preaching too because I was a Christian and was, that was just who i was and people knew who I was. One day when I was 16 , the guy sitting next to, behind me was actually an allstate, star all-state player in soccer and a friend of mine. He leaned during morning announcements at eight o'clock in the morning and whispered in my ear, "How, how can you believe in something you cannot see?" Now he was an atheist and that's the reason, and he and I had had discussion and so on but I was being asked questions when I was in high school that I couldn't answer. And my church, even though it was doctrinally sound, it was culturally blind and deaf I think to how to address people that were different from us who sat a pew every Sunday. And so, I was introduced to a man by the name of Frances Schaeffer...

GP: Hmm. 
ME: ....and starting with "The God Who Was There" and then his next book "He is There and He is Not Silent" and then "Escape from Reason" and on and on until I had read all of his books by the time I was out of high school. Frances Schaeffer's seminal thinking planted seeds in my mind that have continued to this day actually to make me think differently about being an educator so much so that now I'm, I'm on the cusp of developing a brand new program for our college which is called Inter-Disciplinary Studies which is actually a program that will at the end allow students to create their own program toward their gifting as the Spirit has gifted them in their person but that's a long discussion as well. But nonetheless, interdisciplinary you get the sense of this there is no dichotomy between secular and sacred obviously and so this was Shaffer's big push and he probably more than anybody else though I never want to L' Abrie and I never met him, I read all of his books and they continue to have an impact and an imprint on how I think about life which of course intersects with who I am, the essence of who I am in my gifting as a teacher and so that kind of belief system or that kind of philosophical theological thread could be just as important to an architect or a business person or a computer person or a drama person or an economist or I could continue down the alphabet...

GP: Mm hmm.

ME: ...pick, you know, vocations. The ultimate issue is that, are we thinking as Christians about whatever it is that God has gifted to do in the place that he's given us to do it in? So, I would say Frances Shaffer more than any other person was the person that influenced my life as an educator.

GP: Great, thank you. Are there a couple, maybe ways, methods that you believe could be brought to the minds and methods of our teachers in Christian schools today to make happen what you've been talking about? You really centered in on some key items that you mentioned over and over again, which is excellent, but are there some ways that, maybe I, as an administrator could bring that forward to, to my faculty?

ME: Yeah, absolutely, you should hang up the phone as soon as we're done talking and...

GP: [Chuckles]

ME: ...you should go and hire yourself somebody who is going to oversee and give direction to your teachers in faith-learning integration. I've made this suggestion to folks, I actually was doing the enabler series through ACSI back in, I think I did '01, '02 and then '03, '04 again biblical integration they called it then, I emphasize it now as faith-learning integration. But the, what I've suggested to schools is that you know you have a director or somebody let's say for instance an athletic director, you have a curriculum director, you have all kinds of different kinds of people in your offices, in your place of busi- in your place of education, what, what we don't have is a director of faith-learning integration.

GP: Hmm.

ME: And so, my suggestion to schools considering the economic concerns that everyone would face is that, let's say three or four schools get together and pull their resources and each one contributes $25 \%$ 
to this guy's salary and benefits and that he travels around, that, you know, day to day, week to week to these schools and literally sits in classes with teachers, helps them to frame their processing of how they think and teach as Christians. And that would then, would, I think be probably the best method, so called method, to immediately impact the Christian school. It was the reason why I actually came back to where I came to Indianapolis because at Moody our curriculum had changed and it wasn't that it was a bad thing or a bad thing to place or the things I was teaching were bad or wrong, it just was, I'm just such a practitioner that I was given an opportunity to be director of faith-learning integration in a Christian school and um, that all blew up in my face, that's another huge long story that perhaps we'll have to talk about at some juncture in the future but nonetheless, I still believe that walking with teachers day to day and by the way having this person teach classes is hugely important that is that the teachers respect the individual because they are in the classroom just as they are. I think that all of this is really important. So I would say that that would be a predominant idea for me that is that folks see an immediate person in their midst that's helping them with the educational process of thinking and teaching as a Christian.

GP: That's a great idea. Thanks for sharing that. Is there a specific role you see parents needing to play in the modern Christian school?

ME: [Long pause followed by sharp exhaling laugh] Oh boy. [Chuckles] I, I'm at a, I'm at one of those situations of, can I pass onto the next question? [Chuckles]

GP: [Laughs] I sensed that. Yeah, we can, if you want, sure.

ME: Yeah, let's go onto the next question. Is there, is there any other thought on this need to transform education in the 21st century Christian school that maybe I've not asked you about; you just feel passionate about and want to share with me? Or any kind of reading that you'd direct me to?

GP: Oh boy. Just kind of an opportunity to share a bit more wisdom if you would.

ME: I'll send you my reference list from my dissertation and you can have all the reading you'll ever want.

GP: [Laughs]

ME: [Chuckles] I think my reference list was 40 pages.

GP: Oh my word.

ME: It was quite something. So there you go in terms of reading, you know, I'll send that to you if you're interested.

GE: Sure.

ME: Let me go back to address the question that I wanted to pass on a moment ago and... 
GP: Sure.

ME: ....is there anything else? I think this is what I'm going to say about that kind of wrapping this up in that, so...

GP: Mm hmm.

ME: The problem that we face in Christian school education is in essence a problem of The Church, capital "T" and capital "C"...

GP: Mm hmm.

ME: ...The Church is pathetically weak and it's pathetically weak because it doesn't teach Christian doctrine, dogma, teaching, instruction, it doesn't teach. It doesn't teach people the essence of what it means to be a Christian and then to add insult to injury, not only does it not teach these things but then it does not produce discipleship processes whereby we train men and I'm, I'm emphasizing men now, leaders in the home, fathers so that pastors are not concerned or at least not spending time with the very people that are supposed to be leaders in the home. I mean, in the first testament men, the fathers, were to be literally priests, that's what the book of Exodus calls them. The fathers were to be priests in the home and so they then bore the responsibility of teaching and training their own family.

GP: Mm hmm.

ME: I think that the problems that we see with parents, with educational processes and philosophy, all of the issues I've suggested about Christian higher education and boards and administrators and faculty and students and everything else ultimately comes back to The Church. This is in Eccles- this is a question of Ecclesiality, the study of The Church and that is what, what are we to be? And the answer to that question is, going all the way back to my very first answer, we are supposed to be distinctive and we are not. We are not different, we do not seem different to people generally in the culture. Now we're different of course when some, I'll try to keep my words kind here...

GP: Mm hmm.

ME: ...some pastor in Florida burns a Quran, I mean we're all over the news now but that's not teaching Christian doctrine. That's not Titus 1:9 "Encourage each other with sound doctrine and rebuke those that oppose it." That's not that. That's something else altogether. And so when we think about being distinctive and about being different we have to go back to places like Leviticus 18:1-5 where God says, "You know, I took you out of Egypt and it was really bad there and there was all polytheism and the culture was, you know, seeded with constant attacks on your distinctiveness as my people but I'm gonna take you to even a worse place which is Canaan and you're gonna be smack dab in the middle of all of these folks and you're going to have to learn how to be distinctive." I think that's the essence of, of what it means to be a believer in Jesus Christ that is that we are totally different from the culture around us. Now that's not to suggest by any means that I'm not a sinner and that I don't struggle with my own temptations and my own fallacies and my own problems, you know that's not, that's not what we're 
talking about. What we're talking about is do we group ourselves in a community of like-minded individuals who stand under the authority of the Scriptures and then live our lives in such a way in community so that we encourage each other in sound doctrine and then stand together to rebuke those that oppose it. If The Church does that then the Christian school will do exactly that but until and unless The Church does that, then the Christian school will always be anemic and weak unless by itself it can create its own community and some have done this by the way...

GP: Mm hmm.

ME: ...can create its own community that is not prompted by parental control by the checkbook as it were, you know when the parents say, "Well, I'm gonna pull my student if you don't do this for me." You know that kind of stuff. If we're too consumed by the parental control of that then we never will be distinctive because parents are controlled by the cultural morays of the change of wind that they feel blown about by every day. So, it comes back to distinctiveness I think, and it begins with The Church and it begins with pastors and it begins with teaching and discipleship of men.

GP: Hmm. Excellent. Well thanks for sharing that and I know we've taken quite a bit of your going through this but I really appreciate everything you've answered and the way you've answered so thoroughly. And yeah just it's been really a pleasure to talk to you. I'm glad that Tim directed me toward you and just very interested even in your blog and already having read it quite a bit of your article writing on there so. Yeah, um, I don't know if I told you but I'm originally from Indiana, I actually graduated from Ball State University.

ME: Oh good.

GP: Yeah, my wife and I both and uh, that's actually where we became Christians through Campus Crusade.

ME: Great. Excellent. 
Title: Phone interview with Dr. John Foreman

Date/Time Recorded: 4/5/2011 9:10:35 AM

Record time: 0:56:36

GP: Okay, so I'm talking with Dr. John Foreman today. He is the Superintendent at Worthington Christian, I believe that's the correct title, is that right, John?

JF: Yes, Worthington Christian School System is the school's title.

GP: Okay, Worthington Christian School System and uh, Dr. Foreman to let you know what I'm going to want to ask you questions about today regard just your thoughts on the development of improved learning environments for the 21st century Christian school. And, also how you have or hope to develop your goals in Christian schooling. I'm also interested in hearing about the core values and beliefs that embody your work as a Christian educator and administrator. The focus of my project through Cedarville's Master's Thesis is to develop a coherent set of qualitative insight that point to trends in Christian schools that have sensitivity to the methods and mediums that are making or have perceived to have the ability to make the greatest influence on students in this 21st century of course within Christian schools. So, uh, I've got a set of questions, I'll try to keep us on point as we go through them but if we wander a little bit that's okay if there are things that come up that you may want to take into more depth or just share your wisdom on that would be great as well.

JF: Yeah, I'll do my best.

GP: If you don't mind, I'll launch into the first question. What are the key elements that you believe should set Christian schooling apart from secular schooling especially in the 21st century?

JF: Well, I think the first and obvious answer would continue to be our philosophy and our world view. I think the Christian school people would be quick to say that that's just one great non-negotiable in Christian schooling is our Christian school philosophy of education, the way we approach the subjects as far as Biblical integration, a lot of those terms that are very well traveled terms but none the less they are very, very true today. Some schools, I think, have done a better job and others hanging onto that over the years. We certainly are pressured every year towards compromise and some have done that. I think some have done a very good job of staying true to their mission. I would say that would be the first thing that would come to my mind. Give me that question again, Gabe.

GP: Sure, uh, what are the key elements you believe should set a Christian school apart from secular school in the 21st century?

JF: Sorry for the noise there [ringing continues]. Really, this is my twentieth year in school administration, Christian school administration, and I've come down to, in fact I'm looking at it right here. I have a list of six things that I've come up with that I call the "Critical Components of Successful 
Christian Schools" in my experience with ACSI and with three different Christian schools now, and I've been on over 20 accreditation teams now for ACSI. I've chaired about 17 of those, you start to see patterns and trends, and so I've come up with this list of six, and I teach this to my school here and I don't know if I've made my other administrators memorize them, but we all have these up on our office walls 'cause I believe in them so much that the first one is, is "Quality teaching by quality teachers on a daily basis." And I believe in that so much that personnel is so key to what we do, I think of all the decisions we make as an administrator, fewer is important as personnel. I like what George Barna says, he says that, "In personnel there's three key factors: the person has to be called of God, they have to have that ministry calling, can they articulate that in an interview? Are you sensing a movement of the Spirit that God is preparing this person to serve him in Christian schooling? Number two is that they have to have Christ-like character that they are worth modeling so to speak. Your child, my child is on the team or in the classroom and as a parent, would I want my child to become more like this person? Because the Bible says when the students are being trained, they will be like their teacher, their coach, their yearbook advisory, whoever has that influence on them.

GP: Mm hmm.

JF: And number three they have to be functionally competent. And I like that, I think too many schools focus on the functionally competent and they get somebody who has really strong secular credentials, there's nothing wrong with those but then they're very weak spiritually and there no integration, there's no philosophy, there's no role modeling spiritually and then you've got parents paying for a private school education. Some school, you know, go in the other direction the people are wonderful strong, godly people who can't teach the way out of a wet paper bag, I don't think that should be the case either. My mentor and advisor in grad school, Roy Lowry, used to say that, "A student should never have to take an academic back seat to get a Christian school education." I believe that's true, so I think those would be a couple key things that I would: philosophy and all the aspects that go into philosophy and personnel. If I was gonna put a third one on that list, Gabe, I think it would just be, just being a school of integrity. In our finances, that we have integrity, we're fiscally responsible. If I have communication with parents, I tell the truth, I don't hide things from them, and I know they don't need to know everything in all the times but there should be a level of transparency there. I think parents get dissatisfied when there's not. In, in our parents, and our students look at me as a leader, look at our school and say, "You know what, I may not always like what he says but he's being honest. They're telling me the truth. I've never found any error in this communication that this is this is reliable information." Does the bank feel the same way when we go to borrow money? Does an accreditation team, North Central ACSI feel the same way, that here's a school that's honest? I think that institutional integrity is just, is critical and I that's what'll keep people with you even though the storms are tough sometimes and I think that's what'll make people go away from you sometimes if you hit some bumps in the road if you just don't have that credibility professionally but...

GP: Very good. What specific needs of students in this generation stand out to you as being unique or even different from past generations? 
JF: Yeah, ok. Well again anybody in education knows that the home of the family is not what it used to be and that has now, I think, impacted public schooling and now its impacting Christian schooling. The number of single parent families we're dealing with now, the number of dysfunctional homes. Like a lot of administrators, I deal with finance all the time, I deal with past due bills and things like that when they escalate to a certain level, it hits my desk. So many times even our Christian families just don't have control of their own finances. They live beyond their means. The economy gets tight like it has here in Ohio. Our school has many people who are employed to finance somehow, they're in construction, they're in real estate, they work with Chase bank which is a huge employer here in town or somehow its connected to the finance sales world and when sales slowdown and commissions drop off and financing isn't happening, it just trickles up and down and all over the place. So, I think those couple things would come to my mind first of all is just that the stability of the home, even the Christian home, is not what it used to be, although, certainly stronger than other homes. Church life for our young people isn't now what it was for me when I was a kid. It doesn't mean it's bad necessarily, it's just different. I was raised in a, you know, every time the doors were open we'd go to church type of home. Most of our young people aren't being raised that way today. I see kids getting up out of service at ten o'clock in the morning to go to soccer games and things like that, and I just, I haven't raised my own children that way but some do and I have to be realistic and say, "Okay these kids are in a Christian school to where the parents are going to put a higher value on weekend athletics that happen to be on Sunday morning then they will, their kids developing that habit of being in God's house every Sunday." So anyway, it's just, I guess those would be a couple things I would say just looking at the social and the spiritual. I think in the academic, I think that parents are much more savvy consumers of Christian schooling then they were twenty years ago when I first got involved with this, uh, twenty-five years ago now I guess. It was, when I first got involved, when I graduated from Cedarville in 1983 and uh, went out to the Christian School world started out in Pennsylvania the small school in Columbia County. What I saw there was parents, parents were looking for that safe haven, they were looking for that, their expectations academically were not as high, whether that was, needed to be there or not I don't know. I certainly think as a teacher I did my best when I was twenty-five and fresh out of school, twenty-four, whatever I was at that age. But I think, I just see today, so anyway looking back to that, Gabe, I would say that parents expectations academically were not what they are today. That, that sounds bad to say that but I think it was it was coming out of the decade of the 70s to where there was that huge explosion in Christian schools. And if you looked at an ACSI directory, you'll see many, many, many schools, like even the one that you're at that was started in the 1970s.

GP: Mm hmm.

JF: The school I'm at now, let's see at Valley Christian where I was at for ten years in New Mexico started in 1973, Worthington Christian started in 1974, very common that decade of the 70s, we started a lot of Christian schools around this country. And parents were looking for a different type of education, I think that as the decades have gone on that has matured to where parents are saying, "We still are looking for that Christian environment but we want AP classes, we want our kids to, if they're academically advanced we don't want them to feel like there, there's no advanced math classes for our kids or 
whatever." So, I think our parents are different consumers of Christian schooling now than what I first saw twenty-five years ago when I got involved in Christian schooling.

GP: Can you identify, John, two or three necessary changes that you believe teachers much make to reach students in the 21 st century?

JF: I think teachers, because of all the dynamics we've talked about with society and the home; I think teachers must continue to be that lighthouse spiritually. They have to be rock solid themselves because our kids just don't have that around them anymore. Hopefully at church, hopefully at home but other than that, it's just not in our society like it used to be, we, I'm older than you but uh, [chuckles] I assume but uh, you know you've heard stories of other people. I'm fifty three years old now, I stole a piece of candy from the candy store when I was a kid at a grocery store the grocer would catch me, call my dad, grocer would chew me out, dad would spank me and they, they both parented me so to speak. I never did that but had I done that that's the way it would have been handled. I got in trouble at school; I got in trouble at home. There was never any debate at my house whether or not the teacher at the school was right, they were right. If I got in trouble, I was in double trouble.

\section{GP: Mm hmm.}

JF: That's not there anymore today, now today what we see, with some parents in fact to many parents is that the kid gets in trouble at school, "I will call on the phone, I will email somebody and I will chew them out royal because my kid is right, your kid is wrong, the teacher is wrong, how dare you, you know this and that and everything else." And you've had to deal with that as an administrator.

GP: Mm hmm.

JF: So the school is constantly on the defense, we almost have to feel like we're miniature lawyers in some ways...

GP: Hmm.

JF: Okay, here's a kid that's gonna get an "F", do I have all my documentation put together for when the challenge comes and it will that I can demonstrate that I have done the right thing in failing the student? That wasn't the case, not too many years ago. So, I've often said, Gabe that uh, somebody has to be the parent, somebody has to be the adult in the family, some, and unfortunately sometimes, it's the child. And we have a generation of parents, not everybody but some, and you've seen some of this too, that I think they fear the wrath of their own children. "Heaven forbid my eleven year old daughter would be upset about something at school 'cause I better get upset too." For my parents that wasn't a real issue, if I was upset about something at school that was tough. What I needed to do was listen more to my teacher next time and not get into trouble. So that whole concept of, I will, as a parent will argue and debate with the school was just not, nothing I was raised with.

GP: Mm hmm. 
JF: So, it's, so I think teachers, going back just to the spiritual aspect of that, I tell our teachers, and as you know I was a missionary teacher for five years in missionary school administrator out on the Navajo reservation for five years and God just really honed into me at that time in my life that if we are not praying for these kids, because most of our kids there came from unsaved homes, again we were a mission school, its exactly what we wanted was to have as many unsaved kids as we could. We wanted to share Christ with them, that if I'm not praying for my student, who is? James says, "The fervent prayers of the righteous avails them much." So, what's the converse in that? Is there a downside to this child is not being prayed over? I think theologically there is so I always tell our teachers, I said, "Understand, you may be the only group of people who are regularly praying for this child if they come from an unsaved home." And we used to take that as a very serious responsibility, so I think to go back to my point, I think that the teacher needs to be a constant spiritual lighthouse, they need to be a stronghold. This is not uh, we are not a hospital for the spiritually sick, I think schools make a mistake when they try to redeem people through employment. So, for example here's somebody that is a teacher but they've got all sorts of issues going on and they're in and out of church and, "Boy if I can get them into a ministry, then they'll grow spiritually." Mission are, in my mind, are horrible about this and I'm still involved with a mission out west on the board and I've seen us make this personnel mistake over and over again to where we try to help somebody so we give them a job. And what we've done is taken somebody who is spiritually crippled and we have put them on the front lines of the battle and wondered why it doesn't work.

GP: Hmm.

JF: The church, there certainly is venues for those who are spiritually sick so to speak, the church and bible studies and everything else but we're not a hospital for the spiritually sick, we're the battle front of the spiritually strong and I would go back again to that point of the teacher, we must have teachers like that today that are just pure and confident and deep in the word and they just have that passion for Christ because our kids are not seeing that like they used to and sometimes even in their own homes, unfortunately.

GP: Hmm.

JF: I, I would say if there's one thing I would want a teacher to know about working with our kids here in Columbus of this generation, I think it would be that, "Be that rock. Be that vibrant believer. Be that story that the kids talk about twenty years from now." I always love to talk to perspective parents and I ask them, "Tell me about your favorite teacher. Why was that person your favorite teacher, your favorite coach?" It always comes back to relationship. "They saw something in me nobody else saw. I didn't think I could, I didn't think I could ever steal second base, I was too slow. This coach taught me how to do it. I couldn't believe I actually stole a base, you know." You hear those stories over and over and it's because some teacher, some coach, somebody somewhere, some pastor, whatever was a teacher and they took that child, they took that teenager and said, "You know what? I Know how to make you better and I'm gonna teach you how to do this. You can learn algebra cause I'm a teacher. I'm gonna show you Algebra. You work hard, hang in there with me, you will learn Algebra." And those 
people are just revered in the minds of the student forever and those become those favorite teacher stories.

GP: Hmm. Good stuff. What technological needs to see as essential to be taught and used in the 21st century Christian school?

JF: [clears throat] Uh, that's a good question; obviously variety is the spice of life when it comes to our, our teenagers. Again I'm 53 years old, I'm raising a 15 year old and a 12 year old and the world of technology for them moves a lot quicker than it does for me, although I feel pretty comfortable in the world of technology. But obviously I wasn't raised on it like they were. So, I think one of the things is just the variety, one of our, we have ten strategic goals for our school. We did a visionary process the last couple of years when I first came, felt the school is it's an excellent school. It's always been very strong athletically, academically, fine arts, it's a good school in many, many ways but what, when I get talking to people and I said, "What, what do you need a new leader to do?" They really said, "You know what, we need a new vision. We just need a fresh vision. We've been kind of one the same pattern for twenty some years," and it was a good pattern, nothing wrong with it, they were just ready for something different. So we did a visionary process, I tried to meet the people and parents and students and said, I said, "Just tell me, where, where do you think we ought to be going?" And we kind of packaged all of that into ten strategic goals which we're now working on at a very regular basis through our leadership team. We're assessing ourselves on the quality of what we're doing, on the progress that we're making. We put together a rubric of, of a one to five grading scale for ourselves, we don't have any fives, and we only have a couple fours. We've got one thing that's at a one. So, I, I wanted us to be kind of hard on ourselves to say, "To go from this two to three, what kind of progress do we have to see before we can really say that we're at a three level?" One of those ten strategic goals deals with the uh, technology in the classroom and I've just used the illustration, Gabe, of trying to bring technology into the classroom exactly the way we brought the Bible into the classroom for science or history or literature. If you think about Biblical integration, I use the term here, technological integration. I said, "You know, I want the teachers to think of it that way that technology will become such a common, routine part of my teaching that access to technology, interaction with technology, the kids have it, I have it. We're doing the smart boards, we're doing the iPods, we're doing the, whatever it is that we're using technology to teach our students and that just becomes just a common medium between us just as Biblical integration would be. We wouldn't think of teaching history class without the Bible 'cause that without that being saturated with God's word. I want us to look at education, the crape of instruction and saying, "We're gonna saturate this with technology." Probably a final thought would be uh; one of my favorite areas to work with is young teachers fresh out of college, that pre-service teacher education, kind of that junior year of college to about the third year in the classroom. In fact that's what i did my dissertation on. And when I did my research one thing I found with young teacher and Gabe, you're young enough, you can probably relate to this. How old are you now? Are you...?

GP: Thirty-seven.

JF: Thirties? 
GP: Thirty-six.

JF: Thirty-six. Okay. The one, they say one of the frustrations of young teachers coming out of college, whether its public school or Christian school is they don't have the access to technology in the classroom they had at their college. So, let's say you and I go to Cedarville as undergraduates, we graduate in 2011. Cedarville's a pretty techno-savvy type of school and the education department, I assume has followed that lead. And now we go out to teach at a small school, maybe a Christian school or some small public school like, you know I was involved, not in public schooling but in New Mexico for fifteen years. There are still small public schools out there with combined classes. Wyoming, some of the western states, Montana, if your child's is with second grade probably be in a combined first-second, second-third combination grade. You'll, so you go out and you're teaching those types of smaller schools that aren't quite as well funded. And sometimes the teachers just don't know how to teach 'cause they don't have all the technology that they had during student teaching or as they learned. And so they almost have to be re-taught how to teach without technology and they say that's a frustration of young teachers. And I've seen that here with our teachers. We hire somebody 22, 23, 24 years old, there's a certain level of expectation that we have this type of equipment, that type of access, and of course we have smart boards and of course we use online grading. "You mean I can't access my desktop from home?" We just went to that this year where we're giving all of our teacher's desktop access. And I have it and I love it. I, I can, I can access my computer from home just logon to a certain thing and anything I have at school, I have now at home without dragging a computer home with me.

GP: That's great.

JF: So those are just some things I think that I've uh, I would point to those two areas, Gabe.

GP: That's great. Are there any key issues that you think most divide teachers and students in the 21st century?

JF: Hmm. Let me chew on that one for a minute. That's an interesting question. So, key issues that would divide students and teachers? I think when the kids feel like they're not genuinely accepted. Some adults especially as we get older, its tougher to connect with kids, I see this in administration to where I was, when I was a younger guy in my twenties and thirties and I was in the classroom on a fulltime regular basis there was that natural connection with the kids. I was coaching, I was teaching, I was involved in different stuff, the social studies department and I was I was always out on campus doing something. Now I spend a lot of my time in an office and I walk into a classroom and I, I, I uh, I like to substitute teach at my campus. I'm a history teacher. So the Social Studies people know if they ever want me in the classroom for a couple of periods, it's probably an automatic, "Yes." I love to still teach history. In fact I just did that right before spring break I taught one of our world history classes for a period when the teacher needed to be out and it's tougher, it's a tougher connection now 'cause I'm a little older, I have to work harder to understand the lingo, it used to be my lingo and now it's there lingo. They don't see me very often. [Clears throat] Typically they see me at the community events like games and things like that, they see me at chapels when I speak, if they get in trouble, they're in my office, if 
they get to my office they're probably getting suspended or expelled, and so I just don't have that interaction with it all that much. It's just, all that to roll that back to your question, I think for the classroom teacher just to say, "You know what? I'm accessible, I care for you, I love you." There, there, there's a powerful thing about genuine Christ-like love and I've seen teachers who are maybe not the most socially adaptable sometimes. [Chuckles] Maybe a tad bit inept in that area but they're good people and I've seen the kids warm up to them, takes a a little bit longer to do it. But, it's interesting the way Proverbs talks about, very loosely interpreted, that kind of cream rises to the top type of thing that integrity, that honor, that respect, that righteousness just has a way of lifting to the surface. For some people it happens really quickly for some people it takes some time but I, I think that can be a dividing point if the student just doesn't have that comfort level of, "here's a quality teacher," They can handle their classroom, "but they really care for me. There's some sort of personal connection there." And for some teachers it just becomes almost automatic, they just walk in with it and other teachers have to work a little harder at it. And I know that's a relationship thing. Trying to think of something else that would be dividing; I think that to me would be the main thing. You know, I think, again assuming that you have a good teacher in classroom that's competent I think any student is always gonna be drawn to someone who genuinely cares for them but the love of Christ is a powerful thing and when it's displayed and modeled and poured out on somebody, it's pretty irresistible in a lot of ways. So.

GP: Good answer. Are there any specific steps you feel must be taken quickly in Christian schools where you are or that you've maybe been involved with accrediting that would bring about the type of learning environment you see as most beneficial to modern students?

JF: Let me start globally then kind of come down and narrow that down a little bit. I have been a long term advocate that groups like ACSI, I love ACSI, they're a wonderful group, I've done a ton of volunteer work for them over the years and I'm willing to do more if they need me. But I, I, I have lobbied regional directors for years that we need to have lobbyists for each region of ACSI. WE are just getting steamrolled by the public, not the public school system but just by state government sometimes. We have nobody out there that has a unified voice for Christian schools. Regional offices do their best; they're overloaded and understaffed half the time. I look at like, here in Ohio for example, is the Catholic league, the Catholic schools actually have an organization that they go out and hire a lobbyist. It's amazing what they get done in Columbus; I saw the same thing in Santa Fe, New Mexico. So as Christian schools we try to ride on the coat-tails of what the other private schools are doing and sometimes that's okay but sometimes they don't represent our opinions at all on different things. So, I think just globally as an administrator that's something I have said for years to a group like ACSI, "I would be glad to pay more membership fees every year to help pay our portion of a full time lobbyist to be working in the state capitals to advocate for Christian schools.

GP: Hmm.

JF: ACSI just, they do what they can nationwide but they're really the best they can do is provide information but then the information is there and there's a call to action and the only solution is to write a letter to your Congressman which we all know doesn't get read. You know, they get a list of how many 
inquiries they had that day and you know, the President of the United States is not sitting down reading a personal letter for me you know [Chuckles] He should but i understand they don't. So, I look at that and I think that's a real weakness that Christian schools are going through right now and I think that these large school associations like ACSI, CSI, and ACTS and some of these other Christian groups, uh, ACST, the Association of Christian School Teachers, it's an Assemblies of God group. I think they need to get it together in that. So, that's kind of a global thing. Give me your question again, Gabe, I remember most of it but...

GP: Sure, are there specific steps you feel must be taken quickly in the Christian school to bring about the type of learning environment that you feel is most beneficial for modern students?

JF: I think, I think my other answer to that would be that it's time that some of our schools have their acts together too. I think that for some Christian schools to continue to function in a mediocre level, I think it needs to get to the point that that's unacceptable. I understand small schools, I understand schools with no money, that's how I got started, I'm in a school now with, a little bit more affluent although we struggle with budget like everybody else. But I started, I cut my teeth on a small school of 115 kids in Pennsylvania, one took mission school of about 35 kids when I first became a principal and we watched that school grow with, but one of the reasons we grew is, because we turned into a more professional school. Going back to Dr. Lowrie's statement, "the student shouldn't have, taken academician to make backseat to receive a Christian education". So I think that would be the other way I would answer that question, Gabe, is just, so schools that continue to go out and to hire unqualified teachers, I think that needs to stop, I think of not doing our own curriculum development work, I think that needs to stop. I think we just need to, as a school system, as God's school system, I think there's just a real need there to say, "You know what guys?" For some schools, "It's time to step up to the plate and be more professional and stop, stop doing some of the things you're doing. It just, it just makes us all look bad." And think that does have an impact on the learning environment because when a school is in chaos or when a school is drifting or a school is stagnant, it definitely affects the learning environment. The school or church ministry should be dynamic and thriving where people are glad to be a par-, where people wanna be a part of it and when you have that that will trickle down to the classroom. That energy will get down to the kids and this is a poor illustration but I'll finish this question with this thought. I read a lot of textbooks when I was in grad school and don't ever tell any of my teachers this; I don't remember a whole lot of them. [Laughs]

GP: [Chuckles]

JF: I must have learned something I guess, I got my principal's certificate, but anyway, I remember a quote out of a secular textbook when I was a student at Grace Seminary in the Christian School Administration Program there, a public relations quote. And it said, "Money flows to promising programs not to needy institutions." That's the one thing I remember of that whole textbook and I remember highlighting that thinking, "Oh that is a great way to say it: Money flows to promising programs, not to needy institutions." And replace the word money with whatever you want to. School growth, higher academic learning, a better team, a better record, a deeper richer bible study, flows from 
a promising program not from a needy institution, that concept. And I think so many times ministries can fall under that word: needy organizations. And you know, be a promising program, be, and you can have 50 kids in school with a budget 500,000 or whatever a small budget may be for a school and you can still do it, it has nothing to do with size or money, it has to do with professionalism, intent, work ethic, standards, personnel, those type of things. I, I would rather have a group of eight dynamic, love the Lord, well qualified teachers then I would a group of 50 who just don't' understand Christian schooling. I'll take that group of eight teachers; we'll go out and build a school together. That's what you build your school on and they will become the school of 3 or 4 or 5 or 6 or 700 someday if they're on the right, if they have the right demographic areas where they're at. Anyway, that's my soap box analogy.

GP: No, I like it. You speak quite a bit about teachers and their impact, if you're involved and I know you are, involved in hiring processes, what qualities or characteristics do you look for in applicants to provide students the kind of education you've been talking about?

JF: I would really go back to those three things George Barna said, I actually look for those as I read an application or as I hear people talk, those three things are they called by God... does this person have a ministry call on their life or are they just looking to get away from the public school, they can't find a job? It drives me crazy, you've had these phone calls too, and somebody calls and says, "You know I went to college for a couple of years. Can I get certified to teach in a Christian school?"

GP: Hmm.

JF: I hope that the answer to that is, "No." [Laughs] It should be. Our students deserve certain, trained teachers in the classroom. But Barnet talked about that being called by God, having that true ministry call, and I ask people that question. "How has God worked in your life to bring you to this point? I want to hear that dynamic. I want to hear those stories of you know, "I was at camp or I was studying in a Christian school classroom, I was in college, I talked to my professor one day, I was in church one Sunday morning, I was flipping through Romans, I just felt like God was talking to me." I love those stories because that means the Holy Spirit is on the move. We've all seen the Narnia movies and you know when Aslan is on the move, you know, when God is moving, I knew a Southern Baptist pastor in a little church out in the desert in New Mexico and he would be telling the story in the bible about something, and he's kind of building up to, "Oh well this doesn't sound so good biblically here." That'd he'd always step back from the microphone, he'd get this grin on his face and he said, "Then God showed up." I always loved it when he said that. I thought, "Here it comes, here it comes!" [Chuckles]

GP: [Chuckles]

JF: He said, "Then God showed up." In other words, when God shows up you know it. And when God is working in somebody's life to bring them into ministry, they're either gonna get into ministry or they're gonna explode; you know, so to speak, that'd a poor way to say it.

GP: Heh. [Chuckles] 
JF: But they are so passion driven to serve Christ, that's why I want them teaching my kids. So that's the first one, they're called by God. Second of all, they're kind of Christ-like characters, these characters, Christ-like characters, not characters; these are people I want my kids to be like. These are coaches that I hope my son grows up to be like him. Those are the type of people that we want, so that Christ likes character and number three, functionally competent. I want the math teacher to know what he's doing. I want the third grade teacher to be really good at language arts because my little girl needs to know how to read well, my little girl needs to know her fifty state capitals, my little girl needs to know the Books of the Bible, and they need to know those things. So I'm not willing to trade off any of those three anymore and I feel that that's one of the reasons why, I think if schools adopt that philosophy, and again, this my opinion only, i think they'll be a stronger school. And I'll tell you what, as a parent, that's the type of teacher I want my kids with. I don't care if it's youth group, or fourth grade class, or high school soccer. That's the type of adult I want hanging around my kids.

GP: Hmm, very good. Can you tell me a time, John, that you felt most positive about your work, where you believe your goals, values, et cetera, in Christian education were being just met on a very high level? Is there one time that maybe stands out or maybe a few pieces that are a montage?

JF: Uh, yeah. Interesting question. [Clears throat] You know, I just uh, you know me a little bit, Gabe; I know but I just uh, I love what I do. I was born to be a Christian school administrator, I just believe that. I don't know if I'm any good at it or not but I sure love to do it. I just can't see me doing anything else other than what I do. I've been doing it for twenty years now in administration, or nineteen years now, I still like it. I'm still juiced about it, I still go home at night and lay in bed at eleven o'clock at night thinking, "You know if we did this instead of that and maybe if that person, maybe that would make us better next year."

GP: Mm hmm.

JF: I just like the, the strategy of administration I guess. But if I just had to point to maybe one thing, that's a tough one. Let me go back to my mission school days and I've shared this illustration with people before. We were support raising missionaries so for six weeks every summer we did deputation as, as stateside home missionaries in America, we didn't have one year every four, we had six weeks every year. And as teachers, course we did that in the summer, we took vacation and we went and did what missionaries called a "Tin Cup Parade", you went around the churches raising money. And that was hard for me to do at first but God kind of helped me work through that and reading some materials from Navigators and some of the writings of Paul about why we ask for gifts and things like that, really helped me mature through that as a young man, I think. But uh, for six weeks every summer my wife and I would travel all over the Midwest with our slide projector, like missionaries did in those days, and we would tell people all the good things that happen in the school. When's the last time a missionary got up and led bible study? That's been a flop so nobody's even interested. Boy that evangelistic thing we've been doing, I don't even care about it myself hardly. That's not what we talk about; we talk about our success stories. And everybody realizes even missionaries have a few failures too, we're normal people. 
But I would spend six weeks every summer telling people the good things that was happening at Hilltop Christian School out on the Navajo reservation...

GP: Mm hmm.

JF: ... about this family that came to Christ, or this kid who was struggling academically and we were really able to help him or this gift came into the school, our school was the first mission school in the United States to get ACSI accredited. That was a nice little feather in our hat, we worked hard for that. And I would go back to my ministry the first of August, so pumped and jazzed for what I was doing and it dawned on me years later 'cause I spent six weeks every summer telling people all the good things that happened and some of them, I'd forgot. But I'd have a slide of some little kid in September or whenever this happened or some chapel in Aug-October, and I'd forgot about it by June or July and it reminded me, "You know what? God worked in a mighty way." It was almost like a, a visual journal for me professionally and I would go back very wired for my ministry thinking, "Man this is great. I'm so glad to be a part of this. I'm so lucky God chose me." And it really was for me a very exhilarating experience. People that have never raised support, I know some people cringe at the idea but I tell you what, that was a blessing and I'm glad, I'm glad I didn't miss out on. It taught me to walk in faith, it taught me that God is Jehovah Jirah he truly is my provider. This school could come to me tomorrow and say, "John you're taking a $\$ 10,000$ pay cut next year." I would not be happy about that but that's what it is, that's what it is because you know what, this school is not my provider, God is. I, I, I learned to get a point of release in my early thirties in that whole concept that my employer is my provider, God is my provider and he can provide and do anything that he chooses to.

GP: Hmm.

JF: And again when God shows up, cool things happen. And i just really have that confidence, now my checkbook and my wife, may feel differently [Chuckles while speaking] but if my school board president came in today and said, "John the budget just has to, you gotta take a $10 \%$ cut next year." I wouldn't quit my job over it. I tell you, "You know what? God is using this to make me stronger somehow, to make our school better, and uh, my confidence is in him."

GP: That's good.

JF: So I, that's probably a roundabout way to answer that question Gabe, I can't point to any one point but I think just that experience that I had raising support and doing dubitation (?) six weeks every summer just driving, I remember there was one month we were in eleven churches in a month and that's tricky to do on four Sundays and there's only so many Wednesday nights.

GP: [Soft chuckle]

JF: I remember one Sunday morning speaking at a church in Dayton for Sunday school and church and that night at six o'clock we were in Dayton, err at Cleveland or seven o'clock, whatever time the church started. 
GP: Mm hmm.

JF: We were burning rubber up 1-71 that day. [Laughs]

GP: Yup.

JF: But it was fun and we were a young couple, we were serving the Lord, we were fresh out of Christian school. It was a great adventure and it's, uh, I, I'll never; I'll never regret doing that.

GP: That's great. Yeah, Dana and I have some great stories of our times, uh, raising funds for uh, our mission in Romania and telling the stories around Atlanta and the surrounding areas and all throughout the Midwest and other places we travel. And uh, actually one time a couple actually gave us a Mercedes to drive around, granted it was an older Mercedes, but there we were a missionary couple with no money of our own other than what God provided, and no car and we called it our "Ministry Mercedes" it was kind of fun. [Laughs]

JF: That's right, yeah, you know, it's sad Gabe and this is probably off the record here, but it's sad in a Christian school that some parents would just be horrified if God called their kids to missions and I just, it just drives me crazy when I hear that because they want them to be successful, you know, they want them to be doctors and lawyers and like God never used a doctor on the mission field but I tell the kids when I speak in Chapel all the time, I said, "If you want the thrill of your life, if you wanna live on the edge, you wanna be pushed professionally and spiritually," I just said, "even financially, go be a missionary." It was one of the most five exciting years I've ever had in my life. I'll be honest with ya, I miss it sometimes. I miss that sense of comradely when we all lived in the mission compound. Our kids were best friends, missionaries were your neighbors, you know, local Navajo people that had come to Christ became part of that family. We became part of their family. I still have some very dear friends of mine that are Navajo men and we email back and forth and I miss these guys. [Car alarm sounds in the back ground] They were good friends.

GP: Mm hmm.

JF: You know, we went there first of all to a, share Christ with them but you know, they became, we became buddies too and a guy named Eric Pedro, the guy who was from the Acaba tribe, his wife is Navajo, he's Acaba, he and I coached baseball together. We started a baseball team out there on the reservation and Eric and I still joke about baseball stuff. He's a Cubs fan, I'm a Reds fan, you can imagine where that one goes. But those were good days and I feel very blessed to be back involved with the mission, I now chair the mission board out there and in fact I'm going out there this weekend and I just can't, almost, I almost can't wait to get back out there. I just really, God has just given my wife and I a passion for that and I've learned that when God gives people a passion or a people group or for a ministry calling, he never takes it away.

GP: Yup.

JF: You know? 
GP: Yup.

JF: I think I'll be watching Christian school basketball scores in the newspaper when I'm ninety-two someday in a rest home. "Oh hey a Christian school won, alright." [Chuckles]

GP: [Laughs] that's good. Well, John, how do you think that the methods that you've been talking about as we've discussed several things today, how can those methods be brought really into the methods of our current Christian school educators, if you were to find a way to bring them forward to other Christian schools, what would you do?

JF: Well, actually that's exactly what I wrote my thesis on to be honest, my dissertation. It was a site based training model for pre-service teachers and what i was trying to tap into out in New Mexico where there are so few Christian colleges is that so many times we get Godly Christian people coming into the Christian school who have never been trained to be Christian school teachers. They've gone to the secular college, they've been taught the secular way. It doesn't mean that they've embraced all of them but that's what they were taught and they were exposed to. And again, you spend four years in an institution, when a student is fully trained, you know that gate swings both ways. If I put my children under the training of a secular ungodly person or system, I should anticipate that to some extent they will become like their teacher. That gate has, swings backs and forth. The Bible says not to be deceived that; "Bad company corrupts good character." I gotta be careful as a parent I don't expose my kids to bad company and bad character 'cause they model that in some way. So as I go back to that I think that's a, I think that's a great need in our Christian schools that we need to have people that are not just hired at a Christian school but are trained to do Christian schooling. They understand the philosophy, they understand Biblical integration, they understand how to teach phonics which most colleges don't teach anymore and this is true even in some of our Christian colleges. People will lift their eyebrows when I say this but I've graduated from three Christian colleges now all wonderful institutions and I'm glad I went to all of them but as I look at Christian colleges around the country, some of our Christian colleges are bailing out on Christian school education. They are no longer preparing their graduates to work in our schools. They're preparing them to teach in the public schools. A good indicator of that is think of the, to pick up the catalog of any Christian college and see where their faculty members are coming from. And if they're saturated with public school people that will be the tone that will be set for that education department, will be secular education. Because again when a student is fully trained in that type of thing, it doesn't mean they're not good Christian people but it means that's the system that they felt called to, was secular education and they are going out now and they will teach future Christian school teachers how to be secular educators. And, uh, we have to be savvy in that when we go to hire people, again it's back to personnel, that's why those questions are so important, that's why that, I, I, I am no longer willing to be impressed with somebody who goes to a Christian college and I hate to say that 'cause I love Christian schools, Christian colleges. I want my kids to go to one but I'm gonna ask the tough questions, I wanna know where their heart is at, I wanna know where their training is at, and I wanna know what they're gonna be like here in this school. Used to be if, if an applicant was from a Christian college it was almost a drop dead deal, it was a hire. I don't feel that way anymore. I've had many Christian school graduates that I've passed over because I collect they just didn't understand 
Christian schooling, so I do it. So I either have to know that when I hire them or more realistically I have to be willing to train them once I do hire. That's why I developed a site based training model for preservice teacher education. And you know one of those long titles you put at the spine of your dissertation that your high school English teachers give ya a $\mathrm{C}$ for, cause your titles too long?

GP: Mm. Yeah.

JF: But we get away with it in grad school... [Laughs]

GP: [Laughs]

JF: ...uh but I, I, I, Gabe, you know that, you've heard that in the last forty-five minutes I can continue to go back to the heart of the teacher...

GP: Mm hmm.

JF: ....and to the skill of the teacher, and the passion of the teacher. I think that is everything. Give me a group of good teachers, we'll go out and build a good school. Give me the Taj Mahal and all the money in the world with people who just don't get it and just aren't driven by that passion, I can go out and build a mediocre school. It might have nicer facilities, you might have turf fields instead of grass, you might have all that but you're not doing Christian schooling.

GP: Mm hmm.

JF: Jesus never built a single building; he did some pretty good teaching under a tree one day, as I remember right, and on a hillside, on the temple steps. Christ didn't, wasn't a facility guy. [Laughs] Nothing wrong with nice facilities but I'll take good teachers over good facilities anyway because I know that's what's gonna impact these young people. It's not gonna be the basketball court, it will not be the science lab; it will be the coach and the teacher they put on the court and in the lab. That's what's gonna make the difference.

GP: Um, two final questions here: What role should parents be playing in the Christian school in the 21st century?

JF: I think, this is probably not answering directly but it goes back to responsibility of the school. I think we need to be teaching our parents about what Christian schooling is about. I've developed at a couple different schools now and I'm working on it here on a, on a new parent orientation process that we do. We make it part of our admissions program, your kids don't get into school unless you complete this hour and it's a half workshop and it's teaching our parents what is Christian schooling really about because many of our parents have not gone to Christian schools themselves. So that's kind of a caveat on the side. Give me your question again, Gabe. What should parent...?

GP: What role should parents be playing in the 21st century Christian school? 
JF: Okay. Again I think we need to make our parents well educated consumers of Christian schooling. I think the role they should play obviously should be one of support, one of consistency, Christian schooling is at its finest when the home, the church, the school, that whole triangle, that three-legged stool, we've all seen those old illustrations in the seventies but that it's still true, that's when it works the best. So I think the strongest role that I can play as a parent is that I model the behavior, the academic expectations, the spiritual nurturing, that what my kids see at the good Christian school they see in my home that the kids see no difference between dad and coach Gabe here with the wrestling team, you know that that same Christ like character, that same level of competency...I think that's a great role that parents can pl-play. I think that parents need to be prayer warriors for their own children, some are, some are not to be honest. I think parents need to; they need to do their job as parents. I think they need to help their kids make wise choices. I've seen this more and more every year, Gabe, and the older I get, we've got some of our elementary kids that are so incredibly busy they almost need a personal secretary to handle their schedule.

GP: [Chuckles]

JF: We wonder why they get labeled ADA- ADHD and we wonder why sometimes kids are understand that.

GP: Mm hmm.

JF: We wonder why they fall behind in their studies, we wonder why they fall asleep in class because the parents have put this rat race lifestyle that they live, they've put that same expectation on their fourteen year or the seven year and many kids fall apart under that, they can't handle it.

GP: Yeah.

JF: So I think as parents, I think we need to be willing, we need to help our kids say, "No." and we need to say, "No." sometimes. That comes to me, I, I'm a classic over-committer, my wife'll tell you that in a heartbeat. That uh, if you would ask her, "How could John make his life better?" she would probably say, "He needs to give up about two activities." She's probably right. I just can't decide which two to do so uh... [Chuckles]. Or which two not to do.

GP: It's difficult.

JF: I like to be busy.

GP: It's difficult.

JF: This is uh, maybe borderline sac-religious, if so I apologize, I always say, "When they lay me to rest someday, I might as well be tired." [Chuckles]

GP: [Laughs] Yeah, no doubt. 
JF: I wanna work hard in ministry and when God takes me home, they lay me to rest, I wanna be really worn out and tired from the ministry.

GP: That's good. A good goal. Well I know we've talked quite a bit, thanks for sharing all your insights and wisdom. I really appreciate that and certainly there are some key things that you came back to and you mentioned regarding just the centrality of the teacher and their Christian walk and certainly, just uh, the Holy Spirit's work and the work of the word. So, are there any other thoughts or things on your mind for transforming Christian education in the 21st century that you'd like to share with me now? Maybe books that you've read or articles, ideas that you'd like to share, things like that.

JF: Maybe just a final thought would be along funding. You know, I, I'm an advocate, in fact, one of the first things I did when I came to Worthington Christian, we started to lay the groundwork to start a foundation, in fact that'll get launched this summer. We've got all the legal stuff, the attorneys, the bilaws, we, articles, everything else we've gone through that we're developing a separate 501 to have our own foundation. I am a firm believer, Gabe, that Christian schools of the future and probably even right now, in reality, will not be able to meet their mission to do what they need to do if they depend only upon tuition and fees, you know what they say the "Big Three" in Christian schooling: tuition, fees, and fundraisers. We've gotta adopt more of university model style of funding. We need to get into estate planning and wills and large gifts and just, so we're, we're hiring for the first time ever next year a foundation director for our school that will take this new foundation and will go out and will be soliciting and working with donors and talking with annual fund type of people and just really helping us build a stronger financial base for the future. So I think that would be something I would, I would encourage a school of any size to look at because there are people out there, you know I think that when we don't have a lot of money ourselves, it's easier for us to think that nobody else does either but I have found that not to be the case. Just because I'm not wealthy doesn't mean that God has blessed somebody else that way.

GP: Mm hmm.

JF: And there are a lot of good people out there with good hearts that are looking for a promising program, cause that's where money flows to, not to the needy institution, there's a reason why they have wealth, they were smart with their money. They're looking for promising programs to invest in eternally or something that will help children or something that will, will kind of leave that spiritual legacy. We're advertising right now, it's interesting the feedback, I've got a little way that I won't go into detail on of how I try to get feedback on how successful, or how much impact our radio marketing is having and it's pretty casual, I don't know how scientific it is but it, I like to get the feedback. And we decided there's a, a radio station here in town that is really not contemporary Christian, it's listened to by the grandparent generation to be honest. We used to do a lot of advertising with it and I look at the ratings and found out that we were getting good deals on the advertising but nobody, none of our parents were listening to it so we switched stations and uh [Chuckles] but we decided to go back to this one and we started to market grandparents because so many grandparents are involved in their kids, their grandkids Christian schooling whether they pick them up after school, whether they pay the 
tuition, whether they're praying for them, whether they're talking their kids into it or whatever it may be and so we've actually started to, by radio, market our grandparents and talking about legacy and talking about tradition and how they can pass on their faith values to their grandchildren. And they say a great way to do that is through a Christian school education, helping your grandchildren gain a Christian school education. Our school is probably like your school, we have grandparents that are raising the grandchildren, they have become the parents for different reasons. So, I look at that and go back to the idea of just a funding formula. I'm firmly convinced that our Christian school needs to [long pause] adopt more of university style model so to speak. I don't think we can get where we need to go in the future just relying upon tuition and we all know there's a saturation point as to how much tuition we can charge.

GP: Definitely. Good thoughts, thanks for sharing that.

JF: You're welcome.

GP: Well, I know we've talked quite a bit and you've shared very well and I appreciate it. It's amazing how many, you know, commonalities there are between the people that I've mentioned, that I already interviewed and you. So I'm looking forward to looking over the research and seeing what comes together as far as key points on these questions and I really appreciate you taking time to talk with me and certainly have personally appreciated just time working with you for a little while at Dayton Christian.

JF: Nice, your welcome and uh, good luck to you Gabe. I'm excited for what you're working on. This sounds like you've been tied into something with some real meat to it which to be honest a lot of grad school students don't. If I get one more phone call that some advisor has allowed a student to do research on the impact of school uniforms I think I'll scream.

GP: [Laughs]

JF: [Laughs] that one's been beaten to death. It sounds like you found something that hasn't been beaten to death and congratulations on that.

GP: Thank you.

JF: That's easier said than done at grad work. 
Title: Phone interview with Bob Gresh

Date/Time Recorded: 4/14/2011 2:06:00 PM

Record time: 1:05:29

GP: Okay, so I'm here today with Bob Gresh. Bob, can you tell me a little bit about your school, the name of your school, and the title and position that you hold, what that means at your school?

BG: Well, I'm the head of the school at Grace Prep School, State College, PA. I founded it in 2004 so I started it with my wife and we're grades nine through twelve. We're unaffiliated, independent from any other church or denomination. And, I'm a businessman by trade not an educator so I have kind of a different perspective on how to do things.

GP: Okay. Very good. Well I'm sure that our educational world specifically in Christian schooling could use some business minds...

BG: [Laughs]

GP: I'm interested in gaining your thoughts on the development of improved learning environments for the 21st century Christian school and how you have developed or hope to develop your goals in Christian schooling. I'm also interested in hearing about the core values and beliefs that embody your work, as a, I'm gonna say Christian educator here, because you've brought yourself into the trade.

BG: Right, right.

GP: And then you know we can, we can talk about some other things along the way as well. Question one: What are the key elements that you believe should set Christian schooling apart from secular schooling especially in the 21 st century?

BG: Well I believe that grace should set it apart. Generally, I started the school based upon two things or three let's say. One is a belief that, well, a number of things; one is that my student, my kids are going into ninth grade, my son was and we have a high school in town, public school. Now he's brilliant, he's a Shreir's scholar on scholarship at Penn State in Engineering Science. You know, valedictorian of, of the school but the high school there had 2700 kids in it, and I just felt like, with Robby, he just wasn't the kind of climber or had the kind of personality that was going to, you know, practice every day a sport to become on the varsity team or just climb over what he needs to do to get the kind of opportunity that he wanted. So, I felt like the smaller school environment could, could allow kids to get more of a variety of experiences without, and kind of a way that they were experimenting. In other words, they could put on a uniform, you know on the basketball team, without having them on travel team and committed to the last six years of basketball. They didn't have to make as many choices that led them down one road, they could play multiple sports. I mean in our school district very few kids play multiple sports because if they wanna play football, they have to be pretty committed to football the year round. So I didn't think 
that was healthy, I thought that for instance, our sports program, every kid should have an experience in his life where he put on a uniform, you know, wins a close game, loses a close game and feels that team is a group of commrades. That's what we talked about with the sports program. So, one of the, my goals was to get students to find their passion by being able to experiment different ways without having to commit to it for, you know, the major part of their life. Two was based upon [clears throat] my wife's ministry and our ministry in purity and one of the, I remember that, about five or six years before I started the school, Dannah talked to me about a girl that she had met at a purity retreat that she was doing. The girl was pregnant and had confessed and was at church where the church made her confess in front of the church, you know, and she said, "I confessed to my family, my boyfriend's family, my church and I wanted to come to the retreat to learn more about purity." So I thought it was very moving and then she added by saying, "And I'll be kicked out of my Christian school on Monday."

GP: Hmm.

BG: And I never forgot that, I mean, I think it was a God calling on me. I never thought to myself the first time, wow that's kind of, that's kind of how that works. Like, thought through my memory and thought, I guess a kid that gets pregnant in Christian school will almost in every case get thrown out or put on some parallel curriculum to kind of get them out of the, the way and I wondered how that conversation went with the Christian school administrator and her coming in and saying, "I messed up." Crying and you know it's the worst thing in her life and him saying, "Well," I mean I'm trying to fill in the blanks of what he would say, "Well, this is your consequence you know God still loves you." And I felt like that was completely ridiculous, however that conversation went that meant her leaving, I felt like was, incredibly impossible to square with the scriptures. If she's, if she or he confesses and has repent, then generally what we do, for instance with those kids, is we, if they get pregnant, we kick them out of school, you know, not we but the Christian school environment in general because I guess the premise is that we don't want kids, you know, catching the, the, thrill of pregnancy.

GP: Huh.

BG: And so what we do is we hide them for a year or nine months and the next time the kids see that girl she's holding a little baby and, you know, she doesn't, I mean you can't say I regret it at that point you know. The school didn't get a chance to walk through that with her which is important for the kids who are in that situation as for the girl who is. So, one of my goals at Grace Prep was to have kids like that thrown into the school, and not out of the school, if that makes sense.

GP: Mm hmm.

BG: And at the point where a public school teacher says to a pregnant girl, "You really need, I think Grace Prep would be great for you because you can really love you more than we have actually resource to do that."

GP: $\mathrm{Mm} \mathrm{hmm.}$ 
BG: So, it was also, to be transparent with you, the grace model was based on a personal failure in my life with pornography and being removed from a position at a church and I got that, you know. I confessed to it, I came forward on my own kind of thing. I had just been hired to be the headmaster of a Christian school and I had written a marketing plan for the school and they liked it and they said, "Hey will you run the place?" and I'm like, "That'd be kind of cool. I think I can pull this off." And became very successful at the school and then fell in this way even though I had been, you know, telling the church about it and been accountable, they'd been walking with me but anyway it was kind of a, it wasn't a matter of getting, you know I resigned 'cause I knew they were going to have a hard time, you know it was just hard for them to fire me because I was very popular there. And so that was not a problem for me, it was very hard but I got it, you know. But then I was kind of shunned afterwards, I realized what the process was like, you know it was like, and all the sudden I found myself on that side of the conversation where the pastor said to me, "You know I think it'd be better if you found another church home. And I was like, "Wow. This is the conversation." and I said to the pastor, "No, no I fit in here authority wise, biblical wise and I need to be restored here, I mean, not to my job but you know, just, restored." And they looked at me kind of funny and was like, well, well, you know they didn't want me there so I ended up going through the process there and said, "You know you can transfer me to another churches jurisdiction or, they didn't really wanna do that so I went to their, that church for a year. I felt, it was a good past story to the families that were upset at the school, and [mumbles] if they can't be upset. I did this, it's on me. And I realized that, that's kind of what we do, you know?

GP: Mm hmm.

BG: And that really broke my heart cause I knew what it did to my life so, I started Grace Prep because, you know, what I was told at that point is that I was kind of, you know, they wanna protect the flock. And in my life what I realized and one of my core things with Grace Prep is Jesus left the ninety-nine to save the one, so he left the protection of that flock to save the one because it's always the one. It's always about the one. And so, you know, that's how we kind of operate. Let's see, the other thing I started the school because I felt like there were kids that unlike [banging in the background] the great inventors of our time, the great business people of our time, our kids have never finished school or finished college. And I thought, how is it that we can't engage them and they are being this failures all the way through the educational system when actually these are the kids that are hiring the, you know I always joke about at Grace Prep, you know, I was the ADD kid that didn't get very good grades but you're all working for me now so, you know that's kind of the joke around, around...

GP: [Chuckles]

BG: ...the school and, and just to go off on that a little bit, so I don't forget it is, I recognized when I hired teachers and I hired the best teachers, I looked at them one day because they really felt those ADD kids were lazy and they didn't do their homework. And, so that's like the, it's hard for you to understand 'cause you always did your homework and I realized that I had hired all the best teachers with the best resumes and curriculum vitae and master's degrees and I thought, the nature of a good teacher generally is that they do things that they're told to do because they design their curriculum, they come 
to school every day, at the end of the year, they start all over again. So a second grade teacher or a first grade teacher is teaching a kid to tie his shoes, gets through that whole year and then next year there's a whole new group of kids that she needs teach to tie their shoes all over again. And an ADD person, or someone like me that would be just, like, hell on earth, like that would be the worst thing ever to do the same thing over and over again. And I realize that, but to like a teacher I said, like, "You actually were the good, you were the, you were the kids in class who were always wrecking my curve, you know, you were actually studying and the teachers liked you," and so it was a little bit hard for them to understand as Godly as they were, as compassionate as they were, it was a little bit hard for them to understand why a kid kind of just knowingly doesn't do his homework. And I, I understood that kid and so we've kind of negotiated back and forth between me and the teachers of you know what's the line of what they have to do and what they just have a really difficult time doing. SO those are the three things that, I think they were in there somewhere...

GP: [Laughs]

BG: ...of why I started the school.

GP: That's great.

BG: If that makes sense. You're gonna hear, I may be different than your other educator interviews 'cause you're gonna hear an ADD person talking to you, so.

GP: Ha-ha. I like it, so far so good. Well, Bob what specific needs of students in this generation stand out to you as unique or even different from past generations?

BG: Well, um, [Long pause] I'd say one of their needs is to sometimes just do things because they're told to do them. We also try to develop, you know one of our points at Grace is, is, you know, we think, "Why do we have to learn this stuff?" is a good question. So, we want them to question our efficiency in what we're doing but at the same time I think kids today have, are in a situation where, um, parents are friends more than parents. They want to have the approval of their kids more than they did in the past. We as parents tend to have our lives revolve around the kids more than they, parents did in the past and that's a good thing to some extent but I, it can become idolization of your kids, you know. Break down, for instance, an antic that would be kids today I don't think are nearly as excited about getting their driver's license [mumbling] the kids in our schools used to be. They get their driver's license at seventeen or whatever. I think why do they do that? Well, because we as parents are driving them around everywhere. Whereas when I was a kid, I, I just didn't go place-, I mean there was just, some things where mom and dad said, "No. I'm not, we can't go there. I, I'm not gonna take ya." So, I think that they have a need for that kind of discipline and realize that sometimes you have to do what the authorities say because it will help you be successful in life. You know, just to kind of come under those parameters and, and really respect, there's a real lack of respect from kids today.

GP: Mm hmm. Okay. 
BG: If that makes sense.

GP: Definitely.

BG: 'Cause the question was about needs.

GP: Yeah, specific needs, you know, that students have so- to boil it down, you said basically they need, they really need approval of their friends, discipline, and then respect issues. Disciplines in coming under, you know what proper authorities say and that type of thing.

BG: Right. I would say another thing would be there really seems to be a sensory information overload. They have a, a, they have a lot of knowledge that only adults had in the past because of the internet, because of the access they have to information but they don't have the ability to sift through that knowledge and be humble about, that just knowing facts sometimes isn't the best way to get from point A to point $B$.

GP: Mm hmm.

BG: If that makes sense.

GP: Definitely. Definitely. Do you think then with teachers there are two or three necessary changes that teachers must make to reach students in the 21st century Christian school?

BG: [Sharp exhale] Um. Changes that teachers need to make? Well, I think that, I believe that...one thing is that, curriculums, you know, one of our, one of our themes is "Prep for Life" and that students today are not being prepared for life because of disconnected fathers and the break-up of the family. They don't really, a lot of them don't have filters and boundaries, you know, they, they, uh, they don't know how to get, and this is because of what happened in my life, they just don't know how to [long pause and chuckle] they, they're not, let's see what do I want to say here? Let me think about this. [Long pause] Um, I feel pressure because I know the tape is rolling, so.

GP: That's alright.

BG: Um.

GP: Do you feel that maybe it has some connection to what you were talking about in the information overload, just the massive amount of things coming...

BG: Yuh-yeah.

GP: ....at them all the time?

BG: Yeah, and just you know that school, you know, for instance, you go to get a four year degree in accounting and you're not an accountant when you come, when you come out. You go to school for six years or whatever for law and you have to still pass the bar. You know, in my mind, the education law, that's really weird. 
GP: Mm hmm.

BG: Because that should be your final exam. I mean that's what you're going to school for. Now if you have to do an internship in there that's fine but it seems very strange to me and I think kids, for instance one of our things is we're developing forty core competencies. You know a kid can easily go and not ever learn like chess, not ever learn oddly enough the books of the bible in a church anymore, the, they'll, you, you'll see all the time, you know, they don't know how to dress formally, they don't know what to wear to a wedding, they don't know how to tie a tie.

GP: Mm hmm.

BG: Now that takes me ten minutes to teach 'em but nobody in a normal school curriculum will ever teach them that. So, how to change a tire, things like that is some of the most basic things that the parents used to teach, maybe not, but we teach them as part of this, a second curriculum, or additional curriculum.

GP: Mm hmm.

BG: I also find that teachers are constantly racing against the textbook to get the curriculum finished so sometimes education gets in the way of learning; you know there's a phrase that goes like that. My teachers are always, since they're, since they're wired to be good managers of time and stuff, you know, they need to get through these chapters of the book. And so kids can easily sometimes have a competency in what they're tested on but not really understand how it relates. And thirdly, half the stuff we're teaching doesn't relate at all.

GP: Mm hmm.

BG: I shouldn't say half, that's an exaggeration maybe but we're not learning broad themes of history and why things happen; why Iraq might look like Vietnam might look like Korea like, might, what these things mean and one of the things that I loved as a, is, uh, the thesis of a book called Guns, Germs, and Steel by Jared Diamond and the way, he as a sociologist kind of went through and used history. And for instance, here's one thing: you know, there was only one load bearing animal in North and South America was the llama. So the Indians didn't have horses, you know like we see in Cowboys and Indians, they couldn't pull a plow, they couldn't leverage their work. That was a massive change in how they could do things just because of the way their environment was. So, these are things that explain history a little bit better, you know, and his basis is that weaponry, disease, and natural resources are what shaped, what moved you know civilizations. I think that's fascinating.

GP: Yeah.

BG: And it makes a lot more sense than the one dimensional history that we tend to teach of particularly history I would say. 
GP: Good, well are there technological needs that you see as most essential to be taught in the 21st century Christian school? I mean, there's lots of stuff.

BG: You mean computer technology and stuff?

GP: Yeah, with all the technology out there, all the information are there core essentials that you guys focus on at Grace?

BG: I would say, ironically, and maybe, maybe this isn't a good answer... No.

GP: Okay.

BG: I think the one thing that amazing me is kids generally know how to type and they know their way around their computer and when we have technology courses we're teaching them things of theory and thing that, what they really need to know is, in my opinion, is the Microsoft Office application and how to use Google. Now just I'm just speaking off the top here but the fact is, you know, they, they know the technology in general. They've been raised on it. It's a, it's, very natural to them and so many think of technology, we don't teach technology courses because the kids generally come in knowing it, that's not something they don't know about. Now, if a kid wants to go into programming or graphic design that's something different but I don't find that to be, you know our paradigm is shifting even now to where I'm not gonna provide laptops anymore for students cause they almost all have them and so, you know, it's cheaper for me to buy a laptop for a kid and charge a $\$ 75$ dollar technology fee but what we do is charge $\$ 150$ technology fee if they use our computers and $\$ 75$ if they don't. And next somebody's gonna be like, "We don't wanna provide technology 'cause it's $\$ 300$ bucks. If have a family that needs one, there's gonna be laptops, you know, around or we could buy a Netbook for them for $\$ 300$ bucks." Generally the kids had them and we can save a lot of money by not providing twenty Macs like we usually do and, and when a cord is $\$ 79$ dollars we have to replace eight of them a year, and twenty batteries at $\$ 200$ a piece every other year, I can buy computers for ten kids with just the replacement batteries I'm buying. Every two batteries is a Netbook, so, I guess in answer to your question, I would say, "No." That they know how to use technology, it's second nature to them.

GP: Okay. And uh, what key issues do you think might divide students and their teachers in 21st century?

BG: [Long pause] Um, what key issues might divide students with teachers? I think that, in our case, we're a very transparent school, that's the nature of our ministry. You know, our teachers are not afraid to get up there and talk about how they struggle with pornography, how they might've had an abortion, divorce, and so they can relate to the kids on that kind of level. I think probably a lot of organizations can't do that.

GP: Mm hmm.

BG: You know, we've taught retreats at schools before where the school will tell us, "You realize that if they confess to something in this group," Because we have a mentor for every six kids in the small 
groups, you know, during the retreat, "that they would be held accountable for that." And, it's like, "Wow!" Our job at Grace Prep is to walk with kids in real time because frankly in my opinion, they're a lot like adults; they're stepping in piles all the time just like adults do. And if we can walk them, through them in real time and know that, they occasionally might drink and come and confess it to us, we say, "Well that was a stupid thing to do." you know that's better than kicking them out for catching them sinning because I wouldn't wanna be kicked out every time I sinned. And so i think of the need for teachers who are gonna relate on a transparent level with the kids and that's something that very specifically can be done better, I think, by a Christian school. I also think there's a need to look at the Bible more in a relationship way than in a, um, [pause] a technical way. You know, more talking about the apocrypha, all the, the, the very, you know, theological, what do I wanna call it? The educational theology stuff from the bible like a professor would look at it and a lot of times missing the relational stuff. You know, the, the relationship with Christ is, I think, sometimes overlooked as to [pause] kind of how relational he was. He wasn't like the pope who rides around kind of giving a cheerleader wave, you know, wave and a white suit with the white robe with the sheet all the time. I mean I think that's what the average persons, you know, image would be. I teach a lot about the temptation of Christ and you know when I say, "What was Christ tempted by?" People will generally say, "Well, he was tempted in the wilderness." And they'll name those three of four things." Well that, that's very hard for me to identify with. I'm not tempted by jumping off a cliff, okay? Those are very theological temptations which are very important but Hebrews talks about Jesus being tempted in every way like as we are. So, you know, was Jesus tempted to cheat? Was he tempted to lie? Was he tempted with lust? Of course he was. Was Jesus a frustrating/first rate "A" student? I don't really know I kind of doubt it. But our impression of Jesus is that he got a 1600 on his SAT's.

GP: Mm hmm.

BG: I sort of believe that if he did that he could relate a little bit less to me. So, when you challenge kid's beliefs on whether Jesus was, you know nobody knew he was God, and now nobody, and his brothers at thirty years old said, "What are you doing? You, you're acting like you're God?" So, it's very interesting to me to look at those things and make sure that Jesus is God to them but also you know understand him on a personal level. So I guess the answer to your question is I think that we need to, we need to teach the Bible in a way that, that relates them in grace but also has reverence and one of the things we're missing is reverence at the same time.

GP: Very good, very good. Have you made any suggestions, Bob, recently to teachers as to how they might adapt their teaching to reach today's students?

BG: I make, I make, and we're a small school with limited resources. Our problem is with kids on the lower end. Now economically when we pay teachers, let's say $\$ 6000$ dollars for an adjunct course, you know, one, one history course to teach outside and our, our students pay seven or eight thousand dollars a year on tuition, it doesn't pay for me to lose a student over not having a course. Okay, as a business man and so, what I, I teach a class every four years on politics and I am generally a terrible teacher but I like politics. And I haven't had a problem adapting my curriculum to every student and 
grading them on a level that's a little bit different. So what I've suggested to teachers lately is that we don't necessarily have grade inflation and we take our history course which we, generally is advanced history and we grade a kid that's in that same class a little bit differently and call it applied history which would not have the same weight on a college resume or whatever. You're not inflating their grade; they're taking a different class within the class. And I think that's an economical way for us to do it and I'm really, I'm really challenging the teachers constantly is, "Do they understand what you're teaching?" Some of our worst students can rattle off history than our best students. But they're just not gonna understand it the same way for a test and so I talk to them a lot about that. I, in our school since we're so grace oriented one of our challenges is to be formal enough and sometimes the kids, you know, like they call me by my first name. SO every teacher gets to pick out what they call them. So half the teachers are, you know, Mrs. Chastrick, Mrs. Campbell, and then I'm Bob and the history teacher is Dave and you know, and sometimes that can, that can really lead to too much familiarity. You know um, so, I talked to the teachers about the fact that the impact they're going to have on their lives, the kids' lives doesn't start tick- the clock ticking in the classroom, it happens outside the classroom while it's voluntary for them to talk to that kid. And when I ask parents and teachers to think back about their favorite teachers generally it might be a teacher that talked to you thirty minutes one time outside of class about your life and that's the teacher you remember. It's not as normal for you to remember as your favorite teacher just the person that taught you your academics in class. The time outside of class is so important which is why on Thursdays we have, our whole school is based on discipleship groups, we call them "D Groups" every teacher, which is, has five kids, they have to be able to fit in their car, if they have a mini-van, they can have six kids. We have a chapel on Thursday and a long lunch, an hour lunch and we take those kids out very week. They pay for their lunch but we take them out and we just talk to them, like whatever we talked about in chapel. But those are my six kids and I tend to have all the ADD kids, you know, and so we have a heck of a time holding a conversation but you know we went out a couple of weeks ago and they came over to the house and we shot skeet. My, my kids and my group love to play video games so a couple of times we had them come over and play video games and those are my kids. So I think it's really a cool thing at Grace Prep is, we have a church model where if a parent has a real problem and we have a kid that's really struggling, the "D Group" leader is responsible first because he knows that kid better than I can know the, all the sixty-seven kids. And, that kid has a personal connection to that teacher, they pick their "D Group" and they spend a lot of time with those kids outside of class.

GP: That's very good. Are there specific steps you feel must be taken quickly to bring about this sort of learning environment that you see as most beneficial, maybe in others schools, let's say a school like mine was trying to bring about some of the principles that you've talked of at Grace Prep, are there specific steps that we could take quickly to start to achieve that?

BG: Well, um, I think that transparency is a thing that brings kids together makes them relate and if you're relating to a kid on that hard level they're a lot more likely to work a little bit harder for you in class. I think that teachers have to focus on the competency of the kid, I mean, is he learning the material? You know he might be testing poorly so a kid, maybe a kid's failing, ok I'll be like you know, 
"Well he got all these three, you know, he's passed all of his tests and getting, not even getting any of his homework in. I'm like, "Okay is he understanding the material. I mean how we can work with that kid. He's different than other kids." Just as a side, we don't have any D's. I got kind of frustrated with D's and when I got to the point where I'm like, "why do we have D's? That's unsatisfactory. Why is that passing? You're putting on the kid's report card, "This kid did unsatisfactory performance." In my mind he didn't learn the curriculum, so why are we passing him? SO we have $A, B, C$, and F's and the parents love that 'cause we just explained that. Now next year I'm very likely to charge $\$ 1000$ dollars for an "F". And I explained this to my parents, the parents, "I don't want to pay for your "F's". I'm hiring all kinds of extra people because you're kids are getting "F's". If the kid has to work four to five weekends and he got an "F" or eight weekends, that, that's, that'll teach him not to get an "F" again. And I think that's gonna be kind of neat, my parents are totally supportive of that. We'll see, you know, how it works out in the end. But, uh...

GP: [Chuckles]

BG: I think that, I think the grace philosophy is very, I'm just meaning that in our forty points of grace thing, is very important because a kid can't be struggling with pornography and not be able to talk about. A kid can't have, struggle with drinking three weeks ago and not be able to talk about it. I mean, how do you get in that kids heart when he can't tell you what he's done without fear of getting thrown out of school?

GP: Mm hmm.

BG: I mean, he's having sex with his girlfriend but he can't tell you because you'll kick him out of school. What does that say about our relationships? Now, that makes you think differently. You know, what do you just let the kid go on sinning? No because if he's repented then it's something different but you know, um what are you saying in the opposite? I mean, if you sin you're gonna be cast out of the community. Now, the only thing we have is that every kid has to want to come to Grace Prep. I didn't realize that early on but the second year I realized that any kid that doesn't wanna come isn't gonna follow our program as a family. It's just not gonna happen. He's gonna be sitting in the back row with his hands folded being a rebel hero and I, as a business man that's not what I got into this for. You know? I mean, my house is mortgaged for the school. I don't, I'm not gonna spend a lot of my time and resources on kids that don't wanna be here. So, [sharply exhales] so, that makes a big difference and it's very powerful and at the beginning of the year there's sixty-five kids sitting around and I say, "How many of you wanna be here?" and every kid raises their hand, that's very powerful.

GP: That's good. So you guys interview them every year for their desire to be at the school?

BG: Basically, we can, we can tell pretty quickly if they wanna be there or not.

GP: Okay. 
BG: The most trouble [stumbles] I've ever gotten in with parents, I almost have no parent problems, the most I get in with parents, is a couple times when their kid wanted to leave and I supported that, the parents said, "This is the best thing that ever happened to my kid and you're allowing her to leave?" And I'm like, "Well, you know, she has to make that decision."

GP: $\mathrm{Mm} \mathrm{hmm}$. Bob, when you're involved in the hiring process for teachers or administrators, what qualities and characteristics do you look for in the applicants to provide... [Over-powered by Bob's voice]

BG: I want; I want them to be intellectually curious first. I want my English teacher to be an English geek, and my math teacher to be a math geek. I want him to be bringing me projects all the time. I'm like, "I don't wanna hear any more about math from you because it's boring to me." But I want him to keep doing it anyway...

GP: Mm hmm.

BG: ...because he loves the topic. You know? He needs to be reading things at home on his own 'cause there's no other way to do it in, in your work time. Our teachers work during the summer. So that weeds a lot of them out to begin with because when, as a businessman when somebody says, "The best three things about teaching are June, July, and August." That's, you know, I politely try to get that interview closed as soon as possible. Now, at the same time, I'm more worried during the school year to give my teachers plenty of breaks because, in fact next week, next year we're thinking about going to a four day week with Wednesday being a day of remediation and teacher preparation. We expect our pastors to work all week on a sermon for forty-five minutes but we expect teachers to come up with 20-30 hours of teaching with over with weekend and at nights. And, our teachers have to get used to working during the summer, they work a lighter schedule you know, but they actually like it in the end. They're like, "Wow, I'm much more prepared." They like what they're doing so, you know, I'm like, "What else would you be doing during the summer? Painting houses? I mean don't you wanna be with the staff in here preparing and things like that?" So I want the teacher to be intellectually curious. I want them to feel called. I want them to be excellent. I make them teach me for an hour. Me and a couple of the other interviews for an hour and do an class because I'm bored very easily and if they bore me the first, in their best lesson, then they can't stay. And they need to be transparent. I'm really a lot better with broken people then people who don't know any better.

GP: Mm hmm. Very good. [Clears throat] Can you tell me, Bob, about a time that you felt most positive about your work and a time in the same token when your goals and values in Christian education were being met?

BG: I'd say one, one of the most, one of the most fulfilling times in, in Grace Prep was, I had a girl who, I kind of suspected of being a lesbian when she came in and she was a drug user and we have a three day kind of camp the first three days called "Extreme Grace" and I found out later in, about a month later that she had smoked marijuana on the trip. And so I brought her in and you know, she confessed to it. And I thought well we're gonna have a little bit of an issue here but uh, so, my thing with her was, first of all, what, should I have been surprised by that? Like it doesn't surprise that a person that came in that 
struggled with drugs would use them again sometime? I mean, that wasn't a surprise to me. I'm not surprised when people sin and so my deal with her was, "You will take," you know, like, I brought the parent in and said, "Okay, here's the deal, I'm, I want to help her stop this, this, this destructive activity so it's better with her being here with me in our school than anywhere else cause remember everything is relational, it's all about the one sheep. So, unless it's just disastrous on the rest of the school, I need to feed that one sheep. Um, so I said to her, "This is pretty simple. I want her to stay here, you know, but I'm gonna buy a bunch of man-, you're gonna buy a bunch of drug tests for me and if at any time I wanna bring her in, I'm gonna drug test her. And you're gonna pay for it because I'm not gonna pay for it. It's not, you know, my thing, so the parent was okay with that. Now, what were the options? People said, "Oh, how could you make them do that?" Well the other option was for the parent to say, "No, I'm won't pay for that. I won't let you do that." At which point I would have said, "Ok, well she can't stay because if you don't want to know whether she's on drugs or not, then what can I do for you?" But, I mean I had to explain it because i knew it'd get out to the community because it was already you know this is a very anti-Christian school. Well, I shouldn't say that. I had a pastor say he's very ambivalent about Christian education because almost two thirds of the people that live in State College work for the University or the school district. So, you know, you're kind of going right in the face of that. So what I did was, I wrote a letter to the parents and I said, "Here's the deal, we had an issue with drugs. We knew this would come up eventually and here it is and if you, you might hear this in the community. And if somebody says to you, 'Oh i heard there was a drug problem.' and they start complaining to you or running down Grace Prep, I want you to lean forward to them and look them in the eye and say, 'Excuse me, can I remove that huge log from your eye because we all have junk?" And when I, when I asked the student about it and I said, "What do you think Shawn about, you know, what do we, what do we, how do you think about this if we get tagged with, you know, where a bunch of drug, you know, where our kids are using drugs?" And he just looked at me and he said, "Bob isn't that what we're here for?" And I thought that was an unbelievable moment that our kids would get that. That that's what we're really there for. That was a great moment for me and we went through that process without a hitch. And no parent complained, nothing, they totally got it and I'll tell you why; because when you talk to them about the pregnancy thing, I always talk to them in the initial interview, "Look mom and dad, if you have a problem with like a girl getting pregnant and being here, you shouldn't be here cause you know what, if could easily be your kid or my kid." So, they love that. They absolutely love that concept, they get it and they realize how, how the paradigm of Christian education has never gotten that.

GP: Mm hmm.

BG: Certified teachers, you know, people say, "Are all your teachers certified?" I say, "No, they never will be because our teachers, a bunch of them almost all of them have Master's degrees but not teaching degrees." I believe as a Christian that teaching is a gift. Dannah has sold a million books, thirty-eight hundred books. She's about the national authority on sexual issues and teenagers, she couldn't teach health at a public school. Bill Gates couldn't teach, um, high school computers and Barack Obama couldn't teach uh, a class on the American presidency in a middle school.

GP: [Light chuckle and throat clear] 
BG: That's absurd!

GP: Mm hmm.

BG: So, that's kind of how I feel about that. So I take a lot of the things that people traditionally say to me that would be negatives and I'd be like, "You know, I think we have a real positive aspect of that."

GP: That's great. Bob, are there specific situations, people that have shaped the way you view education if you could boil them into a few and the way you relate with students and parents?

BG: Well, I had, I hired a principal named Pat Sullivan who would be great for you to talk to who loves God, brilliant, he's finishing up his PhD, and he was campus teacher of the year, a great guy. And he's, he's, I'm able to talk with him about the back and forth interplay between when a kid needs to suck it up and do his homework and when a kid needs some grace because that the hardest thing he can do, is hand his homework in on time. So we go back and forth a lot of that, with that, I talk to the teachers a lot about that. I would say there's a book that I read called, "Redemptive Teaching" [corrects book title] "Teaching Redemptively."

GP: Mm hmm.

BG: Which is very powerful and questions, you know what we're trying to do right now is questions the way we, we grade things. I came out from a perspective where my kids were straight $A$ students so their report card meant almost nothing to me; it gave me almost no evaluation of them. "Oh they continue to do well, they're smart and they're good students, they had all A's." I looked at it for 10 seconds and said, "This is fantastic." I, I believe we're gonna go back to an elementary school report card where you know in my report card I always got really good grades except for check minuses in handwriting and selfcontrol and discipline. I never could get that self-control and discipline check plus. But it said in there, you know, it would say in our new report cards, "Tries, has made improvement in his effort. Hands in homework on time. Is respectful in class. Participates in classroom discussion. Is a leader in the class. Exemplifies Christian values. Is honest and trustworthy. Gets to class on time." All these characteristics that we're trying to build into students that we don't evaluate, we only evaluate how they respond on a written test and isn't that odd? Like, I'm embarrassed that I don't have, haven't changed this already. Like, you know, we don't really give our parents a lot of written information about the character qualities of their kid.

GP: Hmm.

BG: It seems ridiculous to me now that I'm talking about it.

GP: I do. I do. Actually I worked in more of a preparatory type school in Atlanta and we were expected to write comments of about three quarters to a full page on every student three times a year so...

BG: See, that's fantastic. A lot of work too.

GP: It was. 
BG: Teachers don't, I find that teachers don't like homework.

GP: [chuckles] Huh, they don't.

BG: [Laughs]

GP: They don't. Yeah, I'm learning that quickly as a principal, it's interesting. Yeah, sometimes teachers are the worst students you can have.

BG: Right, right. Like, after they read a book and, of course it's cause they're in the grind, ya know, during the summers I can get, I can do a little bit more of that but that's still fairly unsuccessful for me.

GP: Yup. Well if I could ask you this, how could your methods, those that you've been talking about, for adapting the needs of the 21st century Christian school be brought to minds and methodologies of current Christian school educators like myself? How, you know, how would you bring them out into the world so that we could pick them up and run with them?

BG: Well, I think the forty points of grace and I didn't tell you the story but I woke up one night at three o'clock in the morning and I wrote all forty points of grace, and I wrote an e-mail to my friend saying, "If I started a school this is what I'd believe." And I wrote all forty of those points as they were, basically as they are in two hours and went to bed and e-mailed them and they haven't really changed, they're all the same. I wish I could have changed them as of now but you know, there's way too many of them that people think, you know, "There's no homework." which is not what it says but certainly it's pretty close to it. You know, the response that was unbelievable and those forty points now are, you know, life size on the school and they, people walk by them every day and that's, that defines the culture of our school. I believe that [pause] you know; one of the things we've really thought about is how I got into this to duplicate a model. And I find it very difficult because of the nature of leadership in Christian school and how differently it needs to think. And, I actually believe that rather then send my teachers to a, uh educators conference my first priority when I can afford it is to send them to a youth specialty, youth, youth pastor's conference. They're gonna get ten hours on cutting and eating disorders and relating to students because, in youth, youth pastors are much more aligned to relating to students on a spiritual level and teachers tend to be the exact, they tend to be so focused on reaching them at an academic level. So, how could I duplicate it? Um, I think a mega church, that somebody with a lot of, a lot of, a lot of platform like Focus on the Family could develop a school curriculum that was contemporary and that there be revolution in Christian schools 'cause that's, what, what would get churches on board.

GP: Mm hmm.

BG: Is if one of their popular people that they've followed, like Bill Hybles or Rick Warren would, would really show an interest in that. Because most of them just follow the leader but in general I think that it'd be great if there was a team of people of contemporary educators that were from different backgrounds that could put together some resources on evaluation techniques, of course I guess all of this has been done before. Ya know, I mean, I, I guess it's all been done before. I mean I'm not in the 
education field that long to know much better but um, I think that they need their basic principles challenged and they need to bring people in [exhales sharply] who think differently than teachers which that's kind of gobbildy gook 'cause most schools have boards but...

GP: Mm hmm.

BG: ....but you know I find boards to be very, very rarely successful at Biblical...

GP: Mm hmm.

BG: I have a board that's good for me and they're close friends since I, I kind of own the school and so the debt is in my name, I take a lot more control over it but it's an, incredible to me that boards meet on student issues and curriculum issues and issues of the school and the staff isn't there. It's just ridiculous, I have this fantastic staff of godly, that's around students everyday so I don't really see the, it's kind of odd for me to go take it to a board that's not there and they make the decision that seems very strange to me but it takes a leadership style that's very consensus building and recognizes that, uh, I've hired people that have very different traits but that are all very passionate, I guess it all sounds pretty cliché but...

GP: No, it's good. Very good. What role do you see parents needing to play in the 21st century Christian school?

BG: Well, I think parents should play every role they can. I think that you know they need to be more engaged in the school but you know what Gabe it's all talk because they're not generally going to be engaged so my staff gets frustrated about the lack of parent volunteers, I get frustrated about the lack of parent volunteers. But you know what? That's the nature of it. I know there's studies showing that when a parent pays tuition he feels like that's a service and he shouldn't have to volunteer as much. Of course they should be, you know, we have online grading because they can never say they don't know their grades. Of course they should be more involved but the reality is that that's, maybe I'm too cynical on this but, uh, I'll tell ya what. People should probably, I could, Gabe, I'm, I, this is very probably [exhales sharply] uh, this is probably very uh, controversial, I know it is, but I consider this, our school a church and I'm thinking about changing it into the classification of a church. I ask people all the time, "What is a church?" So I would ask you, "What is a church? What is a church about?"

GP: Mm hmm.

BG: And people might say, "Well, it has services and teaches people..." and I say, "Well, people would look at us as a church if we just didn't educate their kids. We have chapel twice a week, we have more activities and services then any church does, we give more away to the poor because we're giving scholarships to people that are in their churches and we're giving mostly to church more scholarships than they're spending in their benevolence fund." So over the course of seven years, in a big church in town, I've taken like five of their kids, or four of their kids every year, that kids cost me about $\$ 30,000$ over four years. I've had fifteen of them. I've given that church $\$ 450,000$ dollars, it's their benevolence 
fund. So to me we act like a church, we have discipline like a church and the only reason we don't look like a church is because we don't get a tenth of people's income and we don't um, and we have too many, too much, we have too much education going on.

GP: Mm, mm hmm.

BG: If that makes sense.

GP: Mm hmm.

BG: So, my thing has always been um, a couple things in my little elevator speech, one is it's much more practical for a church, for a school to start a church then it is for a church to start a school. A school already has an income base, needs projectors, needs chalkboards, all of, a sanctuary, all the things that a church needs but it uses all day long. Okay? So it's much more practical for me to start a church now. I have a community of believers and families and unbelievers that I'm, you know, I'm investing in their kids. I have an automatic youth group kind of thing. That makes sense to me and maybe I'm the only one in history that thinks that but it just makes total sense to me since we struggle, we have no building. I spent all my money on the teachers so our teacher's make, if a teacher can't make forty or fifty thousand dollars a year as the head of their family, I think it's very difficult for them to deal with things.

GP: Mm hmm.

BG: So our teachers probably make about twice as much as the average Christian school teacher because after four or five years, I want them making $\$ 50,000$ dollars a year which is why we have a balance of men and women and I have a pathetic building, I mean I share a building with a ballet studio which is one of our core beliefs is that we will always share a building.

GP: Mm hmm.

BG: So I could easily have a building if I just ripped, ripped $40 \%$ of the teachers' salaries away, give them $\$ 30,000$ dollars and spend $\$ 100,000$ dollars on rent, $\$ 100,000$ more. My other thing is, it's all about the teachers, you know, I'm a business man. I knew from the beginning that my theory was higher the best teachers, they're $98 \%$ of the interaction with students. Okay? And, if you line ten teachers up, okay? And you had a good teacher and a bad teacher, you know and it went all the way up the continuum, if you take that bad teacher and you give them a new classroom, all new computers, and all the budget he wants he will still be a stink pot teacher. If you take the best teacher of the ten that's fantastic and you take away his classroom, and you give the kids, you know um, they can sit on the floor and give them an old chalkboard, he's still gonna be the best teacher there... it's a gift. And, schools have to fire their bad teachers. And, and one of the most important things I can say is it is an ethical violation to have a bad or mediocre teacher in a classroom.

GP: Mm hmm. 
BG: And I find that teachers respond curiously to that but as a businessman I'm not, this isn't the business for me, this is, I'm putting your kid in a history class or particularly in middle school or in elementary school where they have one teacher all day, to have a mediocre teacher is a total ethical violation, I mean it's just, I mean, what you're representing is what's good for that kid and what you're providing is, is terrible. And we allow mediocre teachers because we don't want to face the confrontation of them. If, if your school cafeteria lady burnt all the lunches or half the lunches every day you would get rid of her but if a teacher does the same thing, you know, it's a confrontation that people don't want to have, so...those are all my little, you know, fifty cent pitches, i guess you know, you can take whatever is good and leave the rest. I would say we've been very successful and having major transformation of my students, producing kids that um, are good academically and kids that we've brought up that were circling the drain and we've rescued and you know what, at the same time, you know, I talked to a kid last night that went to my retreats, read my books, went to three years of Grace Prep and is having sex with his girlfriend. I'm like, "Wow, darn. You know? What's the disconnect there?" Well maybe the same disconnect I had when I was a kid. So, that's frustrating but I have a very long term view. My view of how we do, is how we do twenty years from now not, not now. It has very little effect on what I see a kid doing in the next five years, it's um, it's how they're doing fifteen years from now.

GP: That's very good.

BG: So I don't take much of the credit if they do well right now and I don't take much of the blame if they don't.

GP: Mm hmm. That's a good philosophy. [Deep breath, throat clear] Are there any, you've mentioned a couple of books, are there any other books or reading materials that you would direct me toward that have inspired you recently or in the past?

BG: Well, I'm gonna think of more after I get off the phone but one of the things I had my teachers read of course from a business background is, "Raving Fans" um by Ken Blanchard. It's a little parable of how to serve parents and serve clients in that book. And I call my parents when they come in; I call them clients when they enroll. Like, "You're a client. You can come in here and yell at me behind closed doors." That's one of our points of grace. "You should not hold things in, if we do something wrong you must come to me, or why, why are you paying tuition?" Parents love that. Like, you're paying, I tell parents, "Tuition next year is $\$ 7900$ dollars, okay?" Which in another story, I got frustrated our tuition wasn't high enough so I told the parents, "We're gonna, we're gonna, we're gonna vote on tuition rate live. You're gonna, you're gonna pick your own tuition increase from 0-500 dollars and I went through the whole budget and how the insurance increases and what the teachers made and at the end of the night we have twenty-five parents there and twenty, twenty-two of them voted for three hundred dollar- or I think fourteen, three of them voted for $\$ 300$ dollars, fifteen voted for $\$ 500$, and five of them voted for more than $\$ 500$ dollars. [Chuckles] SO I was able to, you know, that's just through transparency.

GP: Mm hmm. 
BG: But they like when I say, "I have to provide $\$ 7900$ dollars of value to you, extra value that you can't get from the public school for free so that's how hard I have to work." And Christian schools have to stop thinking that they're value, that $\$ 7900$, they're tuition value is because they teach the bible. That, they have to teach that and add more value than that because um, that's what parents deserve and it can be done.

GP: Hmm.

BG: Man if I had a little bit of help from churches, a little bit of help from a big donor, or a few small donors, oh the places we could go. But, uh, "Raving Fans" by Ken Blanchard's one of those books, the "Redemptive Teaching" book, [thinking] uh, and I'll you what book is my favorite book, Philip Yancey's, "The Jesus I Never Knew" because if I had to describe what i want out of education, it'd be how he teaches about Jesus in that book is how I want Grace Prep, is how different I want Grace Prep to teach because, you know, he changed my view of the Pharisees. You know, at one point, you know, he gives a story about how, on a trip into Jerusalem there were 400 Pharisees crucified along the road. So these weren't these big evil people with, you know, black robes, they were, they were pastors. I think that's probably the Biblical translation it should be, I think the Pharisees translates into Spiritual Leaders and those are pastors. So [Chuckles] I don't think I can, you know get to, you know too popular doing that except for that I think the Pharisees were generally pretty committed guys. What I'm saying is the way Phillip Yancey describes Christ in that book and how he looked differently, how he acted differently, he wasn't six foot two and great looking is the way I want kids to see a different prism and perspective of everything we teach them.

GP: Mm hmm.

BG: Now it's not usually just black and white. One of the things I do, Gabe, that I think is really neat when I teach my class is two of the things I did, one is the first test was on liberals and conservatives and I gave five, you know, general characteristics of a liberal: pro-abortion, pro-Obama and then five characteristics of a conservative. I said, "I want you to know these, you have to know these. It's very important to the class. I want you to know all these. So you get an A or an F. You either get them all right or you get an F. There's only ten of them, just learn them and you'll be fine. Here's the exact question." I also believe in giving kids much of the questions on the test, I don't believe in having them study a chapter with thirty pages and making them learn all thirty pages when only about five of the pages are important.

GP: Mm hmm.

BG: We teach kids fifteen different, you know the average school teaches kids fif-, probably mine does right now too, fifteen different generals of the Civil War and really there's about two of them that you really need to know.

GP: Mm hmm. 
BG: And if you teach them fifteen they might forget the two you really wanna know because they're only gonna retain about $40 \%$ of what you, what they learn. So why not teach the two or three they really need to know and cut out the lot of the rest of the curriculum that they just, that is just, passed down from generation to generation. I want the kids to um, nail the SAT and, and have a proper perspective of life. Oh what I do in the class, well, when I did that A and F test, every kid in the class got an A except for one, who just couldn't do it, one girl and I said, "Well let's do it again." and she couldn't do it. I said, "Well draw me pictures." And she drew me pictures and I was convinced that she knew the material even if she couldn't test well on it and that's what my job was. The rest of the class a lot of it is, I will pick, I will pick, because one of our points of grace is having an intelligent faith which I think is so lacking in a lot of Christian schools...

GP: Mm hmm.

BG: I pick ten or twelve topics, I do not believe have a Christian world-view, which I've tried most Christian's begin with but I don't necessarily that taxes have a Christian world-view. You know, we generally think that Christians, we won't ever decrease taxes to what level what percentage points? I'm not sure that Arctic drilling has a Christian world-view, although most Christians are just, "You gotta drill, drill, drill." I don't think that um, I think you can come at; you know the death sentence from two completely different world views and be a Christian on both sides. So I pick, I pick eight or ten topics to challenge them and say, "I want you to take the opposite. I want you to convince, I want you to confuse people in here to where they say, 'Wow, that's, I probably shouldn't go to, go to war on my biblical stance on that when there are great and godly people on both sides." That's one of the things I want the kids to learn and they find that very challenging. And that's why, why I want them to think through and not, not get so pigeon holed into one, one, what the Bible would call meaningless, foolish arguments.

GP: Mm hmm. [Clears throat]

BG: Which somebody told me the other day was basically, job security for seminary professors.

GP: [Chuckles] Ha-ha. Yeah, maybe Bible teachers at the high school level too.

BG: That's right, that's right.

GP: I can say it. Well, I've asked you quite a few questions and you've been very gracious to answer and give me your insights from your knowledge and perspective there at Grace Prep and that sounds like a really unique school so I do hope sometime to maybe take the time to come up and visit.

BG: Sure.

GP: And see what it's about. And so, thank you. I really do appreciate... 
Title: Phone interview with D. Bruce Lockerbie

Date/Time Recorded: 3/29/2011 2:02:51 PM

Record time: 1:13:34

GP: Alright well I'm talking with D. Bruce Lockerbie here and interviewing you again Bruce on the Christian Education for the 21st century. It's my thesis project and you're actually my first interviewee.

BL: Let me, let me quibble with you.

GP: Sure.

BL: You're actually talking about Christian schooling.

GP: Yes, thank you. I knew you were gonna bring up that point.

BL: Christian education is the big tent. It's Sunday school, its youth group, its bereavement counseling, its pre-marriage counseling, its divorce reconciliation, its neighborhood bible study, and so forth. But Lititz Christian School is very different from all of those.

GP: Very good.

BL: Number one, you charge tuition. Number two, you provide parents in the commonwealth of Pennsylvania with the legal means of fulfilling their obligation to the state. Friday night youth ministry doesn't do that. So, I think it's an important distinction and I'm trying, I'm trying, none too subtly to influence everyone in this calling to refer to it as Christian schooling not Christian education which is too general, too vague, and not what we do.

GP: Perfect, well thank you for those comments, and actually I was hoping that you would say something along that line.

BL: Good. We got that off our chests, right?

GP: You're actually gonna hear in my questions you know kind of a leaning to what you were just talking about and so you can see, and you're already aware of that conflict that exists in, uh, Christian Schooling and Christian education, the terminology. Okay, so, I'll use Christian schooling which is listed on my question number one here. What are the key elements, Bruce, that you believe should set Christian schooling apart from secular schooling, especially in the 21st century?

BL: Well, let's begin by asserting, without being repetitive, let's begin by asserting that our particular calling is different from other elements of Christian education in that we are called to be a school. We are not called just to have pleasant relationships. We are not called just to sponsor a football team. We are not called to protect a generation from the sins of the flesh. We are called to educate and some of 
us have been doing that all along and some of us have not. And those of us who have not have given a dreadful reputation or ineptitude or uh, academic inferiority and indeed, or a kind of pias antiintellectualism. And Christian schools that intend to be schools need to disassociate themselves from those that don't.

GP: And how...

BL: So that's, that's the starting point. We gotta know who we are and what it is we are called to do. Now none of that, none of what I've just said, uh, need diminish our fervor for Jesus Christ. You, you, uh, I don't know if you've ever been in an audience when I've spoken but one of the things I've said in Lancaster on at least two different occasions that I can remember is that I am weary of hearing people say, "We want to be a strong school but," always the "but", "We want to be a strong school but we don't want to lose our fervor for Jesus." And of course the assumption is that the one must uh, follow the other. And so I'm waiting to hear somebody, you, others, say, "We want to school because we don't want to lose our fervor for Jesus."

GP: Hmmm.

BL: But the easiest thing in the world is to be, wet-noodle pious and sanctified and sing all kinds of mellow songs about Jesus. The hard thing, the hard thing, is to teach calculus for the glory of Jesus Christ. The hard thing is to teach AP Latin for the glory of Jesus Christ. And far, far too many of our schools are content to be sanctimoniously mediocre. So that's, that's part and parcel of number one and number two. And then I would sort of fall into line and say that the next most important ingredient is that the adults be committed believers, called to the work or the support of, Christian schooling. Frank Gaebeline said that, the "sine qui non", the, "without which nothing" of Christian schooling is no Christian schooling without Christian teachers. Well our, our colleagues in the church related schools, let's say, in the Episcopal schools for the most part, in some Lutheran schools, in some church related schools, have thrown that aside especially when it's inconvenient, difficult to find a believing physics teacher. Well, we bring in somebody who can teach the course, after all, it's not as if you were teaching the Bible is it? It's just teaching physics.

GP: Hmmm.

BL: So, I guess we can get away with that there and whatever ungodly coach, because after all you know, he's only coaching basketball, it's not as though he's doing the apostle's creed and little by little the, or we bring onto the board someone with local influence and maybe some money who has an interest in non-public schooling but not necessary in Jesus Christ. We bring on that board member who has a friend that he brings on and little by little the commitment of the board erodes. So that's an absolute. And then the fourth part is that we need, most of our schools that have identified themselves with either the reformed language of covenantal, that is to say "kingdom kids", boys and girls whose families are believers or those that now call themselves, discipleship academies, where, this is not meant to be amusing, where it's quite often the case that a rising middle school student has got to fill out a questionnaire about what he believes and the rising secondary student has to have an interview in 
which it gives a date and time of conversion before he can be admitted. I think that's long past time for us to reinterpret the wedding guest parable because like the guests who were originally invited to the feast, most evangelical families have turned us down. The late Ken Gangle from Dallas Seminary estimated that $80 \%$ of evangelical families have never considered enrolling a child in a Christian school...

GP: [Soft Chuckle]

BL: ....whether it's that number or some other I, I can testify that if I'm serving a church sponsored school and I show up on Sunday morning or show up and take a look in the sanctuary, I'll see the numbers for Sunday school attendance and if it's a sizeable congregation there you know, two hundred or four hundred or whatever number of people present and I'll ask, "How many of those are school-aged?" "Oh, you know two hundred fifty." Great, so then on Monday morning I show up for the school and I ask, "How many of those who were here yesterday for Sunday school are here this morning for the day school?" Well if there were two hundred fifty the day before, I won't' find twenty five today...

GP: Hmmm.

BL: ...or if I do it's rather unusual. There will be a sizeable number of children in the school and they will be from fifty, sixty, eighty, a hundred different other churches but the sponsoring church won't be able to turn up twenty percent of the student body. So, if the evangelical families have already turned us down, why are we insisting that only they and their children are welcome in our schools? Why aren't we doing what the parable teaches? Why aren't we going out into the highway and the hedges where the hungry are, where the needy are, where those who want what our school has to offer but have never been welcomed to enroll?

GP: That's a very good point. That's a very good point. Well there are definitely a few things I could comment on personally within your answer to question one. I'll just comment briefly here for the sake of maybe my own notes and just your knowledge of me as we're talking. I came out of public schooling myself and was searching for Christian schooling after being a teacher for two years in the public sector and landed in a school that had been formerly Christian and was actually head mastered by the son of your mentor, Frank Gaebeline, called the Westminster Schools.

BL: Sure.

GP: And by the time I had arrived at Westminster they were certainly open to the fact that I was a Christian and were happy about the fact that I would prefer from time to time to certainly share scripture and pray with my students. Not knowing what Christian schooling really was at that time, I went into that environment thinking it was, you know, the, the apex of what could be done in education because of their excellence in other areas.

BL: Absolutely, yeah. 
GP: And I certainly found very quickly that I was labeled as a fundamentalist and a bit of a weirdo when it came to the fact that I wanted to pray with my students before tests and, at other times, specifically quote the Bible to English's classes I taught.

BL: The man who actually succeeded Donn Gaebeline announced on his first day, on meeting with the faculty, he said, "I know the tradition and the history of this school. As far as I'm concerned, prayer is appropriate at home and in church but not on this campus."

GP: Hmmm.

BL: That was Bill Clarkson. An Episcopal priest as a matter of fact.

GP: Yes.

$\mathrm{BL}$ : And, as a direct consequence of the apostasy at Westminster, there is now a school across the Chattahoochee in Mableton called Whitfield Academy.

GP: Mm hmm.

BL: Several of the Westminster teachers and sub administrators moved on over there, let me see if you know some names.

GP: I went with a group that was headed by Zach Young.

BL: Oh, yea, sure at Wesleyan.

GP: To Wesleyan School. So that's where I landed only a year after going to Westminster.

BL: Yeah. Yeah. Well you had two very good experiences in Atlanta so far as your resume is concerned.

GP: Yes, sir. I was very fortunate. God led me along and then, that made quite an impact on me.

BL: How long were you with Zach?

GP: I was there for four years, and then we ended up on the mission field in Romania through a mission's trip.

BL: Was Brian Kennerly there?

GP: Yes, he brought me on as an English teacher and a wrestling coach.

BL: Yeah. Good.

GP: So.

BL: Where did you worship in the area?

GP: I worshipped at Perimeter Church. 
BL: One of my, one of my favorite alumni is pastor of First Presbyterian down on Peachtree and 16th Street.

GP: Okay.

BL: Old church in town. And, a real tribute trophy of God's grace. He was a real foul mouthed preachers' kid at Stony Brook.

GP: Hmmm.

BL: And frequently missing his next sports event because he was on suspension of some sort or other. He became a believer in his senior year in University, went to seminary and is pastor of some very strong churches.

GP: That's great.

BL: That's highly interesting. I mean, you have been, literally, you have been, to the acknowledged leading independent day school in America, without question. And, and, and tragically a place of, the founding, the founding of Westminster by North Avenue Presbyterian Church in 1950 was directly the result of William Presley's desire to have a day-school like Stony Brook.

GP: Mm hmm.

BL: And Frank Gaebeline was his personal advisor in founding the school.

GP: Wow.

BL: And, and Donn served initially as a young teacher and then principal of the boy's school, and then after thirteen years at Stony Brook, returned as president.

GP: Hmmm.

BL: But he was barely out of office before the board determined that they would in fact invite nonbelievers to be on the board.

GP: Wow.

BL: And the leader of that was the publisher of the Atlanta Journal and Constitution...

GP: Hmm.

BL: ...who insisted that Westminster could not turn its back on Atlanta's Jewish population.

GP: Wow. By God's grace I've had the opportunity to see quite a few things so I'm excited to certainly learn more from you and, you know, it's interesting how our roots tie together in some ways there.

BL: Yeah, yeah. 
GP: Well I wanna keep asking you some of these questions here, the second one is: What specific needs of students in this particular generation stand out to you as unique or even different from past generations?

BL: Well I think it's no secret that [pause] the concentration, focus, singularity has eroded and it's been it's been eroded since, uh, the electric company and Sesame Street.

GP: [soft chuckle]

BL: What do we have? We have a four minute concentration span? Fox News channel will sometimes stretch to five minutes on a particular topic. The, the kids are not immune from this disease and, it's, it's far harder I, I observe as I've just finished visiting sixteen classes at a particular school I'm serving. It's far harder to hold the attention of a class and indeed harder if all of us have our text book or novel or workbook open to the same page, it's far harder if that page isn't also projected from the PowerPoint [pause] gadget onto a screen and the teacher is up there doing something with a pointer or a laser and highlighting and smart boarding and so forth, and so on. The technology can be an antidote but in, in much in the same way that the drugs we take are sometimes as bad as the disease...

GP: Hmm.

BL: ...so the technology is sometimes as distracting as is the absence of technology and the squirming and distractedness of the class. [Pause]

GP: Are there two or three necessary changes you believe teachers must make to reach these students in the 21st century?

BL: It would start with perhaps, and never is almost too strong a word, but almost never sitting down in the classroom. A teacher who is seated behind the desk does not command the same attentiveness and cannot approximate the same nearness, physical nearness, proximity that is spoken of when someone speaks about... The best school I ever attended was my teacher on one end of the log and me on the other.

\section{GP: [thoughtful chuckle]}

$\mathrm{BL}$ : There is a, there's something that happens when a teacher is walking the aisles or, or leaning over a desk and paying personal attention to the student and quizzing that student not quite face to face but almost, a lot of difference between that and the, remoteness of the front of the classroom and the desks separating us. That would be number one. Number two would be some animation, some, some excitement, some intellectual curiosity on the teacher's part, some intonation, some change of volume, some, what speech pathologists refer to as stress pitch and juncture, some tonality. Even if necessary, some lectern pounding, something that expresses passion. To me there's a simple rule, when I have lost interest in my subject matter, I have lost the moral authority to teach.

GP: Mm hmm. 
BL: And, and you know if it's old ham and leftover potatoes and cold soup to me, look, how can it possibly be to the kid who didn't care when, when he walked in the classroom to begin with? So, we need some uh, dramatics, some theatrics, some people who, who really do care about communicating the significance, the essential nature of whatever our content is. But here, here's something that, this may anticipate a later question, but here's something, if I were to return to the classroom on a regular basis, if you were to offer me a position, I would make you this promise; I will start every class with a question. I will never start the class by putting the outline on the screen or passing out a handout that states what the purpose of this class is and where we are going to end up forty-five, fifty minutes from now. I would ask a question. And one of the questions I would ask especially, we're talking secondary now, or, or even middle school, the bell rings and my classroom empties and sometime in the next five minutes, it refills but it refills from six other classrooms and as those students come in, we adults demand of them, unspoken demand, we demand of them that they irradiate everything that's in their minds from the previous hour and everything they might have been thinking about in the five minutes of moving from room to room...

GP: Hmm. [soft and thoughtful]

BL: ...and that they begin to think only and exclusively about my subject. Now frankly, most adults would have trouble doing that ourselves. We, we would, we would be conversing about something or someone or someone's clothes or what someone said or someone's body odor. We'd be we'd be making reference to our immediate past experience. The typical secondary, middle school teacher doesn't take that into account. I mean, I cannot tell you the last time I heard a teacher say, "What were you learning in the last hour? Where have you been? Spanish? History? Bible? Math? Oh, what were you just discussing in math?" And the really expert teacher, the innovative imaginative teacher from time to time finding something that ties to what she intends to be teaching in this class and saying, "Oh, that's interesting. About ten minutes from now, I want you to tell me if you see any connection between what was going on in geometry and what we are going to be talking about." And then start with a question. IN my, my, my sense of what is the uniqueness of the pedagogy of Jesus of Nazareth is that he gave a few rules, he told a few stories, and he asked hundreds of questions.

GP: I like that, that's a great way to put it. Do you see, Bruce, any technological needs that are essential to be taught to our students, those things that are most, in your mind, a confidence that are needed for student's in Christian schooling moving forward?

BL: Well, I too had a public education and I'm fond of saying, I'm not ashamed to say, the single most important class I ever took was one semester in 10th grade of typing.

GP: Amen, I did the same. [Laughing]

BL: That's how I make a living today. And, and so keyboarding, if that's what it's called... GP: Mm hmm. 
BL: ...is absolutely essential, not perhaps so much, not so much expert computer programming skills. That may or may not be that is now in fact an advanced placement subject. But knowing to do it with, with accuracy is certainly important. And then, we would go from, from that into all the different aspects, elements, but it seems to me, increasingly true as I've, I've walked through Christian schools quarters or as I've said recently visiting sixteen classes, there's very little instruction that the school needs to give. Kids are on their iPhones without having sat in one of our classes. They have mastered much of the basics of 21st century technology on their own, but what we need to do is, is to help rid them of debilitating addiction to the social networks and warn them about the dangers that are uh, explicit and, and, and frequently in the headlines day after day after day. The folly, the absolute life threatening folly of "hooking up" on the internet and everything else that goes along with that.

GP: Do you think there are key issues right now dividing students and their teachers as you look at 21st century Christian schools?

BL: Oh sure. Oh sure. I mean, that's, some of the people I observed in the last couple of weeks barely knew how to find the wall outlet, you know, and barely knew how to put the cord in the wall never mind, never mind having bothered having to master whatever the device was that they were accountable for using. I mean, I can remember, when, when overhead projectors were introduced and I remember distinctly a manufacturer's representative coming to a faculty meeting to introduce us to some of the tricks and, and strategies for making use of this invention. And the first, the first acetate you put on the machine had six or seven misspelled words on it, you know. Well that wrote the whole thing off for some of my colleagues, they discounted the purchase or the value of the gadget, simply because the guy promoting it couldn't spell. There are, there are still some members of our faculty who, who are luddites when, when it comes to such simple things as email. And, and I know schools that have been riven by controversy and dissention because the administration has gone to Renweb or Edtech or whatever and, and, and now make available to parents on a daily basis today's quiz scores or today's comments on an essay, and of course the, the old timers treasuring the privacy of their grade book and not wanting a constant stream of telephone calls from mama, resent the intrusion of technology upon their profession. Well- that's, that's a matter to be settled by the discretion and the wisdom of, of the head of the school I suppose, But it, it probably will result in some firings from people who simply choose not to modernize.

GP: Have you recently made any suggestions to people in the teaching profession as to how they might or adjust their teaching to reach modern students?

BL: [Laughing] well the school I've been visiting has moved from chalk boards to white boards, okay?

GP: Mm hmm. [Clears throat]

BL: And in about half of the sixteen classes I've just seen the pens, the markers, are either running out of fluid or are of a color not compatible with the white board and in particular if the sun is shining in the room and shining on the white board, washout. But the third thing is the illegibility, the scroll, and the tiniest of whatever it is the teacher is writing on the whiteboard. 
GP: Mm hmm.

BL: And I have said, without a great deal of tact and grace, I have said, "Is it not a given that if we write something in front of a class, the purpose is to communicate and the purpose is for the class to be able to read what it is we wrote. So might we not write with a darker pen, more legibly and larger?" I mean this, this is so simple. I recall sometime at the end of the 20th century somebody did a survey of technological improvements over the generations, over, over, in fact over the centuries, and the single most important improvement was deemed to be the invention, or the installation maybe, in the 1860's of the classroom chalkboard.

GP: Hmm.

$\mathrm{BL}$ : Whereas prior to that students might have had their own slate and the teacher might have had his own slate but now along comes the, I think it was some firm in Decal, Illinois as a matter of fact, that made available and popular the room wide chalkboard.

GP: Hmm.

BL: Well for what other purpose to communicate with every student in the class at the same time.

GP: Hmm. It's interesting because I have a new Spanish teacher this year and he had asked for a small set of whiteboard, a very small slate style set of whiteboards with markers and could be individually given to students during a class period and it's as if they want to go back to a time before the 1860 's...

BL: That's interesting. Yeah.

GP: And uh...

BL: What would be the use of it?

GP: Well, they do small assignments that can be placed on the whiteboards and then later erased; you know things that are...

BL: Yeah. [In background quietly agreeing]

GP: ...quick answers that everybody can kind of hide their answer on and then show.

BL: Yeah.

GP: And he can quickly check during the class period.

BL: Yeah, I guess that's got some merit. Are they available?

GP: They are. Mm hmm.

BL: Yeah. 
GP: So, yeah, it's just interesting to note that the history kind of repeats itself.

BL: Oh, sure. Well, that's of course one of the phenomena of American education not universal education that the pendulum swings loudly to the left and ten years later, to the right. And all of the virtues that we ascribed to, the leftward movement are cancelled and the whole generation of, you know if the generation is twelve years or thirteen years in schooling, it's uh, turned upside down.

GP: Well, we've talked a bit about some of the specifics that you feel are definitely necessary in Christian schooling, what specific steps must be taken quickly to bring about the sort of learning environment you see as most beneficial for today's student?

$\mathrm{BL}$ : Are we speaking specifically or primarily of the classroom environment?

GP: Um, I would say we could speak on the school at large and also maybe in the classroom, but maybe on the school at large first.

BL: Yeah. Well, let me philosophize for a moment.

GP: Sure.

BL: We owe our current sense of obligation to have an institutional mission. We owe this to the man named Peter Drucker who in the 1940's and 50's instilled in American industry the sense of mission which he borrowed from the military. And right now we are hearing numerous conversations about the fact that we don't know what the mission is in Libya because the military always knows what its mission is. Knowing your mission is half the battle. Well Drucker too that from commercial industrial business to the not for profit sector in perhaps the 1960's or so and from the not for profit sector, he took it to education. And one of the earliest was a college president in Memphis, south western college at Memphis now called Rhodes College named James Drawdill who latched onto Drucker and began posting the new mission statement for his college at every classroom making little stand up pyramids on the dining tables in the cafeteria of the school, posting the mission statement in every office, making sure it was on every publication and this set the trend. And Christian schools probably got around to following this maybe, I would guess, in the mid 1980's or so. So you began hearing about mission but now more recently, we're adding a second word and that's the word vision. And so, just as recently as this past year, 2010, I was in a school in the Dallas suburbs in a brand new auditorium being dedicated with an inscription on the rear wall of the auditorium so that $\mathrm{I}$, the speaker, could see it but nobody in the audience could see it because I was looking toward the rear and they were looking toward the front. And somebody in the audience said, "I'm confused about the terms mission and vision. Can you define them for me?" And I had given some thought to it but l'd never, I'd never explicitly been asked in a public gathering to make the distinction so I said, "Yes, I'll do it but you'll all have to turn around in your seat and look at the rear wall of this new auditorium." I said, "Here is the distinction in the text with which we're all familiar. Train up a child in the way he should go and when he is old he will not depart from it. The mission of the school is the day after day after day training, educating, instructing of the student. The vision is the hoped for, prayed for, anticipated result of fulfilling our mission." So then I got 
fancy and decided that I would speak in these terms. "Mission is our temporal academic purpose. Vision is our eternal spiritual purpose. But the temporal must precede, not exceed but precede; the temporal must precede the eternal. If we don't do our work well, if we do not provide the education that student deserves and the parents are paying for, if we don't have that as our immediate day by day priority, in other words if we don't bother to prepare for tomorrow's lessons, chances are that, that we will endanger the vision we hold for the eventual adult discipleship of our graduates." And then I go on to make that point because my wife and I are now old enough to be celebrating with alumni their 50th reunions.

GP: Hmm.

BL: This started for us in 2008 with the class of 58, 2009 with the class of 59, and last fall the class of 60. These are 68 year old grandfathers, most of whom have not seen each other since graduation day and in most cases, we have not seen them either. And the stories they have to tell are, uh, are both joyous and disappointing and a very peculiar thing happens at these 50th reunions, the teenage rebels and the teenage saints have sometimes exchanged places.

GP: Hmm.

BL: So, one, one of the things I think is rarely spoken of in Christian schooling is that we need an environment; we need to create an environment, an institutional environment which means person after person after person sharing the same intentions and same goals. We need to present and environment that is marked by realism and grace. Realism, recognizing that every one of them is like every one of us; Persons in need of transformation by the atoning work of Jesus Christ. They are no different; we are no different from each other. Number two, we need to exercise grace in recognizing that the unformed, unshaped, immature, pre-adolescent and young adult is, is who we're working with, and they're going to make mistakes, they're gonna blunder, they're gonna fail, they're going to disappoint just as if the truth were told, some of us will also.

GP: That's a compelling vision. So if...

BL: Well, it gets rid, it gets rid, Gabe, it gets rid of sanctimony.

GP: Mm hmm.

BL: I mean, I, I frankly gag; I gag over some of the language that marks the discourse of Christian school professionals. It's, uh, [chuckles] it, it needs a very strong dose of realism and grace.

GP: I like that. So if you're involved, and I know you have been, involved in a hiring process, what are the specific qualities or characteristics that you look for in applicants to provide students with this type of Christian schooling we've, you've been talking about.

BL: Yeah. Well I would always look, of course, much of my work was in the boarding environment but forgetting that for a moment, I would always look for a young person who has had either summer camp 
experience or has been an RA in undergraduate or graduate school and is, is familiar with the foivels of young people. I would look for someone who has what Frank Gaebeline used to call "presence" that is to say a personality that uh, wakes up a room when she walk in or when he walks into the room, that people are, there's a compelling aspect to the personality and kids are attracted to, and eventually want to emulate, want to be like such a person and that very often is measurable by one's own selfdeprecating humor.

GP: Hmm.

BL: Somebody who doesn't think of himself more highly than he ought to think but can laugh at himself. Um, [pause] I remember the absolute moment that a boy in the class of 1963 standing with me said, referring to one of my colleagues, "Why is it that the administration of this school cannot recognize in the first 10 seconds what everyone of us can recognize which is, this man will not command my respect?" I thought it was a penetrating question.

GP: Hmm. From the mouths of babes.

BL: Yeah.

GP: Can you tell me about a time that you felt most positive about your work and your goals, values, in Christian schooling being met, if there's one particular time that just stands out.

BL: They tend at this stage to be long after the fact and they tend to be the moment when an alumnus says, "You're not aware of this but..."

GP: Hmm. [Chuckle]

BL: Then tells a story. I, I, I can't, I can't say that there is any one moment that stands out that I, I, I had a carefully calculated strategy that I employed and it worked. I can say that there were moments of spontaneity. There's a, speaking of self-deprecating humor...

GP: [Chuckle]

BL: ... Here's an instance. In my very first year at Stony Brook living with forty 12 th graders, I was 22 , my wife was 21 . They were 17 and 18 . After the evening meal things just began to quiet down a little bit. The evening study period had begun and the guys were in their rooms, there was a loud pounding on our apartment door in the senior resident's hall. And when I opened the door a missionary kid, was panting with anxiety and I'll just make up names. "Mr. Lockerbie, Mr. Lockerbie, Smith and Jones are killing each other in their room!" Well I knew precisely which room it was and I pushed him aside and ran down the corridor and up the central staircase of the building and as I burst into their room I did so voice first and what I said was, "Okay you guys break it up." And as the door opened all the way, there on one of the beds sat the saintly Frank Gaebeline with his arm around the shoulder of one of the two guys. The other one was not in the room. The one around his shoulder, his arm was, was perhaps the most ardently rebellious member of the class, also the son of missionaries. And I came bursting into 
room with my announcement. Well I put on the brakes and I backed out of the room and then as I backed out of the room, my tormenter who had set me up was grinning at me from down the other end of the hall. He knew precisely what was going on and he had gulled me into making a fool of myself. Well at his 50th reunion, I told the story, both of these guys were present. I told the story of it, and the kid who was being prayed over told us publically what it was all about. He was planning to run off and marry a girl who had just announced to him that she was pregnant. Frank Gaebeline somehow or other got wind only of the fact that he was gonna run off he didn't know the rest of the story but he was there to pray with the kid and I was there to break it up. [Laughs]

GP: [Laughs with BL]

BL: I'm afraid there were far too many of those kinds of stories rather than the, you know, the glorious and triumphant. But there are enough of them to make me say to any young person in Christian schooling, "Don't quit too soon. Stay long enough for an alumni reunion, may not 50 years, but stay long enough for an alumni reunion and have somebody tell you, "You may not remember this but what you did changed my life."

GP: That's great. What were there any specific situations or events that have changed the way that you view Christian schooling or the way that you relate with students or would suggest relating with students, parents, colleagues?

BL: Well, let me talk about something we have not mentioned at all. We've not talked about money. GP: Mm hmm.

BL: You'll have to put this into your own frame of reference. I, I was hired, I was teaching at Wheaton College, teaching and coaching, I was hired for $\$ 2400$ dollars and room and board, meaning an apartment in that senior residence and meals in the school dining room.

GP: [thoughtful chuckle]

BL: As, this is 1957, as my wife and I arrived, I received a $\$ 100$ dollar increase giving me credit for my year at Wheaton so that's $\$ 2500$ paid over 10 months.

GP: Wow.

BL: And very little in what drawn in taxes and everything else we needed our telephone bill and no heat, no electricity, no garbage collection, none of those bills, no maintenance. So we did have to supply the fresh light bulbs, but other than that, and pay the phone bill. So the two of us, we had a child born soon thereafter but, the two of us are able to enjoy life with $\$ 245$ a month with all of our food and housing provided. So the next year is a $10 \%$ increase, so now I'm at $\$ 2750$ and the third year there's another $\$ 250$ increase, so now I'm at $\$ 3000$ and then the course of the summer, the headmaster was largely off campus but money came back in late August, he summoned me to the office and said, "Because of the 
generosity of a donor I am able to offer you a revised salary for next year." And to my utter astonishment, the revised salary was another thousand dollars.

GP: Hmm.

BL: So from $\$ 2500$ to $\$ 2700$ to the prospects of $\$ 3000$ became $\$ 4000$. [Long pause] That was quite a vote of confidence and while nothing thereafter ever approximated that kind of percentage, there was always a sense of the workman's worthy of his hire.

GP: Mm hmm.

BL: And, and I think far too often, far too often, we lose good people because frankly the board is too cowardly to set tuition that makes faculty salaries livable. And the opposite of that is that we obtain people who must of necessity rush from the school parking lot to their afterschool job at Burger King or wherever, where they stay until 9:00 and then return home and start preparation of tomorrow's lessons. And you cannot build excellence on that kind of personal calendar. But here's, uh, here's a different story. Well, I'll give you two. I think I've written about this in Christian Paideia. In the class of 1962 was a really awkward and disagreeable only child, son of older parents. Everything, everything you would choose not to associate with if you had your druthers, if you could pick and choose teenagers, you would not pick and choose this one.

GP: Hmm.

BL: Uh, early on in his ninth grade year, which was his first year, I was summoned to the office of the academic dean who said, "I want to talk with you about Roger. Roger is very unhappy and wants to leave school and Roger is not the sort of student that we should be dismissing. We need to do what we can to keep Roger. What are you prepared to do?" Well I was very bold. I said, "I am prepared to help him pack his suitcase and take him to the train. In fact, if need be, I'm prepared to drive him home. He is a nuisance in class and I'm not surprised that he's unhappy. He makes me unhappy." "Well," said my academic dean, "It's not just the class," He said, "It's the after school exercise group that you are in charge of that makes him particularly unhappy because he has no athletic skills at all and he thinks that this is a waste of his time." Well I was, I was uh, competing in a world class track competition at that time and I had these kids running and they would be racing me in relays and Roger didn't care for that. So, uh my academic dean said to me, "What do you know about chess?" I said, "I probably don't know more than a, a pawn from the king." He said, "Roger is a nationally ranked junior chess player." Why was I not surprised? He said, "I would like you to volunteer that Roger teach you how to play chess." So, for the next six weeks daily, Monday through Friday following our exercise period, Roger accompanied me back to my apartment and proceeded to humiliate me...

GP: Hmm.

BL: ...and did so verbally as well as on the chess board and he would say to me such things as, "That was a typically stupid blunder." In the course of those, uh, [multiplies in head] six times five, in the course of 
those thirty sessions, I may have, I may have had one draw, the rest of the time it was check mate after, you know half a dozen moves. The period came to an end with Thanksgiving and I was frankly hoping that he would not return after Thanksgiving, he did and he kept coming back. And in his senior year, of all things, he is now a resident in our building and by this time he has matured into, from being merely obnoxious as a thirteen year old, he is now a sixteen, seventeen year old agnostic fitting his family's background, un-churched.

GP: Hmm.

BL: And he is in my advanced placement English class and we are engaged in some pretty hot disputes over a variety of things. He graduates no more likeable than when he was a freshman. He goes off to a very highly selective university and in his sophomore year he begins to attend Intervarsity Christian Fellowship for the sake of mocking and disputing and two Stony Brook alumni are in that same chapter and they befriend him. And one evening in the winter of his sophomore year, the following being at the Intervarsity gathering, he came back to his dorm room and committed himself to Christ in the privacy of his own room. He told the alumni the next day and two weeks later was killed in an auto collision.

GP: [bereaved sigh with deep breath]

BL: To my total, total surprise and I will say, dismay, his un-churched parents asked me to conduct his funeral and burial because they said, "He loved you so much." [Long pause] I had done nothing; I had done nothing to deserve the affection or the respect of that boy. In fact I had done everything in my power to avoid his presence. I disliked him intensely but I had been obedience to my academic superior. He told me to submit to the boy's instruction in chess and I did it, against my will and against my personal pleasure. So that's the lesson in obedience.

GP: Hmm.

BL: Sometimes we have to do those things we would prefer not to do. And here's the final story. For reasons too complicated to go into our daughter was born in that boy's dormitory. My wife and I did not make it off the campus...

GP: [Laughs\}

BL: ...into the delivery room and so as a consequence when they were taken to the hospital, both of them were considered unsterile and were placed in, she was placed in the dirty baby nursery...

GP: Mm hmm.

BL: ...where she contracted staphylococcus and at age three and a half months was hospitalized and eventually the doctor told us, "Prepare for her death." So we came back, in our grief, came back from the hospital to that same apartment in the senior residence hall, this is now the winter of '61 and as we are in our grief doing whatever it was we were doing, there is a knock at the door and it's the very familiar and pre-emptory knock of the headmaster, Frank Gaebeline, who, you know, we all have our 
own instinctive identifications, he had a knock unlike anybody else's, so I knew it was he. And i knew this was not a convenient time to have a professional conversation so I was prepared to tell him I was not available. I opened the door and he had a habit of extending his arm and hand and beckoning with a very large forefinger. So he beckoned to me and I never got the words out, I never got to say, "This is not a good time, I cannot do this." He led me down the corridor through the building and out past the chapel and onto the headmasters residence all in the same direct line, out the building and past the chapel to a side door to a room I'd never been in. I'd been in the building and the house often but I'd never been in that particular side rear door which led to his household study. A tiny room, marked by a small leather loveseat, a small oriental rug in front of the loveseat, a single bookcase, not much else and as I stood there I noted, I noted two worn marks in the leather of the loveseat cushions and two worn marks on the oriental rug and I can now, I could demonstrate it if you and I were together, I can now envision that this where the elbows and the knees had worn places of somebody on it in prayer at that loveseat. Now I knew that by reputation, that he prayed for every student every day and that he prayed for alumni in rotation. So while I'm standing there observing all of this, he goes over to the bookshelf and takes in his hands two very thick, heavily wrapped, rubber-band wrapped stacks of file cards and he extends them to me and he said, "I don't show people these, ever but I want to show you. This stack is my prayer requests and this stack is my thanksgivings and I want you to know I have moved your daughter's name from my prayer requests to my thanksgivings." And that was it, Gabe, he didn't say, "Let's pray together." He didn't say, "I've been praying for you." He didn't say, he didn't say another word. He gave me a shove towards the door. I take that to have been an act of affection but you know, that was a shove and I walked back the same steps, past the chapel into the building, down the hall to the apartment. Now this could not have been five minutes, I mean, how long does it take to walk 100 yards, have a conversation and walk back? As I walked in, my wife greeted me with the news that the pediatrician had just called. The crisis was over and our daughter would live.

GP: Wow. [Clears throat]

BL: She is fifty years old and chair of the French department in a Christian school in North Carolina.

GP: Praise God.

BL: But as I often say, when telling that story, "Is it any wonder that I stayed for 31 more years?"

GP: Wow. No doubt. That's quite a challenge to leaders in Christian schooling.

BL: Yeah. We need to pray for each other.

GP: That's great. [Deep breath] We haven't talked at all about parents, I know we've gone for a while here so I don't want to keep you terribly long today but do you see any specific points for parents to play in the modern Christian school?

BL: Well I, well I have a family member who has said, having been head of schools, "The next school I head will be an orphanage." 
GP: [Chuckle] I can guess why.

BL: Yeah.

GP: Mm hmm.

BL: They are our clientele, without them and their support, their sense of well-being for their children, we're out of business but I will be bold enough to say that I very frequently tell parents that in the well run school they have two votes, they vote to enroll and they vote to re-enroll. [Long pause]

GP: Hmm.

BL: Now, the well informed board and the well informed administration is aware of market necessities. Find a need and fill it. First of all we've got to make people aware of the fact that they do in fact have a choice as to satisfying the need for their children's education and secondly we need to make very certain that we can, in point of fact, fulfill, satisfy. But we ought to be satisfying according to our mission, not according to the whims of a given group of parents.

GP: Good points. Well I know we've asked quite a few questions today and you've certainly been gracious in answering all of those and giving great insights and stories, so I really do sincerely thank you for taking the time.

BL: Well, feel free to call back if you need to...

GP: Sure.

BL: ...check up on something or add too.

GP: Sure.

BL: Alright?

GP: Yeah. I know, on a personal note here, I know you had mentioned the possibility of sending me a copy of your most recent book.

BL: Oh yeah.

GP: I would love to have one if you could. So, uh...

BL: Oh yeah, I'Il do that. I have the school address.

GP: Ok.

BL: OK?

GP: And, uh, yeah, I wanted to let you know, I know you're an avid runner or you were an avid runner in your day. 
BL: [agreeing grunt]

GP: I'm going to watch my son who is in 8th grade, his name is Logan, he's gonna be running the mile race today and uh...

BL: Oh, wonderful, wonderful.

GP: ...he's pushing to get his time down to about a 5:15 as an 8th grader. So.

BL: Great. That'd be just fine, just fine. It's kind of a cold day for spring track.

GP: Yeah. Yeah.

BL: I ran in the uh, in 1955, I ran in the NCAA Cross Country Championships at Michigan State. It was 12 degrees.

GP: Oh my.

BL: There was, it was a short course, a four mile, two mile out, two mile back. There was a thirty mile an hour wind in our face coming back.

GP: Oh my word.

BL: And two of my five teammates had frost bite but we got the bronze medal so...

GP: That's great.

BL: That was my, my all America experience. Well thank you very much, Gabe. Blessings.

GP: Thank you. It was a pleasure just talking to you today.

BL: Thanks, thanks. Bye bye.

GP: Okay, take care. 
Title: Phone interview Dr. Janet Lowrie Nason

Date/Time Recorded: 3/31/2011 6:36:25 PM

Record time: 1:00:09

GP: Okay, I am interviewing Doctor Janet Nason and Janet, can you tell me just a little bit about your position, maybe your title and just a little bit of what you do with ACSI?

JN: Okay, I'm the Asia director for ACSI and I work primarily with national schools in Asia so the Filipino Christian School, we have about three hundred, three hundred and twenty there. The Indonesian Christian School, we have about two hundred and twenty, we also have an office in South Korea but have not started membership among national schools. And um, I run programming to develop national leaders and also, that's the, for the, for some certification programs. And I have the fiduciary responsibility of encouraging financial sustainability within the region.

GP: Great, thank you for sharing that. And as i mentioned, I'm just gonna mention it here again, what I'm interested in gaining today are your thoughts on the development of improved learning environment for the 21st century Christian school and how you have developed or hope to develop your goals in Christian schooling wherever it might be. I'm also interested in hearing a little bit about the core values and beliefs that embody your work as a Christian educator, administrator, and consultant and so my questions will kind of focus in and around those so if we wander a little bit that's alright, l'll try to keep us on task but if there's something that you really want to talk about that i might not ask l'd be happy to hear that today too. So, first question, what are the key elements that you believe should set Christian schooling apart from secular schooling especially in the 21st century?

$J N$ : The key elements that should set Christians schools apart from secular schools. Well, first and foremost, in that we have a unique philosophy and that is what makes us different and you know, uh, we have a faith in Jesus Christ and that impacts the total Christian school, so, that impacts you know, what we believe about eternity, what we believe about the nature of children, what we, the values that we have in hiring and identifying teachers that will carry out that philosophy in the classroom and impacts discipline, administration, board, uh, everything.

GP: Very good. What specific needs of the students in this particular generation stand out to you as unique or maybe even different from past generations you've worked with?

$\mathrm{JN}$ : They believe in relationships and so it's important to have relational teachers in the classroom that validate individuals and are concerned about individual students and care about individual students. So this generation is relational in a way that has never been before, so traditional methodologies of education where you dump in some Bible or you dump in on a cookie cutter model a little bit of math and science, you know, and the focus just on content is not cutting it in this generation. You know it's so important for teachers to be relational, I think that that's a major issue. I think that, you know, with 
different aspects of society, that the family has changed and children are coming from single parent families, grandparents are raising children, and there's not the situation where mother has the financial freedom to stay home and raise children so mothers usually working and so I think that the children have changed and children have become more independent. They're growing up very quickly and that's, this, all of my comments I'm gearing to the US although there's application in other countries as well that I think, and they have, are text savvy in a way that we have never thought of and they're connected and are able to get information at their fingertips and so traditional models of learning the capitals of states is kind of ridiculous because you're telephone can tell you what the capital of the state is and so, if their phones are connected to the internet, they have access to instant information and facts and so, memorizing and knowing all those facts are not really important.

GP: [inhales as if to speak]

$\mathrm{JN}$ : And, another thing, another aspect of that is that communication is not based on old standards, handwriting and correct spelling, it is the, the content that is important not the form of the communication.

GP: Mm hmm. And you, you definitely anticipated something that I was gonna ask and that is could you make some comparisons between the US and students in other parts of the world in the comments that you made, are there some similarities there as well?

JN: Yeah, um, students in the Philippines all have cell phones, they text and talk at the same time, they don't text and drive because they don't have, they don't have the money to be able to do that.

GP: [Chuckles]

$\mathrm{JN}$ : But they, you know, have those communication skills, and overseas they, I wanna say, bastardizing the language, the English language and the way that they write it, you know it's just all, you know, the spelling is not at all what is traditional. [Laughs] And, I would say, the leaders over there, the, in the Philippines as well as other places, leaders communicate by text, texting and so you can have people that have their doctorate degrees and you read a text message from them [Laughs] and sometimes I have to say it out loud, I usually can figure it out. And it just comes across to me as highly creative but you know, they're fluent in other languages but they are also texting primarily in English which is fascinating to me, you know and they can multi-task much better than this generation of Americans. Leaders say that I was just livid at this ACSI conference because they will talk and text which is highly annoying to me that you don't have full attention...

GP: Mm hmm.

$\mathrm{JN}$ : ...but in board meetings, in other meetings they're all, well that's more leadership, but most students have access in the US phones are restricted but over there, I would say in lots of school in Indonesia to the students are on the phones. And, in China that's definitely the younger generation in China and 
they've taken cheating, cheating on exams and cheating on tests, this is not necessarily the Christian schools but, to a whole new level to where it's community cheating and using technology.

GP: Wow. Yup. It's quite an issue and I know when the AP [clears throat] letter that just went out to me as a coordinator there was just a mention of many, many schools in the US losing their status as AP providers because of texting and cheating and they were concerned that it was even a worldwide issue that some of them here might pick it up here and text it clear across, you know, the world.

$\mathrm{JN}$ : Oh well that's, those are the biggest issues, when some of the major cheating in the world is Koreans texting here to cheat on English requirements, you know, the English language test to get into graduate school...

GP: Hmm, hmm.

$\mathrm{JN}$ : ...and, or, or even undergrad, I mean undergrad or anything.

GP: Yeah, it's fascinating. It's uh, you could almost see a couple doctoral level researches coming out of the whole linguistic area that you're talking about and also just the, you know, maybe the correlation with integrity issues there as well.

$\mathrm{JN}$ : Character issues are very significant, you know, the, the overseas in, in, you know, in Asia there's a culture of corruption in the Philippines and Indonesia in particular. The US doesn't, the US would not, I would say, we do not have really the culture of corruption, you know we work towards a culture of integrity but over there it's the culture of corruption and you know, technology is really used for corrupt purposes. And, there's, you know you can buy the pirated software.

GP: Oh yeah.

$\mathrm{JN}$ : And in countries where there's poverty you know you can buy the latest movies and software and, you know the intellectual capital issues are very significant.

GP: No doubt, well kind of stemming off of that then, what technological needs do you see as essential to be taught and used in the 21st century Christian school?

$\mathrm{JN}$ : I see distance learning as being, you know, a major issue. I think every high school child should be, have to take, a distance ed course and learn how to communicate with a teacher you know be a distance ed and I think that that would be synchronized and asynchronous learning and how to develop community in a chat room and support each other and answer questions with different white board techniques and interactive techniques, that is the way they will, many of them will find that they will go to college and graduate school and it's critical that they learn how to do that.

GP: For sure, just being able to interact with their peers in that way. Um...

$\mathrm{JN}$ : And I think I do think that it is while the slang texting is the way that they communicate, I really believe that it is still very important to know how to spell and how to write and have correct grammar 
because when you don't see people and you're only communicating in cyberspace, all they know, all an employer or future collaborator knows about you is the quality of your writing.

GP: Sure.

JN: So it's critical that our Christian school students know how to express ideas and how to formulate papers and develop arguments in Standard English form.

GP: [Chuckles] Yeah. In talking with Bruce Lockerbie, one of the things he gave praise to is the fact that in tenth grade he took one semester in typing and I said, "Amen, I did the same thing in eleventh grade in a public school and, in my mind it's one of the biggest elements that I learned in, in all of high school was how to type and how to type well."

$J N$ : But let me tell you the difference, you know, ten years ago when I was the Elementary Principal at Charlotte Christian School, we had IBM people in the school and so I wrote a proposal ten years ago to get sixty computers into that school, maybe even a little more than ten- no, no, no, this was like fifteen years ago.

GP: Mm hmm.

$\mathrm{JN}$ : And, so we were given sixty-three computers for the elementary school and then I, as the principal, went to the high school typing teacher and said, "Now i want you to teach my fourth and fifth graders how, keyboarding skills." And that was a hard sell, me having to go to them and do that. And then I had to, I was at the very front end at the getting my teachers. WE put four or five in a classroom there and then getting them to integrate the technology. We did not, we did have a middle school lab but I put them so they would be accessible in the classroom. But then we taught keyboard-, then the typing teacher did teach that and you know, my, actually, my son in fourth grade, he's twenty-seven now, but, okay that would have been like, yeah, fifteen, sixteen years ago. Then his, his teachers in fourth and fifth grade taught him to be like, how to help other students to be a peer collaborator then when he ended up going to Wheaton, and then he worked in the computer lab. And now, you know, he's doing research at Boston College. Like, he was on the front end of learning all those technology skills and then that was the thing, one thing that I invested in was the latest computer. And, just the little bit of ability above his peers and being on the front end of that, I see has positioned him in incredible-, in an incredible position that now he is collaborating around the world with this research project. That came out of that. Anyway.

GP: That's great. That's great. Can you identify maybe two or three necessary changes you believe teachers must make to reach students in the 21st century?

JN: Absolutely. Relationships, number one. Teachers are so focused on content and just spouting out content and they are not connecting with students, so, if teachers do not, if high school teachers do not look kids in the eye and smile at them and have something personal to say to them, the kids think they don't care, they don't like them, and so, it's all about relationships. And this is just critical in the Christian school because you know, the nature of what makes us unique is our relationship with Jesus Christ, so 
God is a relational God, there are parts to the godhead that communicate, that's how God communicates to us and so, it's about relationships. And then, I also think communication skills of writing that we already talked about but I'm also going to put speaking there, you know, children do not learn to communicate well in sentences or stand up in front of a group or you know, be able to communicate well even on camera. You know? They're shy, they don't wanna talk, sometimes, so, as society moves to become more and more collaborative and video conferencing is taking place and needed in the work force, it's just very important that children can articulate in English very clearly because they're going to be communicating with English Indian speakers, Philippines who have a different accent where all the call centers are located, Australian English is different, British English is a little different, so to be able to put your endings on words and speak clearly is, I believe is an important skill for the future.

GP: Okay. [Clears throat] Recently have you made any suggestions to particular teachers as to how they might change their teaching to reach today's students, if so what were they?

JN: Have I made any suggestions to teachers about changing their teaching? Um, I, I, you know, my, I speak sometimes at conferences. I was just teaching in Indonesia our foundations course on philosophy, so ACSI Certification Program now counts for half of the Master's Degree. It's the most sophisticated, developed teacher training program in ACSI, and administrator training program really modeled off of the two Masters programs at PBU that I directed, so anyway, I was teaching the philosophy course and this time I really emphasized relationship because it, it's not that this is just a good idea for teachers, this is modeling the master teacher. If we are going to have children develop into spiritual champions, they have to be able to listen to God, to be able to read the Word, and to be able then to communicate and so if we're not really teaching that, then that's a problem. And I also am, I also emphasized non-North American teaching on community that this country is a very, US is a very independent culture, you know, the culture of the US, is that we are very independent and independent thinkers and you know, you make it on your own and you do it alone, the American Spirit but I don't think that that's a Biblical model and I think that the US has a lot to learn from Christian schools from Africa and the US than other community based cultures. So I really emphasized the fact to teachers that we are a learning community and we need to learn faculties need to learn to function in community, students need to learn to function in community and it's we're just in competition with the other students in classes but we are in community with them and we have to have Christians starting to get along with each other.

GP: Hmm. Amen. Are there some specific steps, Janet, that you feel could be taken quickly in many Christian schools to bring about this type of environment that you've been talking about, with the nonNorth American approach and the community of learners?

JN: Specific steps to build community? Uh... uh, yes and I think teaching and evaluating, valuing, teaching and valuing people, you know, a staff of a Christian school, children in a classroom, cross-, let me also say cross gender that um, you know, there's a need in the Christian community to value male and female opinions and to not look down on females that are paternalistic/maternalistic authoritarian 
perspective and so I think that there needs to be much more respect in this country given to cross gender relationships and cross cultural relationships so nobody should be judged by the color of their skin or the shape of their eyes. So, I think many Christian schools could benefit on diversity, you know, intervention and teaching on diversity within the body of Christ and also what could be done is reading and learning from leaders in other cultures as opposed to just thinking that somehow the American culture is a superior or Biblical culture.

GP: That's great.

$\mathrm{JN}$ : So that means, you know, learning from the Chinese, learning from the Africans.

GP: Mm hmm. Do you think, I'm kind of going off my script for a minute here, but you've intrigued me? You know my background in missions and such.

JN: I don't know your background.

GP: Oh, you don't? Oh, well I'll give it to you brief. My wife and I and my two boys lived in Romania for two years and so we worked... [Voice fades out]

$\mathrm{JN}$ : Oh, yeah at the international school there?

GP: No, actually we worked in a small orphanage in...

$\mathrm{JN}$ : Where?

GP: ....in Brad, Romania which is...

$\mathrm{JN}$ : Brad?

GP: Yes.

JN: Okay.

GP: Yup, so we were there for two years and worked with a, uh, about twenty orphans and then those ranged in age from four years up till twenty, twenty-one, a couple of them were in college at the time and then we also had a Christian center in the town there where we had English clubs, you know, ELL and, uh...

JN: In relationship to Timisoara, um and Oradia, where's Brad?

GP: Brad is gonna be southeast of there about maybe three hours.

$\mathrm{JN}$ : Into the Carpathians?

GP: Mm hmm, definitely into the Carpathians.

JN: Okay. 
GP: Yup. Definitely. So with that, you know, I would say, I, I'm intrigued by what you're saying, I am going off script here just for my recordings sake, I'm saying that. But, do you see ACSI maybe bringing some of these leaders that you, that are identified as you know maybe very gifted at what they do in Christian schooling um, coming to talk at some kind of an ACSI conference because I've seen us do some things but I've never seen, you know, I've never sat in a session where let's say a Russian Christian school educator taught me how to do it, you know.

JN: And I don't think, I rarely don't, and I, I think, you know that Europeans, now I would put Romanians in a little different category are still fairly similar in the way that they think because the cultures of Europe are still very similar to American cultures. They're not community based cultures. Now Romanian with the Latin roots...

GP: Mm hmm.

$J N$ : ...coming out of there, is, is a little more like Italy is definitely as a culture, and the Spanish community is more community based. Germany, you know, very independent and even, you know more independent. So, I think that, you know, it's the, it's really where the church is growing. So the church is growing in Africa and Asia even and in Latin America, but Africa and Asia by leaps and bounds. You know I think that there have been a few times where non-North Americans have, you know, come to the US but, you know, it's expensive, you're talking about maybe from Africa, it may be a $\$ 2000, \$ 2500$ dollar ticket to come and go there. And from Asia maybe $\$ 2000, \$ 1500$ to $\$ 2000$ dollars and you know, anyway sometimes that's prohibitive.

GP: Mm hmm.

JN: And ACSI financially is, oh I guess, I'm being recorded here but there's not a lot of extra money within ACSI right now because membership is very flat in the US so if you look at membership numbers, uh, flat and down in the US, down in Europe, up a tin-down, no down, really this year down in Latin America, up by $5 \%$ in Asia, up by $50 \%$ in Africa.

GP: Mm hmm. Hmm. Very interesting.

$J N$ : I don't know if you know this but for December was a tipping point in terms of membership of individual students that for the first time the number of international students in ACSI schools is now larger up for those outside of North America than inside. So, that means that there are more children in ACSI member schools outside of North America.

GP: Hmm.

$\mathrm{JN}$ : So that is significantly these, the international trends are definitely going to be impacting ACSI and the Christian school movement in the future. 
GP: Mm hmm. I'm gonna ask one question that kind of ties in, I think, with something that one of my other interviewees mentioned. Are those Christian schools in other countries opening their enrollment, meaning are there known non-Christian students and families enrolling in their schools by in large?

$J N$ : Well you know, there's uh, you know, it just depends on what the mission of the school is. So if the mission of the school is often the outgrowth of a, you know, a, well let me tell you it this way. You know, there's open and closed enrollment and you know if you are discipling students and then you are usually taking children from, you know, at least one of the parents is probably, there's a requirement as a believer. If you are evangelistic in outreach then you, you use the Christian school as the mission field and you are set up that you want to bring children to Jesus Christ in your school and then disciple them.

GP: Mm hmm.

JN: So, you know we have different, around the world different schools are set up for different reasons but I will say that Buddhists, Hindu, and Muslim children are coming to know the Lord every day in different Christian schools in Asia.

GP: That's great. Okay, thank you for taking me down that path, it was fun. I'm gonna go back to the question script here. If you're involved, or as you've been involved in a hiring process, what qualities or characteristics would you look for in applicants to provide students the kind of Christian education you've been talking about?

JN: Okay. So what would I look for, today, today if I were hiring? I don't wanna think back to the past, uh, when I was a principal. You're talking about today?

GP: Yeah, in this 21st century to bring about... [Voice fades out]

$J N$ : Like if I were a principal right now?

GP: Mm hmm. Yeah.

JN: Okay. Okay. I, I would specifically because of this spiritual development issue, I would hire teachers who are highly relational, so, you know, that, that presupposes that they have their academic credentialing, that they have certification. I would look at a Masters at least in hiring if I were in a school but then that they have, that they have relational skills so that means that they are good communicators and that they like children and that they have the technology skills for this century that, you know, they are comfortable on an Ipad right now, this is what I would look for that...

GP: Hmm.

JN: ...it's not just, it's not the keyboard traditional skills it's that they know how to access video clips and definitely moving from PowerPoint to video clips and how they use video to connect affectively with students and that they are up on what students are doing with technology so they're able to speak the students language when it comes to the language of technology. That is, you know, way above, I see, and the reason that I say this is because I've seen with my, uh, twenty-three year old daughter that the 
way that she teaches now, and the way that she uses technology and the boards that she has and integrates more video in her teaching then like traditional still pictures that that is energizing to students. Students connect with that because that's what they're interested in. So, and I really believe that she was able to get her job because of her technology skills, that is what set her apart from some other applicants. I would also say that, you know, I do not, I would not hire teachers who just have a North American experience or mentality, you know i want them to be really world Christians, connected and interested in what God is doing around the world, you know, not just in this country. And, you know, all of the news or, if, if North Americans listen to anything it's just Europeans news and familiar with European issues but the future is in Asia and the future is in Africa and that's gonna change the dynamics of everything and so, I want teachers who are, know what's going on in China and India and Indonesia and are able to communicate that.

GP: Very good.

$\mathrm{JN}$ : I also want teachers that do not have any racial or gender prejudices so I want teachers that have respect for each other, who can teach that to children, you know, and because our society is not just a, you know, a white male society that, it's so important that teachers have respect for different cultures and you can have it, and, and also can disagree with other Christians in a very civilized way that there's a mixture of different denominations that is respectful, not that, "oh I have the inside on truth and we're judging all the other denominations that are below us."

GP: Hmm.

$\mathrm{JN}$ : Anyway, sorry I maybe said too much about that.

GP: No, that's very good. I appreciate that.

$\mathrm{JN}$ : But I always say I think that there's a lot of Christians around the world that are gonna be very surprised at who's living next door to them in heaven.

GP: [Laughs] Very true, I'm sure. Well, uh can you tell me about a time, whether it's been recent or maybe it might even be a combination of events that come together in your mind that make you feel most positive about your work as a Christian school educator, maybe times where you knew your goals and values were being met, you know, kind of hit right on the bulls eye?

$J N$ : Well, my passion is the development of national leaders and you know, I did focus for ten years in the US and started masters programs in Germany and Thailand thinking that they were just going to be for, you know, Americans but now, you know, that speak English but now my passion is the development of Christian school leaders in Asia and really around the world. We've had this program in Indonesia; Indonesia just has very poor education courses at the University at Rabal so there's not any courses in curriculum, evaluation, models of teaching, understanding the nature of the learner, et cetera. So, uh, six years ago, seven years ago we set up the certification program in Indonesia and I offered it in Jakarta and Surabay, the two largest cities and was thinking, you know, that we're gonna be 
developing a top tier of leadership and then two years ago when I was very excited to be in Australia and talking to a university there that would give this graduate credit for this training and so we offer it in two places in English but graduates of our program have now been teaching it in the language of Masha in Zanzibar so I, I just came back from Indonesia so I'm talking, what I'm most encouraged about is that we graduated the second rotation, well let me just say this, in Jakarta and Surabay, the largest numbers that we ever had is maybe ten in a class, ten finishing the, all of the courses which is eight. So our graduating classes have been about ten, ten to fifteen but then in, in Bali, in Zanzibar, we just graduated thirty-two from that. This was our second rotation of teaching the classes there and now our graduates now, and the class that I taught, that, we're starting the seventh rotation I believe now in Surabay which is the second largest city where ACSI's office is located. I believe that I had, um, thirty five in the class and then about forty-two in the class in Jakarta. So our numbers are going up in this program and that's, that's the bottom line. And, we have offered our third masters course by bringing the Australian professor up to preach and then the balance is to teach a short class and we're doing that in a cohort style and so they're coming in for an intensive but then the balance is done online. So, I'm very excited about the numbers that are coming into that master's program. So, um, you know, I just see a sustainable model of Christian school development there that is, I, I'm, I bring professor types from, well I brought a former student to teach, this is to teach Indonesians, um so she comes from Cedarville, from China and then um, you know I brought some from the US to come and teach in that program. So it's a very cross cultural in the sense that they're being exposed to professor types that are some from North America but a lot of non-North Americans too. And, I'm really excited about that program.

GP: That's really neat. Are there any specific situations, events, maybe mentors that have changed the way that you view Christian education and the way you relate with students, parents, and colleagues?

$\mathrm{JN}: \mathrm{I}, \mathrm{I}$, are there any events or individuals that have, that impact the way that I relate to students or colleagues? That's what you're asking?

GP: Mm hmm.

JN: Definitely technology has changed the way that I communicate. I, I'm a connector and I just see that with technology, I'm a super connector now uh, individual. So, I really don't think, I don't think just within an individual, you know when I was at the graduate school, I started off just thinking about the Philadelphia area but then with the internet and I pioneered some of the first distance ed things there then, and then starting the campuses, I think very globally so that has really impacted the way I think about the Christian school movement is because I truly have friends around the world that are really non-North Americans too. I don't function in the MK Missions Community is that my good friends in Asia that I'm closest to are Asian and so I see the global diversity within the Christian school movement and I'm able to keep in touch with them because of technology. I don't know if that, does that make sense to you?

GP: Mm hmm. Definitely. 
$\mathrm{JN}$ : I don't know if I'm expressing that well. So, the technology and then I really believe since I've gone overseas that, then I bring a lot of internationals here to, to see IU, I teach at, I run the Internal-, I direct the international comings there to the international institute for Christian school educators so, like we have fifty in that, that came to that last year so as I have listened not talked to been in other countries as I have become a listener of international and listening to non-North American leaders talking about their relationship with Jesus Christ, about spiritual issues, about educational issues, about social issues. You know, I have learned so much and that has changed my opinions so much and as I have read nonNorth American, particularly Chinese and underground church in China, I would, if you haven't read, "The Heavenly Man" or "A Living Water" I would really commend those books to you. People who really know what it, faith, at the faith, what our faith is about and you know, journeys of faith and understanding faith in significant ways and that's changed me. That's changed what I think about the body of Christ and that's changed what I think about Christian schools and you know, it's not just passing off Bible knowledge, that's very significant to me, it's not about more Bible courses or more Bible knowledge, it's about obeying what we know. Anyway.

GP: Very good, thank you. What about parents? What role do you see parents playing in the modern 21st century Christian school?

JN: The role of parents in the Christian school? Well, we need, the Christian school needs to be connecting to this generation of parents. And, they need to understand that they're different then the last generation and parents they want to know how to access information about their children, about the school, about sports games, they want to be able to get instant information about their children, about their children's progress, about behavioral problems. They want to be able to, to, to track and have report cards come electronically. They, uh, and so many of our Christian schools are not positioned to communicate with this generation of parents, and, um, you know, the old ways of communicating with parents by just writing notes is gone and so if we, if the Christian schools wanna engage parents and really have them as partners we have to know how to communicate with them and we have to give them information and help them in that. I don't know if that... [Mumbles out]

GP: Definitely. Yup. Yup. And actually just to encourage you on that point that the other two that I had already talked to had said differently but there's some threads there that are, that are certainly the same.

$\mathrm{JN}$ : I also think that parents want to get the most for their money and so and parents you know negotiating college choice is a big, that's the most important decision, is the outcome of our Christian school. Like where they're gonna go to colleges and universities and $i$ think that the more Christian schools can do to offer, they want value for their money. So, to offer more AP classes so children can take you know those credits into the university. so, i saw this with my son and as a single mother it was hard for me to go to the, to pay the money but the fact that he was taking AP courses and did well, you know that saved me a year's tuition at Wheaton which somebody just told me today is like $\$ 35000$ or something. 
GP: [Laughs]

$\mathrm{JN}$ : And so, the more schools can do to look at the AP route and then also look at the dual credit route that while they're in high school they are earning college credits, I think that that is very important for parents.

GP: Very good.

$J N$ : And that makes tuition, you know, tuitions are high but if they're able to be working towards college credit or getting credit, you know, then that's gonna be a selling point.

GP: Very true, well I know I've asked you quite a bit and I'm really appreciative that you took the time to talk. I did have one last questions just to kind of open it up, and if you feel up to it. Are there any thoughts that you still have that we might not have talked about already that are ideas to transform Christian education in the 21st century? Is there anything that you know you might recommend me to think about or read or just understand in general...?

$\mathrm{JN}$ : I think, you know, this latest trend about dual, definitely the trend towards dual credits being offered in Christian, in schools, so that you know that high school students can be getting college credit. I think that this was done like to change the landscape of, of, of high school curriculum in the future and I do think that schools are gonna move from an AP model where students have to score, you know a 1-5, to where there's gonna be a lineman with different universities and Christian universities and things are definitely moving more one line but if they can, if they can be getting college credit I think that's going to revolutionize things. So, I see, I see that and I also see an issue of the multiculturalism and that more and more international students are going to be coming to the US. I see this as a major trend in Christian schools and Asians because education is so valued in Asia and Asian countries, have a higher socioeconomic status, many of them do and the Koreans and the Chinese coming to the US is gonna increase and Christian school are gonna have to set up programming for housing if they're coming from nonChristian backgrounds there has to be well thought out curriculum development and many of them are coming with money and so if you have non-Christian Koreans coming into your school with money there's just such a need for integrity and for, Christian schools have to understand that. This, this is an issue with Koreans coming into Filipino Christian schools because they wanna learn English and then they want to come, go into, and if they can't come to the US to learn English since that's the language of instruction in schools in the Philippines. Then they come to the Philippines to learn English so they can get into college and or graduate school in the US.

GP: Mm hmm.

JN: So there's gonna be, you know, the diversity is going to increase within American Christian schools, it already is. There are many, many trends in that direction and um, Barret may have talked to you about that because they have a program at their school too.

GP: Mm hmm. 
JN: So, many, many Christian school administrators, you know, are starting to look to Asia and take to trips to Asia because that's helping their budget bottom line.

GP: Mm hmm. Mm hmm.

$\mathrm{JN}:$ Anyway...

GP: I know here at Lititz Christian we actually are bringing on April fourth yet another round of students from a school called Toyo in Japan so we have a connection directly with them. My family and I actually just hosted a Japanese girl, a junior in high school this last year.

$\mathrm{JN}$ : Yup.

GP: And then we have two South Korean students and we'll be getting next year, one Chinese student.

JN: Yeah.

GP: So, it's definitely a help to the school in many, many ways, I think of trying to build community as a principal to have our kids reach out so starting to see the results, they're really catching on.

$\mathrm{JN}$ : Yeah, but it's an issue to have, there has to be well thought out development, you know, in if you're paying families to watch these children, what are expectations, you know, how do you choose, there, there's a whole new, Christian school administrators are going to have to deal with many new administrative problems and positives because they bring the money but they are gonna have to understand the culture and understand the Chinese parents expectations, Korean parents expectations, and understand, you know, what it means to the Korean culture when you give a "B" as in boy to a Korean child.

GP: Mm hmm.

$\mathrm{JN}$ : And the emphasis on grades and what the means so it's going to force Christian school administrators to understand other cultures at least they better understand those cultures so they know how to deal with those parents because those are not your typical Lancaster parents.

GP: Right.

JN: [Laughs]

GP: [Laughs]

$J N$ : But I think that's really a good thing, I mean I think that, good, good trends with diversity and that's positive but then it's just important for North American principals to understand that Americans have a culture, Koreans have a culture, Chinese have a culture, Indians have a culture and you have to be able to work with all them together and understand because they're vastly different.

GP: Hmm, it's a fascinating world we live in. 
JN: Fascinating. Anyway, good to talk to you. I'll...

GP: Yup, hey thank you for your time and yeah I really look forward to maybe connecting with you another time.

JN: Okay. 
Title: Phone interview with Dr. Barret Mosbacker

Date/Time Recorded: 3/31/2011 3:14:51 PM

Record time: 0:03:18

GP: Alright, so I'm interviewing Dr. Barret Mosbacker. I hope I said you're name right Doctor, is that right?

BM: Uh, that's correct, yeah.

GP: Okay. And you're with Briarwood Christian School in Birmingham, Alabama...

BM: Yup, correct.

GP: I'm interested in gaining your thoughts and insights on development of improved learning environments for 21st century Christian schools and specifically how you've developed and hope to continue to develop those goals in your school setting. So, I have a few questions. First of all, what are the key elements that you believe should set Christian schooling apart from secular schooling especially here in the 21 st century?

BM: Well, I think that, I believe there will be quite a few commonalities obviously but in terms of the distinctive in no particular order here obviously the commitment to a thoughtful, and I would add a humble, Christian world-view meaning that there are some things that are rather evident in the Scriptures and evident in natural creation and natural revelation, there are other things that are less obvious where big Christians are big conscious, we love the Lord, take the scriptures seriously would have differing opinions, different interpretations, so I do think it's very important that Christian schools be characterized by commitment to a biblical world view recognizing however the limits of our powers and the degree to which Christians can have some interpretation as well as a commitment to Christian liberties, so that would certainly be one thing. I also believe that as Christians we need to take the notion of being highly creative in our work to heart. It's so that, in my mind, Christian schools should be some of the most dynamic, creative, risk-taking institutions, educational institutions there are, willing to apply God given imagination and creativity and energy to what we do. I think, obviously, that that all has to be committed mature, in maturing believers, who are filled with God's spirit, that abide in Christ that they may bear much fruit. After all we plant and water but God's gives the increase. I think that teachers are the most important aspect of any educational institution. The school is always gonna need teachers and therefore those Christian teachers need to be confident, professionals in their field. So those, those would be some of the things for sure that I, I think should be reflective of the distinctives of Christian schools. I would also add the notion of, this isn't distinctive, I mean public schools have service projects for their students in many instances but I think ours ought to be reflective of the love of Christ, servant hood in a deep sense of Christian community that bridges denominations. So those would be a few of the distinctives that I would like to highlight. 
GP: Okay, very good, thanks. If I can, let me take just a moment here, I wanna look at my recording device and make sure I've got you on the right folder here. What are the specific needs of students in this generation that stand out to you as unique and maybe different from past generations you've seen?

BM: Well again, I think by and large, people are people, students are students, the generational issues tend to be pretty common, you, you can see that very easily after the reading of history as well as the Scriptures. So I think sometimes we make a lit- the distinctives that may actually exist. Having said that, I would say that a couple of the things that are different is, first off, students have literally in their pocket access to a universal world of information. I carry an iPad, reloaded, I have a whole Stone Age worth of books there, I have whole library full of other books, I have research articles, I can access the internet, et cetera, et cetera and that is true of our students as well. They are able to access basic information within minutes. So, I think that one of the, one of the distinctives is the ability to have information which means that the classroom needs to focus a bit less on providing information and a whole lot more on how to access, analyze, assess that information and a whole lot more on the issue of critical thinking, which again I think has become a cliché but it's done well, you don't have to spend much time accessing information you spend more time working with that information. So I think that's an issue. I think another one would be the whole nature of being able to collaborate online and in other forms not only with one's peers within a classroom or a campus itself but frankly across international borders. We have Chinese-Mandarin programs; our students have video conferences with Chinese students in China that would be an example. One of our Bible classes is connecting with a class, with a school in Beirut, Lebanon. So, learning the skill not only to communicate with modern tools but actually to engage in projects that are collaborative, going online is essential. Most major corporations in the world have a work force that is widely dispersed across borders and they do a lot of collaborative work online, so I think that that is an essential skill. I think another one is learning to navigate the social connectivity to social media that is so prevalent. Again, I think that it's essentially a good thing but it can be either, it can be abused and not only that but I think students need to learn certain etiquette, need to know how to protect their privacy...those sorts of things. So those would be just a few things that I would quickly add to the question in terms of what needs to be done.

GP: Great thank you. Can you identify two or three necessary changes that you believe teachers must make to reach students in this 21st century?

BM: Uh, yes. I think teachers have a, a bigger task in that there will be less intrinsic motivation and so they're gonna have to be more creative to produce an extrinsic motivation which means that they're counterintuitive initially based on research but the reason I say that is, if you read some of the, some of the more current research comparing industrialized, wealthy countries to those which are not but are emerging such as China and India, they have a high degree of extrinsic motivation because they need to study hard, work hard in order to pull themselves up out of poverty. In the United States, in Europe and other countries students lack by and large that extrinsic pressure upon them and so the teacher's job is a lot more challenging. Teachers have to be more engaging, more creative, use a lot more tools in the classroom to motivate students to work hard that include, it's not exclusive to this, but it includes the ability to actively give the great technology in the classrooms. I think also teachers need to be very adept 
at interpersonal skills particularly in dealing with parents. Parents have much higher expectations now in terms of the, with teachers communication to them. In many cases, too many cases, I think parents tend to helicopter over their children, trying to avoid them running into any kind of problems, parents aren't as quick to take the side of a teacher as they may have been in past generations therefore teachers need to be very proactive in their communication to parents and very careful about how they respond. So I think there's, there's skills there that are definitely different in light of the 21st century. Most of them are gonna be pretty much the same but those are the ones that I would essentially highlight.

GP: Great, good answers, thank you so much. What technological needs do you see as most essential to be taught in the 21st century Christian school? We know that there are tons of technologies out there and things that could be learned but which are those that you feel are essential to the current student?

BM: You know, I think two things, I think less teaching on the actual software and hardware because that is very fluid, it changes very rapidly. I think the focus really needs to be two-fold: one, at the teacher level and one at the student. At the teacher level, I think it has to be using technology in a highly integrated, embedded fashion, that is technology, if what the teachers are doing is, is having students to search the internet, use a word processor for notes and, and writing projects and use PowerPoint or keynote for presentations then the technology is being woefully unutilized and there's a minimal return on educational investment. What needs to happen though is that there needs to be a lot more project based learning in which students have to use in the classroom and outside of it various pieces of software and hardware in order to accomplish the task much like they will do in any other professional field, so they may use Excel spreadsheets to model information and present data, they may use databases to collect and correlate information, they can use word processors, other very specialized software that they might use in their science courses but basically use all of those tools in a very seamless sort of fashion so that the technology's not the focus, it's just a natural tool that is utilized in the context of the teaching and learning process. So, I think that would certainly need to be the focus of what teachers would be doing. I think in terms of the skills for students, it's a little bit what I had said previously, I think they really, they need to be focused upon learning these collaborative project skills, utilizing technology and non-technological tools and resources in order to foster that, you know, their learning. So, I'd say in the classroom those are two things. The other one I think that is critically important is distance learning both at the student level and the school level. We are incorporating a number of distance learning courses; the prediction from Doctor Christiansen from Harvard is that by $2019,50 \%$ of all high school courses will be available online. That's expected to continue to grow very rapidly and so, and many students take courses online even when their resident students at University so they need a familiarity with utilizing online course content and the schools need to provide that to enrich their own curriculum and perhaps to make their curriculum available to other students and, or other institutions as well. So those, those are things I would immediately highlight.

GP: Very good. Are there some key issues that you believe currently divide students and their teachers in this 21 st century? 
BM: I don't think any, I don't think there's anything particularly unique to the 21st century relationship between students and teachers that perhaps has always existed, if there would be one, it might be the phrase has been used, the students when they walk into classrooms, "Power Down". I like to use the phrase, I heard someone say, I don't recall who or I'd give a name but they said basically, "We have Jetson students walking into Flintstone classrooms" and so, I think that's probably gonna divide sometimes exist, students are connected twenty-four seven essentially, they go to the technology for much of what they do and yet that's not always the case when they walk into a classroom or when they're engaging with their teachers and I do think that there needs to be a, a meeting point about halfway. Students need to understand that good learning, good interpersonal skills, good instruction can take place without the technology. Teachers need to understand that the technology rightly understood and rightly employed can significantly enrich and expand what's happening in a classroom. So, that, that's the area that I would tend to think would be the primary divides of the 21st century.

GP: Okay, have you made any suggestions to teachers as to how they might change their teaching to reach these modern students?

BM: Well, yes but once again I think the notion of modern can be a little overstated...

GP: Mm hmm.

BM: ...but I will say that one of the things we have focused on for three years is we have brought specialists in from Harvard and other places to train our teachers on the neural and cognitive sciences, the structure of the brain, how the brain learns, and then how that should affect the way that they teach and the way they assess students. So, I would, I would say that modern cognitive-neural sciences is a critical component for modern teachers and once again, I think that the ability to advance the technology effectively is an important issue as well.

GP: Good. Are there any specific steps you personally feel must be taken quickly to bring about the type of learning environment that you're talking about with the cognitive and neural science studies of the brain and technology integration points?

BM: Yes, what we do is one, we're very intentional in all of our professional development programs are multi-year and scaffolded so we do not have training du jour as it were. We determine what is most essential for students and the school and then we're committed to that training over multiple year periods bringing it up to increasing levels of sophistication and application over multiple years. That training is followed by a high degree of accountability, so for example, when we deploy lecture technologies or smart board technologies or iPad tech, iPad in the classrooms or whatever it might be, it is not an option for teachers to utilize this learning and these tools, uh, it's required. They're evaluated based upon doing so, they're obviously gonna receive lots of help and support but I would say, intentional, multi-year scaffolded training combined with high degrees of follow-up throughout the year over multiple years along with the very specific accountabilities are absolutely essential if in fact teachers are gonna change. If, if you don't do that what happens is you have training for four or five days, a week then teachers go back to their classrooms, they close their doors, and they pretty much do 
what they've always done before. They end up in their classroom silos and nothing fundamentally changes. So, if you're gonna have specific change within the schools culture, you're gonna have to stay in multi-year training, you have to be focused, it has to be ongoing, scaffolded in levels and sophistication and high degrees of concrete accountabilities that, the way we frame it is, you cannot not do this and teach here. So it's not an option, this is what we do, this is what we expect, this is the tools we're providing, these are the tools we're providing, and we will help you, we'll encourage you, we'll find support training but you will do it and so that's the approach that we're taking.

GP: Very good. I like that approach. If you're involved in a hiring process, and I know you are, what qualities or characteristics do you look for in applicants that will provide the students and the parents with the kind of education you've been talking about?

BM: Oh boy, well that's a big question. I'll list several things, I'm not ranking these.

GP: Okay.

BM: With the exception of the first one and that is obviously as I said before they have to be a very articulate believer. They clearly know Christ; they're mature, and maturing in the faith. So that's very important. They need to have the gift of teaching, you know if they don't have the gift of teaching, we can teach certain skills but if they're not gifted they're still not going to be a highly effective teacher. For example, I'm not a particularly good basketball player and I can go on the court and the coach can teach me all the skills he wants and although that proves some but if I don't have the gift to play basketball, I'm never going to be a great basketball player. So, teachers need to be gifted to teach. In addition to that they have to have very strong interpersonal skills. It's very important that they are able to communicate clearly and effectively but in loving way with students, parents, and peers so that, in that they have the ability to relate well to communicate well. They need to love students more than subjects. Remind, remind, remind teachers that they're teaching students not a subject and that makes a big difference. They need to be teachable no matter what their age, willing to learn from others, willing to admit mistakes, willing to grow and develop as a professional and as a human being. They, they need to uh, not only be teachable but also learners not as a cliché but their willingness to put forth the necessary time and effort to learn new skills and to learn these new tools. Again, technology would be one example, learning the neural sciences and how that should affect the way you teach would be another example. And so, they just need to be professionals who are constantly learning and that go along. So, those, I mean there are a lot more things but I would say those are essential things that I would be looking for. Obviously subject matter, mastery is critical for any teacher. So, I would say those are the primary ones, not the only ones but those, those would be primary. Other skill sets you know class room management, teaching pedagogies all that we can teach, we can teach people if they have those other skills sets, we can teach them the technical skills they need.

GP: Very good. And at your school as far as the compensation packages and so forth goes do you feel like you're comfortable with the request that you're making on teachers and the compensation that they're receiving per their level of background and capabilities resume wise? 
BM: Oh yes, we're very blessed. We have about 1,960 some students and we have, the Lord has provided us good resources and so we're highly competitive in our salaries. We average in any given year, we have 200 employees we may end up hiring 5 to 7, 8 faculty members in any given year and we have somewhere in the neighborhood of 250 applicants for those positions. So we are able to compensate both in terms of salary and benefits very competitively.

GP: Tell me about a time that you felt most positive about your personal work in terms of meeting the goals and values in Christian schooling that you were putting forth. Is there a specific memory, an instance, something recent or in years past that just really stand out to you as a key moment in just watching your goals and values being achieved, played out in a Christian school setting where you were teaching or administrating?

BM: No, I couldn't think one. I see this a lot over a long period of time, so, it would be very hard for me to identify an example when frankly in any given year there are multiple examples of that sort of thing occurring. Obviously whenever a child, particularly in our elementary program or any child for that matter, receives Christ as a result of the witness of a teacher and that sort of thing, that's obviously very profound and meaningful and sort of a culmination of what you certainly want to see but I mean, we, we get letters back from alumni who talk about how they got in college and our world view and apologetics courses prepared them well to humbly and graciously access what was being said and respond back appropriately and felt like that we had not hidden the truth from that, that we were fair, calloused in the way we presented issues such as evolution and a number of things so that they were prepared for these discussions. You know, when we go and we send our students overseas for medical missions teams in the summer and you have hundreds of people come to Christ, you have hundreds more receive medical care, those would be an example of Christianity and a worldview put into action for social injustice and spreading the gospel. So yeah, I mean, there's there are a lot of those sorts of things that one could point to but it'd be hard to pick one out.

GP: Sure, well just to let you know it was similar response from Bruce Lockerbie when I talked to him not too long ago as he said the same thing. It's kind of hard to pick out one instance...

BM: Yeah.

GP: ...so having kind of a sweeping view like you did is very common, I think. What specific situations or events have maybe changed the way you view Christian education or the way you relate with students, parents, colleagues, and other stake-holders?

BM: Again, I don't think there's a situation per say, I would say that I do a lot of reading and research and I, I think if there's one thing that I've become very concerned about is, how do I say this? A tendency of too many within the Christian school community to not engage effectively and positively with modern culture, it's either a dismissive attitude towards developments, modern developments with a social bee and technology and neural science, whatever it is or it's a focus on all of the bad negative things rather than proposing concrete positive solutions to the communities problems or there's not enough emphasis on giving students a very vibrant, positive message of what it means to live in this world to 
God's glory. It tends to be focus on the woe is us, woe is the culture, woe is sin, woe is that... don't do this, don't do that, avoid that, be careful about this and that simply is not a compelling vision for life nor is it one I think that God intends for us to give or that he gives us. And so I think probably the thing that I have noticed that tends to motivate me a lot to address this in Christian circles in a general marginalization of the Christian school movement and Christian school leaders because they tend to be so miopic and provincial and focused on the traditional, the conservative, et cetera that I think, I think that they lose their voice. Not only do I think they can lose their voice for students but I think largely lose their voice to the culture. One, one way I noted this and I do different presentations across the country in Australia and stuff on a couple things and so, one of the things I put on a PowerPoint slide is I have three pictures, one of Steve Jobs, one of uh, of uh, let's see, Steve Jobs, uh, Zuckerberg and Smith from Google and how and two of them are Buddhist and one of them, I don't know what he is. And uh, no I'm sorry, one is Buddhist and one I don't know what he is and yet they're reshaping our culture and so my question is, "Where are the Christian innovators? Where are the Christian innovators in Christian schooling?" We're shaping the culture rather than falling way behind and throwing, casting stones. So, I guess, my concern is the lack of excited positive, vigor and energy and creativity and innovation within the Christian school movement that I think is vital to prepare our students to taking every thought captive and to impact the culture for Christ. So, that may be more than you're asking but generally, I guess, that's how l'd respond to that question.

GP: That's great. That's a compelling vision, very challenging. I like it a lot. How could you see your methods, those which you've mentioned already for adapting the needs of current Christian schooling, to be specifically brought to the minds and methodologies of our current Christian school teachers, whether they're on your faculty or let's say on my faculty?

BM: Good question. Well, I don't know. I can't claim that these are the most effective. I can tell you some things that I'm doing in the Lord's providence. One, I have blogged and it was read by ministries in the United States, Canada, and Australia. I get very good response on that so hopefully more use that in some small way. I do collaborative video conferencing across the country with different administrators. In addition to that I'm actually developing some short videos online and with others kind of a podcast sort of process. I have created, I use Twitter personally but I haven't used it for that purpose yet but I'm considering it. It's more of a time limitation more than anything else so what I'm trying to do is employ modern communication tools to try to share ideas and thoughts with other Christian school administrators and teachers just even in thinking that they may or may not agree but I certainly want to stimulate their thinking. I also do quite a bit of conference speaking and things like that, so those are the tools that I try to use hopefully the Lord willing to make some small positive contribution to the Christian school movement. I would also say though that one of the things we're trying to do is create an example at Briarwood that others at least can learn from not that it's the example but we certainly want to be a positive example of what can be done in a classroom. So that's one thing we're doing. The other thing is we've created what's called the smart, the Briarwood Smart School Initiative, I won't bore you with that except that SMART is an acronym that stands for several things but one of those is that our content is made available anywhere, anytime, anything by anyone that is smart and what that means is we have 
employed a, an online learning platform and our intent there is not only to bring course content to our campus but to take our own content we package and make it available online anywhere in the world for those who want it, particularly on mobile type devices, tablets, that kind of thing, smartphones, so those are some of the things that we're trying to do in order to be used of the Lord to be a blessing to others. We have a motto at the school that essentially says that, "We have been blessed in order to be a blessing." So that, that's really what we're hoping to do.

GP: That's great and is that content fairly much free to anybody who would access it or...?

BM: Some would be, some of it we'll certainly have to charge for...

GP: Mm hmm.

BM: ...to recoup our cost, otherwise our parents would be paying for it. [Chuckles]

GP: Sure.

BM: So you know of course that's what they pay tuition for. If it's a missionary school in XYZ country, an undeveloped count-undeveloped country we would probably just make that available so that's still under development as we roll some of that out.

GP: That's really neat. What role do you see parents playing in the modern school?

BM: Should be or do they?

GP: I guess it's assuming that they do play a role but, what role do you see them playing in your Christian school?

BM: I would view them as partners, again, I don't think that there's anything new. I think this would be true a couple years ago and probably will be true a hundred years from now. I think essentially they need to themselves and we need to view them as partners. We're part of a Christian community. We're sharing each other's gifts and talents and callings in order to, they help the entire community and so we wanna partnership. And that partnership means cooperation, learning from each other, correcting each other, repenting to each other as necessary, so really kind of a, godly, mature, partnership as we seek to educate the children. So, I mean that sounds very cliche-ish but there's a lot of content admitted in, you know, in those phrases and so you flush out what that means. That's certainly what we would expect of our parents. We, we require a new parent orientation for all parents coming into the school and we relay several things to them but one thing is what we commit what we will do for them and then we make some statements about what we expect of them back to the school. So, so that's probably the best answer I can give for that question.

GP: That's a great answer. If you don't mind, I'd like to ask one question just trailing off of that. At the beginning you kind of referenced history, you know this being an answer that would be effective 100 years from now and so forth. I wondered, do you really think that schooling and the view of, of parents 
being involved with schooling was the way that you're mentioning it now, let's say, fifty years ago? Twenty-five years ago?

BM: Do you mean, do I think that 100, you know, 25, 50 years ago that those same principles were in effect or still applied?

GP: Were they actually being utilized by most Christian schools that you're aware of?

BM: Well, yes and no. I mean, I think you know human beings are human beings. Families are families. If you go back and you read through your history, you read through the Old Testament, virtually every patriarchal family was, was dysfunctional to high degrees. [Chuckles] You know, so I, I, in that case I don't think there's anything new under the sun. I think the same issues arise, the same needs are there, the same principles apply and how they, how they work themselves out with various tools that might be deployed could be a little bit different. But I think the fundamental principles would apply 100 years ago and probably will be applying 100 years from now.

GP: $\mathrm{Mm} \mathrm{hmm}$. And you think that Christian schools about 50 years back were actually applying those principles fairly well?

BM: [Long pause]

GP: In your experience?

BM: Well you know, I don't think 50 years ago we had that many Christian schools until about the 60s and 70s other than secondary, we had some and certainly Catholic schools were way ahead of the Protestants in that regard.

GP: Mm hmm.

BM: Do I think they did? My guess is yes. My guess is that if you could talk to them, they would point out to all the areas that I didn't feel like it was sufficient.

GP: Mm hmm.

BM: And then they'd probably point out to where they weren't doing a good enough job or parents weren't being cooperative enough, you know that sort of thing.

GP: Mm hmm.

BM: So in that sense I'm not sure it would change fundamentally now I do think and again we tend to romanticize the past too much, I think and degrade the present more than is appropriate but I think it was probably fair to say that as a general rule in prior generations there was a greater tendency for the parents to assume the teacher and the school was correct and it was up to the child to respond accordingly. Whereas now I think too often there is a knee jerk reaction to jump to the defense of the student and then put the school on the defense and the school and the teacher must be wrong. So, I do 
think, if you talk to veteran teachers they will say that they've seen that shift take place. That's probably true because in general I think there's been that shift in culture. I also think there's been a general decrease in civility in conversation. If you listen to talk radio or talk television, it's, it's really not intelligent on the liberal or the conservative side. They talk over top of each other, they're not good at listening to each other, they're not learning from each other, they never admit that they could be wrong so that carries over into the situation sometimes with students and the school, its own staff and parents. So, yes, I think there's some change there but fundamentally I think it's essentially the same.

GP: Very good. Thank you. Are there any other thoughts on the need to transform education as it now stands, especially Christian education, that I might not have asked you about that you might like to comment on or share?

BM: Well just in general, and I've probably alluded to it, Christian education in my estimation is not about ascending the ladder, it is not about defending students, it's not even about fundamentally preparing students to defend themselves and their faith, it is about positively learning to take every thought captive to the obedience of Christ so that we might live as engaged, creative, redemptive people in culture where when people encounter us and our students, what they're hearing from us are positive solutions, positive responses. That doesn't mean we don't condemn sin where sin needs to be condemned but that's not the primary thing that they're hearing from us but what they're seeing and hearing is our engagement with the cultural mandate, we've given it genesis, being redeemed in Christ, recognizing that at the end of the age, God is gonna come and live with us on planet earth, we're not gonna be in heaven, he is going to be here. So here counts now, counts forever, and it's important so in light of that, I just think Christian schools need to quit saying so much about being against culture or preparing students to be protected again or from the culture as much as to engage the culture in a positive way. Let me give you kind of an example...

GP: Mm hmm.

BM: ...curiousness to why it is, and there may be some stuff out there that I'm not aware of so I will fully admit that but, I'm curious as to why it is that when Christians want to go and have a romantic dinner or whatever that nine times out of ten they have to go to the secular artist for songs on romance and love. Why aren't Christian artists writing songs on romance, love, and sex? Now, within marriage.

GP: Hmm. [Chuckles]

BM: Obviously.

GP: Amen.

BM: What, God created it, he created the family, he created marriage, he created romance, he created sex, and yet, it, if we wanna hear that kind of music, with a fault to other artists modern or older in order, for that music. Why is it that Christians are not at the forefront? And the fact that we're not is one reason we're so marginalized while not impacting culture. If all C.S. Lewis did was write books on 
apologetics he would not have had the impact that he did for having written books on literary construction and deconstruction, had he not written books on, with children's literature, et cetera. And I'm afraid that's a massive failure on the part of Christian community where we huddle in our villages as it were, metaphorically speaking, and when the world hears from us, it's when we're against something rather than when we've done something.

GP: Amen. That's a great point. Yeah, actually to speak to the point on sex I met, I'm going to speak with Danna Gresh. I don't know if you know her ministry but, Danna speaks in this area and I think really around the country about just purity especially from the female point of view for young women.

BM: Right.

GP: But, uh, her husband, Bob and she started a school called Grace Prep, it's in State College, PA and one of the taglines that Danna brings up is, "God loves sex more than you do. He created it." [Chuckles]

BM: [Chuckles] I just wish the Christian artist wouldn't feel like that in order for it to be a Christian song, a God-honoring song, it has to have God or Jesus in the lyrics. It doesn't.

GP: Mm hmm.

BM: So that's just a minor example of what I'm trying to communicate, I think.

GP: Sure. That's a great point. So, I'm gonna go off my questions for a minute here because you've intrigued me. I certainly agree with much of the way that you're talking if not all of it and just ask you a few points about Biblical integration, Biblical framework, how you look at that in your, the curriculum at your school from your point of view as an educator. How do we do that? As you were talking there...

BM: [Chuckles] you know, frankly, that's a hard one and it's hard because most faculty are not well trained theologically...

GP: Mm hmm.

BM: ... and you cannot give what you don't possess and so l'd say the vast majority of Christian teachers have always, have gone to public institutions, there are exceptions, but most of them have public schools, most of them have public universities, they go to churches that love Jesus but frankly most of the sermons are focused on either one of two things: being saved again even though $90 \%$ of the people in the entire congregation are already believers or sort of a narcissistic message that God is there to bless you. That this is about you, it's about your family, it's about your finances, it's about your relationships, it's about your job, it's about your children, et cetera and it isn't. And, so when that is, when they're receiving basically cotton candy from the sermon, from the pulpit and then basically had a secularized education, it's very difficult, even with the best of intentions for them to know how they're going to integrate AP Calculus with theology. I saw this played out when we were doing, we were doing a substantial training in the area and I saw this played out, I was in, we split them up in groups and gave them an assignment and I was standing in the back of one of the math groups and they were doing 
quadratic equations on the board and trying to figure out how they were going to draw a moral lesson from the Quadratic equations. [Chuckles] And when I realized what was going on, I realized what the problem is in many Christian schools, they're confusing moralizing with integration and that's not what it is. There is no moral lesson necessarily that can be drawn from the Quadratic equation, the point is, what, why, what is the origin of math and what is its purpose and how do we utilize it for that purpose? Well, for God's glory and to love our neighbors and to serve our community and that is hard for the teachers to get beyond some generalized principle. I'll give you an example. I'll talk to teachers at interviews and, interviewing them, let's say they're gonna be history teacher. I'll ask them a question like this, I'll say, "Give me two examples of very specific Biblical integration in history; however, here's two things you cannot talk about. You cannot talk about American history at all. I don't wanna hear about pilgrims, puritans, or Christian heritage. Talk about Japanese history, the Buddhists if you want. And you cannot talk about God being sovereign over history, that's a given, we know that, fine, that will take two days to talk about then what are you gonna do for the other eight months? So, you take those two things off the table; explain to me a Christian philosophy of history." $99.9 \%$ of the time, I get a blank stare. I get more blank stares when I do the same thing with math except I say, "You cannot say that God is the creator of math, that's a given, and you cannot say that numbers are orderly because God is orderly, that's a given. That's a thirty minute discussion with your students, then what? So, beyond those two things, what is a Biblical philosophy of mathematics?" And again, more often than not, I tend to get a blank stare. And so, our challenge is to provide the teachers enough theology and then to help them take that theology and transfer it to subject content and application to students lives and learning and that requires a lot of reading, a lot of work, and a lot of practice along with some humility that says, "We don't have all the answers and in fact sometimes we could be wrong." So, [Chuckles] you know and I will say one more thing and then I'll really hang myself...

GP: Hmm. [Chuckles]

BM: ...and that is, in fact I'm reading Tim Keller's book, "Generous Justice" which is marvelous. One of the things that I think particularly in conservative Christian circles that we tend to make the mistake of doing is confusing and identifying conservative, political ideology with Biblical theology and they're not one in the same. Sometimes they are, sometimes there's not, they're not. Sometimes liberal ideology will conform more specifically to Biblical theology than the other way around so what we're trying to get our teachers to do is not think like a conservative or a liberal but to think like a Biblically literate, thoughtful Christian on all the issues. So, that, those in my mind are the real challenges. It's the only fair thing to do for students also.

GP: That's great. It's amazing some of the things, many of the things that you've said and some in different words, some in the same words are so close to what I've already interviewed and I'm looking forward to it, you're uh, my second interview. D Bruce Lockerbie happened to be my first and I've got about ten more that I'm gonna be doing so I'm really excited about God teaching me along this process and really thankful for what you shared, a lot of wisdom there and I hope I asked questions that were fair and, and uh, you were feeling comfortable to answer, and so, thank you. 
BM: No, listen, I admire what you're doing and I hope I didn't get on a soap box, but I love Christian education, I love Christian teachers, I love what the movement can and could do and so my passion behind this is because I believe so deeply in it. I sometimes get a bit disappointed when I look around and see what we're doing versus what we could be doing but uh, I love the movement; I love what the Lord has done, is doing, and can do with it, so...

GP: That's great. Well, I don't wanna keep you all day long. I really do appreciate your giving me the time to talk today and certainly introducing me to ooVoo, that looks like a great technology and...

BM: Trust me, it didn't work today but it really is great. It, it, it's better than Skype, I almost always have more trouble with Skype than I do ooVoo and I think ooVoo is Skype on steroids but I'm not sure what happened today but normally it's great so...[Chuckles]

GP: Yeah, it looks wonderful. I'm definitely gonna be using it, and I already introduced it to a few people just to say, "Take a look at this." So...

BM: Listen, apart from your work, feel free to call anytime if you're ever in the area, let me know. I'll buy you lunch so just, if I can, if Briarwood can ever be helpful, brother, we are more than happy to try to be of service.

GP: Thank you so much, I really appreciate it. I really do.

BM: Okay, well the Lord bless and let me know if I can be of help.

GP: Okay, thanks Doctor Mosbacker.

BM: Okay, thank you.

GP: Have a great day. Bye.

BM: Okay, you too. Alright, bye-bye. 
Title: Phone interview with Dr. Randy Ross

Date/Time Recorded: 4/11/2011 1:34:54 PM

Record time: 0:37:13

GP: Okay, so I'm here today with Doctor Randy Ross and Dr. Ross if you could just talk a little bit about your title and what you're responsibilities with ACSI are...?

RR: Okay, I am currently serving as the Regional Director for ACSI and the region that I serve is the Ohio River Valley Region which was divided off from the Mid America Region in 1999, so when I first began as a Regional Director for five years I was the Mid America Regional Director. For the past, what would that be, eleven years? Ten years? Twelve years? The past twelve years I have been the Regional Director for the Ohio River Valley Region which is Ohio, Kentucky, and West Virginia.

GP: Okay. Very good. Alright, I talked a little bit before we turned the recorder on about what I'm interested in gaining and what I wanna do is just launch into question number one here and as you answer, if you feel like you can answer really succinctly, great, if you feel like you wanna maybe philosophize for me a little bit that would be great too and we can kind of wander around kind of a conversation more than point by point. What are the key elements, Randy that you believe should set Christian schooling apart from secular schooling especially here in the 21st century?

RR: [Clears throat] Excuse me. I believe the primary distinctive that Christian school education should have would be in the name itself, it should be distinctively Christian. And if it's gonna be distinctively Christian then we're talking about the centrality of Jesus Christ and we're talking about the centrality, Jesus Christ as the living word of God and then the centrality of the Bible as the written word of God. So to me those would be the primary distinctive and those should be reflected in everything that the Christian school does.

GP: Mm hmm. And do you see it, some people talk about Biblical integration, some people talk about seeing things through a Biblical framework, is there a specific way you like to talk about that when you think about Christian schooling?

RR: Well if you're gonna be distinctively Christian, first of all, I think you have to recognize that God is the author of all truth, if anything is truth it's because God has established it to be true and of course that's debatable in the secular world because they don't' really want to recognize one primary source of truth. And so, if that, if that is accepted as a premise then it's going to be reflected in all the things that a Christian school does because we should be in the business of truth, you know, as a Christian school and to me that's really what Biblical integration is, is, it's that integration of truth into the very things that a school practices, not only in education but also in spiritual formation and also in athletics and in the arts and sciences so basically everything that we do. 
GP: Great, thank you. Are there specific needs for students in this generation that stand out to you as unique or even different from past generations that you've witnessed in Christian schooling?

RR: Well, that's kind of a trick question. [Laughs]

GP: [Laughs]

RR: Because, uh, you know I think our needs are really basic no matter what generation that you live in. I think cultures change and I think that's what has happened is that our culture has changed and when the culture changes then you have stronger emphasis on maybe one or two or three areas of needs that maybe a previous culture or generation and so on did not have.

GP: Mm hmm.

RR: And so if you believe the research you know, and we have people like George Barna and we also have Josh McDowell who quotes a lot of George Barna... [Chuckles]

GP: Mm hmm.

RR: ...telling us that you know a primary need in today's culture is for relationships, meaningful relationships, relationships whether its confident, mutual trust, so on and that is something that is pretty significant, you know, as far as today's culture and generation.

GP: That's great, so specifically relationships stand out to you as one of the defining needs of this generation?

RR: That's correct but obviously that's not a new need, I mean...

GP: Yeah.

RR: ...if you go to Scripture, you know, whether it's Old Testament or New Testament, you know, the two primary commandments, you know are: Love the Lord your God, and love your neighbor as yourself. And those are about relationships. [Chuckles]

GP: Right.

RR: So, it's a basic human need, it's just that the emphasis today in our culture is on those meaningful relationships and making sure that we have an emphasis on those.

GP: Very good. Are there two or three necessary changes, alterations that you believe teachers in the 21st century Christian school must make in order to reach students effectively?

RR: well, if we go by what I just previously said, you know, if you have teachers that are not able to build relationships with students, they are not going to be effective because it's not just communication the subject matter, it's building relationship with that student and especially in the Christian school that is very significant that you need to have relationships as something that is primary because the only thing 
that steps out into eternity are people. You know, it's not text books, it's not knowledge, you know, it's not degrees, it's not honors or trophies or whatever, you know, what steps into eternity is people. And so, the Christian school teacher has a responsibility to build relationships and if they're not gonna be effective in doing that, they really shouldn't be in teaching and unfortunately I think we have some teachers [Chuckles] that are not real effective in that arena.

GP: Mm hmm.

RR: And as a result, it really undermines having an effective relationship with students. So that would be one area, uh, the second area, obviously we live in the age of technology and so I think we have to make use of technology and our students are very adept usually more adept in technology than the teachers and the leaders, you know, as far as Christian schools are concerned. And so there are times when we can actually learn from them and I think that we should. I think it should be a dialogue, it should not be a lecture and we need to make sure that we're incorporating technology into what we do. And, I mean I think those are two primary things, you know, relationships and technology. I think staying current as far as what works and what doesn't work, I think is as well, is very important, a very important thing for us to do. There's a lot more research based, there's not theories but uh, more research based truth that is coming out as far as what makes an effective teacher, you know, how do we, how do we better enable students to learn, you know, in the day and age in which we live in. So i think we have to pay attention to those things because that can be a source of truth for us to use and become more effective in the learning process.

GP: Very good, thank you. Well stemming off your technology point, uh, what technology needs do you see as most essential to be taught in the 21st century Christian school? Maybe there are two or three that stand out to you as far as methods, things that we should teach when it comes to technology.

RR: Well I think you have to recognize that technology is everywhere, I mean, in every, I mean cell phones are basically computers, computers nowadays.

GP: Definitely.

RR: And so you know we can't ignore that and not only that [Clears throat] it's not just recognizing that technology is a huge part of our culture it's also having the proper use of that technology because like anything else, you know, tools can be used properly or they can be used improperly, they can be used for good, they can be used for evil and so we have to teach discernment to the students and the proper use of the technology. [Clears throat] And once again they can actually teach us because sometimes they have better access to things that they know are not appropriate or not right or uh, are not something that a Christian student, you know, should be using or have as a part of our life and so on. [Clears throat] And so I think, once again having the dialogue in that particular area is very, very helpful. Other than that, you know, l'd say you know any chance you have to use technology you should be doing it in the Christian school. If there is somebody as a teacher who is resisting that then they need to have a willingness to be taught or to be coached in this area and actually have as a goal to start using, you know, technology as far as what they are doing. So I'm talking about, you know, smart boards, I'm 
talking about social media, I'm talking about a lot of, some of those aspects as far as technology is concerned. Those can all be tools.

GP: Mm hmm. Good. Well you've mentioned students teaching us and we know if we look at learning pyramids that have been put together and so forth, that lecture is actually the least memorable and teaching others is actually the most memorable up to $90 \%$ of what people teach others they tend to remember themselves. Do you think that this is a key issue that divides teachers and students here in the 21st century here for instance teachers that are resistant to give up the reigns somewhat to allow students to maybe do some of the not instruction specifically but maybe uh, helping to lead a little bit in the classroom?

RR: Well just like in leadership where they have proven that team leadership is the most effective style of leadership, there are other styles, you know, the top on down style, the autocratic style, the Lesley Fair style, there are a lot of other styles but the most effective is the team leadership style and I think it carries over into the classroom too where the most effective teaching would more of a team leadership, you know, and as the child matures, you know, and becomes more responsible then I think we have to give them an opportunity to succeed or fail based upon assuming more responsibilities as they mature and get older. And I think a lot of times it's, it's the mental block where the teacher feels like, you know, "I'm the dispenser of knowledge and you are the receiver of that knowledge and that's how it works, that's the formula." And I think that's not the formula. [Chuckles]

GP: [Chuckles]

RR: And I think that we have to recognize that cooperative learning can be very appropriate giving the students an opportunity to lead in certain areas, having oral [clear throat], oral reports, working on projects together, those are all very effective and they probably learn more by doing those kind of things then they would in a class where you're primarily dependent on lecture or worksheets or something like that.

GP: Very good. [Clears throat] Are there specific steps, Randy, that you feel must be taken quickly in many Christian schools to bring about the type of environment you've been talking about as beneficial for 21st century Christian school students?

RR: Well there's always that willingness to learn yourself, i mean, every single one of us should be enrolled in the life long school of learning, once you stop learning you're dead. You know, and so, you know, you need to make sure that you're open to learning and instruction and teaching yourself and I use a little cycle when I talk about this, I call it the Learning Cycle but it could be called the Gross Cycle or the Maturity Cycle or the Perfecting Process or the Transformation Cycle. There are a lot of things you could call it but all learning should lead to growth, all growth should lead to improvement, I'm sorry let me back up. All learning should lead to change but all change should lead to improvement not just change for change sake...

GP: Mm hmm. 
RR: ...all improvement should lead to growth and that then, that growth encourages more learning and change, improvement and growth. So it's a cycle...

GP: Mm hmm.

RR: ...you know, continuous cycle that should be going on every single day. And that's not just in the classroom that also in the life of the teacher, the life of the administrator, the life of the parents, to me that's the Biblical model, it's called a Transforming Process in Scripture, it's also called a Perfecting Process in different passages in the Bible. And we will never become complete or whole or mature until we see Jesus face to face.

GP: Mm hmm.

RR: And yet, everyday we're supposed to become more like Christ and that's in all areas in which God has made us. You know, we're a reflection of God because we're made in his image and we're made to be spiritual creatures but we're also made to be academic or mental and social, as well as physical beings. So, it's making sure that learning is taking place in all of those areas.

GP: That's great, thanks for sharing that learning cycle with me.

RR: Sure.

GP: Did you, uh, did you come up with that somewhat yourself or is that something...?

RR: Well I think I just put it into a little diagram. I like diagrams. [Laughs] And so having the cycle is a picture and people remember pictures and so I've shown that on a number of occasions in different settings and people like, really identify with that and realize that we all have to be, we have to buy into that, and we have to be enrolled in that lifelong school of learning. And, so that's really the point. Once we stop, you know, we shouldn't, we should never stop learning.

GP: Yeah.

RR: And so, it doesn't mean that we have to go to graduate school all the time, it does mean that every day we should be learning a little bit more so we become more like Christ on a daily basis.

GP: That's great. [Clears throat] If you're involved in a hiring process for a 21st century Christian school, what qualities or characteristics would you look for in applicants to provide students the type of education you've been talking about?

RR: The applicants for teaching correct?

GP: Yes.

RR: Okay. [Clears throat] Well first of all they have to know their subject matter, you know, and, and certainly you know having questions that address their subject matter is important but because we're talking about a Christian school, what is happening in their life as far as spiritual growth and how they're 
maturing as a believer in Christ? What is their relationship with Jesus Christ? What is their relationship with God? What is their relationship with fellow believers? You know, I wanna see that they're actively pursuing, you know, a process in which they can grow in each of those areas. So, it's not just a professional interview that is taking place it's also a spiritual and very personal interview that's taking place because students will catch more than they learn and they're gonna catch things from their teacher by the life that that teacher lives before them on a daily basis. And so it's what is caught, not just what is taught, you know, that becomes very essential, very important. So I would have a list of questions that say, okay, "well when is the last time that you actually prayed for an individual student? When's the last time that you talked to an individual student about their eternal destiny? When is, when have you personally gone to an event outside of school that one of your students was participating in?" You know, just a number of different questions that maybe would catch them a little off guard but also tell me whether they're really interested in their students or they're just there to teach the subject matter.

GP: Mm hmm.

RR: So I think not only that expertise but also, which includes their educational background but also that spiritual element that says, "You know, I'm willing to come alongside students and have a ministry in their life, not just teach them the subject matter." And they're both important but because we are Christian schools they work together.

GP: Very good.

RR: So I would even give them situations and have them respond to situations and that's gonna tell me, you know, what they would do.

GP: Mm hmm.

RR: And then what they actually have done. [Laughs]

GP: Very good. Can you tell me about a time that you felt most positive about your work and as a Christian educator in that your goals and values in Christian education were being strongly met? Is there a specific time that stands out?

RR: Well, I think having the opportunity to share one on one in a mentoring relationship is a pretty powerful teaching tool and that works for Regional Director too.

GP: Mm hmm.

RR: So, it's probably four or five years ago that I made a personal decision to identify some administrators in my region that I wanted to have a one on one mentoring relationship with. And so I have probably identified one person each year for the last four or five years and set up appointments with them, ask their permission to maybe have some kind of a mentoring relationship or kind of just pour myself as much as I can into their lives and you know, have them ask questions and so on but take 
time and set it aside and just kind of build into their life one on one. That was something that was presented to me as a challenge by what someone else was doing.

GP: Mm hmm.

RR: And as you look back on your life you know that's what you wanna say is that, "I made a difference in that one life or that life this year or that year." and so on. So that's been a pretty powerful more, more recent impact as far as what I see as effective communication with a fellow educator and administrator and leader and so on. And so, I would say that would jump to the front of my mind as far as something recent.

GP: That's great. [Clears throat] Are there specific situations, people, or events that have shaped, helped to shape the way that you view Christian education and the way you like to relate with students, parents, colleagues?

RR: Well there are a number of [Laughs] I mean, some of my highest points and some of my lowest points and yet God has taught me through both of those kinds of situations and also people who took the time to pour into my life, you know, and have an impact on me, so it just depends on what year we're talking about because, you know, that never stops either and that shouldn't ever stop. You're always looking for people to have an impact on what you do and, you know, help you to be more effective in what you're doing and so on. So I can go back you know 35-40 years ago all the way up to, you know, this past year and name people who have had an impact on the way I think, on the way I do things, and so on as far as Christian school education.

GP: Are, are there any...?

RR: There, there are milestones I think to in a person's history.

GP: Mm hmm.

RR: So I could go back and unfortunately some of my lowest points are some of the times when I learned the most. And I say unfortunately because afterwards you say well that was very fortunate, it was not unfortunate. [Chuckles] So God has his, had his design on that happening to me because he wanted to get my attention so that he could teach me something very valuable, something very important and significant.

GP: Sure. Well if, if I could maybe ask a question on top of that then based on what you just said, is there a, a specific high point or a specific low point that you'd be willing to share here on tape that uh, might help me to see more of what shaped your view, your current view of education, Christian education?

RR: Well, you know I think probably the low point and I even have the file in my files here that talks about the crash of 91 and I go back to 1991 it was probably my low point. I was an administrator for a school and when I went there, of course they didn't tell me everything, and that's not unusual. [Laughs]

GP: [Chuckles] 
RR: And so my first two years, it was like you know, getting all the skeletons out of the closet so that I knew what I was dealing with and so that beginning of that third year, you know, we started lining up all the things that needed to be done and so on. And we had, I had to let a business administrator go who was hiding notices from the government that we were not paying our taxes because he thought we didn't have the cash, you know, to pay those taxes and I hired a new person that I felt I could trust and she had just told me that at the end of the month she was going to leave. She couldn't handle the financial pressure. So there were some serious financial difficulties that we were dealing with the school and I won't go into detail but I saw all of that coming back on me. It was nice to be able to share that with somebody else but we had cut back in staff as well and so I was doing the development as well as being the superintendent and now I saw the business administrator's responsibilities coming back on me and so I crashed. You know, and in that crashing it gave me an opportunity to see how God brought people into my life at that time which started with my school board. I will always remember, you know, being at a meeting, a prayer meeting before one of our board meetings where they just gathered around me and laid hands on me and prayed for me as superintendent. And, it will always be a picture in my mind, I will never forget that.

GP: Mm hmm.

RR: I had my pastor at the time, come alongside of me and he said, "Randy, you have to go forward with both feet. The foot of faith and the foot of responsibility." And I will never forget that, and that has been kind of a launching pad for me to be able to share with many others that you've gotta go forward with both feet. You know, it's not just faith but it's also responsibility. It's not just responsibility but it's also faith. You have to go forward with both feet, so there's that balance of faith and responsibility and people have a tendency to line up on one side or the other. You know, I'm, some will be strong on the side of faith and weaker on the side of responsibility and then the reverse is true, they'll be stronger on the side of responsibility and weaker on the side of faith. And it's gotta be both and the verse that the Lord gave me was, Psalm 37:4, I'm sorry, 37:3, and it says, "Trust in the Lord with the foot of faith and do good with the foot of responsibility." And then the whole side of, well the whole book of Galatians and James where it says, "Show me your faith by your works." And it's the whole idea of faith and works together that God wanted to use in your life and then you have to go forward, you know, doing that. So that would be the low point, you know, as far as the high point um, high point, uh, several high points usually dealing with seeing major problems solved and there are a number of those. So that there were at different times something that took place where I would see those high points and realize, you know, I don't know if you want me to get more specific than that.

GP: No, that's, that's ok, that's great.

RR: Okay.

GP: Good stuff. Thank you for sharing that.

RR: Sure. 
GP: You've talked quite a bit about different ideas, maybe methods for 21st century Christian schooling that you believe must come about, how can your methods for adapting the needs of the 21st century Christian school be brought into the methodologies of our current school teachers? Are there two or three ways that you believe if you were to put it together that could be brought out to our teachers in Christian schools right now?

RR: Well, I think one thing is the initiative [Clears throat] that we're now planning as far as a change in professional development, how we deliver professional development to the teachers and the staff in the Christian school. We have evaluated conventions and the conventions have, have been with us since the beginning of ACSI back in 1978 and it's certainly been effective and it's been good but I think because of the culture that we're in today, we are seeing a decline in attendance at conventions, in conferences and even though there was some good dynamics taking place you know in those schools were making a commitment to go maybe once every two years or once every three years or not bring in their entire staff because they were dealing with the increase of cost and it wasn't the cost of the conference or the convention itself, it was the cost of travel, meals, and lodging in order to get there, stay there, and provide that for all of their teachers.

GP: Mm hmm.

RR: Especially among the larger schools we were seeing that becoming true. And so we just felt, you know here's this, you know if you do the research and you look at these graphs and they show you what is happening as far as the decline, you come to the point where you say, you know, "Obviously it's not working. There needs to be a change and so with the advance of technology and all that we can do as far as the area of technology, we're not only going to a new approach as far as [Clears throat] what we call the Event itself which would be, you know, people actually coming together over a two day period but making use of technology and you can have a satellite broadcast and have one site where you can bring in some major hitters, some really top people in education in the Christian schools, even Christian leaders, you know, from around the country that normally you would never have, ever at at a convention. And bring those to one site and then have them broadcast to remote sites by use of the satellite technology that we have. So that's the event and then since professional development is not just an event to process then the process becomes twenty-four seven, three sixty-five, professional development that can be recorded by video or by audio or however the most effective way is to record that by use of technology and then have a virtual library or archive that is available to the schools that they can use 7 days a week, 24 hours a day, 365 days a year at their discretion and at their leisure and bring them some very good professional development by use of technology once again that can be recorded and then accessed through a portal that ACSI will make available to the schools. And so I see that as a step in the right direction and something that could be more appropriate in the culture in which we live today as far as the 21st century and maybe become more of a leader in this area and what a lot of other schools are happening to do in education. So, I, I see that, you know, I see that as well as the addition of you know, online learning. I think that's gonna start playing more of a role as far as schools actually being able to offer more to their students because they don't have to do it all themselves. They can have access to online learning through different tools and organizations and 
options that are out there for them and so on. SO that would be one area, as an example, of what we need to do currently.

GP: Mm hmm. Very good. Well we've talked quite a bit about teachers and administrators, what role do you see parents needing to play here in the 21st century Christian school? Is that role transforming, changing in your opinion at all?

RR: Well, once again, I don't think the role has changed but the methodology certainly can change. I think parents have to become more in tune to what is happening in the culture [Clears throat] You know, God's word and God's principles don't change and yet because of the change in the culture we have to become more adept to, on what's gonna work with, you know, the current generation of students. And parents have to keep up too. And I don't think that churches have done a good job of staying current in this area and I don't think that schools, Christian schools have done a good job. So somehow there has to be a process where parents are actually being trained. And I think it has to be shared between the church and the Christian school as far as where that trainings going to take place. Parents are not being taught how to be parents to the current generation and if it is offered, then parents aren't going for some reason, so we have to figure out, okay, "How can we do this? You know? What's going to be effective? I don't think the role has changed but I think the methodology because, you know, we say that we are in partnership with the parents, are we really? Or are the parents just dumping their kids off and expecting the Christian school to take care of the process of training and educating their child? And so, we have to be careful that it really is a partnership and not just one sided.

GP: Mm hmm.

RR: And in order for that to happen parents have to know what can be effective for them to do in their role. SO their role is the same but the methodology changes.

GP: Okay, well I've asked you quite a few questions, you've answered very well. Thank you for all of your very clear and great answers on each. Are there any thoughts on the need to transform education for the Christian school in the 21st century that I've not asked you about that you would like to share or any books that you've read that you would recommend my taking a look at?

RR: Well you would put me on the spot as far as books. [Laughs]

GP: You always have some at the convention I know, you're always... [Chuckles]

RR: Yeah, um, you know there, I would say if you're gonna look at books, you know, and there's so much out there that to me one of the first qualifiers would be that it's research based.

GP: $\mathrm{Mm} \mathrm{hmm}$.

RR: You know, it should be based on research and what is true and what, what is working now. What is true of the culture right now and so being a research based I think is very important. I think, you know, as, I think we can learn from education in general and I don't think we should be afraid of that because 
there's a lot of truth out there in, in public education and so on and God is the author of that truth just like he is as far as what we are doing. So even though they don't give credit or recognition you know to God you know for that truth, if it's true, it's, it's you know, God's the author of it and so we shouldn't be afraid of it. We just need to recognize it for what it is. So I'd say those would be some things that I would look for as far as books are concerned. I think we do carry some books that have, that have been wonderful additions you know to ACSI, you know, I'm thinking of one that I had recommended to people on um, developing Christian character. I'm trying to think of the name of the book or the author. I should probably pull out a catalogue or something like that. [Chuckles]

GP: [Laughs] Yeah.

RR: I think it's cultivating Christian character something like that but there are a number of resources that I have recommended you know that really can be very helpful to teachers today and we try to do a good job on going through and making sure that these are what we want to be offering the teachers and so on. Yeah, "Cultivating Christian Character" is one of those that I mentioned but there's a lot of others too. We've actually done a little with ASCD, Association for Supervision in Curriculum Development, they have come out with things like classroom instruction that works or the qualities of effective teachers, what works in schools, and you know that type of thing.

GP: Mm hmm.

RR: So I think that's been helpful too because those are research based books. I think one of the best books I've read in the last five years would be "Transforming Children into Spiritual Champions" by George Barna. He of course is a guru in research but he's also very biblical and it's just a powerful book for anybody who's a Christian to read: parent, pastor, you know, Christian school teacher, administrator, and so on. And so that is certainly one that is on my top five lists I think but there are others as well.

GP: Very good. Well thanks so much for taking the time to talk to me today and like I said your answers are great. I've interviewed quite a few people at this point and I can tell you that some of the answers that you gave are similar threads running through the research.

RR: Oh I'm sure. 
Title: Phone interview with Jeff Woodcock

Date/Time Recorded: 4/12/2011 1:35:47 PM

Record time: 0:35:59

GP: There, okay so I'm here with Mr. Jeff Woodcock today and Jeff if you could tell me a little bit about your title and what position you have at the school you work with.

JW: Yeah, I'm headmaster, I'm founding headmaster at Oaks Christian School in Westlake Village, California.

GP: Okay. Thank you. And Jeff, are you a Cedarville Alumni? Did I hear that correctly?

JW: I am, yeah, I am.

GP: Okay. And is that undergrad?

JW: Yeah, it was undergrad, right.

GP: Okay and where did you graduate schooling?

JW: I did a Masters in Science and Education at SUNY Fredonia.

GP: Alright, so you've gone coast to coast basically.

JW: [Chuckles] Yeah. I did Doctoral work at UCLA, but I never wrote my dissertation.

GP: Alright. Well, I'm learning a little bit not about the doctoral dissertation but just about the masters interviews and the thesis that will come about here so thanks for taking the time today and I'll launch right in with the first question. What are the key elements that you believe, Jeff, should set Christian schooling apart from secular schooling especially in the 21st century?

JW: Well, I think one of the elements in my mind is Christian teachers. I think it's important that we have a unyielding faith in Christ and that certainly sets you apart from public schools and it's the one unifying factor that brings the staff together for a common vision and that's a spiritual vision in addition to the other vision that schools support so, I think that's a critical element. I think in our particular environment we have an open policy with respect to students meaning that we don't just accept Christian students into the school but that, that particular distinction varies from Christian school to Christian school depending on you know there, if they're sponsored by a church or have a specific policy regarding that and I don't think there's a right or wrong answer there but I think that one of the common elements is that you need to know what your mission is so that it's distinct and so that you know, you know, what you're striving for. Third element in my view is a coherent and well thought through mission statement. We're very mission driven at our school and we have created a mission that 
everything revolves around and uh, our mission to quote it is, "Dedicated to Christ in the pursuit of academic excellence, artistic expression, and athletic distinction, and growing in knowledge and wisdom through God's abundant grace." So we have three pillars all revolving around being dedicated to Christ in our three piers: our academic excellence, artistic expression, and athletic distinction. And so, all these things become important elements of who we are. We also have a very specific vision statement, "Minds for leadership, hearts for service" and so, so we work very diligently on developing strong leadership and also kids that are interested in serving and giving back. So those are important things. So I just think it's important to know who you serve, that you're bound together by a common element of Christian teachers and Christian employees, and that you have a clear cut mission and you, you, you are laser-beam focused on achieving your mission. Okay. There are other things that I'm sure we'll get into as you continue to ask questions but those are some key elements that strike me.

GP: Great. Thank you. Jeff, what specific needs of students in this generation stand out to you as unique or even different from past generations you've worked with?

JW: Well that's an interesting question because I'm; I'm probably on the older end of people you've talked to. I'm 60 so, I have been in the business since my early twenties and I, you know, I don't think there's anything new under the sun per say, but I think what's changed is culture's acceptance of things that perhaps were not so publically accepted years ago and the media is certainly different than it was when I was in the educational business was younger. So the influence of media and I'm talking about all electronic devices and the computer, computers and access to, you know, a hand-held devices and telephones and all those things. So, it's way different in that regard and because of it, you know, there's, there's a certain sense that in order to be current or up-to-date, it's probably good to employ use of these devices and things as much as possible to some extent but I don't, I still don't think you can replace the teacher and, and uh, the uh, the mode of education and even the delivery platform of it's changing but in terms of coming back to, you know the guidance of the teacher, I think that's still important. Although I will contradict myself in some ways because I also believe the fastest growing segment of education today is online education, and we as a school are launching an online school in conjunction with Oaks. We've got quite a brand in our name because we're pretty well known and so we're, we're gonna leverage that brand and launching an online school to reach a whole new segment of the population as well.

GP: $\mathrm{Mm} \mathrm{hmm}$. Great. And can you tell me a little bit about how you see that online school through Oaks Christian being leveraged? Is that something that's more regional or are you gonna go global at the higher end?

JW: We, we are, we, we have a website, we have developed in conjunction with some partners, I don't know what the total number is right now but close to in the forties and we're gonna expand it to the seventies and eighties number of courses that we're developing. And we are doing a media campaign primarily internet focused, a pretty sophisticated marketing plan, we have now generated, and I'm saying with this while it's being launched, I mean it's, the whole, this online school's been launched probably for at least a few weeks in terms of being online and we've already received hits from the 
seven to ten countries around the world that had all fifty States in the United States and several thousands of hits on our website. So, you know, we're, our goal is to launch it worldwide and see what happens but we're also fully intending to have effects on our local population closest to us, you know, and concentric circles around the school and branching there out. So we think that we'll be most effective to those in our regional area but we, we do have, have vision to have a worldwide audience.

GP: Okay, very good. Well maybe keying off of that, what technological needs do you see as most essential to be taught and used by 21st century Christian school students?

JW: Well I think it's, you take for granted that they have to have computer skills, that's a requisite and in fact I see us changing what we're offering in computer courses so that probably we're gonna move away from basic technology courses because, where just the requisite kids are gonna have that when they come, they come to us. But, I think you know in terms of classroom, smart boards are certainly, you know, we're certainly trying to fill our classrooms with smart boards as much as possible. We're adding to them, they're not inexpensive but and there's types of ways you can get at that with lower cost and so forth but we're reviewing the whole textbook option thing and we're wondering, we haven't yet moved to having all online or device operated text books but that's something that I, I think is gonna come. And as the cost of the education has continued to rise I think that's gonna be something that's gonna happen but we haven't moved to that fully yet. We're not a laptop school per say meaning that all kids get laptops and are expected to use laptops. A number of our students use laptops and other devices, but we're not a full on laptop school at this point, and I don't know that we will be cause I think even the laptop world is changing for iPads and other type of devices, so you know, we haven't moved in one direction or another per say that way yet.

GP: Could you identify two or three necessary changes that you believe teachers must make to reach 21st century Christian school students?

JW: Well, you know, I, I, I think they still need to maintain their commitment to Christ, so that being a given, I would look maybe at some other practical kinds of things. I just...let me; let me think about that for a minute.

GP: Sure.

JW: I guess they need to be open to technological advances as well that would be one thing and that's a big bucket so that you can put whatever you want in that bucket but technology savvy would be important. I still think they need to be experts in their field but they need to be able to employ uses of technology to help kids and pursue their own learning as well and help them to be able to have the resources that they can utilize themselves to become self-motivated learners and triers. You know, I don't really have a good answer for you, I guess, I don't know.

GP: That's alright. So really what's standing out to you it seems is the ability for teachers to have a tech savvy, as you said and... 
JW: Well, to use the things that are available for technology that, you know, when the history teacher is doing a lesson on, you know, European history, you know, they can bring in video clips of actually clips from Europe from example very easily into the classroom or you name whatever it is. I was in a school in San Diego and on an accreditation visit recently this is a school, a charter school, a public school and it was for an accreditation that I served on the committee of and they reach out to underprivileged kids, they have to be lower socio-economic backgrounds whose parents have never gone to college and these kids through what's going on at the school are all taking lab, they're all taking, they have to take 8 AP and Honors classes before they graduate from high school and these are very disadvantaged kids. They have very high standards and because of budgetary issues in the school they're not able to do a lot of live labs in Science but they've developed a way of doing lab sciences through use of technology on the internet and to be able to simulate labs within the classroom, this is very life-like stuff. So, that's an example of ways that we've got to be able to employ uses of technology to integrate into the classroom and there's a lot of good things out there that you can do in that way.

GP: Very good. Do you think there are any key issues that most divide students and teachers here in the 21st century? Anything that stands out to you?

JW: Well I think the culture is changing so rapidly that, you know, even in Christian schools, and of course, we're a West coast Christian school in California and there's a lot of influence of the world in our school. A lot of my parents are involved in the film industry and studios and producers and directors and actors and actresses and so, you know, the influence of the world is huge and you know we're trying to have an influence and so forth. I, I think, you know, the effects of the culture in what students are hearing in terms of what's accepting, acceptable in the culture, I, I, I think there's you know, I mean that the influence is so pervasive that I think that there can be a difference between how kids view certain cultural issues and how faculty and staff view them but I even find that amongst my staff and faculty, the younger ones might have different views than those that are a little bit more, a little bit older and so forth. So those are some issues that I think we're facing today.

GP: Okay, what specific steps do you feel must be taken to bring about the sort of learning environment that you believe is most beneficial for 21st century Christian school students?

JW: Repeat that question again.

GP: Sure.

JW: What, what...what steps?

GP: Yes. What steps can be taken to quickly bring about, in any Christian school really, the type of environment you believe is most beneficial for 21st century students?

JW: Well I think professional development is really important and I think for your faculty and staff you have to invest in their professional ongoing development, be it, you know, whatever the delivery systems are out there you can train and develop in that regard and help them to become familiar with 
those kinds of things but I think they need to continue their professional development within their subject areas so that they're subject area experts and that they're employing, you know, research based approaches to education and so forth. So, I think a lot of it has to do with, with uh, training programs within the school and I think you need to invest in that and you have to be, I think Christian schools have to, you know, I know a lot of them are compressed in their budgets and the economics and so forth but if they're gonna be really equipping their students for this century, it's vital that teachers and so forth are trained in what, what's going on and keep up with stuff both in their subject area or content areas as well as the approaches to education. And there's a lot of good stuff out there.

GP: Mm hmm. You mentioned research based materials, for you, what does that encompass? Are there some things that you could point us to in terms of research that you know is viable, regularly good for your school, et cetera?

JW: You got me there.

GP: That's alright. I was just keying in on that term because research based came up with another interview I had and you know certainly see the benefit of that and just wondered if there were some particular places that you were going as a leader to pull different types of educational research.

JW: Well, let, that's why I say a lot of the conferences and professional development seminars we've gone to and presentations that are being made in subject area, content areas, and so forth, a lot of them are research based. You know, I mean, I just can't quote for you off the top of my head a lot of these studies but that's what I'm seeing in a lot of the, the current professional growth areas.

GP: Okay, very good. Jeff, when you're involved in a hiring process, what particular qualities or characteristics do you look for in applicants for teaching positions...?

JW: Two or three main things. Three main things. I've done a little bit of research on teacher quality...

GP: Mm hmm.

JW: ...and the things seem to boil down to three major areas: background and knowledge of your subject area, so I want to make sure they're content experts, they generally have majors in their field of study so if they're teaching science, that they're a science major and even more specifically is there a biology teacher they're trained in biology, chemistry or whatever it is. So that their, knowledge and background subject area. Number two is didactic skills, that is, do they know how to teach? And you know teaching methodologies have been doing through a teacher ed. program so they know how to teach. Then the third area is almost un-trainable but it is something that I think is the most important, that is relational skills with the students; that is the ability to relate and, and make a difference with students, have a good repo ire with students. I have found in my career which is going towards forty years that teachers can often be well trained in their subject area, they can be subjectary experts, they can have gone through programs but if they can't relate to kids they lose it in the classroom. We require all of our teachers to do demo lessons so we see both the teaching side of it and of course, knowledge 
of their subject area but how they relate in the classroom to kids. So those are the three most important things that I look at aside from the spiritual components as well.

GP: Mm hmm. Very good. Can you tell me a time, about a time where you felt most positive about your work as a Christian educator, a time maybe or times where your goals or values in Christian education were being met, kind of hit on the bull's eye so to speak?

JW: Well, there's all kinds of stories you know. It's fun when alumni's, alumni come back you know, they've being, as an administrators I, we're various hats, one of which is that, being ultimate level, I at times have to expel students from my school for various reasons and so forth. And in some cases we have allowed kids to come back and have a second chance. And there's been stories like that where we've had kids come back and have made big changes in their lives and it seems, have seen the light so to speak and have turned it around and those are always very, very gratifying to me. I remember one case and a situation where I was involved with a kid and I, I worked with him through a very difficult time and at one point I should have probably pretty strong measures of discipline and I decided to show grace and work with the kid. Well this kid came back to me some years after the fact and asked me if I remembered who he was and of course, he looked like an adult at this point because it was a substantial amount of time so I really didn't really remember and then he reminded me who he was. He reminded me of the story of working with him and they had a situation where I should have probably a pretty strong disciplinary approach, I decided to show some grace and work with him because of a very difficult family situation that I knew he had conquered. And he told me what he was currently doing, he was a contractor and he was coming back to see what he could do for me because I, I'd made such an impact on his life at that particular time and he remembered, anyhow there was more to it than that but... you know those kinds of things are always impactful. You know, we have retreat programs for our kids to kind of have at various class levels and so forth trying to help kids to, you know, come together and unify and hopefully be challenged through things like that. And, you know, we have a senior retreat ever year and at our senior retreat we have, it's quite a process leading up to what we call Open Mic Night and it's a time when the kids kind of get up and kind of share with their peers things that they've gained from teachers and the school and things like that and they have been so, there have been year after year just remarkable times when the kids kind of reflect back and things that they've learned and lessons and then people that have loved them through difficult times and stuff. So those are all rewarding things.

GP: That's good to hear. Are there specific situations, people, or events that have helped to really shape the way that you view Christian education? People, events that just stand out above others?

JW: I, um, have been in administration for a long period of time and there was a time when I would say that our school and the schools that I led were pretty standard in their approaches to how they charged parents and you know, how they, you know, how we ran the school administratively and back in the early 80s I was uh, I went to a conference that Bruce Lockerbie led...

GP: Mm hmm. 
JW: ... and he is out of the Stony Brook school in New York and uh, developed an organization called, Pipe Down. Have you heard of it?

GP: Yes, actually I had the fortune to interview Bruce as one of my first interviewees for this thesis so... [Chuckles] he's...

JW: So Bruce and I go way back and I would say that Bruce had as much of an impact on my thinking in terms of school management of anybody that's touched my life and to a large extent, Oaks Christian, which I founded, I'm the founding headmaster, and uh, we developed the school and the startup gift that started our school was very significant and enabled us to do some pretty amazing things developing the school. But the philosophy behind how we set up the school, a lot of it I guess goes back to what I learned through Bruce from many, many years and I've done some work with Bruce over the years.

GP: That's great. And, uh, are there a few specific things that really rise to the top when you think of the philosophies you learned from Bruce, or...?

JW: Well, one is a very practical one and that has to do with the way you charge tuition for your school. That, the vast majority of ACSI type schools have a philosophy that you charge as low as you can to encourage more people to come to your school that can, so it's much, more affordable, at least that's the theory. But if you look around, we're in a pretty tight economy right now and ACSI schools are at, the average ACSI School is losing enrollment and they're struggling financially and there's a lot of schools that are closing down, Christian schools that are closing down. And, the flaw in that thinking is that they charge on the margin and then hope that they can raise the money through candy sales and other things to make the difference and it's just the whole fundamental philosophy of that approach is flawed as opposed to the independent school model. The independent school world affiliated with the National Association of Independent Schools in California are a local association of California Association of Independent Schools, to me they're from a purely academic standpoint finest schools in this country and they typically charge pretty high tuitions and then they have financial need programs to help bring about the objective many of these schools have for socio-economic diversity around, like diversity in their schools. What we do at Oaks Christian emulates the independent school world, in other words we charge what it costs to operate for excellence, we pay salaries equal to or above public school salaries, we have good benefits programs, we have professional development programs that are outstanding, small class sizes, you know, the typical formulas for schools of excellence. But, you charge for what it costs and then you give, what we call needs based, mission driven financial aid. Needs based means it's all based on need but we don't scholarship people because they're great athletes or this or that but its needs based, mission driven. Mission driven meaning, "What are the distinctive that you're gonna bring to Oaks Christian to help us drive the mission of the school?" And as I've quoted, there's three pillars to that: academic excellence, artistic expression, and athletic distinction. So, we look for kids that have need, financial need that can bring elements that help support the schools mission. So, I guess from an overall answer to your question, we had, one of the simple things that I learned is that charge what it takes to create excellence, give needs based financial aid to those that can't afford it rather than blanketly lowering your tuition cost and thereby giving financial aid to everybody respectable for then, if 
they need it or not. I mean, it just doesn't make sense. Oaks Christian is now in its eleventh year, we've grown solidly every year since our beginning. We're just going through the admission cycle for next year and we're, we're gonna grow again. Our capacity will be 1500, 500 in our middle school and 1,000 in our high school and we think we'll hit that in about two years down the road. We should be over 1400 next year.

GP: That's good to hear. Jeff, you've mentioned a bit about your methods and the things that you feel most passionate about in the school that you run there. How could your methods for adapting this type of 21st century Christian school be brought to the minds and methodologies of other Christian school educators, like myself or others?

JW: Well, obviously through conferences I guess, through you know, we have a lot of people that visit Oaks Christian for example and we're willing to share. And Oaks isn't the only good school out there, there's a lot of good schools out there. There's schools like Oaks that have sprung up all over the country and then, they're doing great stuff. But it, it's the idea of, of the pursuit of excellence and not just in name only but in word and deed and facilities and everything. And uh, you know I think gathering a consortium of like-minded people together there. Who is the superintendent of Wheaton Academy over at... great book, I forget the exact title of it but, you know, "Best Practices for Top Schools". You know, I don't know exactly his title.

GP: Mm hmm.

JW: But I think through consortiums like that, through conferences, Odeon offers a conference every year. You know through visitations I think, you know, I've been impressed with a lot of Christian school educators that are out actually looking at others and they wanna do well and so they wanna emulate schools that are, have a good reputation, they're doing well and so sharing of those kind of things. So you know, all of the above I guess.

GP: Okay. Well we've talked quite a bit about just philosophy from the administrators stand point as well as some things with teachers and students, what role do you see parents needing to play in the 21st century Christian school, if you could boil it down to a few key points?

JW: Well, I think the research in education does indicate that when parents are involved in their kids' education, kids do better and they're higher, there's more motivation. So, I think look for ways to partner with parents, I think you know, it's important to have you know parent education series every now and then where you have seminars and opportunities to educate parents on things that you feel are important to the school and as partners. So those kinds of opportunities are important. I think look for ways to get them involved in the day to day process with kids. You know, we have volunteers all over our school from the cafeteria to the library to you know, development, to helping in classrooms, so you know, involving parents as much as possible and I think a lot of parents like to get involved. There's some that can't because they work and that's understandable but you know, look for ways to partner with parents. And then you know one that shouldn't be overlooked is just communicate. I think it's important to send team messages to parents at home. We have a weekly email newsletter that we 
distribute it by email, we've decided, we've moved away from sending out hard copy newsletters anymore trying to send them, to devices to tell them, you know, people's smart phones as well as they're emails and that kind of thing. So, just strong communication so, yeah, involvement, parent seminars, communications and volunteer opportunities, so yes.

GP: That's great. Well thanks for talking to me today, I know you've graciously answered many questions here; I just have one further for you that might help me. Are there any thoughts on the need to transform education in the 21st century Christian school that you'd like to share or books or websites that you would think might be valuable to me, moving forward?

JW: Well one of the books that I, I, that's impacted us in terms of this whole online approach is called, "Disrupting Class" by Clayton Christenson. It's basically, he has developed a theory that is applied to various types of businesses called his "Disruptive Theory" and the idea of, of that is that there's certain elements that seem to come together and in this particular case with the sophistication of technology and the ease of how it's transmitted and the devices upon which it, it's set, utilized over time has gotten to the point where the elements for what it takes to develop good online learning type programs is all converged and so, he sees that when, his theory is that when certain elements all come together it creates what he calls, "Disruption Theory" causes disruption and so, there's a paradigm shift and things change and they can change very rapidly once this paradigm shift happens. And his theory is that the paradigm shift is changing now for the delivery of education and what education has been based on up until this point is seat time, that is time of kids in their seats in this classroom, and Florida Virtual, if I can take the acronym that they've put together is that they've because of all these things converging together, the growth of online schooling is happening rapidly and Florida Virtual has developed a theme called "Any time, Any Place, Any Path, Any Pace". When you think of those four elements, any time of day, the kid doesn't have to be in a seat during the six hour day that typical stuff they can do it morning night or whatever, they can be on the road traveling, so any time, any place, from anywhere around the world that gets technology can kind of be the device to kind of get the education going. Any path, it doesn't matter what your learning style is, you know, there's a way through online education to meet your needs and any pace, at whatever pace that you wanna put forth. It's remarkable. So there's a converging of technologies coming together with a transforming world. So I would say I guess, the answer is, that, that's, that was a profound read for me and I'm doing a lot more research in the online education world. INAECAL is a website, it's a, it's a INAECAL is the national, uh, International Online Learning Website and Organization and they have a lot of good research going so I, I guess, because of my interest of what we're doing in the online world, that's something l'd look at.

GP: Very good. Thank you. Well you've shared quite a bit, thanks for taking the time today.

JW: Yeah, good luck with your Masters program thesis, I hope it all comes together for you.

GP: Yeah, thanks so much. Well, when I put it together and it, at least the transcript or so forth, I might send one out to you just so you can see what comes about and like I said, I talked to you here toward 
the end of my interviews, I actually had the opportunity to talk to Bruce Lockerbie at the beginning, so it's kind of neat to hear you mention his name at the end of our talk here too. [Chuckles]

JW: That's great. That's great. Alright. Well, good talking to you.

GP: Alright, thanks so much, Jeff. 
